\title{
SOCIAL CHANGES AND THE GENERATIONAL DIFFERENCES IN THE FORMATION OF COLLECTIVE MEMORIES
}

\author{
Tanja Vuckovic Juros
}

Submitted to the faculty of the University Graduate School in partial fulfillment of the requirements

for the degree

Doctor of Philosophy in the Department of Sociology, Indiana University

December 2012 
Accepted by the Graduate Faculty, Indiana University, in partial fulfillment of the requirements

for the degree of

Doctor of Philosophy.

Doctoral Committee

Brian Steensland, Ph.D. (chair)

Elizabeth A. Armstrong, Ph.D.

Ognjen Čaldarović, Ph.D.

Thomas F. Gieryn, Ph.D.

December 11, 2012 
Copyright (C) 2012

Tanja Vuckovic Juros

All Rights Reserved. 
To my life partner and best friend

\section{Luka Juroš}

who was by my side every step of the way. 


\section{ACKNOWLEDGEMENTS}

This has been a long path and I am very grateful to everyone who helped me along the way. The Department of Sociology at Indiana University at Bloomington provided a challenging and supportive academic environment and formed me as a sociologist. My advisor and dissertation chair, Brian Steensland, in particular stands out as a person who inspired and challenged me and who shaped both my writing and my approach to theory. I am grateful to Brian for his infinite patience with my many delays and too wordy drafts and for his detailed and thoughtful feedback that guided me even across the ocean. The best things in this dissertation are here because Brian pushed me to do better.

I am grateful as well to other members of my dissertation committee. Elizabeth Armstrong was the first to see my developing thoughts on what will later become my dissertation topic and her encouragement for pursuing this project was invaluable. Tom Gieryn, in his first year theory course, challenged me in numerous ways and his encouragement for us to dream big sociologically is advice I always come back to and which pushes me further. Ognjen Čaldarović gave me a chance to present at an academic conference while still an undergraduate, wrote letters

of recommendation for me when I was applying for the US graduate schools, and helped my find my bearings and a place in the Croatian academic community when I got back to Croatia to do my dissertation fieldwork.

Many other people helped me both in getting to the graduate school and in finishing my dissertation, and at this place I would like to thank at least some of them. Aleksandar Štulhofer was my first role-model as a sociologist and I am grateful to him both for his letters of recommendation for the graduate school and for still fighting windmills in the Croatian academic community - I try to do my part of this fighting as well. Brian Powell was my MA thesis advisor, but he was also someone who, in many ways, helped me survive the graduate school - I always 
knew I could seek him out when I needed guidance. Siniša Zrinščak was the best boss I could ever imagine. He provided support and understanding, not to mention free time and funding for the conference travel. Without him, this dissertation still would not have been done.

I also want to thank David Heise and Tim Hallet who provided valuable comments on early drafts of my research proposal, Ivo Goldstein and Zdenko Radelić who helped me choose the critical discourse moments, Snježana Koren who provided advice and comments on the textbooks chapter, Mirela Lekić from HOK who helped me find many vocational respondents, and Nenad Fanuko who hosted me at the Cultural Studies Department in Rijeka while I was on the NZZ Fellowship. Thanks also go to the guys in the NSK basement who gracefully tolerated my presence in their workspace and who made sure I got all the newspapers I needed.

I also got many useful advice and comments on various drafts of the dissertation chapters from participants at various conferences, including “Form and Functions of Social Memories” in 2010 in Erlangen, Germany, the ESA PhD Summer School in 2012 in Lisboa, Portugal, and the ASA Annual Meeting in 2012 in Denver, Colorado. Among them, particular thanks go to Helena Carreiras, Jeffrey Olick and Sara Tomczuk. Finally, I am also grateful to the US National Science Foundation (NSF) and to the Croatian National Science Foundation (NZZ) for cofinancing my dissertation research.

Without the emotional support of my friends and family all this would have been much more difficult, if possible at all. To mention only a few, thank you, Shiri Noy, Teo Matković, Ivana Dobrotić, Karin Doolan, Marija Brajdić Vuković and all you people who patiently listened while I talked about my dissertation and kindly did not ask me too often if it was done yet. I am grateful to my Mom and Dad who found it very hard to let me go all by myself across the ocean, but who did it anyway and learned how to use Skype along the way. My sister Lana Vučković was always near at hand, whether physically or virtually, and I am very grateful for knowing I 
can always count on her. Finally, my husband Luka Juroš patiently suffered through all my anxieties and preoccupations with the dissertation, which often left him neglected, and always provided love, support and intellectual challenge. Without him, I know I never would be at this point in my life.

At the end, however, I must thank the people without whom this dissertation never could have been done, my respondents. They graciously took time out of their lives to sit with me, a stranger, and to talk to me about the communist Yugoslavia. Thank you! 
Tanja Vuckovic Juros

\section{SOCIAL CHANGES AND THE GENERATIONAL DIFFERENCES IN THE FORMATION OF COLLECTIVE MEMORIES}

The present study examined how collective memories on a recent difficult past were formed among young people coming of age in a society transitioning from a totalitarian regime through an authoritarian state to a nascent democratic society. I used textual analysis to examine the presentations of the communist Yugoslavia institutionalized in the Croatian history textbooks and newspapers in 1991-2007, and I compared them to the accounts of the Yugoslav past among the Croatian transitional (born 1978-81) and post-communist generation (born 1989-91). These two generations were distinct in their childhood and formative years' experiences of Yugoslavia and post-Yugoslav Croatia, but both depended on secondary sources such as parents, school and the media for their evaluations of the Yugoslav period.

The present study found that the textbook and newspaper presentations, primarily shaped by the 1990s nation-building elites, mainly portrayed Yugoslavia in negative political, economic and ethnic terms. However, findings from 72 in-depth interviews with the two young Croatian generations suggested that the influence of the dominant negative re-evaluations was limited, particularly among the vocationally educated individuals who were least exposed to the institutionalized presentations of the Yugoslav past. In contrast, the young Croats, independently of their differences, generally dominantly evaluated Yugoslavia in positive social terms, which was a perspective obtained from their parents and older people recounting their good lives in Yugoslavia. This perspective was appropriated not only because its sources were emotionally available and credible, but also because the social lens on Yugoslavia helped the young Croats make sense of their lives in the social insecurities of the contemporary Croatian society. 
Therefore, the present study showed how different beliefs on the Yugoslav past, available from different sources, were appropriated and used by the young Croats. I also proposed Interactional Model of Collective Memories Formation, which elaborated how the influences on the beliefs of the past were formed at the macro, micro and the level of social interaction. Finally, this study also illuminated how active actors reinterpreted the presentations of the past, thus demonstrating how individuals can use culture in diverse and adept ways.

Brian Steensland, Ph.D. (chair)

Elizabeth A. Armstrong, Ph.D.

Ognjen Čaldarović, Ph.D.

Thomas F. Gieryn, Ph.D. 


\section{TABLE OF CONTENTS}

Chapter 1: Remembering Yugoslavia in the Post-communist Croatia and Theoretical and Methodological Framework for Studying Collective Memories............................................... 1

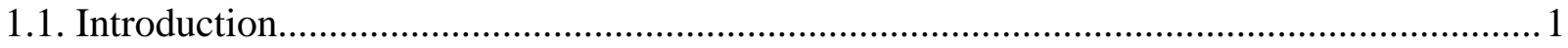

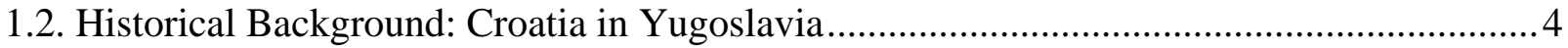

1.3. Studying Collective Memories: Development of the Field and Conceptualizations of

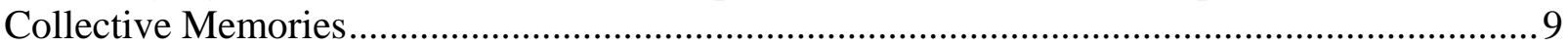

1.4. Methodological Framework for Studying Collective Memories ..................................... 15

1.5. Issues in Research of Collective Memories................................................................... 23

Chapter 2: Institutionalized Memories of the Communist Yugoslavia in the post-Yugoslav Croatia: Framing Yugoslav Past in History Textbooks and Newspapers ............................. 35

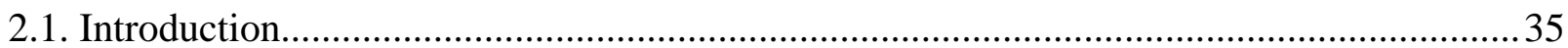

2.2. Studying Institutionalized Memories Through Educational System and the Media ...........37

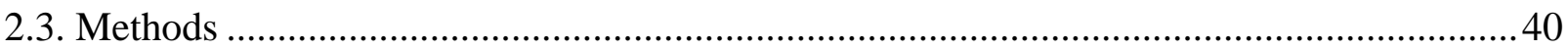

2.4. Institutionalized Frames of the Communist Yugoslavia .................................................. 45

2.4.1. Main Textbook and Newspaper Frames of Yugoslavia ............................................ 45

2.4.2. Oppositional Textbook and Newspaper Perspectives on Yugoslavia ..........................58

2.4.3. Transitional and Post-communist Generations and History Textbooks ........................60

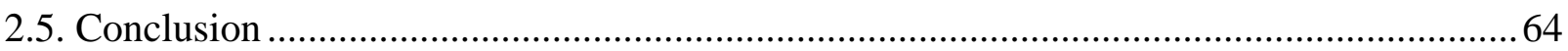

Chapter 3: Producing Collective Memories “From Above”. Uses of the Yugoslav Past in Croatian Post-Yugoslav History Education and Journalistic Discourse ............................66

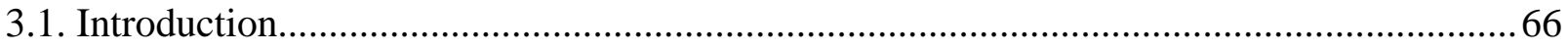

3.2. Production of Collective Memories: Role of History Textbooks and Journalistic

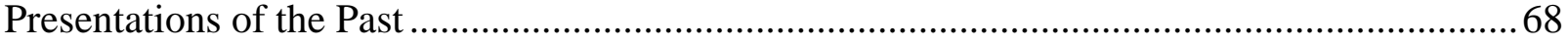

3.2.1. Uses and Malleability of the Past in Production of Collective Memories.................... 68

3.2.2. How History Education Produces Collective Memories ............................................ 75

3.2.3. How Journalists Produce Collective Memories ..................................................... 76

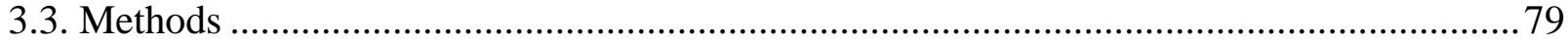

3.4. Uses of the Yugoslav Past in Educational System and the Media ....................................81

3.4.1. Influence of Historical-Institutional Context and Main Actors in the Croatian PostYugoslav Educational System and Media on Institutionalized Frames................................81

3.4.2. Journalistic Uses of the Past and Availability of Various Perspectives.....................101

3.4.3. Malleable Yugoslavia, Persisting Tito and Failed Institutionalizations ....................107

3.5. Conclusion

Chapter 4: Reception of Collective Memories and Interpretive Communities of the Yugoslav Past among Two Croatian Generations 
4.1. Introduction: Individual Approaches to Collective Memories ......................................121

4.2. Reception of Collective Memories and Interpretive Communities ............................... 125

4.2.1. Generations as Interpretive Communities of Memory ............................................125

4.2.2. Education and Remembering the Mediated Past....................................................130

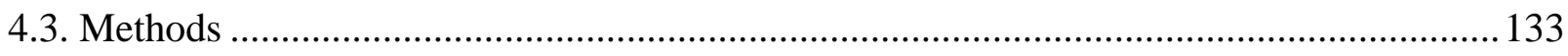

4.4. Individual Frames of the Communist Yugoslavia ........................................................ 135

4.4.1. Main Frames of Yugoslavia among two Croatian post-Yugoslav Generations .........135

4.4.2. Generational and Educational Differences in (Aggregate) Individual Frames .........148

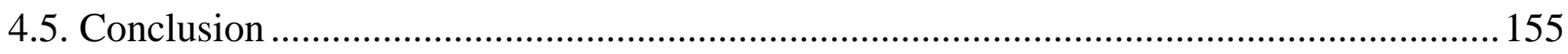

Chapter 5: Repertoires of Collective Memories and Making Sense of the Yugoslav Past..157

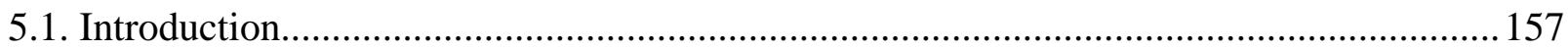

5.2. Repertoires of Collective Memories and Mnemonic Communities ...............................158

5.2.1. Repertoires of Collective Memories .......................................................................158

5.2.2. Competing Sources of Repertoires of Collective Memories .....................................161

5.2.3. What are Appropriated Collective Memories Used For?........................................165

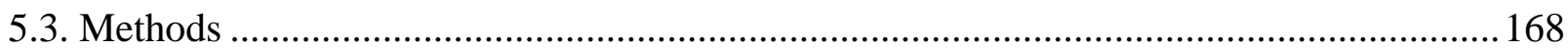

5.4. Repertoires, Their Sources and Uses of the Yugoslav Past..........................................169

5.4.1. Repertoires of Frames on the Communist Yugoslavia.............................................169

5.4.2. Competing Sources of Memories on the Communist Yugoslavia ...............................171

5.4.3. Credibility of Sources and Appropriation of Frames on Yugoslavia ........................181

5.4.4. Uses of Appropriated Frames on Yugoslavia .......................................................186

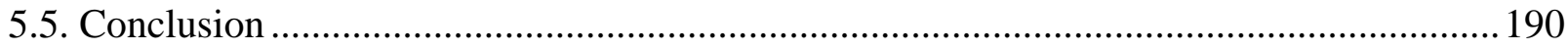

Chapter 6: Conclusion .......................................................................................................194

6.1. Main Findings and Interactional Model of Collective Memories Formation...................194

6.2. Issues in Collective Memories Research Re-Visited...................................................202

6.3. Research of Collective Memories as Part of Sociology of Culture ...............................208

Methodological Appendix..........................................................................................................215

Appendix A: History Textbooks Used in the Analysis ..................................................224

Appendix B: Critical Discourse Moments in 1991-2007 .................................................2229

Appendix C: Meta-frames and Frames on Yugoslavia in History Textbooks, Newspapers and

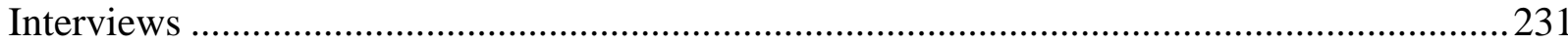

Appendix D: List of Respondents and Their Characteristics ............................................240

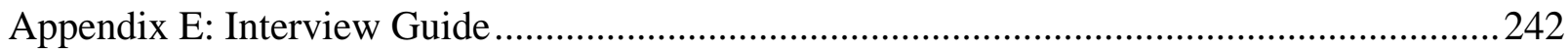

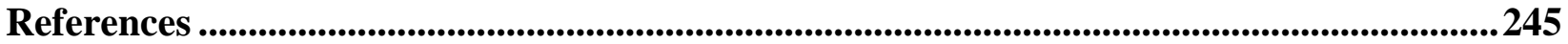




\section{Tables}

\section{TABLES AND FIGURES}

Table 2.1: Dominant Negative Political and Economic Re-Evaluations of Yugoslavia .48

Table 2.2: Repressiveness of the Yugoslav System .....................................................................50

Table 2.3: Ethnic Perspective on Yugoslavia.........................................................................52

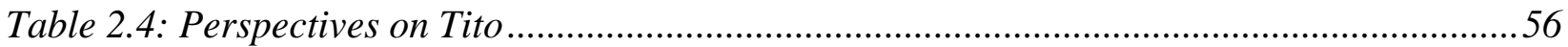

Table 2.5: Oppositional and the Minority Positive Textbook and Newspaper Frames ................6 60

Table 2.6: Meta-frames Available to Two Generations in the $8^{\text {th }}$ grade of the Primary School ... 62

Table 3.1: Lessons on the Communist Yugoslavia in the 1992 Perić's 8th Grade Textbook ........85

Table 3.2: Equivalent Excerpts from Three History Textbooks in the 1990s ..............................87

Table 3.3: Equivalent Excerpts from Three Vocational History Textbooks in the 1990s ..............88

Table 3.4: Articles in the Critical Discourse Moments, all newspapers....................................92

Table 4.1: Sample of the Interview Respondents .................................................................133

Table 4.2: Educational and Class Backgrounds of the Interview Respondents $(N=72) \ldots . . . . . . . . .134$

\section{Figures}

Figure 1.1: Interactional Model of Collective Memories Formation ......................................... 16

Figure 6.1: Application of Interactional Model of Collective Memories Formation .................199 


\section{EPIGRAPH}

It's gone, the 2008 song by the Croatian hip-hop band "Elemental"

Reproduced and translated with the permission of authors, Mirela Priselac Remi and Luka Tralić Shot.

They wore their hair long,

discovered LSD and pot

They sang about peace, with Tito they were non-aligned

On national basis, they were not divided

It was easy to talk philosophy

in a student mess,

To be a penniless artist

and a musician in-between

In a place where

things were working out all-right, where the state functioned

It was easy to be a student in the 1970s

My folks - they easily found their first job

Nobody hit the unemployment office

with a degree in their hands

The living was good in that party system

Nobody talked about Goli otok, you just changed the subject

The students with their hair long

got a degree and got a job,

got their paycheck regularly

You even could get an apartment

from the United Work

It was easy then to have big plans

To make your own nest,

to be relaxed, no tensions there

To have your spot in the company reserved, in the selfmanagement committee as well You stayed until you retired - all your life at the same desk

Everything didn't seem as a bluff, a cheap trick in those days

Nobody went hungry

They were happy in their little apartment

Secure job and a retirement fund

It was an easy decision to have us

Nothing is the same anymore, there is no secure path

There is no direct flight to the stars, to the better tomorrow

Black-and-white world from dreams is

in color now

But it's removed too far,

as if it's not there at all

It's gone now, it's gone, it's gone, it's gone

And today, times are different now

Many things changed

We've grown up, but things are still

not going our way

There are no jobs,

everybody is doing what they can

Or they sit unemployed

or they bribe to get in

Living as tenants, getting paid in cash

No security and heads full of chaos

It's a prize today to have a real job

With a retirement fund and benefits

This is gone today, times are different

And we couldn't be called a lazy generation

We would work, work so very hard

Our folks taught us that money

will not fall into our laps

The past is smiling at us with tired eyes

Air smells of nostalgia

Blato is gone, Zvečka is gone, everything is gone with the wind

At least our folks have memories

Pioneers are in the past, students are grown up

Nobody drives a red yugo anymore

Dinars are gone, workers are retired

All we have is a hope

for the day that is to come

Hope is a whore, it changed the dream

It's gone, it's gone, it's gone, it's gone 


\section{Chapter 1: Remembering Yugoslavia in the Post-communist Croatia and Theoretical and Methodological Framework for Studying Collective Memories}

\subsection{INTRODUCTION}

On 20th January 1990, just a couple of months after the fall of the Berlin Wall, the Croatian and the Slovenian delegations walked out of the 14th Congress of the League of Communists of Yugoslavia. Less than two years later, on 25th July 1991, both Yugoslav Republics declared their independence and were facing conflict with the Yugoslav People's Army (JNA). In Slovenia the conflict lasted for only ten days, but it hurled Croatia into a war which would last until 1995, and which would soon spread to the neighboring BosniaHerzegovina. A decade after death of its founding father and President-for-life, Josip Broz Tito, the Socialist Federal Republic of Yugoslavia (SFRJ), the country with six republics, five languages, four nations, three religions, two alphabets and one party, was dead.

The past of Yugoslavia, however, is far from dead. Today, more than 20 years after its dissolution, Yugoslavia still incites heated debate in all former Yugoslav societies. Moreover, grievances inherited not only from the communist Yugoslavia, but also from the more distant past of the region are still contested by various groups, both within and across the border. Such a solid and strong presence of the past in the present is not an uncommon phenomenon, nor is it specific to former Yugoslav societies. Examples abound from all parts of the world. For instance, the Orangemen Walks in the Northern Ireland still, more than three centuries after William of Orange’s victory which they commemorate, raise tensions between the Irish Protestants and Catholics. Likewise, defeat of the Confederate forces in the US civil war is still vivid and deplored in some parts of the US South. In an example from another part of the world, relations among Japan, China and Korea are still strained because of the events of the Second World War (Kim and Schwartz 2010). 
Why do the debates about the past evoke such passion? Why does not the past remain, well, in the past? One explanation is that perceptions of a group’s past are important for its cohesion. Perceptions of the past are not idiosyncratic thought processes, but they are socially shaped and shared across a group (Zerubavel 1997). Therefore, they become collective memories which include not only collective imaginings of the past, but also implicit assumptions and interpretations of the present and the ideas about the desired path for the future (Schwartz 1996b). This makes consensus on the past a part of intersubjectivity among individuals, which makes social order possible (Mead 1934). Therefore, breaches of intersubjectivity threaten social order and for this reason they evoke such strong emotional reactions (Garfinkel 1964). As a result, consensus about the past shapes social solidarity and, thus, it binds people together. But, disagreements about the past can fuel conflict and thus serve as a disintegrative factor. Challenging certain narratives of the past is more than just challenging certain interpretations of historical facts. It is the challenge to social order assumed by that collective memory. And this is a moral breach.

The history of former Yugoslavia had certainly proven true this power of collective memories. Grievances fueling conflicts that more than a century ago had given the region its unfortunate nickname of Europe’s “powder keg” are such grievances of “long memory”. Even the 1990s wars of the Yugoslav secession, with their unenviable title of the bloodiest conflict in Europe since World War Two, were incited by yet another rehashing of the long-gone past, which was supposedly repeated or perpetuated in the communist Yugoslavia. Moreover, the period of the communist Yugoslavia has today become another such restless past that raises heated emotion even among new generations in the Croatian society, the young people who were coming of age or who were born after the Yugoslav break-up. 
The new Croatian generations, who are carriers of collective memories of Yugoslavia in their full sense of not personally, but socially experienced memories (Halbwachs 1992 [1952]; Zerubavel 1996), are of focal interest in the present study. Moreover, these young people witnessed construction of collective memories on Yugoslavia. The Yugoslav past for them is not just a straightforward or simplified historical story they read about in history textbooks, as some future generations might. Instead, thinking of the Yugoslav past means confronting competing perspectives, both in public discourse and among people who lived through this period.

Furthermore, the Yugoslav past in the post-communist Croatia was remembered in context of a relatively quick succession of two regimes with different stances towards Yugoslavia. First, Croatia in the 1990s was ruled by a nationalist government headed by autocratic Franjo Tudjman who sought to affirm legitimacy of the new regime in opposition to Yugoslavia. This authoritarian period ended with Tudjman's death in 1999. The regime change in 2000 marked a new period of liberalization and democratization, which potentially opened up discourse on Yugoslavia. Young Croats formed their perspectives on the Yugoslav past in such a changing social context.

Therefore, a study of how collective memories on the communist Yugoslavia were formed among the young Croats provides a unique opportunity for examining intersections of various influences, both institutional and interpersonal, on formation of personal beliefs about the past. I specifically examine memories of two generations of young Croats. One generation, the transitional generation (born 1978-81), spent its early childhood in Yugoslavia and its adolescence and early adulthood in the authoritarian post-communist Croatia. The other generation, the post-communist generation (born 1989-91), was born after the break-up, but it spent its formative years in democratizing post-Yugoslav period.

Both these generations were hardly able to form mature meaningful evaluations of the past. 
Rather, for their images of Yugoslavia, they were often dependent on family experiences and on public discourse. However, these generations differed in their educational paths ${ }^{1}$ and they differed in their formative years' experiences of public discourse on Yugoslavia. These key different experiences justify assumption that these two groups are more than just different birth cohorts, but that they indeed form two distinct generations (Mannheim 1952) and, as such, they may form different communities of memory on Yugoslavia.

Therefore, the present study examines how different beliefs about the Yugoslav past gained standing among these two generations, and how these beliefs were mediated by the generations' formative experiences, family histories and public discourse. In the rest of the chapter, I first present a short and necessarily simplified Croatian history in Yugoslavia. Then I present this study's theoretical and methodological framework.

\subsection{HISTORICAL BACKGROUND: CROATIA IN YUGOSLAVIA}

The former Yugoslavia area is usually considered to be on crossroads of different civilizational influences. Croatia's position specifically is often seen as between the East and the West: “for Croatia has long been placed on both sides of important historical and geographical divides: classified as both Byzantine and Catholic, Ottoman and Austro-Hungarian, Eastern and Western, Balkan and European” (Razsa and Lindstrom 2004:648).

Until the end of the First World War, Croatia was a part of the Habsburg Empire. In 1918, together with Slovenia, and the territory later to become Bosnia-Herzegovina, Croatia joined with the Kingdom of Serbia (at that time including the territory of Macedonia) and the Kingdom of Montenegro into the newly founded Kingdom of Serbs, Croats and Slovenes, presided by the Serbian royal family of Karadjordjevic. The new state was characterized by repressive policies

\footnotetext{
${ }^{1}$ The transitional generation started its education in the Yugoslav system and finished it during the 1990s authoritarian period, whereas the post-communist generation was educated in the democratizing 2000s.
} 
and the dominance of Serbia. This was consolidated in 1929 when King Alexander, who was to be assassinated five years later, proclaimed a royal dictatorship and the state was renamed into the Kingdom of Yugoslavia (Ramet 2006; Goldstein 2008).

In 1941 the Kingdom of Yugoslavia was invaded by German forces. In a matter of a few days the Kingdom surrendered, and the Yugoslav territory was divided among Germany, Italy, Hungary and Bulgaria (by direct annexation of the territory or by establishment of a military administration). This also resulted in the creation of the so-called Independent State of Croatia (NDH - Nezavisna Država Hrvatska) headed by a puppet fascist government of the so-called Ustasha (Ramet 2006). However, both the Nazi forces and the Ustasha were opposed by an underground Communist resistance movement of the so-called Partisans led by Josip Broz Tito. In 1943 Tito and the Partisans proclaimed the Democratic Federation of Yugoslavia. After the war, this state was renamed into the Federal People’s Republic of Yugoslavia. It consisted of six Republics $^{2}$ that constituted the communist Yugoslavia (renamed into the Socialist Federal Republic of Yugoslavia /SFRJ/ in 1963) until its disintegration in 1991.

The second Yugoslavia started out as a state close to Stalin's USSR, but this soon changed. In 1948 Tito and the Communist Party broke all relations with the USSR, which was followed by a major role of Yugoslavia in the establishment of the Non-Aligned Movement in the early 1950s. Although relations with the USSR would improve after Stalin's death, Yugoslav foreign policy remained consciously at a distance from both the European East and the West (Ramet 2006; Goldstein 2008). Economically, the post-war years were a struggling period for Yugoslavia, but one soon rewarded by periods of economic growth. In particular, after the break with the USSR, Yugoslav economy was boosted by loans from the West.

\footnotetext{
${ }^{2}$ Slovenia, Croatia, Bosnia-Herzegovina, Serbia (with the autonomous provinces Voivodina and Kosovo), Montenegro and Macedonia.
} 
Further, after the economic reforms in the early 1960s, living standards of the Yugoslav people improved and, during that period and particularly in the 1970s, the Yugoslavians started developing new consumerist behavior, such as going shopping into the neighboring countries (most often Austria and Italy) or building weekend houses (Ramet 2006; Goldstein 2008). However, in this period the economic gap between the Yugoslav Republics started widening, since it was Slovenia and Croatia that experienced the highest economic growth, while other Republics lagged behind. Despite Tito's attempts to create a unified Yugoslavia, a federal arrangement of the state and the fact that ruling elites in each of the Republics saw themselves as representatives of their own nation, while ethnicity was officially a non-issue, led to the growing political separation of the Republics which would come to the fore in the economic crises in the 1980s (Sekulić 2004).

In the late 1960s, Yugoslavia experienced a limited political liberalization (Goldstein 2008). In this atmosphere, certain groups started raising some previously prohibited questions about national inequalities, particularly in area of culture and language (Goldstein 2008). Such questions in Croatia culminated in the publication of the Declaration on the Status and Name of the Croatian Literary Language in 1967, protesting the perceived inequality of the Croatian language. The Declaration was officially condemned for endangering Yugoslav "brotherhood and unity”, and many of its signees were sanctioned or even removed from public life. Nevertheless, these events were a prelude to emergence of the Croatian Spring mass movement (Goldstein 2008). The Croatian Spring movement had a twofold character. On the one hand, it was a movement for democratization and greater economic liberalization led by progressive members of the Croatian Communist government. On the other hand, this movement was also intertwined with the Croatian nationalist upsurge, which sprang as a reaction to the perceived 
threat of Serbian supremacy and the suppression of the Croatian language and culture in Yugoslavia (Ramet 2006; Goldstein 2008).

The movement reached its peak in 1971 when the Croatian Communist leadership was forced to resign, thus provoking student demonstrations in Croatia's capital Zagreb. This was followed by massive purge of the Croatian Communist Party, numerous arrests, a wave of political emigration and widespread police repression and banning of any kind of activity that could be construed as nationalistic (Ramet 2006; Goldstein 2008). Furthermore, after suppression of the Croatian Spring, the Croatian political scene fell into an apathy that would last well into the next decade (Goldstein 2008).

However, the failed 1960s/1970s movements had one important consequence - the new 1974 Constitution increased sovereignty of the Yugoslav republics and the autonomous provinces Voivodina and Kosovo (Goldstein 2008). In the 1980s, greater rights accorded to the autonomous provinces led to increased dissatisfaction in Serbia, and the rights accorded to the Republics served Croatia and Slovenia as a legal basis for secession from Yugoslavia.

With death of Josip Broz Tito in 1980, Yugoslavia lost its undisputed central point of authority and the Republics increasingly ran into difficulties in reaching any kind of consensus on political and economic matters (Goldstein 2008). Moreover, the Yugoslav socialist economy started showing cracks and the failing economy was further burdened with international debt of previous periods coming due. In this context of economic crisis, each Republic perceived its position in Yugoslavia to be one of exploitation, although for different reasons. For example, the Western republics Croatia and Slovenia believed that too much of their capital was going to the underdeveloped republics, whereas Serbia believed they were exploited as a big market for expensive products of the Western republics (Goldstein 2008). 
Nationalist movements also started rising in all Republics. In Croatia, voices from the nationalist movement that went underground after the failure of the Croatian Spring were becoming stronger. In Serbia, there was a growing dissatisfaction with greater sovereignty which the 1974 Constitution gave to the autonomous provinces, particularly as the majority Albanian population at Kosovo increasingly demanded more autonomy and even secession. As a result, the claims about exploitation of Serbia in Yugoslavia and endangered position of the Serbs living in other Republics started gaining ground in public discourse. In this context, a fiercely nationalistic and populist Slobodan Milošević came to power in 1987 (Ramet 2006; Goldstein 2008). As Ramet sums up, “tensions in Kosovo provided the grist for Milošević's rise to power in Serbia, provoked a dramatic showdown between Slovenia and Serbia over the place of the autonomous provinces in the federation, provided the backdrop for a general deterioration in relations between Serbia and the other republics, and fueled rising Serbian nationalism, which in turn infected Serbs in Croatia, leading to renewed difficulties in Croatia” (2006:306).

At the same time, Yugoslavia experienced changes that destabilized other Central and Eastern European communist regimes. The public sphere’s growing liberalization increasingly eroded the Communist Party’s legitimacy. In 1988/1989 initiatives for the formation of oppositional parties emerged in Croatia. At the beginning of 1990 all such parties were legitimized and soon stage was set for organization of the first multiparty elections (Goldstein 2008). However, before the elections were to take place, the Yugoslav republics had a final falling out at the 14th Congress of the League of Communists, where Slovenia and Croatia on one side and Serbia on the other side collided over Yugoslav centralization. The Congress was dismissed when the Slovenian and the Croatian delegations left in protest.

The first multiparty elections in Croatia, following the failed congress by a few months, 
resulted in an overwhelming victory of the nationalist Croatian Democratic Party (Hrvatska demokratska zajednica - HDZ) headed by Franjo Tudjman. In the referendum held less than a year later, more than $90 \%$ of Croatian citizens voted for independence. A few months afterwards, in July 1991, both the Croatian and the Slovenian parliament proclaimed independence from Yugoslavia (Goldstein 2008). Officially, Yugoslavia ended and the wars of the Yugoslav secession were just about to start. With this, the Croatian post-Yugoslav period begins and Yugoslavia becomes matter of collective memories.

\subsection{STUDYING COLLECTIVE MEMORIES: DEVELOPMENT OF THE FIELD AND CONCEPTUALIZATIONS OF COLLECTIVE MEMORIES}

“Collective memories” is one of those multivalent concepts, like culture, that cause disagreements and debate about their proper meaning and use. Such debates are further exacerbated by interdisciplinarity - and sometimes the interdisciplinary lack of communication characterizing this field (Erll 2008). Collective memories are thus studied in disciplines from sociology and history to psychology and literary studies. Many scholars in these disciplines conceptualize collective memories differently. Moreover, many use different terms when referring to this concept. In addition to collective memory/memories (singular or plural), some terms used most often are social memories, cultural memories, public memories and collective remembering (Olick 1999; Fentress and Wickham 1992; Olick, Vinitzky-Seroussi, and Levy 2011; Erll 2008; Hamilton and Shopes 2008).

Furthermore, many of these different approaches reflect a dichotomy between collectivistic conceptualizations of collective memories, focusing on material embodiments of memories, and individualistic conceptualizations, focusing on individuals as carriers of memories (Olick 1999). Both these approaches can be traced back to the early-20th-century French sociologist Maurice Halbwachs, who is today generally considered a founding father of the collective memories field. 
Durkheim’s student Halbwachs (1992 [1952]) conceptualized collective memories as the collectively shared representations of the past that are appropriated from the present perspective. Halbwachs built on Durkheim's work on collective representations and on Durkheim's interest in link between rituals and group solidarity (Coser 1992; Misztal 2003a). Thus, for Halbwachs, collective memories are embodied in memory sites and objects which transmit the collective effervescence of intense rituals into everyday life, thus keeping the bonds between people strong even in the "profane" periods (Coser 1992).

As a result, Halbwachs’ research (1992 [1952]) focused on embodied collective memories, such as the memory sites of the Holy Land. This work, then, can be seen as a precursor of the studies of (collectivistic) collective memories as the objects, sites and rituals of memory (see, for example, Nora 1996b). At the same time, in his theoretical considerations of collective memories, Halbwachs (1992 [1952]) emphasizes that, ultimately, it is individuals who remember. They do it within social frameworks, as members of social groups, but still, memories are located in human minds. This work, then, can be linked to individualistic conceptualizations of collective memories (see, for example, Schuman and Scott 1989).

A common narrative on history of the collective memories field identifies a great gap between the work of Halbwachs and some of his contemporaries (such as Marc Bloch, Andy Warburg and Frederic Bartlett) in the early 20th century and the resurgence of interest in collective memories in the 1980s (Olick and Robbins 1998; Olick et al. 2011). However, many contributions to the field were scattered among scholars working during the "gap period" (Olick et al. 2011). Nevertheless, both the scope of interest in collective memories as a social phenomenon and the deliberate and the self-conscious development of the academic field were unprecedented before the 1980s. Therefore, this period deserves its label as the period of the 
“memory boom” in social sciences (Klein 2000; Schwartz and Schuman 2005).

One of perhaps key contributions in the emerging collective memories field was Pierre Nora's monumental seven-volume work Les Lieux de mémoire (1984-1992), in which he and his colleagues documented the "symbolic objects" of French memory, such as the archives, libraries, dictionaries, museums, commemorations or celebrations (Nora 1989:12). Nora's work, which quickly became influential outside the French borders, continued Halbwachs' interest in "sites of memory” (Erll 2008). Further, in this period German Egyptologist Jan Assmann also published his studies on forms of memory in ancient societies, and in the 1990s he and his wife Aleida Assmann further developed concept of "cultural memory” (Erll 2008). This concept also continued with the collectivistic strand of Halbwachs' work - "cultural memory" primarily referred to the culturally institutionalized "figures of memory" (Assmann 1995).

Both Nora and Assmann acknowledged the individual dimension of collective memories. Assmann (1995), for example, specified that collective memory consisted of two elements: cultural and communicative memory, where the latter refers to the dimension of memory carried by individuals and transmitted through social interaction. Likewise, Nora (1989) cited Halbwachs saying that memories were group-specific, and also collective and individual simultaneously. Nevertheless, in their own research, both these authors - similar to Halbwachs focused on collectivistic or institutionalized dimension of memories. Both Nora and Assmann were very influential among European scholars of memory (see, for example, Erll 2008). Many of these authors, therefore, continued with this vein of semiotic-philosophical-historical research, examining collective memories in their embodied forms which existed independently from individuals, such as monuments, museums, texts, memorials, commemorative rituals and similar sites of memory (Nora 1996a; Assmann 1995). 
After the first English translation of Halbwachs in 1980 and particularly after Coser’s translation in 1991, Halbwachs' ideas started influencing US memory scholars (Schwartz 1996a; Schwartz and Schuman 2005; Olick et al. 2011). US sociologists, however, were more interested in processes producing the sites, texts and rituals of memory than in their forms and content. Thus they examined, for example, how political elites influenced commemorations (see, for example, Schwartz 1982) or how the media shaped public discourse on the past (see, for example, Schudson 1992). Nevertheless, similarly to European authors, this work also primarily examined the collectivistic dimension of memory: “emphasizing only 'sites' of memory and their cultural meanings” (Schwartz and Schuman 2005:183).

In fact, Schwartz and Schuman (2005) label both the work of authors such as Nora and the main developments in the US memory research since the 1980s as the "new structural memory". The particular strength of such structural approaches to collective memories lies in their ability to examine socio-structural conditions in which various types and forms of memories are constructed and to identify how various actors, from political elites to journalists, contribute to institutionalizations of particular presentations of the past.

However, some recent works have pointed out that structural approaches face challenges when they need to explain how competing memories gain standing or how some memories fail to achieve legitimacy (Schwartz and Schuman 2005; Kansteiner 2002). For example, Kansteiner (2002) criticizes the structural approaches to collective memories for not paying sufficient attention to active and possibly subversive interpretations of the from-above presentations of the past by “memory consumers”. Likewise, Schwartz and Schuman (2005) call for inclusion of individual beliefs into the study of collective memory, and for examination of how individuals may reinterpret presentations of the past institutionalized in history texts and commemorative 
symbols. From a different perspective, Fine and Beim (2007) also note incompleteness of structural approaches, particularly their tendency to reify collective memories and neglect level of social interaction, which, in their opinion, is the level at which collective memory is formed. All these criticisms, therefore, suggest that the structural approach to collective memories should be complemented by individual approach, which, then, brings individualistic dimension - or the socially-framed individual remembering (Halbwachs 1992 [1952]) - into the study of collective memories.

Nevertheless, when considering how to include individuals into the study of collective memories, the key point is that collective remembering may happen in individual minds, but it is a social process. Individuals do not remember the collective past in isolation, but they do it as members of social groups, following social rules of remembrance (Zerubavel 1996). Consequently, collective memories cannot be predicted from individual recollections (Olick 1999; Kansteiner 2002) as they have their internal rules of organization which result in supraindividual forms of remembering and forgetting (Zerubavel 1996, 2004). Several authors, therefore, conceptualized collective memories by emphasizing their intersubjective character.

Olick thus suggests that the dichotomy between individualistic and collectivistic conceptualizations of collective memories reflects the dichotomy between the view of "culture as a subjective category of meanings contained in people's minds versus one that sees culture as patterns of publicly available symbols objectified in society” (1999:336). These two opposed views are reconciled by regarding culture as intersubjective, which should also work for collective memories (Olick 1999). Therefore, in Olick’s view, collective memories, like culture, are intersubjective, but embodied in "symbolism and patterns of meaning” (1999:337).

Misztal approaches collective memories in a similar manner. She believes that (1) 
individuals remember, (2) individual remembering is shaped by what is shared by others, and (3) collective memory is memory of the intersubjective past (2003b:6). Therefore, conceptualizations of collective memories should incorporate their individual and their social dimension, which means treating collective memories as intersubjective (Misztal 2003b).

Finally, Schwartz and Schuman (2005) argue that collective memories are formed in socially-patterned interactions of individuals with institutionalized memories (historical texts and commemorative symbolism) to which individuals attribute meanings. Therefore, Schwartz and Schuman situate collective memories at intersections of institutionalized memories and individual beliefs about the past, and they see beliefs ${ }^{3}$ as realizations of collective memories. Conceptualizing collective memories as intersubjective, then, accounts for both their formation at supra-individual level (since remembering happens within social frameworks) and for their location in individual minds (since they are manifested in individual beliefs).

Therefore, the present study approaches collective memories as intersubjective - they are formed at the supra-individual level, manifested in individual beliefs and embodied in cultural symbols. In fact, such an approach to collective memories reflects this study's underlying view of culture as intersubjective and supra-individual (DiMaggio 1997; Olick 1999). DiMaggio (1997) further argues that conceptualizations of culture as supra-individual are consistent with claims that individuals use culture as a repertoire or "toolkit” (Swidler 1986, 2000). This is also compatible with the present study's approach to collective memories. In fact, in Chapter Five, I elaborate in greater detail how individuals' beliefs about the past form their repertoires of collective memories and how they then use them for different purposes.

DiMaggio also links the view of culture as a toolkit or repertoire with research in cognitive

\footnotetext{
${ }^{3}$ This includes both beliefs of individuals producing historical texts and commemorative symbols and personal beliefs of individuals consuming these institutionalized memories.
} 
psychology and suggests that cultural toolkits or repertoires consist of mental structures or schemata, which are "both representations of knowledge and information-processing mechanisms” (1997:269), and which are obtained in a socially patterned manner. Which of the various culturally available schemata will be utilized to guide individuals' interpretations and actions is guided by "cultural cues available in the environment" (1997:274), including cultural symbols external to individuals. Following these insights, Beim defines collective memories as "memory schemata that are located at a supraindividual level of social life and formed through social interaction” (2007:8). I adopt this definition in the present study.

\subsection{METHODOLOGICAL FRAMEWORK FOR STUDYING COLLECTIVE MEMORIES}

I approach collective memories as intersubjective phenomena. I conceptualize them as the memory schemata formed at supra-individual level, but which are manifested in individual beliefs. Hence, in operationalizing collective memories, I focus on individual beliefs about the past which, similarly to Schwartz and Schuman (2005), I consider as the units of analysis of collective memories as carried and transmitted by individuals. ${ }^{4}$ Further, I consider institutionalized or structural memories ${ }^{5}$ as symbols of collective memories. In other words, they are embodiments of presentations or perspectives on the past of groups that commissioned them or contributed to their institutionalization. Therefore, I agree with Schwartz and Schuman (2005) that institutionalized memories are better seen as the units of analysis of elite memories, although they also can be results or products of the memory-work by vernacular or non-elite groups (see Wagner-Pacifici and Schwartz 1991; Bodnar 1992).

Moreover, I agree with Beim (2007) that memory schemata are formed in social

\footnotetext{
${ }^{4}$ Thus, collective memories in my conceptualization are similar to what Assmann (1995) calls "communicative memory" or what Olick (1999) calls "collected memory".

${ }^{5}$ These are texts, monuments, museums, commemorative rites, etc - Nora’s (1989) “lieux de mémoire”, Assmann's (1995) “cultural memory” or Olick's (2008) “mnemonic products”.
} 
interaction, which includes both interaction of individuals within their social groups (e.g. family, ethnic community...) and interaction between individuals and institutions of their everyday lives (e.g. school). However, while Beim is primarily interested in social interaction between individuals, in the present study I focus on interaction of different institutional levels that affect individuals' formation of personal beliefs about the past. Therefore, I propose an Interactional Model of Collective Memories Formation (see Figure 1.1) which suggests that influences on individual beliefs of the past include three levels: (1) the macro level of public presentations of the past (institutionalized, for instance, in history textbooks and journalistic discourse), (2) the interactional level of mnemonic communities (Zerubavel 1997), and (3) the micro level of personal experiences that may influence beliefs about the past.

Figure 1.1: Interactional Model of Collective Memories Formation

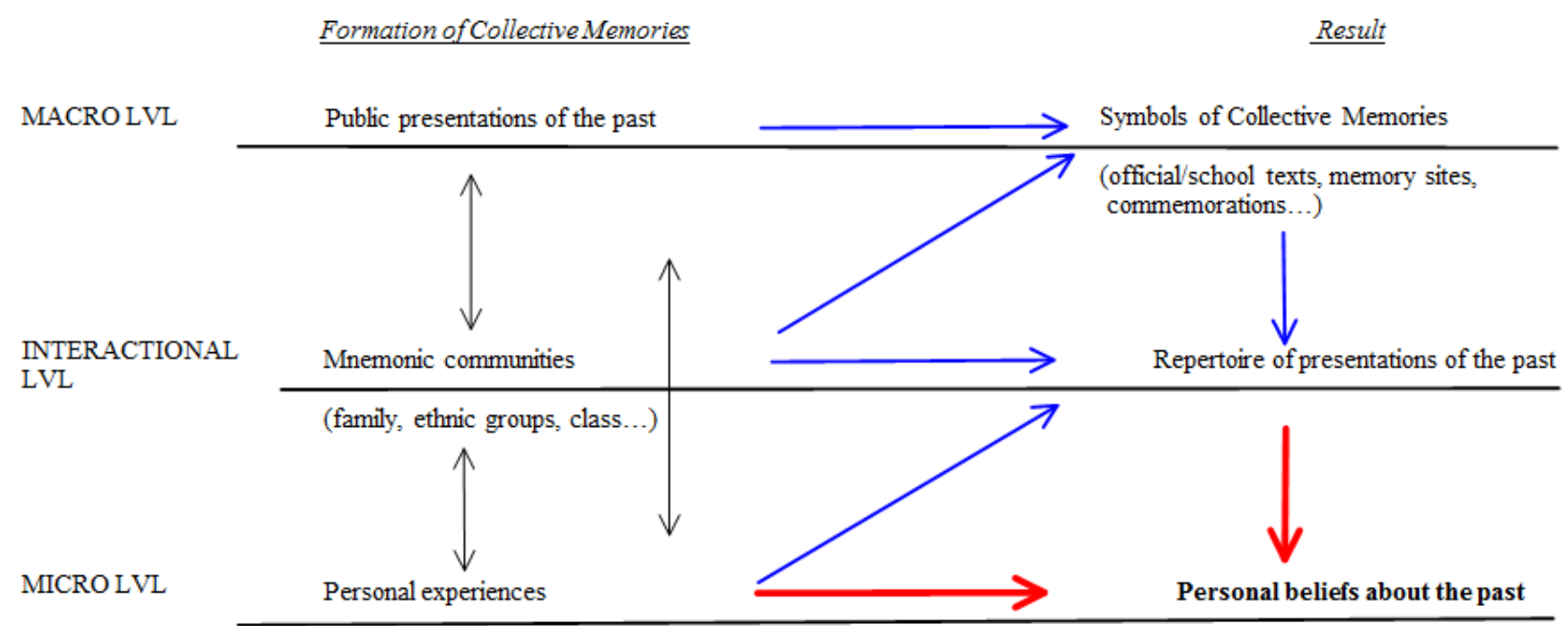

Macro level is the level of the "from above" influences that result in symbols or products of collective memories. These are structural or institutionalized memories such as history textbooks, museums, commemorative rituals and other publicly available memories. Political elites and the state have a privileged position in institutionalizing their perspectives on the past (Nora 1989; Gillis 1994), although non-elite groups might also influence arena of public or 
“official” remembering (Wagner-Pacifici and Schwartz 1991; Bodnar 1992; Armstrong and Crage 2006).

Therefore, in Chapter Two I examine the main presentations of the communist Yugoslavia institutionalized in Croatian history textbooks and newspapers. Then, in Chapter Three, I examine the historical-institutional context in which institutionalization of memories on the Yugoslav past occurred immediately after the dissolution of Yugoslavia, and I identify the main elite and non-elite actors contributing to the institutionalization of memories on Yugoslavia in Croatian history textbooks and newspapers. These institutionalized memories are one of elements forming individuals' repertoires of collective memories on Yugoslavia and affecting their personal beliefs about the Yugoslav past.

Micro level is the level of personal experiences, which can have a twofold effect on formation of individual beliefs about the past. First, the personal experiences act as independent sources of the presentations of the past. Research on the recall and knowledge of historical events has shown that individuals remember best and most often consider most important those historical events that occurred during their formative years (Schuman and Scott 1989; Conway 1997). However, dramatic or momentous events will also be remembered by all who experienced them, even if they were children at the time (Schuman and Corning 2000).

Second, experiences and concerns stemming from individuals’ socio-cultural locations also influence how individuals will receive publicly available memories. Specifically, socio-cultural locations contribute to individuals' specific experiences and expectations and these, in turn, shape individuals' interpretive frameworks - their “horizon of expectations” (Griswold 1994) or their “cognitive orientations” (Zerubavel 1997). In such a way, shared experiences create interpretive communities of memory characterized by shared interpretations of the past (Radway 
1984; Griswold 1987b; Zerubavel 1997; Zelizer 1993).

Therefore, in Chapter Four I examine how presentations of Yugoslavia institutionalized in Croatian textbooks and newspapers were received by two young Croatian generations, and how these young people's specific generational experiences and socio-cultural locations affected resonance and reinterpretations of the available memories on the Yugoslav past. Personal experiences, then, can (1) provide elements that become part of individuals' repertoires of the past, and (2) they can strengthen or lessen the influence or the plausibility of presentations of the past that already are part of individuals' repertoires.

Finally, in Chapter Five I also provide a limited analysis of the interactional level of the collective memories formation. This is the level at which various presentations of the past are acquired through interaction within mnemonic communities (Zerubavel 1997) or the social groups to which individuals belong and with whom they share certain perspectives on the past (from family to ethnic or other salient groups). A more comprehensive analyses of the interactional level would examine the everyday process of making sense of the past in social interactions, which would likely require an ethnographic approach to collective memories (Fine and Beim 2007; Beim 2007) or they would examine the formation of opinions on the past in face-to-face conversations (Olick 2007). This, unfortunately, is beyond the scope of the present dissertation. Instead, in Chapter Five I identify presentations of Yugoslavia individuals acquired from various sources (family, school, the media) and I examine how individuals evaluated credibility of various elements of their collective memories' repertoires and whose memories they appropriated as their own personal beliefs about the Yugoslav past.

The structure of the present dissertation follows the Model of Cultural Diamond Griswold (1994) proposed as a methodological framework for studying culture. Griswold (1994) uses the 
metaphor of cultural diamond to describe the four main points in the study of culture (cultural object, creators, recipients, social world) and six links between these four points that need to be examined for a comprehensive grasp of the cultural matters. Cultural objects or cultural products are the Geertzian publicly available symbols or the embodied culture (Griswold 1987b, 1994). Although it is possible to study cultural objects in isolation (for instance, we can approach a cultural object as a self-contained semiotic system or text, study the code underlying it, its genre characteristics, etc.), a full cultural understanding requires also examining how meanings of cultural objects were created or produced, how they were received and (re)interpreted, and how both the creation/production and the reception/consumption of cultural objects were situated in the social world/context (Griswold 1994).

In the present study, therefore, cultural objects are the presentations of the Yugoslav past institutionalized in the Croatian history textbooks and newspapers. They are presented in Chapter Two. Chapter Three analyzes the memory-work of the main actors producing the textbook and newspaper presentations of the past situated in their historical-institutional contexts. Therefore, Chapter Three examines Griswold's “production-cultural object-social world” nexus. In Chapter Four, I compare the institutionalized presentations with the individual accounts of the Yugoslav past among the young Croats, and I analyze reception of the textbook and newspaper presentations by these young people situated in their socio-cultural locations. Therefore, Chapter Four examines Griswold’s “production-reception-social world” nexus.

In Chapter Five, however, I move beyond Griswold's cultural diamond analysis and I address Swidler's question (2000) of how individuals use culture. Specifically, I examine how the young Croats appropriated presentations of the Yugoslav past. In addition, as described above, in Chapter Five I also examine how young Croats evaluated credibility of various sources 
of their memories on Yugoslavia. I use the findings of all substantive chapters in the Conclusion where I revisit the Interactional Model of Collective Memories Formation.

\section{Individual Beliefs on the Past and Reception of Collective Memories}

The approach of this dissertation, in which I operationalize collective memories as individual beliefs about the past, allows an in-depth analysis of a particular issue in the field: reception of collective memories. Several authors suggested that collective memories are actualized in reception (Irwin-Zarecka 1994; Crane 1997; Kansteiner 2002; Wertsch 2002; Linde 2009). Indeed, Kansteiner (2002) notes that many memory projects fail, and he partly attributes such failures to memory recipients who may ignore or transform meanings that political elites intended. Therefore, individuals as recipients of collective memories are active meaning-makers, able to construct their interpretations out of the available material (institutionalized memories), and “read” them in ways not intended nor anticipated by producers of these memories (Confino 1997; Kansteiner 2002; Wertsch 2002).

This idea of recipients as active meaning-makers (active audiences) who interact with the “text” (from books to the media messages) created and received in specific social contexts to construct their interpretations is well established in the reception studies spanning the disciplines of the literary theory, the sociology of literature and the communication studies (Griswold 1993; Press 1994; Radway 1984; Alasuutari 1999; Goldstein and Machor 2008; Radway 2008). It also fits well the field of collective memories. For example, Schuman and Schwartz (2005) found that individual beliefs in surveys on Lincoln carried different emphases than presentations of Lincoln dominating history textbooks. Similarly, surveys of popular opinion have shown that most people rejected Native American activists’ and academics’ revisionist work on Christopher Columbus (Schuman, Schwartz, and D’Arcy 2005). Indeed, Schuman et al. note that revisionists' 
beliefs reached only the people already open to such re-evaluations. Finally, in the recent research on reception of history textbooks in Japan, Fukuoka (2011) has shown that students evaluated - and sometimes dismissed - textbooks' narratives in light of other socio-political circumstances and alternative sources of memory.

Further, different interpretations and readings of available cultural material, including institutionalized memories, are often a function of individuals' social and cultural locations (Gray 1999; Bratich 2008; Radway 2008; Griswold, Lenaghan, and Naffziger 2011). As noted in the discussion of the micro level of the Interactional Model of Collective Memories Formation, individuals' socio-cultural locations shape their experiences and particular concerns, which then influence their reception and interpretations - by this, they create interpretive communities of memory.

In designing the present study, therefore, I am particularly indebted to two authors, Howard Schuman and Barry Schwartz, who in two different ways worked to bring individual beliefs and reception into the study of collective memories. Schwartz's main contribution is his work on historical reputations (mainly of Abraham Lincoln) in which he examines how ordinary Americans think and feel about historical figures by comparing the memories institutionalized in historical accounts and commemorations with trends in national surveys (see, for example, Schwartz 1998, 2011). Schuman, together with his various colleagues, created a sizeable surveybased research output in which he examined how various groups (various generations, people of various ethnic or national origin, etc.) differently remembered historical events (see, for example, Schuman and Scott 1989; Schuman and Rieger 1992; Schuman, Rieger, and Gaidys 1994; Schuman, Akiyama, and Knäuper 1998; Schuman and Corning 2000).

Therefore, both these authors examined reception of collective memories. Schwartz 
examined how individuals received and reinterpreted institutionalized memories on historical figures, and Schuman analyzed how generational experiences and socio-cultural locations affected individual remembering of historical events. My analysis of collective memories of the Yugoslav past in Chapter Four continues in this tradition: I compare institutionalized memories with their reception by young Croats, and I analyze how the young Croats' generational experiences and socio-cultural locations affected their remembering of Yugoslavia.

However, my analysis also departs from Schwartz and Schuman's analyses in two respects. First, in Chapter Five I attempt to go a step beyond analysis of collective memories' reception by examining how individuals make sense of various available presentations of the past and how they use the appropriated images. Second, both Schuman and Schwartz primarily use surveys to bring in individual beliefs, whereas I use in-depth interviews.

Surveys are powerful instruments for examining individual beliefs about the past. As Schuman and Schwartz demonstrate, by identifying distributions and frequencies of collective representations of the past across population, researchers are able to indicate how successful are institutionalized memories in influencing their audiences, they can identify what meanings are dominant in society, and also how these meanings are negotiated differently within frameworks of various social groups (e.g. generations, class...). In other words, surveys answer "what is out there" questions and provide us with generalizable patterns.

However, one weakness of surveys is that they are less able to illuminate the "how", "why" and "in which circumstances" questions. For example, in examining individual beliefs about the past surveys are weaker in examining how individuals construct their meanings (as opposed to those suggested by pre-created questionnaire categories), and how they make sense of various culturally available presentations of the past and assess them in terms of varying 
legitimacy and plausibility. In the present dissertation, I attempt to overcome this weakness by using in-depth interviews, which provide individuals with greater liberty to present meanings they attributed to stories of the past. In addition, interviews allow probing deeper into sources of these stories and into individuals' evaluations of their plausibility, and they can examine how this may affect appropriation of particular stories by individuals as their personal beliefs about the past. This is the type of analysis I do in Chapter Five.

\subsection{ISSUES IN RESEARCH OF COLLECTIVE MEMORIES}

The problem of reception is one of many possible academic explorations of collective memories. Indeed, the interdisciplinary field of collective memories encompasses various substantive and theoretical interests. For example, Olick et al. (2011) find that historiography is mainly concerned with issue of reliability in relation between memory and history, psychology examines functioning of brain in regard to remembering, and anthropology analyzes links between different types of social organization and different types of remembering. In sociology, however, many memory studies are concerned with identity, and they examine in particular collective memories' integrative and disintegrative function in constructing identities and in building social solidarity (Olick et al. 2011).

Some of substantive issues in research of collective memories and identities are intertwined with theoretical issue of reception of collective memories. As suggested earlier in this Chapter, reception is often a measure of success of the from-above memory/identity projects and can also be source of their challenges. Furthermore, the more controversial or problematic the past is, the more difficult it will be to build consensus, and therefore the past will more strongly feature in society's present. Indeed, one such difficult or traumatic past (of the Holocaust) was partly responsible for the memory boom in the 1980s (Olick and Robbins 1998; 
Misztal 2003b; Olick et al. 2011). Therefore, out of numerous substantive and theoretical issues in research of collective memories, in the rest of the section I briefly explore only three issues that are relevant for the Croatian case and that illuminate some links between identity and production and reception of collective memories. These are remembering of a traumatic or a difficult past, links between memory, nation-building and the role of the state, and challenges to “official” memories.

\section{Trauma and Difficult Past}

The two world wars and the Holocaust in particular are traumatic events that carry special significance for memory in the 20th century. The First World War marked a transition from a period of monuments, that characterized the early era of commemoration, to a period of memorials, in which the state increasingly took over duty to honor the war dead (Olick and Robbins 1998; Misztal 2003b). However, after the Second World War, the war commemorations became more difficult for many states, as they were intertwined with their "problematic behavior” in regard to the war atrocities (Olick and Robbins 1998). Therefore, the period immediately after World War Two was, for many countries, marked with significant silences. For example, the French avoided talking about persecutions of the Vichy regime (Misztal 2003b), the East Germans condemned the Nazi regime but ignored the Holocaust (Misztal 2003b; Lehmann 2011), and the Japanese were silent about their crimes against China and Korea (Kim and Schwartz 2010). Nevertheless, as the 20th century drew to its close, this changed. The memories of the Holocaust, in particular, emerged very vocally in public arena, and this reinvigoration of interest in the Holocaust was intertwined with the memory boom of the 1980s and the new focus on politics of regret (Olick and Robbins 1998; Misztal 2003b; Olick et al. 2011). 
Further, following the social and political upheavals in Central and Eastern Europe in 1989, another "problematic past" was brought to the fore: that of the communist totalitarian regimes. Arguably, the communist past is not traumatic past in the same sense as intense devastation of the wars or the atrocities of the Holocaust were. However, it certainly is a difficult past as it includes "past events that are less than glorious and whose memory induces controversy instead of consensus” (Wagner-Pacifici and Schwartz 1991:376).

There are various ways in which societies deal with a difficult past and the threat it poses to social order. One way is dealing with such a past legally. Societies can enforce remembering through, for instance, trials and public examinations of past crimes or by screening the past of candidates for public or political positions. This, for example, is what happened in Germany with opening of the Stasi files and the GDR truth commissions (Misztal 2003b; Beattie 2011), and in the Czech Republic with temporarily disqualifying former agents or informants of the secret police from serving in the high-ranking government posts (Misztal 2003b). However, societies can also enforce forgetting of some conflictual elements of the past and moving on, as, for example, happened in South Africa with the truth and reconciliation commissions (Teeger and Vinitzky-Seroussi 2007).

Another way of dealing with a difficult past can be through particular forms of commemoration. Findings from several studies suggest that how a difficult past will be commemorated depends (1) on the type of political culture, (2) on the construed continued relevance of the past for the present interests, and (3) the coalitions and resources of memory entrepreneurs or stakeholders (Vinitzky-Seroussi 2002). For example, in a society (1) with a consensual political culture, (2) in which a difficult past is no longer part of the current political agenda, and (3) in which there is a basic agreement or connection among various stakeholders, 
commemorations of a difficult past can be dissensual or multivocal, with one site providing various meanings for various audiences, as in the case of the US Vietnam Veterans Memorial (Wagner-Pacifici and Schwartz 1991; Vinitzky-Seroussi 2002). In contrast, in a society (1) with a conflictual political culture, (2) where a difficult past is still construed as politically relevant, and (3) divided stakeholders have access to diverse resources, as in Israeli commemorations of the assassinated Prime Minister and Defense Minister Yitzhak Rabin, the commemorations of a difficult past will be fragmented - Rabin was commemorated in different places at different times, and each of these separate commemorations targeted specific and disparate audiences (Vinitzky-Seroussi 2002). Finally, commemorations of a difficult past can also be enforced from-above, as it happened with the commemorations of the apartheid in South Africa, where the content and form of apartheid presentations in the first South African apartheid museum were strictly controlled (Teeger and Vinitzky-Seroussi 2007).

Testing these propositions about diverse commemorations of a difficult past across various post-communist countries - which share a similar problematic past but vary in their political cultures, their discourses on communism and their networks of communist and anti-communist stakeholders - would thus provide an invaluable insight into how different types of the postcommunist societies integrated their troublesome communist past into their collective identities. Unfortunately, to my knowledge, such a study still does not exist, and the present dissertation will not amend this situation. Examining how the post-communist Croatia commemorated its difficult communist past is beyond the scope of this study. Nevertheless, difficult communist past is implicit context of both the presentations of Yugoslavia institutionalized in history textbooks and journalistic discourse and of beliefs on Yugoslavia formed among young Croats. Therefore, I will revisit the issue of the difficult Croatian communist past in the concluding 
chapter of the present dissertation.

However, for some post-communist societies, the communist past meant more than just dealing with the past of totalitarian regimes. For successors of multiethnic communist societies, such as the USSR and Yugoslavia, it also meant dealing with their national pasts in regimes which officially attempted to create the socialist post-national identities of, for example, the Soviets and the Yugoslavians, rather than the Russians, the Ukrainians, the Serbs or the Croats. In fact, in the post-Yugoslav Croatia the issue of national identity seems to have overshadowed the issue of the post-communist justice or commemorations of the communist victims. For instance, unlike many other post-communist countries, Croatia's formal de-communization was very limited (Milardović 2007). The issue of national identity, on the other hand, was never far from political agenda of the 1990s elites, especially in context of the Croatian Homeland War.

\section{Identity and Nation-Building}

Rise of the nation-state in the 18th and 19th century is irrevocably linked with construction and increasing importance of national memory celebrated in monuments, calendars and other commemorative sites and rituals (Nora 1992; Gillis 1994; Misztal 2003b; Olick 2003a). However, the second great rise of memory in the late 20th century is linked with crisis of the nation-state and modern grand national narratives (Olick 2003a; Olick et al. 2011). The unified national identity was endangered by increasing relevance of plural particular identities (Misztal 2003b). However, these particular identities also needed memory: "When groups based on the previously private identities of citizens (race, ethnicity, sexual preferences) compete for public recognition and legitimization, their claims are rooted in their common memory of suffering, victimization or exclusion” (Misztal 2003b:134). The link between particular identities and memory does not stop with the identity politics. Memory is central for any type of personal or 
social identity as positioning oneself in regard to one’s personal past or to community's past is a key constituent of the identity construction (Olick and Robbins 1998).

Moreover, the relevance of national identities should not be easily dismissed even in these so-called post-modern or post-national times. Olick et al. (2011), for example, claim that crisis of modern narratives has further pushed nation-states towards national pasts in attempt to preserve their legitimacy. And, of course, in the new post-communist nation-states such as Croatia, the issue of national identity and commemorations of shared national past were the key elements of their nation-building. However, the 20th/21st century nation-building occurs in the circumstances different from those of the 18th/19st century nation-building. Most notably, in contemporary democratic societies, the state no longer holds monopoly over commemorative sites and rituals (Misztal 2003b).

Role of the state in constructing national identities and in shaping national memories was most famously examined by the historians Eric Hobsbawm and Terence Ranger who in 1983 published their influential book Invention of Tradition, which soon established its own tradition in the study of national memories. Studies by various authors presented in this book portray how histories were revised, commemorations constructed and national traditions invented in order to bolster interests of the nation-building elites (Hobsbawm and Ranger 1992). This approach spawned numerous studies attempting to use the same framework in analyzing contemporary national traditions and memories. However, many of these studies overlooked that Hobwbawm and Ranger's book focused on the period of the rising nation-state (Misztal 2003b). Therefore, the studies using the "invention of tradition" framework on contemporary pluralistic societies raised many criticisms, many of which identified over-emphasis on the state and neglect of challenges to "official” memories as the main problems of this approach. 


\section{Challenging the “Official” Memories}

First, by putting too much emphasis on the state mechanisms in production of collective memories, the "invention of tradition” framework neglected other actors at different societal levels that also shaped collective memories. In fact, Misztal (2003b) claims that collective memories today are no longer chiefly produced by the state, but by the (mass and electronic) media which became main sources of presentations of the past. That the media indeed affects how individuals remember historical events is evident, for example, from a study which examined how three different media generations (the print/radio generation, the black-andwhite-TV generation and the today's Internet generation) in nine different countries remembered the media-transmitted political events (Volkmer 2006). This research has found that different generations differently recalled national and international events and that these generations differently perceived credibility of their main media sources.

Further, the mass and electronic media not only mediate how different generations experience international or national historical events, but they also shape how individuals remember the past they did not experience. Primarily, individuals' images of the past come from various types of media, from Internet and cinema to documentaries and the news (Neiger, Meyers, and Zandberg 2011). TV, cinema and the new media are usually more obviously present in the everyday lives of individuals. In their shadow, the role of print journalists in shaping presentations of the past is usually neglected (Zelizer 2008; Neiger et al. 2011). However, print journalists are also important memory entrepreneurs, even though their memorywork through the news-making is not usually recognized as such (Lang and Lang 1989; Zelizer 2008; Edy 2006; Kitch 2008). Therefore, in Chapter Three I examine how journalists negotiate conventions of their profession and their relationships with state officials in different types of 
societies (authoritarian vs. democratic) and how these factors affect how journalists produce collective memories.

Further, the over-emphasis on the state-mechanisms in production of collective memories also raised criticisms for an overly instrumentalist approach of the "invention of tradition” framework. Thus, many studies in this framework identified only strategic constructions of the past by the state and political elites (Confino 1997; Misztal 2003b) and neglected both the continuity of the past and the from-below resistance and rejections of instrumentally constructed past (Schwartz 1982; Coser 1992; Olick and Robbins 1998; Misztal 2003b). Therefore, rather than adopting the instrumentalist or radically presentist approach, many authors today consider its insights, but also examine how the past is non-strategically interpreted from the present perspective and what are factors that constrain or limit malleability of the past (Olick and Robbins 1998; Olick 2003a). In this, they examine the role of the state and non-state memory entrepreneurs (Fine 1996; Armstrong and Crage 2006).

In addition, such studies also examine how the state and non-state memory entrepreneurs are both enabled and constrained by their social context (Olick and Levy 1997; Olick 2003a; Schwartz 1991), and how their memory-work is influenced by characteristics of cultural objects (Spillman 2003). Admittedly, characteristics of cultural objects have been examined less than memory entrepreneurs or social context, but a concept that can be usefully applied to this area is Griswold’s (1987b) cultural power. Specifically, cultural power can be used to explain the higher commemorability of some presentations of the past. The objects that are more commemorable are also the objects with more cultural power, which means they are multivalent enough to be adapted by various audiences, while retaining a certain degree of internal consistency or some basic consensus across these various audiences (Griswold 1987b). I present 
a more in-depth analysis of the role of memory entrepreneurs, the features of social contexts and the commemorability of cultural objects in Chapter Three.

Finally, the "invention of tradition” framework also often dismissed recipients of the fromabove or "official” presentations of the past, who were often implicitly assumed to be "dopes” of strategic revisions of the past. The so-called “Popular Memory Group” in the cultural studies provides the strongest counter-position to this view. Rather than privileging the top-down processes, the popular memory authors emphasize how groups from-below contest the "official” narratives or appropriate them for their purposes (Misztal 2003b).

Further, the popular memory approach sees memory as a result of mnemonic struggles between "official” and private memories in which the "official” (or the dominant) top-down memories are neither fully hegemonic nor are the popular (or the "vernacular”) from-below memories fully oppositional (Olick and Robbins 1998). In their view, the past is produced both “through public representations and through private memory (which, however, may also be collective and shared)” (Popular Memory Group 2011 [1982]:255). Public representations are linked to the “official” memories (the historians' work, education, museums, archives, publishing, media...), and private memories refer to the usual provenance of the oral history, such as the everyday talk, personal narratives, anecdotes and letters, journals and other "private" cultural objects.

The popular memory approach, therefore, finds its object of study in relations between these two as the study of popular memory "has to take in the dominant historical representations in the public field as well as attempts to amplify or generalize subordinated or private experiences” (Popular Memory Group 2011 [1982]:257). Nevertheless, many researchers in this approach focus on mnemonic struggles in public arena. In other words, they mainly examine the 
acceptance, the appropriations or the challenges posed to the public representations from below which then result in changes (or not) of the "official” memories.

For example, Bodnar’s (1992) famous study of “vernacular” communities of memory suggested that various US local communities put the official commemorations to unintended uses or that they reimagined their locally-organized commemorations with different focuses than those promoted by cultural authorities (Bodnar 1992). However, Bodnar also concluded that the vernacular cultures he examined in the end accepted the from-above messages of the cultural authorities and moved away from their earlier local or specific commemorative concerns.

Therefore, in this study, as in many others presenting the less-or-more successful challenges from-below (for more examples, see Olick and Robbins 1998), the challenging of the “official” memories mostly occurs at level of public mnemonic struggles. However, not all challenges and reinterpretations of institutionalized memories enter public arena. Instead, some remain at level of the individual (non-institutionalized) remembering. While some such noninstitutionalized memories have an expiration date - Assmann (1995), for example, estimates that non-institutionalized or communicative memories last for about three or four generations others may persists and at some later point affect wider culture of remembering. This, for instance, characterizes many post-totalitarian or post-authoritarian societies in which stories that were beforehand expressed only in private sphere find their way into public discourse after the regime change (Wertsch 2002). Therefore, another way in which the from-below contestations of the "official” or institutionalized memories can be examined is through reception of collective memories, which is the approach I follow in the present dissertation.

Nevertheless, the analysis of reception and the examination of intersections between institutionalized and individual memories remain the less-travelled roads in the collective 
memories research. This, however, is the main road of the present dissertation, which ultimately aims to sketch out a model of formation of collective memories that takes into account how individuals negotiate their and their family experiences in relation to perspectives on the past they acquired within their social networks and wider cultural and ideological context.

\section{OUTLINE OF THE DISSERTATION}

Chapter Two presents the emergent memory on Yugoslavia institutionalized in Croatian history textbooks and journalistic discourse in the 1990s and the 2000s and identifies the dominant presentations of the Yugoslav past. The analysis of Chapter Two sets ground for both the analyses of Chapter Three and Chapter Four.

In Chapter Three I explain developments that led to the institutionalized memories by providing a historical-institutional analysis which identifies the main memory entrepreneurs and the context in which they worked to institutionalize their perspectives on Yugoslavia in educational system and in newspapers. Chapter Three also pays particular attention to usually neglected journalistic uses of the past, and I also examine conditions for persistence and malleability of institutionalized memory.

Chapter Four compares presentations of Yugoslavia institutionalized in textbooks and newspapers with their reception among young Croats. In this chapter I also examine generational, educational, class and regional differences among the young Croats in accepting the institutionalized presentations of the Yugoslav past.

In Chapter Five, I examine how various sources of presentations of Yugoslav past, who all contributed to individuals' repertoires of collective memories, differed in their stories of Yugoslavia and how individuals evaluated their credibility and plausibility. I also examine how 
these evaluations affected appropriations or rejections of certain presentation of the past by young Croats and how these young people used the appropriated presentations to make sense of their lives.

Finally, in the concluding chapter, I re-visit the Interactional Model of Collective Memories Formation based on the present dissertations' findings. In light of these findings, I also re-visit some issues in the collective memories research sketched above. I end the dissertation with a consideration of how the findings of this dissertation on collective memories contribute to a better understanding of some issues in the sociology of culture. 


\section{Chapter 2: Institutionalized Memories of the Communist Yugoslavia in the post-Yugoslav Croatia: Framing Yugoslav Past in History Textbooks and Newspapers}

\subsection{INTRODUCTION}

Following the memory boom in the 1980s (Klein 2000; Schwartz and Schuman 2005), the dominant approaches in the field of collective memories have focused on semiotic analysis of material or embodied memory that exists independently of individuals (Assmann 1995; Nora 1996b; Klein 2000) or they have examined public discourse on the past and how it was influenced by political elites and the media (Schwartz 1996b; Confino 1997). In recent years, this structural approach to collective memories (Schwartz and Schuman 2005) has been balanced by scholars advocating an individual approach, which incorporates individual beliefs about the past and studies reception of collective memories (Confino 1997; Kansteiner 2002; Wertsch 2002; Schwartz and Schuman 2005). Rather than conflicting or competing, these two approaches are complementary - they each bring their strength to the fuller understanding of collective memories. As suggested in the previous chapter, the structural approach is strong in examining the content and characteristics of collective memories and in analyzing how and in which conditions various actors or memory entrepreneurs influence the dominant discourse on the past. The individual approach, on the other hand, is strong in recognizing and analyzing how various "audiences" negotiate and reinterpret such from-above presentations of the past.

This dissertation aims to examine collective memories from both structural and individual perspective and to bring these two dimensions together to better understand how two young Croatian post-Yugoslav generations formed collective memories of the communist Yugoslavia. For this purpose, my analysis separates the structural and the individual approach to collective memories, and then returns to the findings of each in the concluding chapter. Therefore, whereas the later chapters adopt the individual approach to collective memories, the present and the next 
chapter adopt the structural approach which examines, respectively, Griswold’s (1994) “cultural object” and the "production-cultural object-social world” nexus. The present chapter, specifically, focuses on presentations of the Yugoslav past (cultural object) institutionalized in history textbooks and newspapers of the Croatian post-Yugoslav period, whereas the next chapter delves deeper in the historical-institutional context (social world) in which these presentations of the Yugoslav past were institutionalized (produced).

Such a focus on educational and journalistic presentations of the Yugoslav past achieves a three-fold purpose. First, in the present chapter, I identify and catalogue the main presentations and evaluations of Yugoslavia institutionalized in Croatian educational system and journalistic discourse. This serves to describe "cultural object”: the emergent institutionalized memory of difficult Yugoslav past. This memory was first shaped during violent and flawed political and economic transformation of the post-Yugoslav Croatia and amidst transition from the Yugoslav totalitarian regime through the 1990s authoritarian context to the fledgling Croatian democratic society in the 2000s. I use this analysis also to examine whether the 1990s political elites dealt with recent difficult past similarly to their Yugoslav predecessors, by establishing yet another dominant uniform interpretive framework, or whether they encountered and acknowledged some public counterclaims to their preferred interpretations of the Yugoslav past. I only fleetingly touch upon this issue in the present chapter, but I pick it up again and discuss in greater detail in Chapter Three.

The present chapter also aims to establish parameters for analyses of Chapters Three and Four. First, in Chapter Three I examine the historical-institutional context and identify the main memory entrepreneurs that shaped the public interpretive framework of the Yugoslav past presented here. In other words, the analysis of Chapter Three explains development and 
establishment of publicly available memories of Yugoslavia identified in the present chapter. With this, I also examine Griswold's “production-cultural object-social world” nexus in the formation of collective memories.

Second, in Chapter Four I compare presentations of Yugoslavia institutionalized in Croatian textbooks and newspapers with interpretations of the Yugoslav past by some of their audiences. Therefore, the analysis of Chapter Four evaluates how successful were textbooks and newspapers in imposing their interpretive frameworks on a particular segment of "lay people", two young Croatian post-Yugoslav generations. With this, I also examine Griswold's "production-reception-social world" nexus in the formation of collective memories.

Therefore, with these goals in mind, I identify and compare presentations of the communist Yugoslavia across history textbooks and newspapers in the Croatian post-Yugoslav period. My analysis in the present chapter focuses on identifying the dominant textbook and newspaper presentations and on identifying oppositional and minority perspectives. In addition, with the eye to the later analysis of reception of institutionalized memories of Yugoslavia, I also examine the main textbook presentations of the Yugoslav past that were potentially available to the two examined young Croatian generations.

\subsection{STUDYING INSTITUTIONALIZED MEMORIES THROUGH EDUCATIONAL SYSTEM AND THE MEDIA}

The prominent place of institutionalized memories in the study of collective memories results partly from the very fact of their institutionalization. This gives such memories a material presence that contributes to their persistence and availability, and which is not easily matched by individual beliefs about the past (Assmann 1995; Schudson 1989a). For example, Assmann calls such publicly available presentations of the past "cultural memory" and he characterizes them as "objectivized culture - whether in texts, images, rites, building, monuments, cities, or even 
landscapes” (1995:128). Therefore, “objectivized culture” allows cultural or institutionalized memories to survive beyond three or four generations, which is, in Assmann's opinion, the life span of individual memories transmitted through social interaction. Institutionalized memories, then, provide presentations of the past with a physical form, and this form sustains and reproduces these particular memories over time (Halbwachs 1992 [1952]).

Therefore, when various groups struggle over institutionalization of a past, they struggle for their perspectives to be safeguarded for future preservation, to the detriment of alternative versions of the past. This tendency is best exemplified by the most extreme mnemonic struggles that usually occur in totalitarian societies or after the radical regime upheavals where changes in "proper" interpretation of the past are usually accompanied with a flurry of toppling of old statues and by renaming the streets and rewriting the textbooks. But, putting such extreme examples aside, the less obvious mnemonic struggles are a regular feature of pluralistic societies. Diverse groups comprising such societies negotiate their standing and their power by pushing their perspectives on the past to the forefront of public sphere. In the present study, I focus on two particular avenues through which the past can be institutionalized in the public sphere: education and the media.

The educational system, in particular, is a powerful tool for institutionalizing presentations of the past, as it provides a systematic and authoritative framework through which the widest segments of population learn about the past. In fact, many authors typically use history education as an indicator of national perspectives on past (Dierkes 2010). In authoritarian societies, in particular, groups in power usually have privileged access to shaping or even controlling history curriculum. In democratic societies, on the other hand, other factors, in addition to interests of groups in power, influence the shaping of history curriculum, as the next chapter will 
demonstrate. Nevertheless, even in democratic societies the educational system, to a certain degree, privileges the state representatives and limits access to non-elite or minority groups (e.g. stakeholders with little power or social standing). Therefore, examining presentations of the past institutionalized in history textbooks gives the clearest overview of perspectives that may be preferred by the most powerful or elite groups.

Examining the media presentations of the past brings a different strength to study of institutionalized memories. In democratic societies, the media discourse is a result of negotiations among political elites, various stakeholders and active audiences (Gamson 1992; Ferree et al. 2002). Therefore, the media discourse on the past will likely be more varied and fragmented than the textbook discourse, as various segments of the media will be sponsored by various stakeholder groups, will target various audiences and will provide various formats in which the past is presented. Examining the media discourse is, then, more likely to provide a better overview of main claims and counterclaims about the past in public discourse and to possibly identify some voices excluded from the textbook discourse. Even in authoritarian societies, where public arena for negotiation of all topics, including the past, is usually much more restricted and subject to a certain level of state control, different or alternative perspectives may still find their place in oppositional or the underground media.

In the present chapter, therefore, my first goal is to identify and catalogue presentations of Yugoslavia dominating Croatian history textbooks and newspapers. In particular, this study examines if textbooks, as the outlet most accessible to groups in power or to the state representatives, featured varied presentations and evaluations of Yugoslavia, and whether newspapers featured counterclaims or perspectives possibly excluded from textbooks. Therefore, the present chapter addresses the following questions: 
1) What were the dominant Croatian textbook and newspaper presentations of the Yugoslav past, and what evaluations of Yugoslavia did they imply?

2) What, if any, were the oppositional or the challenging presentations and evaluations of Yugoslavia featured in textbooks and newspapers?

\subsection{METHODS}

The present chapter identifies and compares the main Croatian textbook and newspaper presentations of Yugoslavia. For this purpose, I analyzed the Croatian history textbooks and the selected newspapers of the post-Yugoslav period. The analysis included all textbooks covering the 20th century history published in $1991^{6}$-2007 and used in the 8th grade of primary school, the 1st grade of vocational four-year high school, the 2nd grade of vocational four-year high school and the 4th grade of college-track high school (see Appendix A).

The examined newspapers included two mainstream (the Vjesnik and the Večernji list) and two oppositional newspapers (the Novi list and the Feral Tribune) in 1991-2007. The Vjesnik was a highbrow daily close to the Government, the Večernji list is a populist right-leaning daily, the Novi list is a regional left-leaning daily critical of the Government policies in the 1990s, and the Feral Tribune was an independent political weekly. The Feral Tribune has a special position in my sample. It started out as a satirical feuilleton in the newspaper Slobodna Dalmacija (not examined), but, due to censure in its mother-publication, its authors started their independent political biweekly (later weekly) in 1993 that soon gained reputation for outspoken and irreverent criticism of the Government. The Feral Tribune, then, differs from other newspapers in my sample in three accounts. First, it started publishing only in 1993; second, it is the only weekly; and third, much of the content preserves its original satirical tone and style. The decision

\footnotetext{
${ }^{6}$ The 1991 edition of the last Yugoslav 8th grade history textbook, which was in use for only one semester, was excluded from the analysis.
} 
to include the Feral Tribune, however, is prompted by its position as the most critical and fiercely oppositional newspaper to the 1990s authoritarian government, which continued to criticize the government after the regime change in 2000, thus being the most constant and the most outspoken voice of the independent journalism.

I sampled articles using critical discourse moments (Chilton 1987; Gamson 1992), which are periods characterized by events more likely to cause the Yugoslavia-related debate in the media. I have chosen this sampling method in lieu of examining all the issues of the newspapers (keyword search was unavailable) under presumption that it was unlikely that unprompted discussion of the Yugoslav past outside the critical discourse moments would yield enough relevant articles that would justify such a labor-intensive analysis. For each daily newspaper, I examined around a hundred days for each year (see Appendix B). For the weekly Feral Tribune, I examined all issues within relevant dates.

Further, I examined all sections of the analyzed newspapers except of the sports section, the crime section and the readers' letters section. I identified three types of relevant articles based on the title of the article, the highlighted parts (for example, a boxed text) and skimming over the content. The first type, which was of primary importance, included articles whose main topic was related to the communist Yugoslavia, to the Yugoslav leader Tito or which focused on a wider historical topic that incorporated the communist Yugoslavia (e.g. the history of the Croatian statehood). The second type included articles whose main topic was a current affair, but which included references to Yugoslavia or to Tito. Finally, the third type of articles focused on World War Two and on the war role of the communist Partisans, which is the topic related to the establishment of the communist Yugoslavia. The articles focusing on the Partisans' crimes and retributions in the aftermath of World War Two were also classified as the World-War-Two 
articles, despite chronologically belonging to the period of the communist Yugoslavia.

In examining presentations of the Yugoslav past, I use the concept of framing, which allows me to both identify the main interpretive direction of presentations of Yugoslavia and to establish their evaluative aspects. Gamson and Modligiani (1989) define frame as the central organizing idea which provides meaning for various other associated ideas. In order to successfully reach the intended audience and to provide credible interpretive pointers, the frames need to be supported by the meta-frames or the meta-narratives, which are abstract, implicitly valued and culturally-resonant interpretive packages (Gamson and Modigliani 1989). The metaframes or the meta-narratives, then, provide the frames with an overarching evaluative reference and they serve as their sources of legitimation (Steinmetz 1992; Somers 1994). As examples of meta-narratives, Steinmetz (1992) mentions Marxism, nationalism or liberalism, and in his work he uses the working class perspective as a meta-narrative.

Frames organize thinking by focusing attention on selected attributes of an issue (Gamson and Modigliani 1989; Entman 1993; McCombs and Ghanem 2001). For example, in the analysis of the abortion discourse in the USA and Germany by Ferree et al. (2002), the authors identified that, for example, the Anti-abortion-policy direction of the frame "Fetal Life" was articulated through more specific attributes such as "Life begins at birth”. Therefore, Ferree et al. organized their framing analysis hierarchically. The frames, as the central organizing ideas, were the topmost superordinate category (e.g. Fetal Life). The subordinate units were the subframes or frameletes which provided the frame with a direction or an evaluation (e.g. Anti-policy direction is a subframe of Fetal Life). Finally, the subframes/frameletes consisted of specific idea elements (e.g. Life begins at birth), which were the specific ideas articulating the frames. Gamson (1992) utilizes a similar hierarchical framing strategy in his analysis of small-group political 
discussions. For example, he identified the frame "Free Enterprise" (the highest category) which consisted of the Anti-Government Variation (the middle category) and which articulated the idea that the government aid undermined the free enterprise system (the lowest category).

My analysis follows this hierarchical framing strategy, with a slight modification. Specifically, I use meta-frames, the concept these two studies do not use, as a category superordinate to the frames. Both Ferree et al. (2002) and Gamson (1992) analyzed how one or several issues were framed (abortion, affirmative action, the nuclear power, the Arab-Israeli conflict, the troubles in the American industry). However, I examine 45 years of Yugoslavia, which can be discussed through various perspectives focusing on various issues. Therefore, I use meta-frames, or the overarching interpretive packages, to identify perspectives that present various Yugoslav issues in textbooks, newspapers, and later, in interviews.

However, within each meta-frame (e.g. “anti-capitalist system”), I use frames (e.g. “anticapitalist developments in Yugoslavia”) in the same way Ferree et al. and Gamson do: as the central organizing ideas. Each frame consists of frame attributes ${ }^{7}$, which also carry an evaluative dimension by having positive, negative or neutral implications for evaluation of Yugoslavia (e.g. "socialist economy is ruled by the party politics" is an attribute of the frame "anti-capitalist developments in Yugoslavia”, which, within the framework of positive evaluation of capitalism, implies a negative evaluation of Yugoslavia). Finally, at the lowest level are idea elements, which are specific ideas or descriptions articulating the frames (e.g. "Managers are Chosen by Political Criteria”).

The identification of main meta-frames and frames organizing presentations of the Yugoslav past was a two-step process. In the first step, I used thematic codes, or specific

\footnotetext{
${ }^{7}$ I use the term "frame attribute" to indicate similarity of my approach to McCombs and Ghanem's second level agenda-setting (2001). In McCombs and Ghanem's interpretation, "frames" are comparable to what the agendasetting researchers call "attribute agendas".
} 
utterances about Yugoslavia as the units of analysis. Each textbook was coded line-by-line for the thematic codes. Then, based on this, I identified the main meta-frames and the frames organizing the perspectives on the Yugoslav past. I repeated the process with newspapers and interviews, and then I accordingly modified the scheme of meta-frames and frames. In the second step of the analysis, I went back to the thematic codes and I grouped them into more abstract, though still quite specific, idea elements. Each idea element was assigned to a more abstract frame attribute that belonged to a particular frame of a certain meta-frame (see Appendix C for the final hierarchical coding scheme).

Some researchers, like Gamson (1992), have gone outside their data to identify all culturally available frames. This strategy allows researchers to better identify absences and transformations of frames in their data (McCombs and Ghanem 2001). However, as the present study was focused on comparisons of frames on the Yugoslav past available from different sources (textbooks vs. newspapers vs. respondents' accounts), I used only those frames that were identifiable from the examined textbooks, newspapers and interviews.

I analyzed the frames mainly in terms of presence or absence. I did not examine how particular frames were differently treated (for example, if a certain information was part of the regular text or if it was intended "for those who want to know more”). Since this study primarily examined availability of frames across different sources, the in-depth analysis of how particular frames were presented was of lesser importance. For this reason, I focus solely on the absence, presence and particular prevalence of frames, which is a strategy usually employed in the agenda setting research (McCombs and Ghanem 2001). After examining the typical appearances of idea elements in textbooks and newspapers, I decided to consider the frame prevalent if at least one of its idea elements appeared in more than 15 textbooks or more than 15 newspaper articles. 
Likewise, I considered the frame rare if none of its idea elements appeared in at least five textbooks or at least 3-4 newspaper articles. All frames in between were considered available.

\subsection{INSTITUTIONALIZED FRAMES OF THE COMMUNIST YUGOSLAVIA}

\subsubsection{Main Textbook and Newspaper Frames of Yugoslavia}

The dominant presentations of Yugoslavia in Croatian history textbooks and newspapers in 1991-2007 focused mostly on political and economic aspects of Yugoslav society, particularly detailing repressiveness of the regime and its unfair ethnic relations and ethnic tensions. Therefore, the emergent institutionalized memory of difficult Yugoslav past predominantly established a negative re-evaluation of Yugoslavia. Further, in most textbooks and newspapers, particularly in the 1990s, the presentations of ethnic problems focused especially on Croatian victimization, which was often linked both to repression of the Croats and to Serbian dominance in Yugoslavia.

The mainstream newspapers, particularly in the 1990s, contained many of the harshest or the most extreme negative portrayals of Yugoslavia. The textbooks were less likely to feature the most extreme negative presentations, but they were also characterized by a strong negative focus. All textbooks published in the 1990s and many of those published in the 2000s were univocal in portraying Yugoslavia as a non-democratic, anti-capitalist and a repressive regime, in which particular nations, the Croats foremost among them, were treated unjustly.

The dominant portrayals of the late Yugoslav President Tito were less univocal. The very first Croatian textbooks provided an unambiguously negative re-evaluation of the Yugoslav creator and ruler. After that, however, most other textbooks were silent on Tito, and this silence characterized most of the 1990s newspapers as well. Yet, in the late 1990s, Tito returns into Croatian public discourse and continues to be fairly present throughout the 2000s. His presence, 
however, is mostly limited to newspapers whose reports from various commemorations (of both Tito and World War Two) reflect the bickering among various stakeholders about a proper way to evaluate Tito. I will return to this in Chapter Three, but, at this moment, suffice to say that these debates indicate Tito's controversial evaluations in the post-communist Croatia. The statements in the newspaper reports, thus, ranged from completely condemning Tito's life and role in Yugoslavia to celebrating or even extolling him uncritically. Most of the 2000s textbooks, however, avoided this controversy by talking about Tito as little as possible.

In addition to the dominant portrayals of Yugoslavia as a non-democratic, anti-capitalist, repressive and a nationally unequal regime, which victimized the Croats, some textbooks and newspapers also featured some other minor negative re-evaluations of Yugoslavia. Since these presentations were rare in both the textbooks and the newspapers, and they were mostly absent from the interview accounts of the Yugoslav past, I will only briefly mention them. The minor negative re-evaluations described ANTI-COMMUNIST RESISTANCE in Yugoslavia. They emphasized CROATIAN CATHOLICISM, which linked the Catholic Church with the Croatian people and the Croatian identity. As one of negative CULTURAL DEVELOMENTS in Yugoslavia, they described the establishment of Yugoslav communism as a Civilizational Lapse Away from Europe. Further, they denied the Yugoslav INTERNATIONAL POLITICAL INDEPENDENCE by identifying Anti-Independent Developments of Yugoslavia's international relations, or they framed this independence negatively by portraying the strong Yugoslav international position as a Negative International Presence demonstrated in its expansionist and interventionist tendencies after World War Two. Finally, the minor negative re-evaluations also implied existence of SOCIAL INJUSTICE, which was mainly related to the post-war land redistribution and to unfair relations among various groups in the Yugoslav society. 
In the rest of this section, I present a more detailed analysis of dominant negative textbook and newspaper frames of the Yugoslav past, and then I turn to the examination of oppositional or challenging presentations of Yugoslavia.

\subsubsection{Negative Re-Evaluations of Yugoslavia in Croatian Textbooks and Newspapers NON-DEMOCRATIC AND ANTI-CAPITALIST SYSTEM}

Two most constant meta-frames in the textbook presentations of Yugoslavia suggested a political and economic re-evaluation of Yugoslavia by portraying it as a NON-DEMOCRATIC and ANTI-CAPITALIST SYSTEM (see Table 2.1). In its dominant form, the meta-frame NONDEMOCRATIC SYSTEM was primarily framed by Non-Democratic System Proper. The descriptions of Yugoslav system as non-democratic most often included explicit non-democratic definitions or descriptions of its non-democratic characteristics. Most often, the textbooks defined Yugoslavia as a one-party system, in which the Communist Party controlled all spheres of life, or as a totalitarian system or a dictatorship, they described limitations of rights and freedoms suffered by the Yugoslav citizens, or they defined the 1960s/1970s movements as movements for democratizing changes (and not, as was more frequently the case, as national movements or as movements for federal reform).

The meta-frame ANTI-CAPITALIST SYSTEM was dominantly framed by Anti-Capitalist System Proper (see Table 2.1). In the textbooks, this frame most often explicitly referred to Yugoslav non-capitalist characteristics or to inefficiency of socialist economy. Yugoslavia was thus defined as a socialist system with no free market and no private property, causing dissatisfaction among people. Some of the 2000s textbooks also sometimes presented the 1960s/1970s movements as movements for the market changes. The Yugoslav socialism was defined as inefficient because of its bureaucratic management, and this inefficiency was blamed 
for the 1980s crisis, for several waves of economic emigration, for thwarted Yugoslav

development and for harmful consequences felt in the Yugoslav society.

Table 2.1: Dominant Negative Political and Economic Re-Evaluations of Yugoslavia

\begin{tabular}{|c|c|c|c|c|}
\hline \multirow{2}{*}{ Meta-frame } & \multirow{2}{*}{$\begin{array}{l}\text { Central } \\
\text { Frame }\end{array}$} & \multirow{2}{*}{ Frame Attributes* } & \multicolumn{2}{|c|}{ Availability } \\
\hline & & & Textbooks & Newspapers \\
\hline \multirow{5}{*}{$\begin{array}{l}\text { NON- } \\
\text { DEMOCRATI } \\
\text { C SYSTEM }\end{array}$} & \multirow{5}{*}{$\begin{array}{l}\text { Non- } \\
\text { Democratic } \\
\text { System } \\
\text { Proper }\end{array}$} & $\begin{array}{l}\text { Explicit Non-Democratic Definitions (One-party } \\
\text { system, dictatorship...) }\end{array}$ & Prevalent & Prevalent \\
\hline & & $\begin{array}{l}\text { Non-Democratic Characteristics (Limitations of } \\
\text { civil rights and freedoms...) }\end{array}$ & Prevalent & Available \\
\hline & & Non-Democratic 1945 Elections & Available & Rare \\
\hline & & Democratic Evaluations of People & Rare & Available \\
\hline & & Stopping Democratizing Changes & Rare & Rare \\
\hline \multirow{4}{*}{$\begin{array}{l}\text { ANTI- } \\
\text { CAPITALIST } \\
\text { SYSTEM }\end{array}$} & \multirow{4}{*}{$\begin{array}{l}\text { Anti- } \\
\text { Capitalist } \\
\text { System } \\
\text { Proper }\end{array}$} & $\begin{array}{l}\text { Non-Capitalistic Characteristics } \\
\text { (Socialist/communist order...) }\end{array}$ & Prevalent & Available \\
\hline & & $\begin{array}{l}\text { Socialist Economy is Inefficient (Economic } \\
\text { failures linked to the } 1980 \text { s crisis and emigration, } \\
\text { harmful consequences of the socialist economy...) }\end{array}$ & Prevalent & Available \\
\hline & & $\begin{array}{l}\text { Socialist Economy is not Sustainable (Economic } \\
\text { development linked to the loans from the West) }\end{array}$ & Available & Rare \\
\hline & & Socialist Economy is Ruled by the Party Politics & Available & Rare \\
\hline
\end{tabular}

*Full list of the frame attributes and the idea elements is available from Appendix C.

Describing Yugoslavia as a non-democratic and an anti-capitalist system was a standard feature of Croatian textbooks in the whole examined period. Such descriptions also made a fairly regular appearance in newspapers (particularly references to one-party rule or to dictatorship, which were prevalent in newspapers, especially in the 1990s), although not as often as, for example, descriptions of Yugoslavia as a repressive system in which the Croats were victimized. Further, the textbooks usually presented these frames in greater detail, and they more frequently employed some "common-knowledge" descriptions, such as defining the Yugoslav order as socialist or claiming it was inefficient or non-sustainable.

Some descriptions were not evenly available from newspapers and textbooks. For example, questioning the legitimacy of the 1945 elections occurred almost exclusively in the textbooks ${ }^{8}$, and descriptions of Yugoslavia as a military system were available only from the early 1990s

\footnotetext{
${ }^{8}$ Only two textbook authors - and none before 2007 -introduced an alternative perspective to such completely delegitimizing presentations of the 1945 elections.
} 
newspapers, which coincided with armed conflict of the new Croatian state with the Yugoslav National Army (JNA). Finally, some harsher condemnations of the system, such as accusations that the Yugoslav government destroyed capitalist relations after World War Two were generally rare, but, when they appeared, they were mostly limited to a few more obviously ideological textbooks or to the 1990s mainstream newspapers.

Nevertheless, Non-Democratic and Anti-Capitalist System Proper were the dominant textbook presentations and fairly available newspaper presentations of Yugoslavia. In the context of Croatian society striving towards a democratic and a capitalistic transformation, these frames unambiguously suggested that every aspect of Yugoslavia labeled as non-democratic or anticapitalistic was to be re-evaluated negatively. Such re-evaluations permeated history textbooks. Their less frequent presence in newspapers, however, does not necessarily mean they were less relevant. On the contrary, their prevalence in textbooks and a somewhat rarer presence in newspapers likely resulted from these two meta-frames being the most unquestionable of all interpretations of the Yugoslav past. Textbooks aimed to educate new generations and, therefore, they manifested unquestioned acceptance of these frames by their prominence. Newspapers, on the other hand, were more likely to use such unquestioned interpretive frameworks as implied background knowledge that needed no further elaboration (cf. Edy 2006).

\section{REPRESSIVNESS AND ETHNIC PERSPECTIVE ON YUGOSLAVIA}

The meta-frames with a prominent role in both the textbooks and the newspapers described Yugoslavia as a REPRESSIVE SYSTEM and provided ethnic perspective on Yugoslavia. The ethnic meta-frames featured several similar and intertwined meta-frames, which differed in degree and nature of ethnic problems they implied. Therefore, different textbooks and newspapers used them differently. These ethnic meta-frames ranged from those suggesting 
Yugoslavia was a FLAWED FEDERAL STATE, which VIOLATED NATIONAL RIGHTS, to those claiming Yugoslavia was a state of NATIONAL INEQUALITIES, in which the CROATS were particularly VICTIMIZED. All these meta-frames implied a negative re-evaluation.

The meta-frame REPRESSIVE SYSTEM detailed repressive or totalitarian features of Yugoslavia (see Table 2.2). It was primarily framed by Repressive System Proper, which was strong in textbooks, and which was one of the dominant newspaper frames, particularly in the 1990s. Repressive System Proper most often described how opposition was not allowed and how it was variously persecuted and silenced through jailing, forced emigration or discrediting labels. Specific persecutions and retributions were also frequently mentioned, most notably those targeted against the actors of the 1960s/1970s movements, the remnants of defeated armies after World War Two and political emigrants. Such descriptions provided perhaps the strongest and the most pervasive condemnation of the Yugoslav repressive system, and they particularly dominated the mainstream newspapers.

Table 2.2: Repressiveness of the Yugoslav System

\begin{tabular}{|c|c|c|c|c|}
\hline \multirow{2}{*}{ Meta-frame } & \multirow{2}{*}{$\begin{array}{l}\text { Central } \\
\text { Frame }\end{array}$} & \multirow{2}{*}{ Frame Attributes* } & \multicolumn{2}{|c|}{ Availability } \\
\hline & & & Textbooks & Newspapers \\
\hline \multirow{7}{*}{$\begin{array}{l}\text { REPRESSIVE } \\
\text { SYSTEM }\end{array}$} & \multirow{7}{*}{$\begin{array}{l}\text { Repressive } \\
\text { System } \\
\text { Proper }\end{array}$} & $\begin{array}{l}\text { Opposition Not Allowed (Persecuted, treated } \\
\text { cruelly...) }\end{array}$ & Prevalent & Prevalent \\
\hline & & $\begin{array}{l}\text { Persecutions and Retributions (After WW2, in the } \\
\text { 1960s/1970s, against political emigrants...) }\end{array}$ & Prevalent & Prevalent \\
\hline & & Anti-Religious Repression (Against Catholic Church) & Prevalent & Rare \\
\hline & & Repressive Characteristics (Police State...) & Rare & Prevalent \\
\hline & & Legal System is Controlled & Prevalent & Available \\
\hline & & Internal Disciplining and Purges & Prevalent & Available \\
\hline & & Censorship & Available & Prevalent \\
\hline
\end{tabular}

*Full list of the frame attributes and the idea elements is available from Appendix C.

In addition, the textbooks often detailed anti-religious repression, particularly of the

Catholic Church. They also presented the Yugoslav Communist Party as implementing internal purges or controlling legal system. The newspapers frequently explicitly described repressive characteristics and defined Yugoslavia as a destructive police regime, which controlled people 
through fear and informants' networks. Yugoslav censorship was also mentioned, particularly the enforced Yugoslav silence on the communist Partisans' war crimes.

Ethnic perspectives on the Yugoslav past were presented in textbooks and in newspapers in several ways (see Table 2.3). At the lowest level, the meta-frame FALSE FEDERAL ORGANIZATION portrayed Yugoslavia failing is federal promise in implementation of the federation. A related YUGOSLAV UNITY VIOLATED NATIONAL RIGHTS meta-frame negatively re-evaluated the official Yugoslav politics of national unitarism that strived to create a Yugoslav identity and discouraged national expression.

The meta-frame NATIONAL INEQUALITY evaluated ethnic relations more harshly as it explicitly described ethnic tensions and national inequalities between the constituent nations/republics. Further, this frame provided specific instances of national inequalities, and they were, in the stronger form of the NATIONAL INEQUALITY meta-frame, associated with Serbian dominance. The latter was also closely related to the CROATIAN VICTIMIZATION meta-frame, which carried the strongest condemnation of Yugoslavia, expressed through portrayal of particularly poor treatment of the Croats within Yugoslavia.

Finally, portrayals of the Serbs as villains of both the NATIONAL INEQUALITY and the CROATIAN VICTIMIZATION meta-frames were closely associated with the SERBIAN NATIONALISM AS EXPANSIONISM meta-frame, which identified only Serbian nationalism as expansionism. In contrast, Croatian nationalism was interpreted as a legitimate expression of national feelings or as patriotism. 
Table 2.3: The Ethnic Perspective on Yugoslavia

\begin{tabular}{|c|c|c|c|c|}
\hline \multirow{2}{*}{ Meta-frame } & \multirow{2}{*}{ Central Frame } & \multirow{2}{*}{ Frame Attributes* } & \multicolumn{2}{|c|}{ Availability } \\
\hline & & & Textbooks / & Newspapers \\
\hline \multirow{4}{*}{$\begin{array}{l}\text { FALSE } \\
\text { FEDERAL } \\
\text { ORGANIZATIO } \\
\mathrm{N}\end{array}$} & \multirow{4}{*}{$\begin{array}{l}\text { Formal } \\
\text { Federalism and } \\
\text { Centralization }\end{array}$} & $\begin{array}{l}\text { Explicit Formal Federalism and Centralization } \\
\text { (Centralization, by the Communist Party, by } \\
\text { capital/Belgrade...) }\end{array}$ & Prevalent & Available \\
\hline & & $\begin{array}{l}\text { Formal Federalism is Unsatisfactory } \\
\text { (Movements for federal reforms...) }\end{array}$ & Prevalent & Available \\
\hline & & Tensions Caused by Formal Federalism & Available & Available \\
\hline & & Opposition to Federal Reforms & Rare & Rare \\
\hline \multirow{3}{*}{$\begin{array}{c}\text { YUGOSLAV } \\
\text { UNITY } \\
\text { VIOLATES } \\
\text { NATIONAL } \\
\text { RIGHTS }\end{array}$} & \multirow{2}{*}{$\begin{array}{l}\text { Dominant } \\
\text { Politics Violates } \\
\text { National Rights }\end{array}$} & $\begin{array}{l}\text { National Rights are Supressed (Politics of } \\
\text { unitarism, movements for national rights...) }\end{array}$ & Prevalent & Available \\
\hline & & $\begin{array}{l}\text { Dominant Ideology is Anti-National } \\
\text { (Institutional resistance to national } \\
\text { movements, unitarist labels...) }\end{array}$ & Prevalent & Available \\
\hline & $\begin{array}{l}\text { National } \\
\text { Question is } \\
\text { Unsolved }\end{array}$ & National Question is Unsolved & Available & Rare \\
\hline \multirow{5}{*}{$\begin{array}{l}\text { NATIONAL } \\
\text { INEQUALITY }\end{array}$} & \multirow{3}{*}{$\begin{array}{l}\text { National } \\
\text { Inequality } \\
\text { Proper }\end{array}$} & $\begin{array}{l}\text { 1960s/1970s Movements against National } \\
\text { Inequality }\end{array}$ & Prevalent & Available \\
\hline & & Unequal Regional Development & Prevalent & Rare \\
\hline & & Existence of National Inequality & Rare & Rare \\
\hline & \multirow{2}{*}{$\begin{array}{l}\text { National } \\
\text { Inequality as } \\
\text { Politics of } \\
\text { Serbian } \\
\text { Dominance } \\
\end{array}$} & $\begin{array}{l}\text { Unitarism is Politics of (Cultural) Serbization } \\
\text { (Movements against Serbization...) }\end{array}$ & Prevalent & Available \\
\hline & & $\begin{array}{l}\text { Serbian Political and Economic Dominance } \\
\text { (Serbs interests served by centralism, } \\
\text { Serbian hegemony...) }\end{array}$ & Prevalent & Prevalent \\
\hline \multirow{6}{*}{$\begin{array}{l}\text { CROATIAN } \\
\text { VICTIMIZATIO } \\
\mathrm{N}\end{array}$} & \multirow[t]{3}{*}{$\begin{array}{l}\text { Croatian } \\
\text { Victimization on } \\
\text { National Level }\end{array}$} & $\begin{array}{l}\text { Victimization of Croats as an Ethnic } \\
\text { Group (Denied national identity, } \\
\text { retributions, Unfair blame for WW2...) }\end{array}$ & Prevalent & Prevalent \\
\hline & & $\begin{array}{l}\text { Damaging Croatian Republic (Exploitation, } \\
\text { biological endangerment...) }\end{array}$ & Prevalent & Available \\
\hline & & Discrimination Against Croats & Available & Rare \\
\hline & \multirow{3}{*}{$\begin{array}{l}\text { Croatian } \\
\text { Victimization on } \\
\text { Individual Level }\end{array}$} & Hebrang (Croatian Communist) & Prevalent & Available \\
\hline & & Stepinac (Catholic Archbishop) & Prevalent & Available \\
\hline & & Bušić (political emigrant) & Available & Available \\
\hline $\begin{array}{l}\text { NATIONALISM } \\
\text { AS } \\
\text { EXPANSIONISM } \\
\end{array}$ & $\begin{array}{l}\text { Serbian } \\
\text { Nationalism as } \\
\text { Expansionism } \\
\end{array}$ & $\begin{array}{l}\text { Serbian Nationalism (“Great Serbian” } \\
\text { expansionism, Serbian nationalism, } \\
\text { Aggressive instances...) }\end{array}$ & Prevalent & Prevalent \\
\hline
\end{tabular}

*Full list of the frame attributes and the idea elements is available from Appendix C.

All ethnic meta-frames described above were available from textbooks and newspapers in the 1990s and in the 2000s. However, the FALSE FEDERAL ORGANIZATION and the YUGOSLAV UNITY VIOLATED NATIONAL RIGHTS meta-frames were not as prevalent as those depicting national inequality and Croatian victimization. Therefore, I will present the former only briefly. Both the FALSE FEDERAL ORGANIZATION and the YUGOSLAV 
UNITY VIOLATED NATIONAL RIGHTS meta-frames were mostly featured in textbooks, and they were less present in newspapers, where they were mainly available in the 1990s. The FALSE FEDERAL ORGANIZATION meta-frame was centrally framed by Formal Federalism and Centralization, which most often included explicit statements of the Yugoslav centralization or the dissatisfaction with such a situation. The YUGOSLAV UNITY VIOLATED NATIONAL RIGHTS was centrally framed by Dominant Politics Violated National Rights, which was typically supported by claims of forced unitarism and imposed anti-national ideology. More rarely, this meta-frame was framed by Unsolved National Question.

The ethnic meta-frames NATIONAL INEQUALITY and, in particular, CROATIAN VICTIMIZATION were stronger in their condemnation of ethnic relations in Yugoslavia. In some respects, NATIONAL INEQUELITY and CROATIAN VICTIMIZATION were very much related, but NATIONAL INEQUALITY was milder, as it did not assume a particular Croatian victimization. Rather, Croatian inequalities were part of wider Yugoslav national inequalities. NATIONAL INEQUALITY was centrally framed by National Inequality Proper, which most frequently described unequal regional development. It also mainly defined the 1960s/1970s movements as movements against national inequality at cultural, political and economic level. The cultural level is exemplified by a struggle for protection of the Croatian language and culture, the political level by a struggle for greater independence of the republics and by questioning of the Croatian position in Yugoslavia, and the economic level by a struggle for greater republic control over finances and greater economic independence. ${ }^{9}$ Finally, and less frequently, NATIONAL INEQUALITY was also framed by explicit statements to such effect.

The stronger frame of the NATIONAL INEQUALITY meta-frame portrayed National

\footnotetext{
${ }^{9}$ In textbooks, these movements were usually presented as uniting various political segments (reformist Croatian communists, actors of the Croatian cultural institution Matica hrvatska and students) in their shared struggle. In newspapers, however, the story of the internal divisions among these groups emerges.
} 
Inequality as the Politics of the Serbian Dominance. This frame, which attributed blame for national inequality in Yugoslavia to the Serbs, defined politics of unitarism as the politics of (cultural) Serbization against which the 1960s/1970s movements struggled, and it also detailed Serbian dominance/hegemony at political and economic level. Both these frames describing NATIONAL INEQUALITY in Yugoslavia were consistently available from textbooks in the whole examined period, and there were rarer in newspapers. The exceptions were idea elements detailing the stronger frame, which associated national inequality with Serbian dominance. These were prevalent in both the textbooks and the newspapers.

The stronger frame of the NATIONAL INEQUALITY was closely related to CROATIAN VICTIMIZATION, which detailed inequality of Croats within Yugoslavia. Both these metaframes were further intertwined with the (SERBIAN) NATIONALISM AS EXPANSIONISM meta-frame, which was particularly strong in the 1990s textbooks and in the mainstream newspapers. Moreover, although the meta-frame of CROATIAN VICTIMIZATION appeared in several 2000s textbooks, it was one of defining features of the 1990s textbooks. It was also, together with REPRESSIVE SYSTEM, the strongest newspaper meta-frame on Yugoslavia, particularly in the mainstream newspapers in the 1990s.

The CROATIAN VICTIMIZATION meta-frame was dominantly framed as Croatian Victimization on the National Level. Most frequently, the textbooks and newspapers identified ethnic victimization of the Croats and talked about the denied Croatian identity, oppression and retributions against the Croats and unfair diminishment of Croatian antifascism or the collective blaming of the Croats for the Ustasha crimes in World War Two. This frame also included descriptions of how Croatia was damaged, mainly through exploitation and unfavorable demographic policies. Croatian victimization was also sometimes presented through 
discrimination that was particularly targeted at the Croats.

In addition to victimization on the national level, CROATIAN VICTIMIZATION was also framed as Croatian Victimization on the Individual Level. This was a rarer frame which linked persecution and/or death of three prominent Croatian individuals (the Croatian communist Hebrang, the Catholic Archbishop Stepinac and the political emigrant Bušić) to their representation, defense or fight for the Croatian interests.

\subsubsection{The Tito Controversy}

This analysis pays particular attention to Josip Broz Tito, the Yugoslav creator and President until his death in 1980. Tito's cult of personality was one of pillars of the Yugoslav ideology and Yugoslav textbooks glorified Tito. In the post-communist Croatia, Tito is a controversial figure. On the one hand, his portrayal underwent a negative re-evaluation similar to that of Yugoslavia itself. On the other hand, Tito’s historical relevance is difficult to refute. For example, in the 2006 research on historic significance of all Croatian political leaders Tito was ranked second (Sekulić and Šporer 2007). Furthermore, he is still a very popular figure and he is even becoming a sort of a brand-name in the field of nostalgic consumerism.

The Tito controversy is to a degree reflected in Croatian textbooks and newspapers (see Table 2.4). Portrayals of Tito ranged from those extolling his political acumen and historic significance to those painting him a war criminal and a ruthless dictator. In the 1990s textbooks, for example, Tito was either presented primarily negatively or he was ignored. The textbooks reevaluating him negatively were the first Croatian textbooks written by the same author who acknowledged that Tito was a Successful Statesman, but who also particularly emphasized Tito’s Failings as a Leader, as a Man, and as a Croat. Other 1990s textbooks avoided talking about Tito at all, and rarely went beyond identifying him as the Yugoslav creator or President-for-life, 
although some also implied that his death was a turning point for Yugoslavia. All this suggested that Tito was the Key Person of Yugoslavia.

Table 2.4: Perspectives on Tito

\begin{tabular}{|l|l|l|c|}
\hline \multicolumn{1}{|c|}{ Frame Attributes* } & \multicolumn{1}{c|}{ Selected Idea Elements } & \multicolumn{2}{c|}{ Availability } \\
\cline { 2 - 4 } (-) Failings as a Leader & Dictator, criminal, weak leader... & Available & Prevalent \\
\hline (-) Failings as a Man & Hedonist, negative personality traits... & Available & Available \\
\hline (-) Failings as a Croat & $\begin{array}{l}\text { Acts against Croatian interests, crimes } \\
\text { against Croats... }\end{array}$ & Prevalent & Available \\
\hline (+) Positive as a Leader & $\begin{array}{l}\text { Historic significance, non-alignment } \\
\text { movement, antifascism, man of people... }\end{array}$ & Prevalent & Prevalent \\
\hline (+) Successful Statesman & World leader, internationally respected... & Available & Prevalent \\
\hline $\begin{array}{l}\text { (+) Positive as a Man } \\
\text { (+) Star/Celebrity }\end{array}$ & $\begin{array}{l}\text { Never taking from people, positive } \\
\text { personality... }\end{array}$ & Available & Available \\
\hline $\begin{array}{l}\text { (+/-) Key Person of } \\
\text { Yugoslavia }\end{array}$ & $\begin{array}{l}\text { Rlamorous, loved women... } \\
\text { personality... }\end{array}$ & Prevalent & Prevalent \\
\hline
\end{tabular}

*Full list of the frame attributes and the idea elements is available from Appendix C.

The textbook silence on Tito was broken only slightly in the 2000s with a couple of newer textbooks by the same author who explicitly addressed Tito’s controversial position and provided various evaluations of his rule and personality. However, most of the 2000s textbooks remained tight-lipped on Tito, stating his role as the Key Person of Yugoslavia and also sometimes mentioning his Cult of Personality. Other descriptions of Tito’s rule and role were rarer, especially compared with other figures of the same period (Hebrang or Stepinac, for example), who were often given greater prominence. A possible reason for this silence on Tito in most textbooks might be precisely his difficult and controversial evaluation in Croatian public discourse. Rather than discussing the controversy, most textbooks chose to avoid it.

In newspapers, however, the situation was different. In the early 1990s, Tito was rarely mentioned in the examined newspapers, but in the late 1990s and in the 2000s he returned with a vengeance, thus reflecting divisive public discourse on him that started to be voiced to a greater degree in this period. Some articles explicitly discussed Tito’s evaluations and they usually described how these were divided, how he was both loved and hated, how he had both positive 
and negative traits, or they discussed whether Tito's good deeds outweighed the bad or the bad deeds outweighed the good. More often, however, these divided evaluations of Tito were implied by frequently co-existing frames portraying Tito in positive and negative light.

The negative evaluations were mostly framed as portrayals of Tito's Failings as a Leader, as a Man, and as a Croat. Failings as a Leader were the most frequent - Tito was often presented as a dictator or blamed for the communist Partisans' crimes at the end of World War Two. The attribution of blame for these crimes to Tito was prevalent in both mainstream and oppositional newspapers, although the oppositional newspapers also included more numerous references to Tito's dispatch that allegedly forbade the Partisans to kill prisoners. Tito's Failings as a Man were mostly depicted by frequent references to Tito's life of luxury and his hedonism. Finally, presentations of his Failings as a Croat most frequently accused Tito of committing crimes against his own people or of acting against the Croatian interests.

In positive portrayals, Tito was praised as a Leader, Successful Statesman and a as Man, and he was also presented as a Star/Celebrity. Tito's contributions as a leader frequently included his antifascism, his position in the Non-Aligned Movement and his great political skill and historic significance. He was also presented as a man of the people and beloved by the people. On international political stage, Tito was seen as influential, respected and a great statesman who made Yugoslavia a relevant political player. The descriptions of Tito as a man were rarer and mostly limited to his positive traits or to the claims that Tito (unlike Croatian authoritarian President Tudjman) never took anything for himself. Finally, as a star/celebrity, Tito was portrayed as a glamorous showman, and as a man who liked woman. However, in this context, implications of such a portrayal were positive (unlike much rarer images of Tito as an irresponsible womanizer) as they reinforced the idea of Tito’s masculinity. 
However, more often than anything else, Tito was portrayed as the Key Person of Yugoslavia. Many descriptions within this frame were neutral or seemingly factual as they mentioned Tito’s presidency or the leading role in Yugoslavia. Others were more ambivalent, including descriptions of Tito’s death as a turning point for Yugoslavia (this can both imply Tito’s relevance and condemn him for creating the state which could not survive him) and mentions of his cult of personality. Whereas the cult of personality is in itself negative, some of its manifestations described in newspapers evoked images that became stock of popular imagery about Tito. This included the image of the whole country stopping when Tito died or various anecdotes from Tito’s childhood and life that became shared and almost cherished cultural knowledge of certain Yugoslav generations.

\subsubsection{Oppositional Textbook and Newspaper Perspectives on Yugoslavia}

Negative political, economic and ethnic re-evaluations of Yugoslavia dominated Croatian textbooks and newspapers in 1991-2007. Some moderations or relativizations of the central negative frames and some minority positive frames (see shaded areas in Table 2.5) also appeared in this period, but these were notably less frequent and less prominent than negative reevaluations of the Yugoslav past.

In addition, most of minor oppositional and positive frames remained marginalized in interviews. The only exceptions were positive social evaluations of the Yugoslav past, which emerged as extremely relevant frames among young Croats. For this reason, I will only briefly mention the minority textbook and newspaper frames, but I will not present them in detail. Solely the SOCIAL ADVANCES meta-frame will be presented in greater detail, due to its later importance in interviews.

The minor oppositional and the minor positive frames were rare in textbooks and 
newspapers (see shaded areas in Table 2.5). They were mostly located in the oppositional newspapers and in a few of the 2000s textbooks. Since these newspapers and textbooks also featured dominant negative re-evaluations, this means that the oppositional newspapers and the select 2000s textbooks were characterized by a greater diversity of perspectives on the Yugoslav past. These newspapers and textbooks, for example, were more likely to talk about capitalist developments within Yugoslav economy or about measures that improved national equality or decreased centralization. They also more frequently mentioned Yugoslav modernization or cultural developments. An occasional newspaper article even introduced some extreme oppositional views, such as claims that the socialist Self-management was better than capitalism or testimonies of freedoms in Yugoslavia.

The meta-frame SOCIAL ADVANCES was the most dominant meta-frame in young Croats' accounts of the Yugoslav past, but this meta-frame was very rarely available from textbooks and newspapers. In textbooks, it was almost completely absent, expect a few references to, for example, the right of vote given to women in 1945 or free health and education, found in the select 2000s textbooks (mostly those published as late as 2007). In newspapers, however, the SOCIAL ADVANCES meta-frame started appearing slightly more frequently in the late 1990s, when it was typically coupled with positive evaluations of Tito in reports from Tito’s commemorations. In such cases, this meta-frame usually described good or better lives and praised more rights that workers had in Yugoslavia. Yet, a few newspaper articles also mentioned that good living was illusory or true only for those who were apolitical. This, nevertheless, took a clear second place to personal testimonies of good lives that were found in the newspapers in this period. 
Table 2.5: Oppositional and Minority Positive Textbook and Newspaper Frames

\begin{tabular}{|c|c|c|c|}
\hline \multicolumn{3}{|r|}{ Meta-frames: Central Frames } & $\begin{array}{l}\text { Oppositional Frames } \\
\text { and Contradicting Idea Elements }\end{array}$ \\
\hline \multirow{13}{*}{ 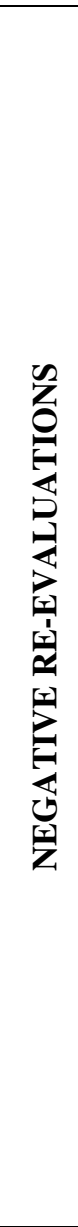 } & \multirow{8}{*}{ 䒿 } & $\begin{array}{l}\text { NON-DEMOCRATIC SYSTEM: Non- } \\
\text { Democratic System Proper }\end{array}$ & $\begin{array}{l}\text { Democratizing Changes; } \\
\text { Relativization of the } 1945 \text { Elections }\end{array}$ \\
\hline & & $\begin{array}{l}\text { ANTI-CAPITALIST SYSTEM: Anti- } \\
\text { Capitalist System Proper }\end{array}$ & $\begin{array}{l}\text { Capitalist Developments; } \\
\text { Successful Elements of Yugoslav Economy } \\
\text { (ie), Selfmanagement Better than Capitalism }\end{array}$ \\
\hline & & $\begin{array}{l}\text { REPRESSIVE SYSTEM: Repressive System } \\
\text { Proper }\end{array}$ & $\begin{array}{l}\text { Relativization of Repression; } \\
\text { Testimonies of Personal Freedoms }\end{array}$ \\
\hline & & $\begin{array}{l}\text { FALSE FEDERAL ORGANIZATION: } \\
\text { Formal Federalism and Centralization }\end{array}$ & Federal Reforms \\
\hline & & $\begin{array}{l}\text { YUGOSLAV UNITY VIOLATES } \\
\text { NATIONAL RIGHTS: Dominant Politics } \\
\text { Violates National Rights, National Question is } \\
\text { Unsolved }\end{array}$ & $\begin{array}{l}\text { Improvement of National Rights in } \\
\text { Communist Yugoslavia }\end{array}$ \\
\hline & & $\begin{array}{l}\text { NATIONAL INEQUALITY: National } \\
\text { Inequality Proper, National Inequality as } \\
\text { Politics of Serbian Dominance }\end{array}$ & National Equality Measures \\
\hline & & $\begin{array}{l}\text { CROATIAN VICTIMIZATION: Croatian } \\
\text { Victimization on National Level, Croatian } \\
\text { Victimization on Individual Level }\end{array}$ & - \\
\hline & & $\begin{array}{l}\text { NATIONALISM AS EXPANSIONISM: } \\
\text { Serbian Nationalism as Expansionism }\end{array}$ & - \\
\hline & \multirow{5}{*}{$\stackrel{\grave{g}}{\dot{E}}$} & ANTI-COMMUNIST RESISTANCE & \\
\hline & & CROATIAN CATHOLICISM & \\
\hline & & $\begin{array}{l}\text { CULTURAL DEVELOPMENTS: } \\
\text { Civilizational Divide }\end{array}$ & \\
\hline & & $\begin{array}{l}\text { INTERNATIONAL POLITICAL } \\
\text { INDEPENDENCE: Negative International } \\
\text { Presence, Anti-Independent Developments }\end{array}$ & \\
\hline & & $\begin{array}{l}\text { SOCIAL INJUSTICE: Land Re-distribution, } \\
\text { Unfair Social Relations }\end{array}$ & \\
\hline \multirow{4}{*}{\multicolumn{2}{|c|}{$\begin{array}{l}\text { Minor Positive } \\
\text { Evaluations }\end{array}$}} & \multicolumn{2}{|c|}{ SOCIAL ADVANCES: Social Advances Proper, Social Advances with Problematic Aspects } \\
\hline & & \multicolumn{2}{|c|}{$\begin{array}{l}\text { INTERNATIONAL POLITICAL INDEPENDENCE: Oppositional Position to Stalin and the } \\
\text { USSR, International Political Player }\end{array}$} \\
\hline & & \multicolumn{2}{|l|}{ MODERNIZATION } \\
\hline & & \multicolumn{2}{|c|}{ CULTURAL DEVELOPMENTS: Cultural Advances, Link with the Western Culture } \\
\hline
\end{tabular}

\subsubsection{Transitional and Post-communist Generation and History Textbooks}

In addition to identifying dominant presentations of Yugoslavia available from Croatian history textbooks and newspapers, the present chapter also sets ground for analyses of later chapters, including comparison of institutionalized presentations of the past with their reception by two young Croatian generations. For that purpose, in this section I trace educational progress of these two generations and I discuss frames of Yugoslavia available from their textbooks (see 
Appendix A for the list of textbooks used by these two generations).

Croatian pupils first encounter national history of the 20th century in the fourth grade of primary school. The transitional generation attended the fourth grade in the Yugoslav educational system and they used the one approved textbook, which exposed them to the Yugoslav take on its history in form of a narrative or a story-telling structure. This textbook primarily discussed World War Two and the Partisans' heroism (in some 20 pages), and then celebrated Tito, the Yugoslav ideological pillars and the might of the Yugoslav society. The post-communist generation attended the fourth grade in the late 1990s and they used one of two available textbooks published in 1998. Both presented the Yugoslav past in 1-2 paragraphs based on historical fact, but, at the same time, these textbooks explicitly interpreted presented facts. One of the textbooks mentioned solely the communist rule obstructing national interests, while the other provided more information about Yugoslav repressiveness and economic problems, and it blamed Serbian hegemony for the Yugoslav dissolution.

The next contact with the 20th century history occurs in the 8th grade of primary school. The transitional generation used the only available textbook published in 1992/93. This textbook presented almost exclusively negative Yugoslav political and economic re-evaluations, in particular repressiveness and Croatian victimization (see Table 2.6). Tito was also mainly negatively re-evaluated. The post-communist generations attended the 8th grade in the 2000s. In this period, their teachers could choose among several textbooks. Therefore, as seen from Table 2.6, this generation could potentially encounter both the dominant negative re-evaluations of Yugoslavia (many of which, however, were considerably toned down in language and tone), but also some positive or oppositional frames that were not available to the transitional generation in the 8th grade. However, which of these frames of the Yugoslav past the post-communist 
generation did encounter depended on their teachers' textbook choice. As I elaborate in the next chapter, some of the 2000s textbooks continued a type of discourse similar to that of the previous period, and these textbooks were also potentially available to the post-communist generation. This problem, unfortunately, is out of bounds of the present analysis which can address only what was potentially available.

Table 2.6: Meta-frames Available to Two Generations in the $8^{\text {th }}$ grade of Primary School

\begin{tabular}{|l|c|c|}
\hline \multicolumn{1}{|c|}{ Meta-frames } & Transitional Generation & Post-Communist Generation \\
\hline NON-DEMOCRATIC SYSTEM & $\begin{array}{c}\text { Yes, but not including Democratizing } \\
\text { Changes }\end{array}$ & Democratizing Changes included \\
\hline ANTI-CAPITALIST SYSTEM & $\begin{array}{c}\text { Yes, but not mentioning Capitalist } \\
\text { Developments frame nor the successful } \\
\text { periods of socialist economy }\end{array}$ & Capitalist Developments included \\
REPRESSIVE SYSTEM & $\begin{array}{c}\text { Yes, but not Relativizing the } \\
\text { Repressiveness }\end{array}$ & Relativizing the Repressiveness \\
\hline $\begin{array}{l}\text { FALSE FEDERAL } \\
\text { ORGANIZATION }\end{array}$ & $\begin{array}{c}\text { Yes, but mostly limited to explicit } \\
\text { statements of centralization and not } \\
\text { mentioning the Federal Reforms }\end{array}$ & Federal Reforms included \\
\hline $\begin{array}{l}\text { YUGOSLAV UNITY VIOLATES } \\
\text { NATIONAL RIGHTS }\end{array}$ & $\begin{array}{c}\text { Yes, but limited to the Dominant Politics } \\
\text { Violates National Rights frame }\end{array}$ & Yes \\
\hline NATIONAL INEQUALITY & $\begin{array}{c}\text { Yes, but not mentioning National } \\
\text { Equality Measures }\end{array}$ & Yes \\
\hline CROATIAN VICTIMIZATION & Strong emphasis & Yes \\
\hline $\begin{array}{l}\text { (Serbian) NATIONALISM AS } \\
\text { EXPANSIONISM }\end{array}$ & Yes & Yes \\
\hline $\begin{array}{l}\text { ANTI-COMMUNIST } \\
\text { RESISTANCE }\end{array}$ & Yes, but limited to Catholic Church as & Yes \\
\hline CROATIAN CATHOLICISM & Site Resistance & Yes \\
\hline SOCIAL ADVANCES & No & Yes \\
\hline SOCIAL INJUSTICE & No & Yes \\
\hline $\begin{array}{l}\text { INTERNATIONAL POLITICAL } \\
\text { INDEPENDENCE }\end{array}$ & Yes & No \\
\hline MODERNIZATION & No & \\
\hline CULTURAL DEVELOPMENTS & No & Yos \\
\hline
\end{tabular}

Next is high school, but here Croatian pupils diverge in their history education. The secondary education in Croatia is divided into vocational and college track. Pupils who go to vocational high schools learn about Yugoslavia in their first or second year, and those in collegetrack high schools learn about it in their fourth year. In vocational schools, the amount of the learning material is significantly reduced compared with the 8th grade material, and particularly compared with college-track high schools, where history lessons are the most comprehensive. As 
a result, vocational pupils are unlikely to encounter any new information on Yugoslavia in their secondary schooling. In contrast, their college-track counterparts should spend a significant amount of their senior year discussing Yugoslavia. As will be seen in Chapter Four, this different exposure to information about Yugoslavia has distinct consequences for these young people's knowledge of Yugoslavia.

Most vocationally educated members of the transitional generation did not use any history textbook as their schooling coincided with the vocational textbook gap during the Homeland War (discussed in the next chapter) ${ }^{10}$. The college-educated members of the transitional generation had several available textbooks in their senior year of college-track high school. All these textbooks, however, were similar to the 1992/93 8th grade textbook described above (indeed, one of the authors was the same) - they contained more details on many negative aspects of Yugoslavia, but typically they did not introduce any new oppositional or positive frames. Therefore, the transitional generation was exposed to the Yugoslav ideology early in their schooling, and to a radical negative re-evaluation of Yugoslavia later in their schooling.

The textbooks potentially available to the vocationally educated post-communist generation, as all vocational textbooks, had relatively little information dedicated to Yugoslavia. Therefore, many frames - mostly those moderating or relativizing the central negative frames that were available to them in the 8th grade were now missing. In contrast, the post-communist pupils of college-track high schools were potentially exposed to all frames available in the 2000s. Of course, what were actual frames available to them depended on textbooks they used. This, as already said, is out of bounds of the present analysis, although in Chapter Five I do attempt to address this issue indirectly, through discussion of sources of presentations on the

\footnotetext{
${ }^{10}$ Although, it is likely that their teachers, if they taught about Yugoslav history at all, did not deviate much from a shortened version of the 1995 history curriculum based on the 1992/93 8th grade textbook described above.
} 
Yugoslav past among young Croats.

\subsection{CONCLUSION}

The analysis of Croatian history textbooks and newspapers in 1991-2007 suggests that the emergent institutionalized memory of the recent and difficult Yugoslav past was dominantly framed in negative terms. Specifically, Yugoslavia underwent a political and economic negative re-evaluation, with a particular focus on repressive elements of former regime and its ethnic problems, most notably Croatian victimization. Arguably, the only elements of the Yugoslav past that escaped such a complete re-evaluation in institutionalized memories on Yugoslavia were presentations of former Yugoslav leader Josip Broz Tito. After a period of a relative silence on Tito in the early 1990s, his negative re-evaluations fought head to head with persisting positive evaluations of Tito's rule and his historic significance that re-emerged in newspapers in the late 1990s and in the 2000s.

Indeed, this was the only major aspect of presentations of the Yugoslav past in which textbooks, mainly preserving the silence on Tito and avoiding the controversy, distinctly differed from newspapers. In most other aspects, negative portrayals of Yugoslavia that dominated the textbooks were reproduced in the newspapers. However, the newspaper accounts were usually more simplified or, at least, less detailed in many of their presentations of the Yugoslav past. But, at the same time, the newspaper accounts were also usually more likely to feature the more extreme perspectives on Yugoslavia, both those on the side of its detractors (which were available from the mainstream newspapers) and those on the side of its defenders (more often located in oppositional newspapers).

In this period, oppositional or challenging presentations of Yugoslavia that would, for example, imply a positive evaluation of some aspects of the Yugoslav past, were available from 
textbooks and newspapers, but they were rare and overshadowed by major negative reevaluations. When such oppositional views appeared, they were more likely located in the oppositional newspapers and in a few select 2000s textbooks. Therefore, with negative reevaluations dominating most newspapers, and particularly the mainstream newspapers, as well as having a steady and constant presence in all the 1990s textbooks and many of the 2000 textbooks, it seems that the emergent institutionalized memory on Yugoslavia in the Croatian initial post-Yugoslav period favored a uniform, rather than pluralistic, interpretive framework. In Chapter Three I turn to examination of historical-institutional factors which shaped such a uniform interpretive framework of the Yugoslav past and which obstructed development of more diverse public interpretations of Yugoslavia. In addition, in later chapters I also examine how successful was this uniform interpretive framework of the Croatian past among young Croatian generations. 


\section{Chapter 3: Producing Collective Memories "From Above”. Uses of the Yugoslav Past in Croatian Post-Yugoslav History Education and Journalistic Discourse}

\subsection{INTRODUCTION}

In the present chapter, I continue with structural approach to collective memories and its focus on institutionalized memories. In the previous chapter, I identified main Croatian textbook and newspaper frames of the Yugoslav past. They were mainly characterized by negative political and economic re-evaluations of Yugoslavia and concentrated in particular on Yugoslav repressiveness and ethnic problems, especially Croatian victimization. In fact, the examined institutionalized memories of Yugoslavia presented little diversity in discourse on Yugoslavia. Many textbooks and newspapers used only this uniform interpretive framework and there was little space for alternative evaluations or for different perspectives, such as social perspectives. Although some of the 2000s textbooks and some articles, particularly in oppositional newspapers, occasionally discussed Yugoslavia in a more varied manner, they also generally offered mostly negative re-evaluations. The only frames departing from this were positive evaluations of Yugoslav president Tito and rare descriptions of better lives or more rights workers had in Yugoslavia, which were offered mostly in reports from commemorations of Tito in the late 1990s and in the 2000s.

In the present chapter I expand this analysis by examining how and in which circumstances the above frames of the communist Yugoslavia were produced. In particular, I focus on identifying how main actors or memory entrepreneurs used the Yugoslav past and on historicalinstitutional context within which they acted. I use this analysis to explain how textbook and newspaper frames of Yugoslavia presented in the previous chapter were shaped and how they came to dominate public discourse on Yugoslavia. In addition, with this analysis I also examine malleability and persistence of institutionalized presentations of the Yugoslav past in the post- 
Yugoslav Croatia.

As suggested in Chapter Two, I focus on education and the media as two important instruments producing collective memories. Power of education stems most prominently from state regulation. Governments organize formal schooling and, to some extent, shape history curricula and guide the textbook adoption system (Apple 2000, 2003). Nevertheless, various societies differ in organization of educational system and in the degree of state control in hands of groups such as ruling party cadres, civil servants or academics (Dierkes 2010). Different “educational policy-making regimes” (Dierkes 2010), then, result in different types of presentations of the past available to students in schools. Further, various societies also differ in degree or influence of public challenges made by stakeholders excluded from the policy-making process. Examining educational memory entrepreneurs and their historical-institutional contexts, therefore, may explain why some presentations of the past become institutionalized in textbooks and others do not.

Whereas influence of history education on collective memories may seem an obvious point, journalists' role in influencing perspectives on the past is less apparent. Indeed, some authors (Zelizer 2008; Kitch 2008) have suggested that both scholars and journalists often erroneously assume that journalists have little to do with presentations of past as they typically focus on news-making and here-and-now. However, journalists use the past in many ways. The most obvious is commemorative journalism. Even more importantly, journalists regularly use the past to frame their “current” stories, which is often not recognized as a memory-work (Lang and Lang 1989; Zelizer 2008; Edy 2006; Kitch 2008). Further, despite suspicion of the media bias by specific audiences (see, for example, Cramer Walsh 2004), journalists are often seen as credible commentators, since democratic journalistic conventions require neutrality and objectivity 
(Zelizer 1992; Edy 1999). However, many news scholars note that journalists often adopt official versions (Gamson and Modigliani 1989; Beamish, Molotch, and Flacks 1995; Schudson 1989b; Edy 2006), or that they prefer official sources to other stakeholders (Gamson and Stuart 1992). Therefore, in gauging journalistic role in producing collective memories, it is important to identify how journalists present the past explicitly and implicitly, and whose perspectives they privilege in different institutional contexts.

In the present chapter I examine how the past of the communist Yugoslavia was used in the Croatian post-Yugoslav period in the educational system and in the media. I examine the historical-institutional context of the 1990s and the 2000s, and I analyze how main memory entrepreneurs used the Yugoslav past and, as a result, whose perspectives on Yugoslavia gained access to the Croatian schools and newspapers. By focusing on these two aspects, the goal of the present chapter is to specify Griswold’s (1994) “production-cultural object-social world” nexus in the formation of collective memories on Yugoslavia. At the same time, I also examine how malleable was the Yugoslav past in textbooks and newspapers, and under which conditions the Yugoslav past has shown resistance to post-Yugoslav reinterpretations.

\subsection{PRODUCTION OF COLLECTIVE MEMORIES: ROLE OF HISTORY TEXTBOOKS AND JOURNALISTIC PRESENTATIONS OF THE PAST}

\subsubsection{Uses and Malleability of the Past in Production of Collective Memories}

The link between collective memories and nation-building is widely recognized today. Indeed, introduction of commemorative practices coincided with the 18th and 19th century rise of the nation-states in which new political elites of the urban middle and working classes took over the institutionalization of memories from the monarchy, Church and the aristocracy and started celebrating national memory through monument-building and public rituals (Nora 1992; Gillis 1994). By providing a perspective on shared history, political elites offer both a positive 
and a negative identification for a collective entity and thus they can more easily gain support for their policies and for legitimization of their power (Gillis 1994; Kansteiner 2002). Therefore, political elites have a vested interest in institutionalizing perspectives on the past which anchor and sustain their underlying collective identity (Halbwachs 1992 [1952]).

In addition, political elites might be in privileged positions to institutionalize their perspectives on the past, since those in power have state resources at their disposal and thus they can make decisions about commemoration. Indeed, in interpretations of some radically or instrumentally presentist authors, political elites strategically manipulate and revise history so it fits with their interests (see in Olick and Robbins 1998). However, most authors prefer a more moderate version of the presentist argument, which removes the aspect of strategic manipulation. Rather, narratives of the past serve present needs and concerns by reflecting actors' experiences and current cultural understandings (Coser 1992; Olick and Robbins 1998). In addition, there are limits to reinterpretations of the past (Schwartz 1982; Coser 1992; Schudson 1992; Olick 2003a). Therefore, both strategic and non-strategic memory-work of political elites and other memory entrepreneurs may be influenced by factors which limit malleability of the past. These conditions can roughly be separated into factors of Griswold’s (1994) "social world/context” ,“cultural object” (presentations of the past) and “creators/producers” (memory entrepreneurs or stakeholders).

First, networks, alliances and resources of memory entrepreneurs affect whether some interpretation of the past persists or whether it shifts. In addition to political elites, other groups may also have a stake in sponsoring some presentations of the past. For example, in the Watergate case certain politicians and journalists made careers out of their interpretations of these events (Schudson 1992), and criticisms of the President Harding after his death were used 
by the Democrats and the Progressive Republicans to criticize the US they thought his administration represented (Fine 1996). Conversely, if a presentation of the past has no sponsors, it will likely disappear from public memory, as it happened with positive images of Harding, who was very popular during most of his term, but who found himself without defenders (“reputational entrepreneurs") after his death, in the wake of scandals associated with him and most of his associates (Fine 1996).

Further, memory entrepreneurs or stakeholders who are better institutionally placed and who have better resources at hand to disseminate their claims will likely be more successful in preserving their interpretations or in changing established interpretations of historical events and reputations (Fine 1996). For example, the dominant version of the Watergate scandal was the one sanctioned by the political establishment (Schudson 1992). However, elites and their perspectives may also shift, as demonstrated by fall and rise of reputation of folk singer Pete Seeger. He was initially vilified by the media and the political establishment, but new generations and changed political establishment celebrated him (Bromberg and Fine 2002). Further, elites may be fragmented or divided, as seen from racial divisions in US legislators’ presentations of Martin Luther King (Polletta 2003).

Finally, non-elite or non-state actors may successfully compete with elites if they have alternative resources. The Vietnam War veterans, for example, rejected non-traditional form of the Vietnam Memorial and successfully added an American flag and a more traditional statue to it (Wagner-Pacifici and Schwartz 1991). Similarly, Armstrong and Crage (2006) show how gay activists were able to institutionalize the Stonewall riots by engaging support of wide segments of the LGBT population at a particular historical moment and by gaining access to the mainstream media coverage. Therefore, the high "mnemonic capacity” (Armstrong and Crage 
2006) of non-elite actors (e.g. organizational skills or the media access) may compete with a favorable institutional placement of elites.

Memory entrepreneurs, however, may be both constrained and enabled by their social and institutional context. First, reinterpretations will be easier if they fit current interpretive frameworks. For example, the more egalitarian US culture after the Civil War supported rise of the more egalitarian Washington's reputation (Schwartz 1991). Conversely, tradition or previously accumulated past may obstruct reinterpretations. For instance, changes in the Capitol's iconography of the great American events are increasingly difficult as the old images are never removed and space is limited (Schwartz 1982). Likewise, the memories that are already institutionalized affect how events will be remembered long after they are gone from living memory (Assmann 1995). Nevertheless, for some time, the living memory constrains reinterpretations or malleability of the past. As Schudson notes in his examination of the Watergate memory, “(p)eople will not release important personal or group memories without a struggle” (1992:207).

Further, many presentist reinterpretations are possible because they serve an integrative function. For example, Ducharme and Fine (1995) showed that demonization of traitor Benedict Arnold, where all his former contributions were erased from memory, re-affirmed idealized values of the US society of that time. Likewise, Olick (2003b) demonstrated that the normalization of the Nazi past in German public discourse was possible only after the 1989 changes in political culture. Pre-1989 German political culture, developed by the second postwar generation, prevented all earlier attempts at the changed interpretation or normalization of the discourse on World War Two (Olick and Levy 1997; Olick 2003b).

In addition, some periods or some societies also affect how easy it is to reinterpret the past. 
For example, Swidler argues that cultural interpretations are more changeable during social upheavals (“unsettled times”), whereas people in stabile periods are more likely to keep their habitual or traditional interpretations (Swidler 2000; Schudson 1989a). Similarly, reinterpretations will be more difficult in traditional than in non-traditional societies. For instance, Zhang and Schwartz (2003) found that different aspects of Confucius were celebrated in public discourse before, during and after the Chinese Cultural Revolution, but that, still, traditional Chinese society resisted reinterpretations of Confucius comparable to reinterpretations of Washington and Lincoln in the US society. Further, the immediate institutional configurations matter as well. For example, a different organization of the 2005 truth and reconciliation commission on the Greensboro Massacre changed type of narratives and diversity of perspectives on the Massacre in 2005 compared with those voiced in the initial federallysponsored investigation in 1980 (Cunningham, Nugent, and Slodden 2010).

Finally, characteristics of cultural objects or presentations of the past also affect their persistence or malleability. For example, social psychologists Pennebaker and Banasik (1997) claim that the past events are more memorable if they are momentous or life-changing (e.g. wars or the historical turning points), which also makes them more likely featured in the media or officially commemorated. Therefore, social impact of events affects their commemorability. In addition, events that are forcefully silenced (in totalitarian societies, for example) may also gather emotional salience that makes them memorable (Pennebaker and Banasik 1997) and they are likely to be institutionalized after silence is broken (Wertsch 2002). The events that are dramatic are also more forceful rhetorically, and thus more commemorable (Schudson 1989a, 1992), as exemplified by dramatic nature of the Stonewall riots which also contributed to their institutionalization (Armstrong and Crage 2006). 
Commemorability is also affected by genre fit. If the presented past does not fit expectations of audience or if it is not appropriate in an institutional context, the commemoration may fail due its lower "rhetorical force” and lower "resonance" (Schudson 1989a) or it may not even be allowed to happen. For example, the veterans of the Vietnam War rejected the statecommissioned Vietnam War Memorial because they interpreted its non-traditional form as “nonpatriotic and nonheroic” and thus demeaning (Wagner-Pacifici and Schwartz 1991:395). Similarly, Polleta (2003) demonstrates a genre-appropriate commemoration when she argues that the African American legislators could use images of Martin Luther King Jr. on the House and the Senate floor only during "proper” commemorative occasions. Finally, Fine (1996) also emphasizes this link between appropriate use of a cultural object and its commemorability when he specifies that the successfully constructed reputations have features of a good story and demonstrate an effective use of symbols and imagery.

The commemorability of a cultural object may be affected by Griswold’s (1987a) “cultural power” - by its ability to evoke diverging interpretations while sustaining an underlying consensus about its meanings. This is, for example, demonstrated by Spillman's research (2003) in which she showed that the Australian centennial celebration of the British invasion and the convict settlement could not be sustained a century later, whereas the US founding moment, the American revolution, was multivalent enough to persist both in the centennial and in the bicentennial celebration. The minority groups gaining voice in the 20th century criticized some mainstream interpretations of the American Revolution, but they still accepted underlying consensus about its importance. In contrast, these groups in Australia did not find a way to reinterpret the founding moment as something that included them as well. Likewise, Schudson (1992) also attributes persisting relevance of Watergate in US public discourse to its 
complexities and ambiguities that allowed various appropriations of Watergate across the US political spectrum. Diverse groups find in Watergate something that fits their needs and perspectives and thus they keep these images alive.

Therefore, whether a memory will persist or whether its interpretations will shift depends on various factors. First, it depends on resources and alliances of memory entrepreneurs. Those who are better institutionally placed (Fine 1996) or have higher mnemonic capacities (Armstrong and Crage 2006) will be better able to institutionalize their perspectives on the past (be that reinterpretations or not), especially if they are not opposed or if their challengers are disadvantaged (Fine 1996; Bromberg and Fine 2002). Next, characteristics of presentation of the past will affect its malleability. The semiotically multivalent (Spillman 2003) or the high-incultural-power (Griswold 1987a) presentations will more likely be commemorated by various audiences. Likewise, memories will be more successful if presented in credible or resonant forms (Schudson 1989a; Fine 1996). Persistence of memories is also enabled by their institutional retention (Schudson 1989a; Assmann 1995), and the more momentous or dramatic events or figures will more likely be institutionalized (Pennebaker and Banasik 1997; Schudson 1989a, 1992; Armstrong and Crage 2006). However, presentations that are part of the living memory might also prove resistant to reinterpretations, at least for a while (Schudson 1992). Finally, context affects malleability of memory as well. In particular, existing political culture (Olick and Levy 1997; Olick 2003b), continued cultural salience of the past interpretations (Schwartz 1991) or the force of habit or tradition (Schwartz 1982) will all contribute to persisting images of the past.

As the previous chapter demonstrated, although most of the Yugoslav past was radically re-evaluated in textbooks and newspapers, some positive evaluations of the late Yugoslav leader 
Tito have re-emerged and persisted in the newspapers since the late 1990s. In order to explain both malleability of Yugoslavia and persistence of Tito, I look closely at factors that enabled or constrained memory work of the main memory entrepreneurs in the Croatian educational system and in the media.

\subsubsection{How History Education Produces Collective Memories}

The relevance of education for collective memories is evident from many battles fought over content of history curriculum and textbooks. Even the purpose of history education is contentious. Many groups see history education as a legitimate instrument for instilling their youth with national consciousness, whereas others argue for a critical and plural approach to history (Podeh 2000; Koren and Baranović 2009). In this arena of struggle, however, ruling elites have an advantage over other stakeholders as the government or the state regulates how history curriculum and textbooks are adopted in all types of societies. In democratic societies, however, the state decisions are open to challenges and negotiations (Apple 2000). In contrast, the governments in dictatorships and authoritarian regimes are likely to retain a much firmer control over history education (Evans 2003). For example, in the German Democratic Republic (GDR), the loyal government officials controlled educational policies (Dierkes 2010). In such regimes, then, elites' perspectives on the past are the only voice given access to classrooms, which may result in their undue influence over collective memories. As Wertsch's research (2002) on the Soviet-educated Russians shows, even when "lay individuals” distrust narratives of their totalitarian governments, they are still able to reproduce them fully.

Democratic societies, on the other hand, differ in their educational policies and may have different groups in charge of adopting history curriculum and textbooks. Different organization results in different types of presentations of the past distributed in schools. For example, in 
centralized system of post-World-War-Two Japan, the main decisions were made by the Ministry of Education bureaucrats who sustained the fact-based teaching in schools despite criticisms and challenges from other stakeholders (Dierkes 2010). In contrast, in the post-war West Germany, the central role of teachers as academic authorities resulted in thematic teaching of history and discussions of the past, including the problematic Nazi past (Dierkes 2010). Societies with developed market economies and decentralized textbook adoption system, such as the USA, however, give greater role to publishing companies and to audiences to which they cater (Apple 2000). This can result in most publishers preferring the most consensual version of the past in fear of giving offense (Schudson 1992). Therefore, different groups may have different access to classrooms, depending on institutional educational regime in which they act. In the present chapter, therefore, I seek to assess how the Croatian educational context influenced whose perspectives gained access into classrooms.

\subsubsection{How Journalists Produce Collective Memories}

The role of the journalists in shaping collective memories is curious as there is little place for the past in acknowledged journalistic focus on the current and the newsworthy. The only past-related articles journalists “legitimately” write are commemorative articles marking events or people relevant to society or to journalistic profession. These are acceptable in part because they do not deviate too much from conventions of newsworthiness and neutrality. Since commemorative articles are typically reports on institutionalized markers of the past (e.g. official commemorations), this makes them newsworthy (Edy 1999, 2006). They also align well with positioning of journalist as a neutral observer who only reports on the past as discussed in the public speeches or in perspectives of stakeholders at public events. Even when commemorative articles are not reports, but the full features, they still carry authority of a legitimate and neutral 
use of the past, primarily because they are often presented in form of seemingly factual descriptions or lists of the key past moments, or because they include testimonies of experts or witnesses or protagonists of more recent events (Edy 2006). History, however, is often full of controversies that simple descriptions or the selected voices do not capture - but, in their presentation, journalists’ interpretive role remains hidden (Edy 2006).

Nonetheless, journalists certainly act as interpreters for the past they commemorate. For example, a lot of background information is routinely left out from articles as the public is assumed to already know (or should know) about it. This allows journalists to decide what is salient when introducing their topic (Edy 2006). Similarly, journalists choose stories that are "good narratives", or they employ narrative devices to make story of the past more attractive or more accessible to their readers, which often leads to simplifications (Edy 2006). Finally, the stories of the past need sponsors to survive (Edy 2006). If the past is not considered politically relevant, incumbent officials may be less important as sponsors, but some other groups may take up that role - such as former officials or protagonists of more recent events (Edy 2006). In addition, journalists can also claim an eyewitness authenticity, which reinforces their authority (Edy 2006; Zelizer 1992). Even when the passage of time makes this impossible, journalists still possess certain cultural authority which allows them to evaluate the present events in their wider temporal context (Zelizer 1992).

In addition to commemorations, which are the main journalistic vehicle for discussing the past, journalists also use the past as implicit framework of their stories (Edy 2006; Zelizer 2008). For example, they use analogues to compare the past and the present and to draw lessons from the past for the present (Edy 2006; Zelizer 2008). Although the analogues rely on the assumed readers' knowledge (they rarely provide details on the past), which can limit their influence on 
collective memories, they still firmly push readers into the same interpretive direction journalist has assumed (Edy 2006; Zelizer 2008). Also, journalists may use historical contexts and explicitly elaborate the past in order to make sense of some current developments (Edy 1999, 2006). While the analogues may be used often, the historical contexts are typically rare since the explicitly evaluative role speaker must take does not quite fit the journalistic conventions of neutrality and fact-reporting (Edy 1999). Still, the historical contexts, when they appear, may be influential sources of presentations of the past.

Therefore, journalists do have a role in shaping collective memories. They routinely do the memory-work in their commemorations, historical contexts and historical analogues. Arguably, the journalistic memory-work may be even more influential than the more obvious memorywork done, for example, through history textbooks or museums, due exactly to its low visibility and presumed neutrality and objectivity of journalists. However, more than any other types of stories, the journalistic stories on the past depend on the presence of "sponsors"/stakeholders or memory entrepreneurs, who make certain interpretations of the past of interest to journalists by keeping them commemorated or alive in public discourse. Therefore, in the present chapter I seek to assess what was the role of Croatian journalists in production of collective memories on Yugoslavia, and how their institutional contexts may have shaped the manner in which they presented the Yugoslav past.

In the present chapter, therefore, my first goal is to identify the main Croatian memory entrepreneurs and to sketch out the main factors enabling or constraining their memory work in the history education and journalistic discourse on Yugoslavia. In addition, I also examine how malleable or persistent were presentations of the Yugoslav past in history textbooks and newspapers. Hence, the present chapter addresses the following questions: 
1) Who were the main actors shaping Croatian history curriculum and history textbooks, and what was institutional context in which they acted? How did these actors use the Yugoslav past, and whose perspectives on the past were available from the Croatian history textbooks in 1991-2007?

2) What was the institutional context in which Croatian journalists acted, and how it shaped the journalistic writings about the Yugoslav past? How did the Croatian journalists use the Yugoslav past, and whose perspectives on the past were available from the Croatian mainstream and oppositional newspapers in 1991-2007?

3) What were the factors contributing to persistence or malleability of the Yugoslav past in the Croatian history textbooks and newspapers?

\subsection{METHODS}

The present chapter examines main uses of the Yugoslav past in the educational system and in the media in the post-Yugoslav Croatia. I used secondary sources to identify characteristics of the educational and media historical-institutional context in the 1990s and the 2000s. For uses of the Yugoslav past, I analyzed history textbooks and selected newspapers in 1991-2007 (see the previous chapter and Appendices A and B for details). I used each textbook as a unit of analysis and I examined how each textbook presented the communist Yugoslavia. The analysis of newspapers used articles as units of analysis. All Yugoslavia-related articles and articles on current topics with references to Yugoslavia were coded for the main topic, for the speaker (e.g. journalist or historian or official), for the type of article (e.g. interview or report from commemorative event) or for the function (see below) of the past in the article. The present analysis also examined the World-War-Two related articles, but these articles were coded only for the topic, and they were coded for the article function only if there was a direct reference to 
the communist Yugoslavia or to Tito.

The function of the past in the article was based on Edy's (1999, 2006) and Zelizer’s (2008) differentiations between different types of articles about the past and on my expansion of these categories. Therefore, articles were classified into the following categories:

(1) Commemoration: anniversaries, obituaries, revisits of some past-related topics.

(2) Historical context: either explicit, where the article uses the past to contextualize a current state of affairs; or implicit, where the article is a reaction to some past-related public debate, or to some newly published book about the past, or to some non-commemorative current event that evokes associations to a past topic. The implicit context also includes some apparently unprompted testimonies or the revisits of particular Yugoslav events or periods.

(3) Historical analogue: articles in which a topic is interpreted by referring to the past, either by implying similarity between the past and the present events or by comparing them explicitly. (4) Ironic Revisit: special category unique to the satirical weekly Feral Tribune, where the text is satirical in tone or it contains re-publication of the text written by some currently prominent individual in the Yugoslav period.

(5) Aside: reference to an element of the Yugoslav past which is not necessary to the article and which is often included only as a point of parenthetical interest.

In the following analyses, I first examine how the Yugoslav past was used in history textbooks and newspapers in 1991-2007, with special attention to institutional context. Next, I focus on journalistic uses and the forms in which they presented the Yugoslav past and how this may have affected collective memories. Finally, I also analyze those aspects of the Yugoslav past that were most changed in textbooks and newspapers and those that remained persistent, and I attempt to identify factors that contributed to such uses of the past. 


\subsection{USES OF THE YUGOSLAV PAST IN EDUCATIONAL SYSTEM AND THE MEDIA}

\subsubsection{Influence of Historical-Institutional Context and Main Actors in the Croatian Post- Yugoslav Educational System and Media on Institutionalized Frames}

\subsubsection{Teaching History in the Croatian Context in the 1990s}

The Yugoslav communist regime, similarly to the GDR regime (Dierkes 2010), used Communist Party cadres to control history curriculum and history textbooks. History education served ruling elite interests' by presenting an exclusively Marxist interpretation of history and by legitimizing the Communist Party rule (Höpken 1997; Goldstein 2008). For example, Yugoslav textbooks glorified the role of the Communist Party and its leader Josip Broz Tito in World War Two. Their antifascist struggle and resistance against the Nazi occupation and the collaborator governments legitimized Communist's power after the war. The new Yugoslav national identity transcending particular identities of the Yugoslav peoples (Höpken 1997). However, as each of six Yugoslav Republics published their own history curriculum and textbooks, interests of each Republic's ruling elites also played a role in directing history education. Therefore, while sharing the official celebration of the Yugoslav identity, each Republic’s textbooks were different enough to preserve distinct national discourses (Koren, personal communication, June 19, 2012). Nevertheless, whether at level of the state or at level of federal republics, the Yugoslav communist regime, similarly to other communist regimes, was characterized by an instrumental and politically-controlled approach to history education, which explicitly espoused interests of ruling elites through the centralized history curriculum and its prescribed textbooks. Teachers were not allowed to deviate from these very strict guidelines (Najbar-Agičić 2006).

The collapse of the communist regime and the disintegration of Yugoslavia in 1991 brought an abrupt break with history education of the previous regime in terms of content. Celebration of communism/socialism and Yugoslavia was replaced with celebration of the new 
Croatian nation-state, which defined itself as democratic and capitalist. However, in terms of educational policies, the break with practices of the previous regime was not so dramatic. The newly independent Croatia was under rule of the Croatian Democratic Community (Hrvatska demokratska zajednica - HDZ) headed by President Franjo Tudjman. Although formally a democracy, 1990s Croatia was a hybrid between an authoritarian regime and a formal democracy (Ottaway 2003). In this regime, authority of President Tudjman was supreme, and Tudjman was by profession a historian who based legitimacy of his rule on the grand national narrative of Croatian statehood achieved after centuries of oppression (Goldstein 2001, 2008). In addition, during the first half of 1990s, Croatia fought a war for independence from Yugoslavia on its territory, which further fueled Tudjman’s politics of nationalism. Therefore, Tudjman displayed a particular interest in history and his subordinates used their political power to preserve the control over textbooks (Goldstein 2001).

This was achieved in the following ways. The history curriculum and the textbook approval system remained centralized under the Ministry of Education ${ }^{11}$, and political pressures to preserve Tudjman's vision of history resulted in bureaucratic and even censuring interventions into the textbook approval process (Höpken 2007). In fact, the Ministry of Education established an office of the Special Consultant for History Education and this one person made final decisions about both history curriculum and approved history textbooks (Koren and Baranović 2009). Further, the history curriculum and the first Croatian history textbooks were written by people loyal to Tudjman’s government (Najbar-Agičić and Agičić 2007) who believed strongly that history education should serve the Croatian national identity (Koren and Baranović 2009). As I demonstrate later, these initial developments established guidelines for writing textbooks

\footnotetext{
${ }^{11}$ The Ministry of Education underwent several organizational and name changes (the latest is the Ministry of Education, Science and Sport), but for simplicity, I will to refer to it as "Ministry of Education”.
} 
from which authors that came later could not easily deviate.

Early in Tudjman's rule, the textbooks of the Socialist Republic of Croatia were pulled from schools, but - amidst the Homeland War - they were not readily replaced by new Croatian textbooks. Instead, teachers relied on the Ministry of Education guidelines in their teaching. The textbook problem was particularly evident in vocational high schools where it took five years to introduce a new history textbook. In contrast, the textbook gap was considerably smaller in primary schools and college-track high schools where new history textbooks appeared in, respectively, 1992 and $1993 .{ }^{12}$ The first Croatian history curriculum was published in 1991, and this curriculum brought reform only insofar that it removed the Marxist framework of historical interpretation and introduced the new framework of the Croat-centric history (Koren 2003). Pedagogically, however, the new Croatian textbooks were very similar to the Yugoslav textbooks. Similarly to the Japanese case described by Dierkes (2010), presentation of history in the new Croatian textbooks remained chronological, prescriptive and with a heavy emphasis on historical details, primarily requiring students to memorize information. This is a trend that would continue in later Croatian curricula as well (Koren 2003).

Therefore, the first Croatian textbooks were similar to their Yugoslav predecessors: they were heavily ideologized and served as mouthpieces for President Tudjman's vision of history and for ruling party's interests. While the Yugoslav textbooks touted Yugoslavia as a salvation of the (Yugo-)Slav nations from their oppressive neighbors and glorified communism and Tito, the new textbooks propagated the idea of CROATIAN VICTIMIZATION and Croatian oppression on the hand of its neighbors (defining Yugoslavia as a period of oppression). They also claimed that the centuries-long dream of statehood that was realized in Tudjman's Croatia

\footnotetext{
${ }^{12}$ This does not include the heavily edited last edition of the 8th grade Yugoslav history textbook published in 1991, which contained a mixture of the Yugoslav ideology and the new text obviously written as an approving response to the political changes in Croatia. This textbook was pulled from schools after only one semester in use.
} 
(Höpken 1997; Najbar-Agičić and Agičić 2007; Koren 2003, 2005, 2007). Furthermore, two elements of Tudjman's nationalist agenda were particularly prominent in public discourse, and both of these were reflected in textbooks. The first was momentum towards forgetting or denying the Yugoslav identity, and the second was revisionist approach to World War Two and the Nazicollaborators Ustasha and their short-lived Independent State of Croatia (Nezavisna Država Hrvatska - NDH) (Bellamy 2003).

The first textbooks dutifully followed both dismissal of Yugoslav identity and revisionist approach to the Second World War. First, 45 years of the communist rule were presented through fewer lessons than the NDH and the Second World War. ${ }^{13}$ In addition, lessons on Yugoslavia were mostly written through prism of Croatia's suffering on its path towards statehood and used a strong language decrying Great Serbian hegemonic rule and the Serbian exploitative treatment of the Croats. Next, substantial amount of the text dedicated to the NDH was clearly apologetic (Bellamy 2003; Goldstein 2001) - the textbooks relativized the Ustasha crimes and emphasized NDH's continuity with the Croatian statehood (Goldstein 2001, 2008). At the same time, communist Partisans’ war crimes were presented in great detail (Goldstein 2001) and some textbooks preferred to speak of "antifascists" and avoid mention of "Partisans" when describing the resistance movement.

Because of institutional developments that followed, the pattern established by the first textbooks continued to exert its influence in the whole period under review. In a move unusual in practice of the history curriculum creation (Koren 2005), the new 1995 history curriculum, prepared by the Ministry of Education’s Special Consultant for History Education, used the first textbooks as models (Koren 2005; Najbar-Agičić and Agičić 2007; Koren and Baranović 2009).

\footnotetext{
${ }^{13}$ Although, heavy focus on World War Two (which was actually reduced now) and considerably smaller focus on Yugoslavia were typical of socialist textbooks as well. The treatment of the NDH, however, was new.
} 
Since the elaborately prescriptive 1995 curriculum is practically still in effect ${ }^{14}$, this resulted in most of the examined history textbooks sharing not only a very similar structure, but also similar titles and subtitles with lessons on Yugoslavia in the 1992 Perić's 8th grade textbook (Koren 2005; Najbar-Agičić and Agičić 2007), as can be seen from Table 3.1.

Table 3.1: Lessons on the Communist Yugoslavia in the 1992 Perić's 8th Grade Textbook

\begin{tabular}{|c|c|c|}
\hline Lesson Title & Subtitles & Comments \\
\hline \multirow{5}{*}{$\begin{array}{l}\text { Croatian Decades } \\
\text { within the Socialist } \\
\text { Yugoslavia (I)* }\end{array}$} & $\begin{array}{l}\text { AVNOJ Yugoslavia becomes Federal } \\
\text { Republic }\end{array}$ & $\begin{array}{l}\text { Focus on non-democratic nature of the } 1945 \\
\text { elections that put the Communists in power. }\end{array}$ \\
\hline & Socialist Regime and Its Opponents & \\
\hline & $\begin{array}{l}\text { From ZAVNOH to the Croatian } \\
\text { Sabor (Parliament) }\end{array}$ & $\begin{array}{l}\text { Establishes continuity of the Croatian statehood } \\
\text { through the institution of the Croatian Parliament } \\
\text { during the Yugoslav period. }\end{array}$ \\
\hline & $\begin{array}{l}\text { The Shackles that Bound the Croats } \\
\text { and Croatia }\end{array}$ & $\begin{array}{l}\text { Changed into "The Subordinate Position of } \\
\text { Croats and Croatia in the FNRJ" in Perić's1993 } \\
\text { edition for college-track high school, which is the } \\
\text { subtitle adopted by most other authors. }\end{array}$ \\
\hline & $\begin{array}{l}\text { Ruling Regime’s Relationship } \\
\text { Towards Religious Communities }\end{array}$ & $\begin{array}{l}\text { Focus on the Catholic Church and the communist } \\
\text { persecution of the Catholic Archbishop Stepinac. }\end{array}$ \\
\hline \multirow{3}{*}{$\begin{array}{l}\text { Croatian Decades } \\
\text { within the Socialist } \\
\text { Yugoslavia (II)* }\end{array}$} & $\begin{array}{l}\text { Conflict with the USSR and the } \\
\text { Necessity of Political Independence }\end{array}$ & \\
\hline & $\begin{array}{l}\text { Outside the Political-Military } \\
\text { Alliances }\end{array}$ & Reference to the Non-Aligned Movement. \\
\hline & $\begin{array}{l}\text { Croatia under Burden of Centralism } \\
\text { and Unitarism }\end{array}$ & $\begin{array}{l}\text { Includes discussion of agricultural reform after } \\
\text { the Second World War, which is a separate } \\
\text { subsection in Perić's1993 edition for college- } \\
\text { track high schools and many other later } \\
\text { textbooks. }\end{array}$ \\
\hline \multirow{2}{*}{$\begin{array}{l}\text { Croatian Decades } \\
\text { within the Socialist } \\
\text { Yugoslavia (III)* }\end{array}$} & $\begin{array}{l}\text { Developmental Problems and the } \\
\text { Internal Political Turmoil }\end{array}$ & $\begin{array}{l}\text { Reference to political and economic crises in the } \\
\text { early 1960s. }\end{array}$ \\
\hline & $\begin{array}{l}\text { Croatia Demands the Politics of } \\
\text { "Clean Accounts" and the Regime's } \\
\text { Reaction to This }\end{array}$ & $\begin{array}{l}\text { Focus on the Croatian political, economic and } \\
\text { cultural movements of the 1960s/1970s. }\end{array}$ \\
\hline *Period 1965-1989 & Croats Outside the Homeland & $\begin{array}{l}\text { Focus on the Croatian political and economic } \\
\text { emigrants. }\end{array}$ \\
\hline $\begin{array}{l}\text { Collapse of the } \\
\text { Communist } \\
\text { Socialism and the } \\
\text { Communist Party } \\
\text { Onemind Thinking }\end{array}$ & $\begin{array}{l}\text { Weaknesses Which the Socialist } \\
\text { Yugoslavia Could Not Survive }\end{array}$ & $\begin{array}{l}\text { One section on collapse on Yugoslavia within the } \\
\text { lesson on collapse of the socialist systems in the } \\
\text { Central and Eastern Europe. }\end{array}$ \\
\hline
\end{tabular}
${ }^{14}$ At the time of writing, the 1995 history curriculum, slightly modified, is still in force for high schools. Primary
schools have used a new curriculum since 2006, but it is still mostly based on the 1995 curriculum (Koren 2007). 
Even a cursory examination of main topics of Perić's lessons on Yugoslavia (see Table 3.1 above) reveals focus on elements comprising Tudjman’s nationalist agenda. This includes narrative of the continual Croatian statehood, Croatian victimization in Yugoslavia, the supposed link between the Croatian identity and the Roman Catholic faith and celebration of Croatian emigrants, who were the backbone of Tudjman's support base in the 1990s (Bellamy 2003). This supports the claim of strong influence of Tudjman's ruling party on classroom presentations of Yugoslavia.

Nevertheless, after the war ended in 1996, the challenging voices from historians' circles gained in strength and some changes occurred. Most significant was a new regulation allowing more than one textbook per grade, which was introduced in 1996 (Goldstein 2001; Koren and Baranović 2009). However, this practice of parallel textbooks was at first limited - it was only in 1998 that teachers were allowed to freely choose their textbooks, instead of one being assigned to them based on publishers' quotas (Goldstein 2001; Koren and Baranović 2009). Furthermore, competition between parallel textbooks in the late 1990s was, at best, perfunctory. The same author (Perić) published only slightly edited versions of his old textbooks for the 8th grade and college-track high schools with a different publisher. Until 2000, there were no other available 8th grade textbooks, and the first parallel textbook for college-track high schools, which appeared in 1998 by another author (Vujčić), closely followed the lead of his predecessor in structure and content, but used even more ideologized language. For an illustration, consider the following excerpts from three textbooks in the 1990s in Table 3.2. 
Table 3.2: Equivalent Excerpts from Three History Textbooks in the 1990s

\begin{tabular}{|c|c|c|}
\hline $\begin{array}{l}\text { Perić, 1992: } \\
\text { Textbook for the 8th grade of the } \\
\text { primary school }\end{array}$ & $\begin{array}{l}\text { Perić, 1997: } \\
\text { Textbook for the 4th grade of the } \\
\text { college-track high school }\end{array}$ & $\begin{array}{l}\text { Vujčić, 1998: } \\
\text { Textbook for the 4th grade of the } \\
\text { college-track high school }\end{array}$ \\
\hline $\begin{array}{l}\text { From the subsection titled "The } \\
\text { Chains that Bound the Croats and } \\
\text { Croatia", pg. 129/130 } \\
\text {...In order to even more bind and } \\
\text { disable Croats, they were unjustly } \\
\text { and tendentiously blamed for the } \\
\text { Ustasha war crimes. The number of } \\
\text { Ustasha victims was so exaggerated } \\
\text { that it seemed that only in Jasenovac } \\
\text { more Serbs were killed than there } \\
\text { were human casualties during the war } \\
\text { in entire Yugoslav area. Although the } \\
\text { Croats were the most numerous } \\
\text { participants in the antifascist armed } \\
\text { struggle (1941-1945), including } \\
\text { struggle against the Ustasha, this fact } \\
\text { was intentionally dismissed. Many } \\
\text { Croats, including the Communist } \\
\text { Party members, were distrusted and } \\
\text { they advanced more slowly in the } \\
\text { army, they had difficulties in } \\
\text { obtaining managerial positions in } \\
\text { federal agencies of internal affairs, } \\
\text { and they rarely could become consuls } \\
\text { and ambassadors of the FNRJ. In the } \\
\text { FNRJ, which guaranteed national } \\
\text { equality, the Serbs were "more } \\
\text { equal” (privileged). }\end{array}$ & $\begin{array}{l}\text { From the subsection titled "The } \\
\text { Subordinate Position of the Croats } \\
\text { and Croatia in FNRJ”, pg. } 202 \\
\text {...Many Croats, even if members of } \\
\text { the Communist Party, were } \\
\text { distrusted and they advanced more } \\
\text { slowly in the army, they had } \\
\text { difficulties in obtaining managerial } \\
\text { positions in federal agencies for } \\
\text { internal affairs, and they rarely } \\
\text { could become consuls and } \\
\text { ambassadors of FNRJ. Even though } \\
\text { the FNRJ guaranteed national } \\
\text { equality, the Serbs were more } \\
\text { privileged, they had the advantage. } \\
\text { In order to even more bind and } \\
\text { disable Croats, the Serbian circles } \\
\text { constantly blamed them for the } \\
\text { Ustasha war crimes. For this } \\
\text { reason, the number of Ustasha } \\
\text { victims was always exaggerated. } \\
\text { This tendentious exaggeration went } \\
\text { so far that it was claimed that in } \\
\text { Jasenovac more Serbs were killed } \\
\text { than there were human casualties } \\
\text { during the war in entire Yugoslav } \\
\text { area. }\end{array}$ & $\begin{array}{l}\text { From the subsection titled "The } \\
\text { Subordinate Position of the Croats } \\
\text { and Croatia in FNRJ", pg. 198/199 } \\
\text { Great Serbian politics, on federal } \\
\text { and republic levels, unfairly } \\
\text { blames the Croats for the Ustasha } \\
\text { and the Domobrans, for genocide } \\
\text { and the war crimes. The numbers } \\
\text { and the contributions of the } \\
\text { Croatian antifascists in the war are } \\
\text { ignored. The Croatian communists } \\
\text { have difficulties obtaining higher } \\
\text { federal state positions because they } \\
\text { are distrusted and because these } \\
\text { positions are intended for the Serbs } \\
\text { in Croatia. Equality is formally } \\
\text { guaranteed by the Constitution, but } \\
\text { the equality does not exist in } \\
\text { practice in Croatia because the } \\
\text { Serbs are "more equal” than the } \\
\text { Croats. They, compared with the } \\
\text { Croats, are in the privileged } \\
\text { positions when it comes to the } \\
\text { employment, managerial political } \\
\text { and economic positions, } \\
\text { scholarships, etc. } \\
\text { (emphasis in original) }\end{array}$ \\
\hline
\end{tabular}

Furthermore, vocational textbooks are neglected even by academic circles - among many

existing analyses of Croatian history textbooks, not one includes vocational textbooks. In the 1990s, therefore, vocational textbook authors could produce even more ideologized presentations of history without being called upon it. The 1990s vocational textbooks not only wrote much less about Yugoslav history than other textbooks ${ }^{15}$, but this text was further selected so it emphasized even more the frame of CROATIAN VICTIMIZATION on hands of the Serbs. In addition, per the curriculum's prescriptions, the first vocational textbook by Vujčić in 1996, left out some positive descriptions of Yugoslavia (such as resistance to Stalin or the Non-Aligned Movement),

\footnotetext{
${ }^{15}$ For example, the Yugoslav period 1945-89 got 11 and 14 pages, respectively, in a 8th grade and a college track textbook in the 1990s, and only four and five pages in two vocational school textbooks.
} 
and added a section about Croatian Catholic saints. The latter, for example, clearly supported nationalistic discourse of the period juxtaposing the Croatian national identity with its Roman Catholic tradition. In all other aspects, the 1996 Vujčić's textbook emulated the 8th grade Perić's textbook. Two other vocational textbooks that become parallel to the Vujčić's textbook in 1997 and 1998 used milder language and fewer details on all ways in which the Croats were victimized, but they were similar in structure and messages, and even some specific formulations of the text. For an illustration, consider the following excerpts in Table 3.3.:

Table 3.3: Equivalent Excerpts from Three Vocational History Textbooks in the 1990s

\begin{tabular}{|c|c|c|}
\hline $\begin{array}{l}\text { Vujčić, 1996: } \\
\text { Textbook for the 3-year vocational } \\
\text { high school }\end{array}$ & $\begin{array}{l}\text { Mirošević et al., 1997: } \\
\text { Textbook for the 4-year vocational } \\
\text { high school }\end{array}$ & $\begin{array}{l}\text { Đurić \& Peklić, 1998: } \\
\text { Textbook for the 3-year vocational } \\
\text { high school }\end{array}$ \\
\hline $\begin{array}{l}\text { From subsection titled "The } \\
\text { Subordinate Position of the Croats } \\
\text { and Croatia in the Second } \\
\text { Yugoslavia”, pg. } 208 \\
\text { Similarly to the first Yugoslavia, the } \\
\text { position of the Croats and Croatia } \\
\text { was inferior compared with the } \\
\text { Serbs in the second Yugoslavia as } \\
\text { well. This was also due to the unfair } \\
\text { burden of the Ustasha and the war } \\
\text { crimes. The victims of these crimes } \\
\text { were greatly exaggerated, of course, } \\
\text { unfairly, in order to present the } \\
\text { Croats as criminal, fascist and } \\
\text { genocidal people to the Yugoslav } \\
\text { and world public. The real historical } \\
\text { truth about the Croats was hidden } \\
\text { from the public. The burden of the } \\
\text { Ustasha and the Domobrans was } \\
\text { also shouldered by families of these } \\
\text { soldiers. Members of these families } \\
\text { were suspect, they had difficulties } \\
\text { getting employments or getting } \\
\text { scholarships for their children's } \\
\text { education. There were few Croats in } \\
\text { high-ranking civil services. High and } \\
\text { lucrative positions were reserved for } \\
\text { the Serbs. The Serbian people were } \\
\text { privileged over the Croats in every } \\
\text { area. The politically unsuitable } \\
\text { Croats were ostracized. } \\
\text { (emphasis in original) }\end{array}$ & $\begin{array}{l}\text { From subsection titled "The } \\
\text { Subordinate Position of the Croats", } \\
\text { pg. } 238 / 239 \\
\text { The established social and political } \\
\text { system in the post-war Yugoslavia } \\
\text { caused a lot of dissatisfaction in } \\
\text { Yugoslavia, but this was not } \\
\text { expressed publicly in fear from } \\
\text { persecution. It is estimated that } \\
\text { around 100,000 Croats were } \\
\text { condemned to death and long- } \\
\text { serving prison sentences in the post- } \\
\text { war years, their property was taken } \\
\text { away and they were persecuted in } \\
\text { various ways. The Croats were } \\
\text { constantly and maliciously blamed } \\
\text { for actions of the Ustasha, their } \\
\text { antifascist participation was } \\
\text { neglected and ignored. Many Croats, } \\
\text { including the Croatian communists, } \\
\text { were distrusted, they had difficulties } \\
\text { in obtaining managerial positions at } \\
\text { the federal level, in agencies of the } \\
\text { internal affairs, in the military and } \\
\text { diplomacy. Privileging the Serbs in } \\
\text { the civil services was visible in } \\
\text { Croatia as well. }\end{array}$ & $\begin{array}{l}\text { From subsection titled "The } \\
\text { Subordinate Position of the Croats } \\
\text { and Croatia in the Second } \\
\text { Yugoslavia", pg. } 149 \\
\text {...The Croats were blamed for the } \\
\text { crimes committed by the Ustasha. } \\
\text { Few Croats were in the military and } \\
\text { diplomacy. The Croats were often } \\
\text { persecuted for expressing Croatian } \\
\text { patriotic feelings and singing } \\
\text { Croatian national songs. }\end{array}$ \\
\hline
\end{tabular}


The above analysis of institutional context and developments in history education suggests that the ruling elites in the 1990s used the Croatian centralized educational policy-making regime as a political instrument. They misused their power to impose their national narrative on the Yugoslav past as the only perspective to be presented to students in schools. This narrative, predominantly framed by the view of CROATIAN (ETHNIC) VICTIMIZATION (presented in the previous chapter) did not allow any complexities or any challenges to presentations of the Yugoslav past. In addition to CROATIAN (ETHNIC) VICTIMIZATION, all other available textbook presentations of Yugoslavia in the 1990s focused purely on its political and economic aspects, which were all explicitly interpreted by textbook authors as extremely negative and harmful to the Croats.

Further, since this analysis demonstrated influence of the ruling elites on the dominant textbook presentations of Yugoslavia, these presentations can be used as indicators of "official" narratives of the Yugoslav past in that period. However, although history education is certainly one of the most powerful instruments for transmitting certain perspectives on the past to other groups in society, it is not the only source of narratives "from above”. Another important source is the media. Therefore, next I examine how the Croatian media in the 1990s, and journalists in particular, played out their role as producers of collective memories and potential allies or challengers to the ruling political elites.

\subsubsection{The Media and Newspaper Discourse on the Communist Yugoslavia in the 1990s}

The 1990 transition from communist Yugoslav to formally democratic Croatian regime lifted strict communist restrictions on media freedoms, but, paradoxically, it also brought an end to liberalizing media developments characterizing the last years of Yugoslavia. The first Croatian Constitution guaranteed freedom of expression and forbade censorship. In addition, the newly 
introduced market capitalism enabled privatization and proliferation of newspapers and magazines (Malović and Selnow 2001). This contrasted markedly with the Yugoslav period. Although Yugoslav softer socialism and occasional bouts of liberalization were well-reputed, communist leadership still controlled the media (Malović and Selnow 2001). This control, however, started slipping in the decade between Tito's death in 1980 and the break-up of Yugoslavia, as the Yugoslav Republics started squabbling for power and pushing forward their national agendas. Journalists were still in service of Communist Party officials, but they were now divided along federal lines (Malović and Selnow 2001). These divisions weakened the central control which eased restraints on journalists.

However, such developments were arrested with the rightist HDZ and Franjo Tudjman coming to power in the first multiparty elections in 1990 and the war breaking out in Croatia in 1991. The first measures limiting freedom of speech were introduced as wartime necessities, and although these were quickly lifted, they set up a restrictive framework that characterized the rest of Tudjman's rule (Malović and Selnow 2001). This included both restrictive legal framework and administrative and technical restraints, such as controlling the national TV concession, concentrating people loyal to Tudjman in the management and editorial boards or obstructing distribution of offending newspapers (Malović and Selnow 2001; Ottaway 2003).

For example, both mainstream newspapers examined in the present study were linked to the ruling party. The high-brow Vjesnik was majority state-owned and heavily state-subsidized (Malović 2004; Croatian Parliament 2006). Privatization of the widely circulated Večernji list was not allowed before 1997 when it was sold to a Virgin Island firm with unknown owners, although it was a public secret that it was HDZ-controlled ${ }^{16}$ (Malović and Selnow 2001; Malović

\footnotetext{
${ }^{16}$ In 2001 the Večernji list was sold to an Austrian company Styria (Malović 2004).
} 
2004; Jurišin 2002). Therefore, in the 1990s both the only TV station with the national concession and the mainstream print media were, to a degree, under control of people close to the ruling elites and President Tudjman.

Oppositional media space in this period existed, but it was limited. For example, the two oppositional newspapers in the present study were extraordinary in preserving their independence. The regional Novi list was one of the first privatized newspapers, with journalists as controlling shareholders, and the weekly Feral Tribune, founded by dissident journalists in 1993, also remained in private ownership until it went under in 2008 (Malović and Selnow 2001; Jurišin 2002).The Feral Tribune also exemplified misuses of legal framework by the ruling party. Being the Government's most outspoken critic, the Feral Tribune spent most of the 1990s in court, and in 1999 it owed more than two million dollars in legal costs from libel or mental anguish suits, with more than a hundred cases still in trial (Ottaway 2003). In addition to these obstacles, these oppositional newspapers' circulation numbers limited their reach - the Novi list was a regional newspaper and the Feral Tribune catered primarily to a smaller audience of mostly oppositional intellectuals.

Therefore, the ruling elites in the 1990s retained control not only over the educational system, but also over most of the media via their control of the only national TV station and of the major newspapers such as the Vjesnik and the Večernji list. Further, space in which the oppositional media, such as the regional Novi list or the independent weekly Feral Tribune, could act was limited with a series of administrative, technical and legal obstacles, as well as with their smaller circulation numbers.

Such an institutional context with a high degree of state control over the media in the 1990s suggests that the mainstream newspapers, similarly to the historical textbooks, should 
present the Yugoslav past in ways consistent with President Tudjman's interpretation of history and ruling party's public agenda. This certainly seems to be the case with disproportional focus on the fascist collaborator Ustasha regime and the Communist Partisans' crimes in the Second World War and the simultaneous much smaller attention to the Yugoslav period that characterized both the 1990s history textbooks and public discourse in this period. During the critical discourse moments in the 1990s, the examined Croatian newspapers featured a relatively small number of articles about the Yugoslav past, at least when compared with articles related to the Second World War, which were almost twice as numerous (see Table 3.4).

Table 3.4: Articles in the Critical Discourse Moments, all newspapers

\begin{tabular}{|c|c|c|c|c|}
\hline \multicolumn{2}{|c|}{ Topic } & $\begin{array}{c}\text { Yugoslavia as central } \\
\text { or constituent topic }\end{array}$ & $\begin{array}{l}\text { Current/Other with } \\
\text { reference to Yugoslavia }\end{array}$ & $\begin{array}{l}\text { World War Two \& } \\
\text { Partisans' Crimes }\end{array}$ \\
\hline \multicolumn{2}{|c|}{$\begin{array}{c}\text { Number of articles } \\
\text { (1991-99 / 2000-07) }\end{array}$} & 313 & 104 & 578 \\
\hline \multirow{5}{*}{ 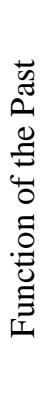 } & Commemoration & $\begin{array}{c}118 \\
(33 / 85)\end{array}$ & $\begin{array}{c}11 \\
(4 / 7)\end{array}$ & $\mathrm{n} / \mathrm{a}$ \\
\hline & Context & $\begin{array}{c}163 \\
(80 / 83)\end{array}$ & $\begin{array}{c}22 \\
(16 / 6)\end{array}$ & $\mathrm{n} / \mathrm{a}$ \\
\hline & Analogue & $\begin{array}{c}6 \\
(3 / 3)\end{array}$ & $\begin{array}{c}33 \\
(6 / 27)\end{array}$ & $\mathrm{n} / \mathrm{a}$ \\
\hline & Aside & $\begin{array}{c}15 \\
(1 / 14)\end{array}$ & $\begin{array}{c}35 \\
(6 / 29)\end{array}$ & $\begin{array}{c}79 * \\
(36 / 43)\end{array}$ \\
\hline & Ironic Revisit & $\begin{array}{c}8 \\
(7 / 1)\end{array}$ & - & $\mathrm{n} / \mathrm{a}$ \\
\hline
\end{tabular}

Furthermore, topics of articles published by two mainstream newspapers, the Večernji list and the Vjesnik, in this period included mainly political and economic re-evaluations of the Yugoslav period with focus on CROATIAN VICTIMIZATION. These articles, for example, talked from perspective of ethnic victimization about Croatian statehood, suppression of the Croatian culture or identity, the nationalist/reformist movements of the 1960s/1970s, exploitation of Croatia in Yugoslavia, fate of certain prominent Croatian individuals and communist persecutions, political trials and political prisoners. This, again, reflects the frame of CROATIAN (ETHNIC) VICTIMIZATION that dominated history textbooks in the 1990s and it 
further supports the claim that "official" narratives of the ruling elites were established in the mainstream newspaper discourse in the 1990s. From this viewpoint, Yugoslavia was an obstacle on path towards Croatian statehood and the Yugoslav break-up was mainly interpreted as Croatian national emancipation.

The oppositional newspapers, the regional daily Novi list and the radical weekly Feral Tribune, also mainly interpreted Yugoslavia negatively in political and economic terms in the 1990s, but focus of some of oppositional newspaper articles shifted subtly from stories of Croatian victimization to stories of problems, flaws and failures of the Yugoslav system. Therefore, rather than employing the CROATIAN (ETHNIC) VICTIMIZATION frame, discussions of ethnic and republic problems employed other, somewhat milder, ethnic frames (FALSE FEDERAL ORGANIZATION, YUGOSLAV UNITY VIOLATED NATIONAL RIGHTS or NATIONAL INEQUEALITY). In addition, from this viewpoint, Yugoslavia was discussed as a problematic system and the Yugoslav break-up was mainly interpreted as an emancipation from a non-democratic and (poorly functioning) non-capitalistic regime, as opposed to predominantly discussing Yugoslavia as an obstacle on path towards Croatian statehood and the Yugoslav break-up as Croatian national emancipation, which was focus of the 1990s textbooks and mainstream newspapers in their emphasis on the CROATIAN (ETHNIC) VICTIMIZATION frame. For ease of reference, then, in the rest of the text I will refer to the latter as the Croatian Ethnic Victimization Viewpoint, and to the former as the Flawed Yugoslav System Viewpoint.

In this Flawed Yugoslav System Viewpoint, which found its place in some oppositional newspaper articles, discussions of problems of the Yugoslav system/socialism were sometimes presented from perspective of people more rarely, if ever, featured in the mainstream 
newspapers. This included leftist intellectuals or former Yugoslav officials or even, in one instance in the Feral Tribune, a Serbian dissident. Likewise, another rare perspective featured in the oppositional Novi list was that of reformist Croatian communists who were given a chance to defend their position in the events of the 1960s/1970s against the position of more radical members of the same movement, the nationalist protagonists, whose perspective dominated the mainstream newspaper accounts.

On a final note, although numbers of the Yugoslavia-related articles published in the 1990s in all four newspapers were similar (30-40 articles in each mainstream newspaper and 20-30 in each oppositional newspaper), around a third of such articles published in the oppositional Feral Tribune in the 1990s were satires or re-published older articles in which some individuals (President Tudjman, for example) praised Tito or the Yugoslav system they now vilified. Therefore, such articles used the Yugoslav past as an instrument for political criticism by exposing hypocrisy of the ruling elites and their supporters, who routinely used condemnation of all things Yugoslav to legitimize their power and to discredit their political competitors, and whose views were generously represented in the mainstream newspaper discourse in the 1990s.

At the end of the 1990s, however, the media space in Croatia started transforming, which is a development accompanying the growing strength of the Croatian civil society. In 1998 and 1999 several NGOs, supported by many Croatian public figures, campaigned for citizens to vote (“against the HDZ” was implied) in the upcoming 2000 parliamentary elections. In light of this, even the bickering and fragmented opposition organized into a coalition in order to oust the HDZ. Changes were occurring in press as well. They peaked in some forty days preceding Tudjman's death in December 1999 when several newspapers covered previously hushed-up topics, such as the HDZ-related scandals, their political blunders, and, last but not least, 
Tudjman's medical situation (Malović and Selnow 2001). All these events anticipated the democratizing changes of post-Tudjman Croatia, which I detail in the next section.

Further, possibly an indicator of growing freedoms, the newspaper discourse in the late 1990s is characterized by one development that deviates from ruling elites' treatment of Yugoslavia. This is a prominent re-appearance of discussions of Yugoslav late President Tito, which started appearing mainly in reports from commemorations of Tito's birthday in his birthplace Kumrovec. These commemorations were institutionalized in the Yugoslav regime as a part of a state holiday called the "Day of Youth". The official commemoration of this day in Kumrovec stopped with the Yugoslav break-up, but it survived unofficially throughout the 1990s as individual visitors and occasional smaller groups continued to visit on Tito's birthday (Rajković 2006). At the end of the 1990s, numbers of visitors started increasing ${ }^{17}$, thus attracting journalists’ attention (Rajković 2006).

In the mainstream newspapers, resurgence of the topic of Tito is particularly conspicuous compared with its absence in the early 1990 s. ${ }^{18}$ During the early 1990 s, Tito made rare appearances in oppositional newspapers as well, but he was treated slightly differently. In the Novi list, for example, one can find references to his contributions, and not only to his negative re-evaluations, and these references, although few and far between, pre-dated Tito’s great reappearance in reports from commemorations that occurred in the Novi list in the late 1990s as well. The Feral Tribune, however, deviates from pattern of both mainstream newspapers and the Novi list. The topic of Tito is used almost exclusively to criticize both the Croatian public ${ }^{19}$ and

\footnotetext{
${ }^{17}$ In the 2000s this will lead to renewed and well attended commemorations of Tito's birthday and death.

${ }^{18}$ In the early 1990s, only two articles about Tito appeared in the examined mainstream newspapers: one talked about Tito's luxurious life and the other reported demands for changing the name of Tito's Square located in the Croatian capital, Zagreb (which, incidentally, was not done).

${ }^{19}$ In re-published articles and satires detailing collective grief and mourning of the Croatian people at Tito's death, which serve as counterpoints to then-current attempt of public discourse to forget about Tito.
} 
the leading politicians, and particularly President Tudjman who is compared to Tito in his dictatorial and the cult of personality aspirations. In addition, the Feral Tribune, as a weekly, did not generally publish reports from commemorative events, so the great resurgence of Tito in the late 1990s is absent from this newspaper.

Nevertheless, as the Feral Tribune's approach was unique in many aspects, resurgence of the public and the consequent journalistic interest in Tito in the late 1990s in both two mainstream newspapers and the Novi list may be taken to indicate some relaxation of newspaper discourse on the recent Yugoslav past. However, there were also other factors, related to institutional context, stakeholders' resources and characteristics of Tito's image that contributed to re-emergence and renewed continuity of Tito's memory. I will discuss these factors in the section on persistent and malleable elements of the Yugoslav past.

\subsubsection{The 2000s Changes in Teaching History and Newspaper Discourse on Yugoslavia}

In December 1999 President Tudjman died. In the aftermath of his death, the country changed. The HDZ lost both the parliamentary and the presidential elections, and the victorious oppositional coalition started many democratizing changes. In history education, the Ministry of Education preserved its centralized role in approval of textbooks, but it now exercised less control over their content (Najbar-Agičić and Agičić 2007). For example, the nomination of the Committee for Evaluation of History Textbooks in 2000, consisting mostly of academics and history teachers, prompted greater debate about textbooks and purpose of history education (Koren 2007; Koren and Baranović 2009). The Committee proposed various changes, and although few were implemented in the end (the curriculum was not changed, for example), many new textbook authors, among which a fair share were primary and secondary school teachers, started incorporating methodological innovations into their work aimed towards encouraging 
students' critical thinking about history (Koren and Baranović 2009).

In 2003, the HDZ came back to power, but without Tudjman and with the party's new aspiration of joining the European Union, Croatia for most part remained on its democratizing path. Such democratizing changes in history education, for example, included establishing the Council for National Curriculum and developing a new strategy for curriculum changes (Koren and Baranović 2009). Nevertheless, changes were slow and sometimes halted. The new curricula for secondary schools were still not developed and the 2006 curriculum for primary schools brought little change, which meant that textbook authors still basically followed the 1990s guidelines (Koren 2007; Koren and Baranović 2009). Further, in some interpretations (Koren 2007; Koren and Baranović 2009), the 2006 Textbooks Act increased possibility of political interference compared with the 2001 Textbooks Act. However, despite many of proposed changes being only partially successful and the system remaining centralized under bureaucratic supervision of the Ministry of Education, this period is characterized by an increased activity of historians, both in their analyses of unsatisfactory situation of history education and in their greater involvement with the textbook writing and approval process. Therefore, within framework of institutional constraints still in place, a new space for a critical approach to history education was created.

Tensions between remaining constraints and new critical space were reflected in types of textbooks published in this period. On the one hand, all "new generation” textbooks (starting with the 1999 textbook by Leček et al. which anticipated some changes introduced by the 2000s textbooks) were less ideological than those published during the 1990s (Höpken 2007; NajbarAgičić and Agičić 2007; Koren 2007). For example, the amount of text dedicated to the NDH and the Second World War was further reduced (Najbar-Agičić and Agičić 2007), and language 
used to present Yugoslavia was noticeably more neutral. Also, many textbooks introduced different points of view and encouraged critical thinking (Najbar-Agičić and Agičić 2007; Koren 2007). On the other hand, new textbooks were also victims of institutional inertia, most obviously demonstrated by requirement to follow very specific prescriptions of the mid-1990s curriculum. ${ }^{20}$ As a result, structure and main lessons of the new generation textbooks remained similar to their predecessors. Admittedly, more space for "deviations" was available in content of lessons (and in the "extra" source material), but whether this space was utilized or not depended on individual authors.

Some authors did not deviate from the 1990s model and continued to write textbooks reminiscent of the 1990s textbooks. Such textbooks focused on CROATIAN (ETHNIC) VICIMIZATION. For example, they dedicated more text to elements that were, within perspective of these textbooks, interpreted as victimizations of the Croatian people and prominent Croatian individuals (e.g. agricultural reform changing national structure of some regions, persecutions of the Catholic Church, victimization of Croatian emigrants...). Further, the textbooks in this strain published in 2007 continued to neglect social and cultural history of Yugoslavia, the only content innovation brought about by the 2006 curriculum for primary schools. Such authors, therefore, continued writing from the Croatian Ethnic Victimization Viewpoint, the only available textbook perspective in the 1990s.

Other authors, however, introduced new topics and new perspectives within framework of the prescribed textbook structure or by using the "extra" section and thus presenting more diverse viewpoints. Such authors, for example, gave more space to attempts at reform within the system and they usually considerably toned down perspective of specifically Croatian

\footnotetext{
${ }^{20}$ The 2006 curriculum for primary schools did not change this, although it did put a slightly greater emphasis on cultural and social history of Yugoslavia (Koren and Baranović 2009).
} 
victimization from many lessons. Further, vocational textbooks in this strain also talked about Yugoslav conflict with the USSR, although this was not prescribed by the vocational school curriculum. Thus, such authors moved away from the Croatian Ethnic Victimization Viewpoint towards the Flawed Yugoslav System Viewpoint, which was also occasionally available from the 1990s oppositional newspapers. This, to a degree, also reflects a shift away from purely instrumental or nationalist view of history education to a more critical approach.

Hence, the Croatian history education in the 2000s was is a system in transition, where influence of academics and history teachers slowly replaced domination of the ruling elites and politically suitable bureaucrats. Role of academics and teachers, however, was still limited within constraints of the centralized educational system and institutional inertia. This transitional nature was also reflected in two types of history textbooks, where one group followed the ideological guidelines of the previous regime (and presented the Croatian Ethnic Victimization Viewpoint), and the other group strived towards the new historians' professional developments (and used the Flawed Yugoslav System Viewpoint).

The Croatian media system demonstrated similar transitional nature. Despite legislative changes allowing greater media freedoms after the regime change in 2000, occasional throwbacks to earlier media control did happen (Freedom House 2002, 2004). In addition, few changes occurred in ownership structure and in control of the media outlets (Ottaway 2003), as laws regulating transparency of the media ownership remained unsatisfactorily implemented (Freedom House 2004; Malović 2004). However, compared with the 1990s, the 2000s were characterized by a considerably more relaxed media atmosphere. As a result, journalistic uses of the past "normalized" to some extent.

This can be seen from two developments. The first was the growing number of articles on 
Yugoslavia or Tito in the 2000s for all examined dailies (see Table 3.4). ${ }^{21}$ The weekly Feral Tribune, in contrast, with some 10 articles, wrote less on Yugoslavia in the 2000s than in the 1990s. But, since the Feral Tribune mainly used the Yugoslav past to expose hypocrisy of fierce anti-Yugoslav ideology of the ruling elite, it makes sense that they were less interested in this strategy with the HDZ out of power. In the examined dailies, however, increased interest in Yugoslavia may indicate relaxation of political pressures to be silent on Yugoslavia and, particularly, on Tito. Indeed, fascination with Tito increasingly featured in the 2000s newspapers and public discourse. In the words of a Croatian film director in one of articles, Tito might be loved or hated, but he is always interesting. Even in the radical weekly Feral Tribune, which published little on Yugoslavia in the 2000s, Tito got most of the spotlight.

The second "normalization" was considerable increase of commemorative articles. Although commemorations are typical and the most legitimate journalistic use of the past (Edy 2006), they were not the main form of writing about the Yugoslav past in Croatian newspapers in the 1990s. Rather, in this period, it was historical contexts - considered a rare journalistic form due to their explicitly interpretive role (Edy 2006) - that were most often used by journalists to contextualize current events and developments within framework of the Yugoslav past. Although the historical contexts remained important in the 2000s, increased use of the commemorations and decreasing importance of the historical contexts signals journalists approaching a more typical relation to the past than it was the sharper focus on the past characterizing newspapers immediately after the Yugoslav break-up. In the next section, I examine this development, and consequences it had for availability of oppositional or the minority voices in Croatian public discourse, in greater detail.

\footnotetext{
${ }^{21}$ The Vjesnik moves from about 40 articles in the 1990s to around 50 articles in 2000-2007, the Večernji list jumps from around 30 to 70 articles, and the oppositional Novi list moves from around 30 to around 60 articles.
} 


\subsubsection{Journalistic Uses of the Past and Availability of Various Perspectives}

In newspapers, presentations of the past may seem out of place. Although they are often present implicitly, journalistic uses of the past in articles other than commemorations usually fly under the radar. On the other hand, explicit uses of the past may be more frequent in authoritarian regimes is which the media is used as a propaganda tool, but in such contexts explicit journalistic presentations of the past may be distrusted.

Croatia in the 1990s was one such context in which most journalists reproduced the 1990s ruling elites' perspectives on the Yugoslav past. Alliances between journalists and ruling elites in the 1990s were most noticeable in the mainstream press, which relied most heavily on "official" discourse. The media space for oppositional or minority voices on Yugoslavia was limited. When these perspectives appeared, as the analysis below shows, they were mostly located in some of the oppositional newspaper articles.

Moreover, following elites’ nation-building agenda, Croatian journalists, particularly in the mainstream newspapers, used the Yugoslav past more and in a more explicitly evaluative manner than democratic conventions of journalists as neutral commentators would usually allow (Edy 2006). However, the Croatian journalists "solved" their problem of needing to write explicitly about the past and seemingly respecting journalistic conventions by mostly presenting the Yugoslav past through historical contexts, whose authorship was delegated to other, more “authoritative" sources.

In the 1990s, about two-thirds of all Yugoslavia-related mainstream articles and about three-fifths of the oppositional newspaper articles were historical contexts (see Table 3.4). While this is not a usual journalistic practice (Edy 2006), the Croatian circumstances allowed their legitimate use. First, this period immediately followed the Yugoslav break-up, which created a 
need for contextualization of changes in social order. Second, the nation-building project also sustained public and political interest in history. In this context, the Croatian newspapers had more space for discussion of the past events and developments, than the long-established states, such as the USA, the subject of Edy's analysis. In addition, potential conflict between historical contexts and neutral role of journalists was in the mainstream newspapers in the 1990s often solved by delegating the role of speaker to academics, protagonists or witnesses. This not only reinforced the presumed authority of such articles about the past, but it also hid journalists' evaluative work - specifically, their editorial and rarely impartial role in delegation of topics from view.

This is particularly evident from one form of explicit historical contexts that emerged in the mainstream newspapers in the 1990s. This was an excerpt from a larger text or a book, which appeared as a feature published in a series of articles. Such excerpts provided the most detailed and most evaluative descriptions of the past developments, and their "excerpt" format made them seem separate and more authoritative than run-of-the-mill journalistic articles. Also, these detailed elaborations of the past were presumed to stand on neutral authority of academics ${ }^{22}$ or on the eyewitness authority of protagonists. However, the mainstream excerpts were more likely written by people whose perspectives aligned with perspectives of the ruling elites. Therefore, these and other historical contexts mainly adhered to the Croatian Ethnic Victimization Viewpoint and described in particular Croatia’s political and economic subordinate position, persecutions of the Catholic Church or experience of political imprisonment. In fact, the historical contexts available from the mainstream newspapers contained many of the more extreme rightist or nationalist perspectives on Yugoslavia.

\footnotetext{
${ }^{22}$ This presumption was not always true. For example, at least two book excerpts published in the mainstream newspapers in the 1990s were authored by people who were introduced as academics, but who were at that moment active right-wing politicians much better known for their radical nationalism.
} 
In contrast, journalists in the oppositional newspapers less frequently used explicit historical contexts in which they delegated authority to other speakers, and they used hardly any excerpts-in-a-series-articles on the Yugoslavia-related topics. ${ }^{23}$ Instead, the oppositional journalists more often followed more conventional journalistic practices: they authored their articles about the Yugoslav past and complemented them by interviews and statements from “authoritative” sources. In addition, by choice of these authoritative sources, the oppositional newspapers in the 1990s also gave limited access to some marginalized voices (e.g. former Yugoslav officials or independent intellectuals) providing alternative perspectives. The oppositional newspapers still mainly negatively evaluated Yugoslavia, but they focused more on problems of the communist Yugoslav system, rather than on Croatian victimization, thus also presenting the Flawed Yugoslav System Viewpoint. Another result of giving voice to sources not easily available from the mainstream newspapers was that the oppositional newspapers occasionally featured the more extreme leftist views on Yugoslavia. However, reach of the oppositional newspapers in the 1990s was limited, both by administrative and legal obstructions put into their way and by their smaller circulation numbers. Therefore, they likely influenced collective memories on Yugoslavia less than the mainstream press.

Journalistic uses of the Yugoslav past slowly started changing in the late 1990s and in the 2000s. First, even the mainstream journalists in this period, when there was less need for contextualization of the Yugoslav break-up, more often interviewed and reported on the statements of academics and protagonists, instead of inviting such persons to write articles or excerpting their texts. In addition, historical contexts in both the mainstream and the oppositional

\footnotetext{
${ }^{23}$ However, they did use such articles to contextualize the Second World War. The oppositional daily Novi list published several excerpts-in-a-series-of-articles describing the Nazi/Fascist occupation and the regional antifascist struggle. In contrast, the mainstream dailies, when describing the Second World War by excerpts-in-a-series-ofarticles focused almost exclusively on the Partisans' crimes, and sometimes on the NDH.
} 
newspapers were more often implicit as contextualization of the past was no longer the sole purpose of articles but an instrument in discussing a current debate. Such articles were often reports from stakeholders' assemblies or on newly published books.

Despite these changes, the excerpts-in-a-series articles were still an important feature of the mainstream newspapers. In the late 1990s, many were still solely authored by protagonists or academics. However, several other types of historical contexts also discussed Tito, and the mainstream newspapers in 1998 and 1998 published two interviews with two former Yugoslav officials who, for the first time, introduced the Flawed Yugoslav System Viewpoint into the mainstream press. In the 2000s, excerpts-in-a-series articles decreased even more, any many of these series of article were not excerpts anymore, but they were features based on interviews with protagonists, stakeholders or academics or reports on their work.

A difference that persisted between mainstream and oppositional newspapers in the 2000s, however, was the mainstream focus on negative evaluation of Yugoslavia and specific problems of Croatia’s position (the Croatian Ethnic Victimization Viewpoint). The oppositional newspapers, on the other hand, also discussed general problems of the Yugoslav regime (the Flawed Yugoslav System Viewpoint) and they were more likely to provide space for some marginalized voices (e.g. former Yugoslav officials). But, the mainstream and the oppositional newspapers had in common a marked increase of interest in Tito, particularly among columnists who attempted to contextualize his presence in public discourse.

Indeed, the increasing interest in Tito is probably the single most important factor that led to the commemorative articles taking up their expected dominant role in journalistic uses of the past in the 2000s in all examined newspapers but the weekly Feral Tribune, whose format was such that typically it did not report on commemorative events. Therefore, most such articles 
predominantly reported on the commemorations of Tito's birthday and death. Such reports from the field were also often accompanied with commentaries and discussions of these events and Tito. Only a couple of other Yugoslavia-related topics, beside Tito, were featured in the commemorative pieces. However, the only commemorations that truly competed with Tito's in terms of journalistic and public attention were those related to World War Two.

Other journalistic uses of the Yugoslav past in the Croatian newspapers in the 1990s and the 2000s included ironic revisits ${ }^{24}$ and historical analogues and asides (see Table 3.4). Since they were used much more rarely ${ }^{25}$ than the commemorations and the historical contexts, I will not at this place present a detailed analysis of these journalistic forms. However, the increased use of analogues and asides in the Croatian newspapers in the 2000s suggests another "normalizing" trend in this period since they were a fairly conventional journalistic form.

In addition, analogues and asides were not usually recognized as presentations of the past. Nevertheless, the analogues, for example, are potentially very powerful instruments of collective memories as they provide clear interpretive signposts that are usually seamlessly integrated in the texts on current issues. In the Croatian context, these signposts predominantly signaled that Yugoslavia should be evaluated negatively as the purpose of majority of comparisons with Yugoslavia implied a negative evaluation of people or developments evoking such memories. Yet, what potentially limits the role of the analogues is that they usually rely on readers' implied

\footnotetext{
${ }^{24}$ Ironic revisits appeared exclusively in the radical weekly Feral Tribune, mostly in the 1990s. These were satirical and re-published Yugoslav texts celebrating Yugoslavia and Tito that were written by President Tudjman, one of his ministers and a prominent nationalist journalist. Although they used the past, the sole purpose of the ironic revisits was to criticize the authors of re-published texts and to mock current political and public scene.

${ }^{25}$ With the exception of the asides on Yugoslavia or Tito that in the 1990s appeared mainly in reports from commemorations related to the Second World War (see Table 3.4).These commemorations are divided across political lines. On one side are the stakeholders emphasizing the Partisans' crimes (Bleiburg, Jazovka) and on the other side are the commemorators of the antifascist struggle or the victims of the NDH concentration camp Jasenovac. This division is reflected in evaluations implied by the asides to Yugoslavia and Tito. On one side, the asides focus on Tito as a dictator or a criminal or on Yugoslavia as a totalitarian state in which the Partisans' crimes could not be mentioned. On the other side, they focus on Tito's antifascist contributions or on the antifascist and the democratic struggle that created Yugoslavia and which is appropriated as Croatia's heritage.
} 
knowledge, without actually producing specific images or narratives on Yugoslavia that could then become parts of readers’ repertoires.

In this area, however, the role of asides might be relevant. The asides are typically noncrucial elements of articles, something that is merely a point of interest and could easily be ignored. However, by being interesting tidbits or attraction-catchers, the asides can provide images that are easily incorporated into repertoires of collective memories. In the Croatian context, most asides provided little pieces of information on Tito (e.g. Tito travelling around the world on his ship, Tito hosting Elizabeth Taylor...). These catchy facts, which were not usually available from other institutionalized sources, could thus become part of popular imagery on Tito.

The above analysis has shown that Croatian journalists' presentations of the Yugoslav past, particularly those in the mainstream newspapers, mostly reflected the "official" accounts found in textbooks, which focused on negative political and economic re-evaluations of Yugoslavia and mainly presented the Croatian Ethnic Victimization Viewpoint as the only interpretive framework of the Yugoslav. Further, in the 1990s, this uniform interpretive framework was mostly disseminated through elaborate historical contexts, often authored by "authoritative" sources, rather than by the commemorations or other more typical journalistic uses of the past.

The oppositional newspapers were slightly more conventional in their practices, and although they also featured the historical contexts, particularly in the 1990s, the oppositional journalists less often delegated the role of speakers in articles to academics, protagonists or witnesses. In addition, unlike the mainstream newspapers, which mostly hosted people close to the ruling elites of the 1990s, articles in the oppositional newspapers also sometimes gave voice to some marginalized groups not usually found in the mainstream newspapers. In this way, the 
oppositional newspapers also occasionally introduced the alternative Flawed Yugoslav System Viewpoint. However, considering the limited reach of the oppositional newspapers, it is likely that the Croatian Ethnic Victimization Viewpoint was also more central to Croatian public discourse on Yugoslavia.

The increased use of commemorative articles in the late 1990s and in the 2000s did not provide any real competition to historical contexts in diversity of perspectives on Yugoslavia as the Yugoslavia-related commemorations were focused mainly on Tito. However, it is more difficult to assess influence of the increased use of analogues and asides, since these forms mostly functioned as implicit (and possibly not recognized) frameworks for the current stories.

\subsubsection{Malleable Yugoslavia, Persisting Tito and Failed Institutionalizations}

In the period immediately after the break-up of Yugoslavia, images of the Yugoslav past underwent a drastic transformation in Croatian history textbooks and newspapers. Such malleability was, to a degree, an expected consequence of a failed communist regime - some interpretations were part of "recovery" of the past silenced in the former totalitarian regime (cf. Wertsch 2002). This includes, for example, descriptions of REPRESSIVE SYSTEM and institutionalizations of some previously denied past such as the communist Partisans' crimes at the end of World War Two. Further, some reinterpretations resulted from changed social conditions. New Croatian society strived towards capitalism and democracy. Therefore, framing Yugoslavia negatively as a NON-DEMOCRATIC and ANTI-CAPITALIST SYSTEM was consistent with the new interpretive frameworks (cf. Schwartz 1991).

However, the Yugoslav break-up also brought a failure of a multiethnic state and emergence of several new nation-states, Croatia included. In fact, the 1990s ruling Croatian elites defined themselves chiefly in national terms and embarked on a project of nation-building. In 
this context, these elites were main stakeholders of negative ethnic reinterpretations of the Yugoslav past. Therefore, while malleability of the interpretations of Yugoslavia within the frames of repressiveness, non-democracy and anti-capitalism featured elements of both posttotalitarian "recovery" of history and the meaning-based presentism in which the past is interpreted within current cultural frameworks, ethnic reinterpretations also consisted of an instrumental dimension (Olick and Robbins 1998). Indeed, the strongest ethnic frame of CROATIAN VICTIMIZATION, which univocally argued for the necessity of Croatian independence, was actively propagated in the 1990s. As seen from the earlier analyses, the ruling elites misused their access to institutional resources and imposed a Croatian Ethnic Victimization Viewpoint as the only textbook framework of Yugoslavia. Similarly, they used their journalistic alliances and likely political pressures as well, to impose this viewpoint as the main interpretive framework for newspapers. Although this framework was somewhat challenged by some oppositional newspapers and the select textbooks in the 2000s, such ethnic reinterpretations remained the central institutionalized frame of the Yugoslav past.

Negative re-evaluations of the late Yugoslav leader Tito were part and parcel of the negative re-evaluations of Yugoslavia in Croatian public discourse. However, unlike most images of Yugoslavia, the old images of Tito proved persistent. The initial reaction to the controversial character and complex historical contribution of Tito was mostly silence across both textbooks and newspapers. The textbooks' silence, which partly continued into the 2000s, can perhaps be explained by textbooks avoiding non-consensual topics, particularly in the 2000s when publishers might have feared that, in context of the increased textbook market competition, sales of controversial textbooks might be affected (cf. Schudson 1992). However, the controversy sells the newspapers. This might explain why in the late 1990s, when the media 
freedoms increased, journalists started noticing the commemorations of Tito that had been quietly renewed in Tito’s birthplace Kumrovec.

In the late 1990s, reports from Tito's commemorative events started appearing regularly in newspapers. In fact, until their appearance, Croatian journalists wrote little Yugoslavia-related commemorative articles. Indeed, none of possible competing commemorations of Yugoslaviarelated moments and people (such as commemorations of the Croatian Spring or the Archbishop Stepinac) were as successful in drawing the newspaper attention as the commemorations of Tito in the late 1990s and in the 2000, although these competing commemorations were more aligned with dominant re-evaluations of Yugoslavia. The competing Yugoslavia-related moments would occasionally prompt some anniversary journalism, but this was never so reliably and consistently covered across various newspapers as the reports from the celebrations at Kumrovec. The only comparable commemorative newspaper coverage to Tito's was that received by the commemorations related to the Second World War. ${ }^{26}$

Two points emerge in examining why the old images of Tito persisted and his commemorations were successfully institutionalized in Croatian public discourse, while the Yugoslav past was generally reinterpreted and competing Yugoslav-related commemorations failed. First, Tito’s positive images had their stakeholders or "reputational entrepreneurs” (Fine 1996). These were primarily the Association of the Antifascist Veterans and the Society of Josip Broz Tito, two organizations whose members were mainly the people who were Tito’s Partisans in World War Two and who were the generation that created the Yugoslav state. In addition,

\footnotetext{
${ }^{26}$ These were the commemorations of the Day of the Antifascist Struggle, of the Ustasha concentration camp Jasenovac, of the Partisans' execution site Bleiburg and, much less frequently, of the commemorations of Partisans' victims at the mass graveyard Jazovka. These commemorations received steady and considerable journalist attention in the 1990s and in the 2000s. Further, they also prompted a number of follow-up articles and discussions debating various evaluations of the past and their role in current public and political discourse (such as Croatian antifascist role in the Second World War, identification of the Communists with the antifascists, significance and role of the Croatian Nazi puppet-state NDH during the war, the Partisans' crimes).
} 
many of these people were active in the previous regime, and some of leaders and members were former Yugoslav officials. Although they were now a marginalized group which lost their institutional placement, as the former officials they still had some resources and organizational skills inherited from their previous lives, which increased their "mnemonic capacities" (Armstrong and Crage 2006) compared with some other marginalized groups.

Second, these groups also acted in an opportune historical moment (cf. Armstrong and Crage 2006). In the late 1990s a certain distance both from the Yugoslav break-up and the Homeland War could be established, while at the same time the country slowly started to democratize. In this context, Tito's stakeholders could more easily mobilize many of the people for whom life in Tito’s Yugoslavia was part of their living memory (cf. Schudson 1992) and who were unwilling to release images they cherished in the country in which, as a popular saying goes, "it was an honor to live with Tito".

In contrast to successful sponsorship of Tito's reputation, the problematic sponsorship may be one of reasons for the failed competing commemorations of the Croatian Spring. Stakeholders of these commemorations were former dissidents active in the 1960s/1970s movements, but this group was divided between the nationalistic protagonists and then-reformist communists. However, the nationalistic protagonists of the Croatian Spring were in power in the 1990s, whereas former reformist communists acted as their marginalized political opposition. Therefore, any commemoration of the Croatian Spring sponsored by groups in power had to be careful not to give too much credit to their political opponents, whereas such commemorations sponsored by political opposition in the 1990s lacked institutional resources.

In contrast, the World-War-Two commemorations, which were the only other successful commemorations in the post-Yugoslav period, had either the official (state) sponsorship (Day of 
the Antifascist Struggle, for example, is a state holiday) or they had strong political elites as stakeholders. For example, the commemoration of the Partisans' crimes at Bleiburg was sponsored by the right-wing politicians, including the ruling HDZ in the 1990s, while the commemoration of the NDH concentration camp Jasenovac became associated with the leading left-wing politicians, especially in the context of the opposition to rise of extreme nationalism and the neo-Ustasha groups in the 1990s. Further, the successful World-War-Two commemorations also had salient memorial sites. For example, Jasenovac has been a memorial site since the 1960s and the Austrian field of Bleiburg was a site of secret pilgrimage during the Yugoslav period.

The comparison between successful and unsuccessful commemorations suggests that one of factors contributing to persistence of Tito's reputation was the memory-work of his stakeholders who, despite their marginalized institutional position, were able to employ their resources at an opportune historical moment to renew Tito's commemorations at his birthplace Kumrovec, which was the site of Tito's celebrations in Yugoslavia. However, success of these commemorations may also be linked to some characteristics of Tito's images.

First, Tito's stakeholders could build upon the institutionalization of Tito's images in the previous regime. Tito's dates of birth and death, for example, were formally marked in the Yugoslav regime - one was a former Yugoslav holiday and the other an event commemorated by sirens for years after Tito’s death. Next, Tito’s birthplace Kumrovec was during most of the Yugoslav period a site of the annual pilgrimage. For example, during Tito's life, his birthday was celebrated by relay race that started in Kumrovec and ended in the Yugoslav capital Belgrade, with the most promising young Yugoslavians handing Tito a birthday message that was carried across whole Yugoslavia. Therefore, Tito's stakeholders could rely on cultural resonance of the 
dates of Tito’s birthday and death and the established commemorative site, similarly as the World-War-Two stakeholders could rely on their institutional resources and the established memorial sites. The failed Yugoslavia-related commemorations had no comparable institutionalized and culturally salient markers to draw upon.

Furthermore, it seems that institutionalized markers increase significance of the past events in public discourse, as they provide a prompt for a regular (e.g. annual) debate and thus they also invite regular journalistic interest. In the case of Tito’s commemorations, the successful institutionalization of annual celebrations ensured a reliable and consistent coverage of this subject across various newspapers despite this event not being officially sponsored by the state or the political elites. In contrast, the competing commemorations of the Yugoslavia-related moments and people, also non-officially sponsored, failed in institutionalization of their narratives and thus they also failed in obtaining reliable or consistent media attention. Tito, however, is guaranteed to be discussed every year following the Kumrovec commemoration. Likewise is true for the antifascist struggle, Bleiburg or Jasenovac.

All these events became more than anniversaries - they were the news to be reported. Moreover, since evaluations of the past that entered the newspaper discourse through such reports were sound bites of public speeches or statements from visitors, this also meant that the past could enter the newspaper discourse without journalists taking upon themselves an explicit interpretive role. In addition, images of Tito were well suited for newspaper coverage. For example, many news scholars noted that journalists tend to simplify and sharpen their stories by focusing on particular moments, metaphors and people (Schudson 1992; Zelizer 1992; Edy 2006). Therefore, the Yugoslav past, in its many details and complexities, was passed over for personification of Yugoslavia in charismatic and attention-drawing figure of Tito, who indeed 
personified Yugoslavia even during his lifetime.

Finally and perhaps most importantly, Tito is a truly controversial figure in Croatian public discourse. Therefore, his evaluations invite divided opinions. Indeed, representations of Tito could be seen as semiotically multivalent (Spillman 2003) or as high in cultural power in their ability to both expresses an underlying consensus and evoke various interpretations (Griswold 1987a). Tito is variously presented as a World-War-Two hero, as a World-War-Two criminal, as a progressive and benign communist leader, as a communist dictator, as a world peacemaker, as a world-class political manipulator, as a glamorous celebrity, as a president who lived in luxury while his people lived in poverty, as a beloved father of his people, and so on. Among all these various interpretations, there is an underlying agreement that Tito is somehow important and each group across whole political spectrum can find a representation that fits with their perspective (cf. Schudson 1992). This allows for co-existence of all these positive and negative evaluations and makes Tito a persistent presence from the past.

\subsection{CONCLUSION}

This chapter presents three main findings. The first finding identifies main actors in the Croatian educational system and in the media and it describes how their activities within this historical-institutional context shaped whose perspectives on the Yugoslav past were available from Croatian history textbooks and newspapers. The second finding examines journalists' role in producing collective memories. In this, I focus specifically on Croatian circumstances in the 1990s, which resulted in a more explicit use of the past than is typical for newspapers, but I also examine how normalizations of journalistic uses of the past in the 2000s contributed to production of collective memories. The final finding uses the case of Tito in newspaper discourse to examine conditions which allowed persistence of the old Tito's images and their co- 
existence with generally negative re-evaluations of all things Yugoslav. These conditions also contributed to successful institutionalization of Tito in Croatian public discourse, which other Yugoslavia-related commemorations failed to achieve.

First, I used the historical-institutional analysis of the educational and the media space in Croatia in 1991-2007 in order to explain how the main history textbook and newspaper frames on the Yugoslav past became dominated by negative political and economic re-evaluations of Yugoslavia, with a focus on repressiveness of the system and, in particular, on ethnic problems. This dominant interpretive framework particularly emphasized Croatian ethnic victimization and presented the Yugoslav break-up as national emancipation. Whereas many re-evaluations of Yugoslavia, which condemned its repressive, anti-democratic and non-capitalist elements, were part of new perspective of a post-totalitarian society transitioning towards democracy and capitalism, the overwhelming focus on national inequalities and on Croatian victimization, however, also fit strategic needs of the Croatian nation-building ruling elites in the 1990s.

In fact, actors close to these ruling elites misused their institutional placement in the Croatian centralized educational system to shape the history curriculum and history textbooks in the period immediately after the Yugoslav break-up. As a result, only the perspectives of the ruling political elite were available from history textbooks in the 1990s. Due to institutional inertia, this changed only to a limited degree in the 2000s, when Croatian society started on its path of democratizing changes following Tudjman's death in 1999 and the regime change in 2000. Although historians and expert groups increased their influence in the textbook approval system in this period, which resulted in a more liberal professional atmosphere, actual changes in the history curriculum were limited, thus placing responsibility for more critical approaches on individual textbook authors. As a result, two types of history textbooks were used in schools in 
the 2000s. One group of history textbooks continued in the 1990s tradition and presented the Yugoslav past from perspective that emphasized ethnic Croatian victimization and offered no alternative interpretations. The other group attempted a more critical approach and provided presentations of the Yugoslav past that toned down the framework of Croatian victimization and discussed general problems of the Yugoslav communist regime, including also some of its social aspects in addition to economic and political ones.

Both of these types of textbooks - and both of these types of perspectives on the Yugoslav past - were, then, potentially available to young people in schools in the 2000s. The final decision on which textbook would be used was supposedly in the hand of teachers, but various concerns have been raised regarding teachers' criteria of selection and the ways in which teachers used textbooks in classrooms. For example, Koren and Baranović note existing pressures on teachers to "conform to prevailing social and political norms; especially promoted was the notion of history teaching as the main agent for fostering national identity” (2009:107). They also mention that many teachers distrusted didactical innovations offered by some textbooks and avoided presenting multiple perspectives on controversial issues, even when such were offered by textbooks. In fact, some teachers avoided talking about controversial or sensitive issues at all (Koren and Baranović 2009).

Therefore, the analysis of Croatian history textbooks in the 2000s suggests some democratizing changes, most obviously demonstrated by existence of new textbooks which allowed the entry of minority or non-elite perspectives in the educational discourse on Yugoslavia. Nevertheless, a more democratic role of history education in producing collective memories is not necessarily a correct diagnosis. The problems outlined above indicate a situation of institutional inertia which allowed the continued use of ideological textbooks, little change in 
ways history was taught (prescriptively and with focus on chronological narrative and memorization, rather than thematically and with focus on critical thinking, as new professional developments recommend), and insufficient training of teachers in these new approaches. As a result, the current state of history education in Croatia may actually facilitate its conservative role in production of collective memories on Yugoslavia, where only one perspective, that of the 1990s ruling elites, may still reign supreme.

In addition to educational influences, the 1990s ruling elites also used political pressures within the state-controlled media space and their alliances with "suitable" journalists to disseminate their nationalist interpretation of the Yugoslav past in journalistic discourse. As a result, the interpretive framework of Croatian victimization dominated newspapers as well, particularly the mainstream newspapers. Admittedly, the oppositional newspapers occasionally featured alternative and marginalized voices (such as leftist intellectuals or former Yugoslav officials) that provided a different interpretive framework. Its main interpretive thrust was still negative, but focus was on flaws of a non-democratic, economically poorly functioning and a failed federal and multiethnic state, rather than on Croatian victimization. This perspective, however, took second place to the central role of the Croatian victimization viewpoint, particularly as reach of the oppositional newspapers was limited compared with the mainstream newspapers catering to wider audiences and less obstructed by 1990s administrative, technical and legal restraints. Therefore, in context of restrained media freedoms and political control over the major media outlets, Croatian journalists contributed to production of collective memories on Yugoslavia by pushing the perspective congruent with the ruling elites’ agenda.

Although the role of journalists in supporting particular collective memories is less systematic and structured compared with textbooks' ability to influence wide segments of 
population, they still might be influential in suggesting certain ideas about the past. This is particularly evident from specific journalistic uses of the Yugoslav past in the Croatian context in the 1990s when newspapers presented elaborate historical contexts of the Yugoslav past, whose explicit purpose was to educate public on proper re-evaluation of Yugoslavia. Such historical contexts required journalists to adopt an explicitly evaluative role which conflicted with convention of journalists as neutral commentators. However, by delegating writing of many such articles to "authoritative sources" such as academics or protagonists, journalists could still present their perspectives on the past while their editorial role in the choice of topics and authors remained hidden.

The improved media freedoms in the 2000s also, to a degree, normalized journalistic uses of the Yugoslav past, most notably by reducing importance of historical contexts and by increasing the number of commemorative articles, which, in democratic societies, are the most typical journalistic use of the past (Edy 2006). However, we should be careful not to assume that "normal" journalistic use of the past diminishes significance of journalists as producers of collective memories. For example, one other typical, though rarer or, at least, less easily recognizable, journalistic use of the past is use of analogues and asides. Indeed, their increased use in the 2000s is another "normalizing" trend. But, both the analogues and the asides can be powerful instruments in production of collective memories.

The analogues, for example, provide clearly evaluative signposts for interpretations of the current conditions based on the presumed interpretations of the past. Therefore, in use of the analogues, journalists are hardly neutral commentators. Rather, they use a certain interpretation of the past as their assumed position and implicitly suggest that reader should do the same. In this manner, therefore, journalists use the past as the model for society (Schwartz 1996b). The 
typical use of the Yugoslav past in the analogues, for example, was to condemn some current practice or individuals based on their supposed similarity to practices and individuals in the Yugoslav system. The asides, on the other hand, do not provide such interpretive signposts, and although their function in articles is usually an illustration or afterthought, these illustrations can be very effective in establishing certain images as collective memories. In the Croatian context, thus, where most Yugoslavia-related asides referred to various interesting tidbits about Tito, the asides provided images that fed the emerging consumer branding of Tito, transforming him into a figure of popular culture.

Furthermore, "normal” journalistic uses of the commemorative articles also carry implications for production of collective memories. Specifically, the conventions of commemorative journalism are such that they privilege reporting on strongly institutionalized past - the one with culturally salience or officially sponsored dates and sites of commemoration. In turn, the sheer regularity of topics discussed in such a way (their annual appearance and guaranteed coverage) means that they become the strongest elements of the newspaper production of collective memories. However, the necessity of strong institutionalized markers to prompt reliable newspaper coverage also means that newspapers will likely reproduce perspectives of those groups that are most successful in institutionalizing them. Most often, this will be political elites, although they need not be, as the case of Tito demonstrates.

However, the commemorations of Tito also had a particularly strong institutional heritage of the previous regime and a highly commemorable subject (Tito was a charismatic and attention-drawing figure who could be diversely interpreted) as factors working on their behalf. Therefore, non-elite stakeholders sponsoring that event were able to compete with political elites by mobilizing their "mnemonic capacities" at an opportune historical moment (Armstrong and 
Crage 2006), which allowed them to successfully institutionalize their marginalized perspective on Yugoslavia, and make it a part of the newspaper production of collective memories. Indeed, these developments illustrate well how certain images of the past persist, while others fail. Both persistence of the old images of Tito in light of all other reinterpretations of Yugoslavia and his successful institutionalization in newspaper discourse can be traced to interaction of three factors that were absent in failed institutionalizations: the well-timed activities of Tito's stakeholders, dramatic and plural character of Tito's interpretations and cultural salience of previous institutionalizations of Tito.

In conclusion, the above analysis also suggests some general lessons for role of history education and journalistic uses of the past for production of collective memories. Primarily, both history education and journalistic uses of the past have a strong potential to privilege perspectives of political elites or of groups who have skills, resources and a favorable environment to use these "high mnemonic capacities" (Armstrong and Crage 2006) to gain access into the educational discourse or the mainstream media. In authoritarian contexts, the dominant role of the ruling political elites is a given - they can abuse their power to control both history education and the mainstream media and impose their narrative of the past through these channels. However, in democratic contexts, political elites also have a better starting position as much of their influence is dependent on the state organization and routines privileging "official channels”. Specifically, in societies with centralized educational system, such as Croatia, the introduction of alternative or minority perspectives into the educational discourse will be more difficult as the natural state is one of institutional inertia in which expert groups and stakeholders of alternative viewpoints must put extra effort in engaging their resources to institutionalize their perspectives in history textbooks. 
Likewise, the most conventional journalistic uses of the past also privilege official sources and the highly institutionalized markers of the past (e.g. sites and dates which provide regular prompt to commemorations), which means that non-elite groups will receive a treatment comparable to the officially-sponsored commemorations only if they are able to organize successful commerative event. In the Croatian case, sponsors of Tito's reputation were thus able to receive considerable public and media attention by drawing on heritage of Tito's institutionalization from the previous regime and on commemorability of Tito's images in an opportune historical moment. But, such an access to resources for institutionalization of their perspectives will likely be easier for the groups with official channels at their disposal so they will also more likely have a greater role in producing collective memories.

However, production of collective memories is only the first step in their establishment as the societally dominant memories. What matters as well is how these memories are used by their mediators and by their audiences. These are some of issues I will address in the following chapters which examine how institutionalized memories on the Yugoslav past were received by particular segments of young Croats and how these young people negotiated various images of Yugoslavia that were available to them. 


\section{Chapter 4: Reception of Collective Memories and Interpretive Communities of Yugoslav Past among Two Croatian Generations}

\subsection{INTRODUCTION: INDIVIDUAL APPROACH TO COLLECTIVE MEMORIES}

The previous two chapters adopted structural approach by examining how collective memories on Yugoslavia were produced in history education and journalistic discourse. These chapters have shown that the main textbook and newspaper frames were dominated by negative political and economic re-evaluations of the Yugoslav past, and that they emphasized repressiveness of the former regime and, in particular, Croatian ethnic victimization. Such dominant frames resulted from a particular historical-institutional context of post-Yugoslav Croatia. This included recovery of perspectives silenced in Yugoslav totalitarian regime and reinterpretations of the past from perspective of a newly democratic and capitalistic regime. Moreover, such dominant frames, and in particular the overwhelming focus on Croatian ethnic victimization, that pervaded 1990s history textbooks and mainstream newspapers, were also work of actors close to the 1990s nation-building ruling elites, who used their institutional access and resources of an authoritarian state to impose their uniform interpretive framework of Yugoslavia on Croatian educational and journalistic discourse. Space for oppositional or alternative viewpoints was restricted. Therefore, with an exception of re-emergence of Tito in the newspaper discourse in the late 1990s and in the 2000s, alternative perspectives, discussing social aspects of the Yugoslav regime or presenting its general flaws rather than emphasizing Croatian victimization, occupied a marginal position in institutionalized memories of Yugoslavia.

In the present and the next chapter, I complement the structural approach by examining how these institutionalized frames were received by young Croats. Several authors cautioned against identifying collective memories with only institutionalized memories or over-focusing on 
production of representations of the past. Rather, these authors suggested incorporating individuals in the study of collective memories and complementing the study of production of collective memories with the study of their reception or consumption (Irwin-Zarecka 1994; Confino 1997; Crane 1997; Kansteiner 2002; Wertsch 2002; Schwartz and Schuman 2005; Beim 2007). In this individual approach to collective memories, focus of the analysis shifts away from mnemonic struggles over institutionalization of memories that are fought in public arena among various stakeholders, from political elites to local communities. Instead, the individual approach to collective memories focuses on non-institutionalized memories: individual beliefs about the past. If brought into public arena, such memories may both support or challenge the memories produced from above (Bodnar 1992). But, such memories may also never be brought into public arena, as, for instance, happens in totalitarian or authoritarian regimes. They may exist at level of oral history, surviving through generational word of mouth or dying out eventually, when generational transmission of stories trickles out and no institutionalized mnemonic devices provide support.

Analytic division between structural and individual approaches reflects two different conceptualizations of collective memories - the so-called collectivistic and individualistic conceptualizations (Olick 1999). Whereas collectivistic conceptualizations center on embodied or institutionalized memories that exist independently from individual minds (see, for example, Assmann 1995; Nora 1996a), individualistic conceptualizations highlight individuals as carriers of memories (Halbwachs 1992 [1952]; Olick 1999). In these conceptualizations, it is individuals who actualize potential collective memories in their minds. Presentations of the past receive their “use-value” only by individuals attributing meaning to them (Kansteiner 2002). Therefore, this dimension emphasizes the role of reception and recipients as active meaning-makers who 
interact with available cultural material, including the available institutionalized memories (Griswold 1994).

Both of these approaches - and both of these conceptualizations - are equally valid, each focusing on one dimension of collective memories and complementing each other. Indeed, Schwartz and Schuman (2005) situate collective memories at intersections of institutionalized memories (“new structural memory”) and individual beliefs. However, a strength that the individual approach brings to the study of collective memories lies in examining interpretive work of recipients of institutionalized memories and in exploring patterns of different responses of various audiences. In particular, the individual approach can examine how individuals at different social and cultural locations form multiple “interpretive communities” of memories, whose different specific experiences and concerns - or different “cognitive orientations” - lead to their different perspectives and interpretations of the past (Radway 1984; Griswold 1994; Zerubavel 1997; Zelizer 2008).

Nevertheless, surprisingly few empirical studies pursuing the individual dimension are published in mainstream English-speaking literature on collective memories. This is a curious situation because "vernacular” communities of memory (Bodnar 1992) and (explicit or implicit) challenges to “official” memories (Wertsch 2002) are an expected, rather than a deviant state. Even in totalitarian regimes, the "kitchen talk" may perpetuate oppositional views of the past and the present (Wertsch 2002). In fact, scholars of collective memories well recognize this fact, and many papers presented at various conferences of collective memories examine the individual dimension of remembering. ${ }^{27}$ Still, the published empirical work incorporating individual beliefs about the past is rare (for exceptions, see Schwartz and Schuman 2005; Schuman et al. 2005, and

\footnotetext{
27 Consider, for example, the papers presented at "Forms and Functions of Social Memories" conference at the University of Erlangen in 2010 (http://www.soziale-erinnerung.de/english/index.html).
} 
survey studies on the generational differences in the recall and knowledge of polical events, most often conducted by Schuman and his colleagues).

In addition, there is also the research output of the oral history field. However, although the oral history work on individual memories is certainly not scarce, this area mainly remained outside the mainstream study of collective memories because the oral history studies typically privilege individuals and their life stories to such a degree that wider social frameworks - which are key for any sociological approach to collective memories - almost completely disappear from such analyses (Olick 1999; Hamilton and Shopes 2008). Therefore, despite the theoretical awareness of the reception problem and the cautions against conflating institutionalized memories with individual beliefs, the collective memories field still needs a deeper examination of individual remembering situated in a wider social context of institutionalized memories and various groups' social and cultural locations.

Addressing this dimension is one of goals of this and the next chapter. Specifically, in the present chapter I examine individual memories of the Yugoslav past among two Croatian postYugoslav generations by focusing on two aspects of their reception of memories institutionalized in Croatian history textbooks and newspapers. First, I analyze the dominant frames of Yugoslavia among these young people and I examine how their individual frames compare to the dominant institutionalized frames of Yugoslavia. This analysis identifies the main differences and similarities between institutionalized and (aggregate) individual frames on Yugoslavia among a particular segment of the Croatian population, which, due to its youth, was most dependent on secondary sources for their images of Yugoslavia. This also allows me to evaluate a relative success or failure of such institutionalized memories on new generations.

Second, the analysis of the present chapter also examines group variations in individual 
frames of Yugoslavia, in particular, the generational, educational, class and regional patterns in reception and interpretations of the Yugoslav past. By examining these issues, the present chapter specifies Griswold’s (1994) “cultural object-reception-social world” nexus in the formation of collective memories: it defines "audiences" or receivers of institutionalized memories (cultural object) as active meaning-makers and it examines their social and cultural locations as factors influencing their interpretations of the Yugoslav past.

\subsection{RECEPTION OF COLLECTIVE MEMORIES AND INTEPRETIVE COMMUNITIES}

\subsubsection{Generations as Interpretive Communities of Memory}

Many authors in the reception studies examined differences in interpretations between various interpretive communities. Their findings highlight that particular experiences and concerns stemming from individuals' socio-cultural locations are the main factors influencing interpretations of a cultural object. Various groups "read" various cultural objects in terms that are most relevant to their own experiences, be that concerns of the nation-building, racial relations (Griswold 1987a), issues of tradition and family (Liebes and Katz 1993), or personal ethnic identifications (Shively 1992). Indeed, such a finding is well within the cognitive sociology's expectations about the social organization of attention, which suggest that individuals' salient social and cultural locations filter what they determine as (ir)relevant and how they interpret things at their mental horizons (Zerubavel 1997). Furthermore, in the field of collective memories, Irwin-Zarecka (1994) argues that if people cannot make a relevant connection between memories produced from above and their own salient experiences, these memories will necessarily fail in their reception.

However, individuals are characterized by more than one socio-cultural characteristic shaping their experiences and expectations, and different aspects of their multiple identifications 
may be variously salient in different contexts (Stryker and Burke 2000; Stets and Burke 2000; Armstrong and Weinberg 2006). It is necessary, therefore, to establish which social categories might be most salient for individual remembering. Following Mannheim and the work inspired by his thesis on the generational consciousness, generational experiences emerge as one such relevant category filtering remembering and interpretations of institutionalized memories.

Mannheim (1952) sees generations as relevant social categories of experiences. Generations are defined not only by individuals belonging to the same age cohort, but also by individuals who share historical, geographical and social positions. These shared positions expose individuals to the same social experiences at similar stages in their lives, so that they create a distinct generational culture or consciousness (Mannheim 1952; Pilcher 1994). The period of "the first impressions" (the period of formative or critical years) is crucial in this process since the first impressions become imprinted on individuals' later experiences (Mannheim 1952). In fact, much of the social psychological work in memory focused on importance of formative or critical years of adolescence and early adulthood (Conway 1997). This work established that individuals remember best, both in terms of autobiographical moments and larger political and societal events, what they experienced at the formative stage of their life-course.

This finding has been further confirmed by research on recall and knowledge of political events. These studies identified which historical events respondents spontaneously remembered as important and they also examined respondents' knowledge of particular events (Schuman and Scott 1989; Schuman and Rieger 1992; Lang et al. 1993; Scott and Zac 1993; Schuman et al. 1994; Jennings 1996; Schuman, Belli, and Bischoping 1997; Schuman et al. 1998; Schuman and Corning 2000; Schuman, Vinitzky-Seroussi, and Vinokur 2003; Schuman and Rodgers 2004; 
Schuman and Corning 2006; Larson and Lizardo 2007). Such studies concluded that events experienced in critical or formative years of adolescence and early adulthood are the most impressionable. The result is generational pattern of collective memories: the events from one's formative years are the most easily recalled and most often deemed important (Schuman and Scott 1989; Scott and Zac 1993; Schuman and Rodgers 2004). Further, individuals are most knowledgeable about the events of their formative years (Jennings 1996; Schuman et al. 1997). These are also the events that individuals most often recount in terms of their personal experiences, rather than in more abstract terms that later generations would use in describing the same events (Schuman and Scott 1989; Scott and Zac 1993).

Nevertheless, generational imprinting of the past might also be affected by the characteristics of remembered events (cultural objects). Some types of events may extend the cohort effect to the period preceding or following the formative years of adolescence and early twenties (Schuman and Corning 2000, 2006). Specifically, the events that are simple and dramatic (e.g. the fall of the Berlin Wall) can be impressionable even in early childhood (Schuman and Corning 2000). The more abstract events, which require more subtle or complex understandings (e.g. the Cuban Missile Crisis) are also imprinted in the late twenties or early thirties (Schuman et al. 1998; Schuman and Corning 2000). Finally, some events that were tremendous at the moment of happening (cf. Pennebaker and Banasik 1997) become part of repertoire of political knowledge of all people alive at that moment (Lang et al. 1993; Schuman et al. 1994; Schuman et al. 1997; Schuman and Corning 2000, 2006).

Further, not all members of a generation are equal in their socio-cultural locations. Therefore, not all events experienced in their impressionable years will be equally memorable nor they will be equally interpreted by all members of a generation. Mannheim (1952) accounted 
for such fragmentation of generational experiences by introducing the concept of a generation unit. The generation unit refers to those segments of a generation that, in addition to shared generational and socio-historical location, also shared similar responses or interpretations of the same events due to their more specific common experiences (class experiences, for example). Therefore, we could say that Mannheim defines generation units as interpretive communities within generations. Their existence is well documented in research on recall and knowledge of political events. Some factors that this research found to be fragmenting generational experiences were race and ethnicity, regional background, gender and party identity.

For example, Griffin (2004) replicated Schuman and Scott’s research (1989) on the generational recall of political events and demonstrated importance of race and region. In Griffin's study, memory of the Civil Rights Movement was more salient for the Black respondents than for the White respondents. Exceptions were the Whites in the South who were, similar to the African-Americans all over the USA, affected by this movement in their formative years. Likewise, in replication of research by Schuman et al. (1994) in Lithuania, ethnicity emerged as a factor stratifying generational experience. The Lithuanian and Russian members of the same generation interpreted different events as significant. In some other examples from the research on political knowledge, gender filtered generational perception as men were more likely to know more about military events from their formative period than women (Schuman et al. 1997; Schuman et al. 2003). Also, the party identity and the regional background affected which analogy with the past proved more salient for particular sections of a generation (Schuman and Corning 2006).

Therefore, experiences shaping individuals' interpretive frameworks are shaped by various aspects of their socio-cultural locations. The generational effect, in particular, might be relevant 
as it exposes individuals to similar experiences at similar stages of their lives (Mannheim 1952). However, depending on the characteristics of events, the generational effect might be extended to include some dramatic events that are be remembered by all people alive at that moment, even small children (Schuman and Corning 2000).

In light of this, I propose that the examined young Croatian generations, who both spent their formative years in the post-Yugoslav period, will be influenced by dominant negative political, economic and ethnic re-evaluations of this period. However, while this negative discourse on Yugoslavia might be more unproblematic for post-communist generation, who had no experience of life in Yugoslavia, transitional generation might have experienced an extended cohort effect (Schuman and Corning 2006) and they may expose tensions between two different evaluative frameworks, one colored by romanticized memories of their early childhood and one critically influenced by negative re-evaluations of their formative years.

However, various social-cultural characteristics might also interact with the generational effect to filter what is remembered and how. Whether the generational effect will be mediated by some social experiences depends primarily on the link individuals are able to establish between their specific experiences and the remembered past (Irwin-Zarecka 1994). For example, in case of Yugoslavia, which broke up amidst the war among various ethnic groups, it is likely that ethnicity or regional background will be more salient categories of experience than, for example, gender. Among the examined Croatian generations, in particular, regional background might fragment generational experiences as young people coming from regions that were more directly or more adversely affected by the war might be more receptive to negative re-evaluations of Yugoslavia. In addition, class experiences might also be important and young people coming from working-class backgrounds might be more sensitive to social perspective on Yugoslavia, 
even though it was missing from dominant institutionalized accounts.

\subsubsection{Education and Remembering the Mediated Past}

However, in addition to generational experiences fragmented by various socio-cultural characteristics, recall and interpretation of the past events and people might also be affected by education. In fact, when it comes to remembering the past which was not personally experienced, education might function not only by fragmenting generational experiences, but it may also be significant across generations as it provides individuals from various generations with similar historical information and explanations of the past.

Education influences individual beliefs on the past at two different levels (Schuman and Corning 2000). The first is level of political socialization, where education exposes individuals to institutionalized presentations of the past. As elaborated in Chapter Two and Three, the formal education is a powerful instrument of institutionalization of memory and its reach - both through the history curriculum taught in schools and through the officially approved history textbooks (Apple 2000, 2003) - is not easily paralleled by other, less structured and less authoritative sources of collective memories. In fact, belief in the overwhelming influence of education on young people is a motivation for many of the textbook battles fought in numerous societies (see, for example, Podeh 2000; Koren and Baranović 2009; Dierkes 2010).

Thus, in his research on presentations of World War Two among the Soviet-educated and the post-Soviet generations, Wertsch (2002) demonstrated an effect of ideological socialization. The younger Soviet-educated respondents in their late twenties were much more similar to the older Soviet-educated respondents in their fifties than to the young people in their early twenties or late teens educated in the post-Soviet system. In this case, therefore, a different exposure to educational presentations of the past trumped the generational similarities between the Soviets in 
their late twenties and those in their early twenties. Similarly, research on recall and knowledge of political events has also shown that education often diminishes generational effect. For example, respondents evaluated as significant even those events they did not experience during their formative years because they learned about their relevance in school (Schuman and Corning 2000; Schuman et al. 2003; Larson and Lizardo 2007). Therefore, individuals of different generational experiences might share some interpretations of the past obtained in school.

At the same time, education may also provide “cognitive sophistication” which gives better-educated individuals critical skills to question what they are taught, more subtle understandings of the complex past developments and resources to find alternative information (Schuman and Corning 2000). Therefore, this may allow the better-educated individuals to evaluate and interpret various cultural objects, including presentations of the past, differently from the less-well educated individuals. As a result, different levels of "cognitive sophistication" might lead to educational fragmentation within generations.

For example, in Shively’s study (1992) of interpretations of the Westerns, the bettereducated Native Americans were more critical towards stereotypical representations of the Native Americans in these movies, whereas the Native Americans from the reservation, who had no college education, did not see stereotypical portrayal as an issue. In addition, research on recall and knowledge of political events has shown that when the understanding of historical events required greater historical perspective, which is usually provided by education, these events (e.g. end of Communism) were remembered better by the better-educated respondents (2004). In contrast, experiences of formative years carried greater weight, independent of education, in case of dramatic events (e.g. Kennedy assassination) (2004).

Therefore, in influencing knowledge and beliefs about the past, education might interact 
with generational experiences in complex ways. On the one hand, education may lead to fragmentation within each generation, as better-educated young Croats within each generation might be more "cognitively sophisticated" and thus more critical towards institutionalized presentations of the past. On the other hand, education may either sharpen differences between two generations, if the early experiences of the Yugoslav educational system turn out relevant for the transitional generation, or, just the opposite, education may diminish the generational differences as both generations were exposed to dominant negative re-evaluations of Yugoslavia in their formative years.

In the present chapter, therefore, I examine how successful were presentations of the Yugoslav past institutionalized in Croatian history textbooks and newspapers among young Croats. I also explore similarities and differences in reception of institutionalized memories between two young generations, one with early childhood experiences and the other with no experience of Yugoslavia. These generational groups were further examined for regional and class differences in their portrayals of the Yugoslav past. Finally, I also examine how education affected interpretive frameworks of these two generations and whether the educational effect trumped the generational effect. Therefore, the present chapter addresses the following questions:

1) What were the main frames of Yugoslavia among young Croats? Were there any differences between the textbook and newspaper frames of Yugoslavia and those expressed by young Croats?

2) What were the group differences in individual (aggregate) frames of Yugoslavia? In particular, how did education interact with the generational experiences? 


\subsection{METHODS}

The present chapter examines individual frames of communist Yugoslavia among Croatian transitional (born 1978-81) and post-communist generation (born 1989-91). I conducted 72 indepth interviews with these two generations between October 2008 and November 2009, when post-communist individuals were 18-20 years old and transitional individuals were 27-31 years old. Interviews solicited data on individuals’ early childhood in Yugoslavia (for the transitional generation), impressions of life in Yugoslavia that came from other sources (e.g. family, school, the media) and their evaluations of various aspects of life in Yugoslavia (interview guide is available from Appendix E).

Respondents were sampled through the maximum variation sampling (Lindlof and Taylor 2002) with the goal of collecting as various narratives on Yugoslavia as possible. The respondents were recruited based on three characteristics: generation (based on the year of birth), education (vocational high school vs. college or college-track high school) and regional background (three regions differently affected by the Homeland War). The complete sample consisted of 72 individuals, where each cell, defined by generation, education and regional background, consisted of six individuals (see Table 4.1 and Appendix D for the list of respondents).

Table 4.1: Sample of Interview Respondents

\begin{tabular}{|c|c|c|c|}
\hline \multirow{2}{*}{\multicolumn{2}{|c|}{$\begin{array}{l}\text { Transitional generation / Post-communist generation } \\
(\mathrm{N}=72)\end{array}$}} & \multicolumn{2}{|c|}{ Education: } \\
\hline & & College & Vocational/No college \\
\hline \multirow{3}{*}{$\begin{array}{c}\text { Region } \\
\text { (of most childhood } \\
\text { and adolescence): }\end{array}$} & $\sim$ NW Croatia, Northern Coast ${ }^{i}$ & $6 / 6$ & $6 / 6$ \\
\hline & $\sim E$ and parts of Central Croatia ${ }^{i i}$ & $6 / 6$ & $6 / 6$ \\
\hline & S Croatia, Lika ${ }^{\text {iii }}$ & $6 / 6$ & $6 / 6$ \\
\hline
\end{tabular}

${ }^{\mathrm{i}}$ Respondents coming from following counties/areas least affected by war (N): Zagreb area (14), Krapinsko-zagorska (5), Varaždinska (1), Bjelovar area (3), Rijeka area (2)

${ }^{\mathrm{i}}$ Respondents coming from following counties/areas on the frontlines (N): Sisačko-moslavačka (2), Virovitičko-podravska (3), Požeškoslavonska (1), Brodsko-posavska (7), Osječko-baranjska (1), Vukovarsko-srijemska (9)

${ }^{\text {iii }}$ Respondents coming from following counties/areas experiencing air bombing and/or some direct fighting (N): Lika (4), Zadarska (5), Šibenskokninska (6), Splitsko-dalmatinska (3), Dubrovačko-neretvanska (5) 
In addition, respondents were asked about their parents’ occupations. I used information on the occupation of the higher-class parent to classify the respondents as salariat, intermediate class or working class according to the three-class European Socio-Economic Classification (ESeC)(Rose and Harrison 2007). ${ }^{28}$ The link between class and education that is suggested by various social stratification studies was evident from my research as well. While the overlaps between class and education showed both some upward and downward mobility among respondents, the better-educated respondents were still concentrated among individuals from salariat, and the respondents with the vocational education were concentrated among people with working-class backgrounds (see Table 4.2).

Table 4.2: Educational and Class Backgrounds of Interview Respondents ( $N=72)$

\begin{tabular}{|c|c|c|c|}
\hline & \multicolumn{2}{|c|}{ Education } \\
\hline & & College $(\mathrm{N}=36)$ & Vocational/No college $(\mathrm{N}=36)$ \\
\hline \multirow{3}{*}{$\begin{array}{c}\text { Class } \\
\text { Background }\end{array}$} & Salariat $(\mathrm{N}=27)$ & 19 & 9 \\
\hline & Intermediate Class $(\mathrm{N}=21)$ & 10 & 11 \\
\hline & Working Class $(\mathrm{N}=24)$ & 7 & 17 \\
\hline
\end{tabular}

In the present chapter I first examined reception of institutionalized memories on Yugoslavia. Therefore, I compared available (aggregate) individual frames with textbook and newspaper frames presented in previous two chapters. For this reason, in coding the interviews, I used the textbook and newspaper coding strategy described in Chapter Two. The units of analysis were thematic codes, or specific utterances about Yugoslavia within interviews. Each interview was coded line-by-line for thematic codes. The codes were then attached to appropriate hierarchical framing groups of "meta-frame (the overarching interpretive package) - frame (the central organizing idea) - frame attribute (a concrete expression of the central organizing idea indicating certain evaluation of Yugoslavia) - idea element (the specific idea about

\footnotetext{
${ }^{28}$ Salariat consists of professionals, administrative and managerial occupations and higher grade technician and supervisory occupations. Intermediate class consists of higher grade white collar workers, small employer and selfemployed occupations including small farmers and lower grade technician and supervisory occupations. Working class consists of lower services, sales and clerical occupations, lower technical occupations and routine occupations.
} 
Yugoslavia)”.

In the analysis of intersections between institutionalized and individual frames I focused on noting presence and absence of textbook and newspaper frames in individual accounts of the Yugoslav past and on identifying any new interview frames. Based on the examination of typical appearances of idea elements in interviews, I considered the frame prevalent if a least one of its idea elements appeared in more than 20 interviews, which was a little less than a third of the sample (appearance of an idea element in more than 30 interviews occurred in only several cases). I considered the frame rare if none of its idea elements appeared in at least five interviews. All frames in between were considered available.

In the second section of the analysis, I focused on interpretive communities of memory and, therefore, I examined the generational, educational, class and regional differences in distribution of various frames among the respondents.

\subsection{INDIVIDUAL FRAMES OF THE COMMUNIST YUGOSLAVIA}

\subsubsection{Main Frames of Yugoslavia among two Croatian post-Yugoslav Generations}

Negative political, economic and ethnic frames that dominated institutionalized memories of the post-Yugoslav period were in some form available among most young Croats. However, these frames were less easily available than the frames describing Yugoslavia’s perceived positive social characteristics. Furthermore, when young Croats talked about negative political and economic aspects of Yugoslavia and about its repressiveness and ethnic victimizations of the Croats, these descriptions were often more simplified and vaguer than the textbook and newspaper descriptions. The respondents usually used only few idea elements describing particular frames, thus considerably reducing detailed accounts available from textbooks and newspapers on political, economic and ethnic problems of Yugoslavia. In fact, comparing these 
simplified negative re-evaluations of Yugoslavia to much more pervasive accounts of Yugoslavia's better social aspects suggests that the success of institutionalized memories on Yugoslavia among two Croatian post-Yugoslav generations was limited.

Indeed, the overwhelming focus that the young Croats of both generations put on social characteristics of Yugoslavia - which was a perspective completely absent from history textbooks and which appeared in ž newspapers only in the late 1990s and in the 2000s - makes such descriptions hearable silences (Linde 2009) or noticed absences (Irwin-Zarecka 1994) in institutionalized memory on the communist Yugoslavia. Further, almost every single respondent in the sample used some social perspectives on Yugoslavia, such as descriptions of good or better lives, which was unparalleled in any other description of Yugoslavia. In fact, the only images that came even close to this were descriptions of the tremendous impact of Tito's death and references to Tito's cult of personality. Therefore, these stories should be characterized as what Linde (2009) calls "core institutional memory" - these are stories of the past that everyone knows or is expected to know, and which, therefore, re-appear in various versions of the past. The fact that the core individual memories on Yugoslavia were absent from institutionalized presentations of the past is a telling indicator of different concerns of "lay people" and of those who shaped the textbook and newspaper frames.

Other minor textbook and newspaper frames were minor in the interviews as well, and I will not present them in detail. Suffice only to say that these minor frames were also much more simplified in individual accounts than they were in textbooks and newspapers. For example, INTERNATIONAL POLITICAL INDEPENDENCE was mostly represented only by the claim that Yugoslavia's international presence was strong, and the MODERNIZATION frames, if used at all, mostly mentioned industrialization or the improved conditions after the initially difficult 
post-World-War-Two times. CULTURAL DEVELOPMENTS, ANTI-COMMUNIST

RESISTANCE or CROATIAN CATHOLICISM ${ }^{29}$ were hardly mentioned at all. Therefore, in the rest of this section, I present a more detailed analysis of the main negative institutionalized frames available from individual accounts of the Yugoslav past and I describe the hearable silences on social aspects of Yugoslavia and Tito.

\subsubsection{Presence of Dominant Institutionalized Frames in Individual Frames of Yugoslavia NON-DEMOCRATIC AND ANTI-CAPITALIST SYSTEM}

The descriptions of Yugoslavia as NON-DEMOCRATIC and ANTI-CAPITALIST

SYSTEM were two most consistent negative meta-frames of Yugoslavia in history textbooks. In newspapers, they were more often taken-for-granted and therefore rarer, but they were still fairly available. Individual accounts follow a similar pattern of negative re-evaluations of Yugoslavia due to its non-democratic and anti-capitalist nature. Almost half of respondents described the ideological aspects of Yugoslavia and about a third mentioned various limitations of freedoms and rights. In addition, around a dozen respondents condemned Yugoslavia for its one-party rule. Frederica and Lili illustrate such negative evaluations well.

...there is that propaganda, political, from within...what I said just now about Tito, he is, like, president for life and there is no freedom there, no free elections... and that indoctrination from the very beginning..in schools, uhm, this communism, this is to me totally like "1984". (Frederica, female, transitional generation, college)

...it's not right that people, that people have no right to vote, it's not right that one party is a ruler, uhm, dictator and, one party is not-, there are no elections there, this isn't right. (Lili, female, post-communist generation, college)

With exception of the 1980s consumerist scarcity personally experienced by the transitional generation, the anti-capitalist descriptions of Yugoslavia were less prevalent, though still available. Most often, this included defining Yugoslavia as a system with no private property

\footnotetext{
${ }^{29}$ Exception is a general agreement that Catholicism is important for the Croatian identity.
} 
or with state ownership, mentioning the 1980s economic crisis or describing Yugoslavia as an inefficient or bureaucratic system in which managers were chosen by political criteria. In the illustrations below, Blizanka thus condemns limitations on private ownership and Picard brings up problems of the socialist system.

For me, this is a bad thing...you can't have private property, that is, you could have it, but then you lost some other privileges. So, they liked most the people who were, uhm, tied to them...social apartments...and land, everything was social, everything belonged to some community. Personally, I don't like it.

(Blizanka, female, transitional generation, vocational)

... it was a system that was absolutely unsustainable because, I don't know, uhm-. The bad things were listlessness, bureaucratization, which, again, were linked to the Party.

(Picard, male, transitional generation, college)

Further, whereas the respondents usually did not mention democratizing changes within Yugoslavia, some described the Yugoslav system as an atypical socialism with some capitalist elements. In addition, more than dozen respondents questioned implicit superiority of capitalism over socialism by claiming that Yugoslav economy functioned better than Croatian, and two respondents explicitly claimed that socialism was preferable to capitalism.

\section{REPRESSIVENESS AND THE ETHNIC PERSPECTIVE ON YUGOSLAVIA}

In textbooks and newspapers, descriptions of REPRESSIVENESS and CROATIAN VICTIMIZATION were the most prevalent negative re-evaluations of Yugoslavia. These negative frames were fairly available from young Croats as well. In describing REPRESSIVENESS, about a third of respondents gave examples presenting Yugoslavia as a police regime which, for instance, sent people to jail because they joked about Tito or criticized the Government. As frequently, young Croats mentioned anti-religious repression. Other, less prevalent repressive descriptions usually referred to supposedly voluntary Yugoslav work actions as forced and exploitative work for the state. The respondents also mentioned persecutions of 
opponents and critics, as well as retributions after World War Two and after suppression of the 1960s/1970s movements. The quotes below illustrate some of the fear and persecutions characterizing the Yugoslav repressive state.

...I think that people really felt repression and that, uhm, everybody looked behind their backs and were afraid that, God forbid, they'd say something somewhere where it shouldn't be heard. (Maris, female, transitional generation, college)

...I think it was bad that, uhm, people were not free, uhm, because...you couldn't say what you wanted, but, uhm, you say Tito is bad... and that's it, jailed.

(Tihomir, male, post-communist generation, college)

...in Slavonia [eastern Croatian region] people sometimes talk how...teachers...ripped off the cross pendants from children's necks.

(Marija, female, transitional, college)

However, not everybody used the dominant negative frame of REPRESSIVENESS. For example, about a dozen respondents questioned the prevalent stories of religious repression by claiming this was not part of their or their family experience. A similar number of respondents also compared freedoms and condition in Yugoslavia favorably to other communist countries. One respondent described Yugoslavia as a more humane socialism, and one respondent repeated parental testimony of personal freedoms in Yugoslavia. In addition, two accounts proposed a possibility that the degree of persecutions in Yugoslavia was exaggerated today.

The descriptions of CROATIAN VICTIMIZATION included few such relativizing accounts. Only two respondents questioned if Croatia was as exploited in Yugoslavia as it was typically claimed, and five respondents thought that Croatia had a powerful political position. Instead, the claims that Croatia was indeed exploited, both economically and politically, by the Serbs in Yugoslavia, were among the most prevalent negative re-evaluations of Yugoslavia, expressed by about half the sample. However, the newspaper and particularly the textbook descriptions of Croatian victimization were usually detailed accounts touching upon its many 
different aspects. The interview accounts, in contrast, focused mostly on the idea of exploitation, which was frequently also accompanied with the claims that the former regime suppressed the Croatian identity and national expression. The quotes below illustrate both of these claims.

...Croatia was a cash cow. You know, a goose with golden eggs for the whole Yugoslavia. (Djuro, male, transitional generation, college)

Croatia...was in that Yugoslavia as a pack animal, it carried the burden for everybody, it carried the economic burden for the whole state and got the least profit out of it, everything from that went to Belgrade [Serbian and Yugoslav capital].

(Joshua, male, post-communist generation, college)

We are Croats, but only now we got...this identity that we can freely express, and in those times, as we all know very well, don't we, you couldn't express that.

(Zoran, male, transitional generation, vocational)

[Yugoslavia] as something that smothered our, I don't know, our ...nationality, something that smothered us as Croats.

(Ela, female, post-communist generation, college)

Other ethnic frames, but CROATIAN VICTIMIZATION, were less available from young Croats. When mentioned, these ethnic frames usually took a few specific forms. For example, the only prevalent idea element (mentioned by a third of respondents) in this group of ethnic frames identified FALSE FEDERAL ORGANIZATION almost solely by centralization in the Yugoslav and Serbian capital Belgrade. Nine respondents, mostly of the transitional generation, however, relativized centralized character of Yugoslavia by comparing this situation to the current central role of the Croatian capital Zagreb.

Similarly, the NATIONAL INEQUALITY frame was represented by two main ideas. The first one, expressed by less than a dozen respondents, identified Croatia as one of the most developed republics in Yugoslavia which was thwarted by unequal regional re-distribution of finances. About the same number of respondents, however, believed that Croatia's economy was in better state than in other republics. The second, unopposed and only slightly more frequent 
expression of the NATIONAL INEQUEALITY frame pushed the focus on Serbs and accused them of political and economic dominance and of privileged position in Yugoslavia.

Finally, the least frequent frame, describing how YUGOSLAV UNITY VIOLATED NATIONAL RIGHTS, was usually featured only by several references to a general suppression of the national rights in Yugoslavia, by evaluations of Yugoslavia as an artificial entity and by a few mentions of Yugoslav ethnic tensions. However, relativizations of the last statement were slightly more frequent than its affirmations, with about a dozen respondents claiming ethnic differences were not felt in Yugoslavia or that there are more ethnic tensions today.

\subsubsection{Hearable Silences in Institutionalized Memories of Yugoslavia SOCIAL PERSPECTIVES ON YUGOSLAVIA}

The dominant individual frames of communist Yugoslavia differed considerably from the main textbook and newspaper descriptions of the Yugoslav past. Primarily, young Croats focused much more on SOCIAL ADVANCES of Yugoslavia, as opposed to its political, economic or ethnic characteristics, which were central to textbook and newspaper accounts. Individual presentations of Yugoslavia most often contained positive images of a society that functioned better socially. In fact, descriptions of good lives were unparalleled in their ubiquity among individual accounts. Nearly all respondents provided examples of "lay people" like their parents having better lives, having jobs and/or regular salaries or easily getting credits to buy cars or build houses. Other descriptions of good lives were not as ubiquitous but they were still more prevalent than the great majority of negative frames on Yugoslavia. This, for example, included the descriptions of a life in which people's needs were satisfied and they enjoyed security or the idea of the affordable amenities (descriptions of a life in which people could afford more, even some luxuries like vacations or eating out, often with less money), as well as 
praises for greater workers' rights in Yugoslavia. Many of these elements are contained in the quotes below.

... when it comes to jobs and life, standard, they [parents] were probably better off than now. I think so. Well, they then bought this, let's say big, apartment, with two children and all that somehow. That was for them...normal, they had to take out credit and all that, but they could, simply, afford this on two salaries, let's say ordinary, middle-level salaries... with some sort of clerical jobs, they could afford to buy a big apartment and, I don't know, they could live with two children. Therefore I think it was much easier then than it's now.

(Dzeri, male, transitional generation, college)

They [parents], immediately afterwards, after [finishing school] they got jobs and kept those jobs, they worked in the old firm, they could get credits when they wanted...it was great for them. (Tena, female, transitional generation, college)

The same pattern of considerable prevalence - with 30-40 respondents expressing these ideas - held for descriptions of better social relations in Yugoslavia. The respondents emphasized greater equality, greater solidarity and a sense of community, and they described Yugoslav society as a more socially just society (there was no extreme poverty, differences between people were less extreme and labor was rewarded) and as a society in which vulnerable groups (such as the poor or workers) were better off.

[In Croatia today] I find this some kind of polarization negative. There are no more middle classes that existed in Yugoslavia. Everybody was middle-class then. And now there is no more middle class. Or maybe there is, I think there is, but it's very small. You're either, uhm, rich or poor...I think that even those who are middle class are slightly poor. (Ela, female, post-communist generation, college)

There was that spirit of community... more community and cooperation than today...than in neoliberal capitalism. There sure was more cooperation, you know, and community. (Alan, male, post-communist generation, college)

We [as children] were all more or less from families similar...similar in earnings. We didn't have anybody who would stand out with some great stuff and, uhm, anyway you couldn't really buy that great stuff, there was no much of a, uhm, choice. But, I don't know, I think we were, we were more equal, we weren't frustrated by that.

(Karlitos, male, transitional generation, college)

The only less frequent frame attribute of SOCIAL ADVANCES, which was expressed by 
about a dozen respondents ${ }^{30}$, were the more abstract descriptions of general social advancements in social measures in Yugoslavia, such as free education and health system, good social policies and gender equality.

Therefore, positive social perspective, and the idea of good lives in Yugoslavia in particular, clearly formed a hearable silence (Linde 2009) or a noticed absence (Irwin-Zarecka 1994) in institutionalized frames of Yugoslavia. This perspective is completely absent from history textbooks. In newspapers, it was available only in references to good lives and the higher workers' rights located almost solely in reports from Tito's commemorations, where the voice was given to the narratives from-below by "lay people" visiting these manifestations or to the organizers of the commemorations. Despite this absence in textbooks and newspapers, the regularity with which young Croats invoked the social perspective and the idea of good lives speaks to their high salience.

However, some individual accounts were also inconsistent with the idea of good lives or they presented some negative social aspects. Slightly over a fourth of the sample emphasized that, despite everything else, the Croatian standards were higher than Yugoslav and several respondents linked problematic Croatian lives to the consequences of the Homeland War, rather than to better social organization of Yugoslavia. Further, four respondents explicitly questioned good lives in Yugoslavia as they believed that the things were the same now and then. Some respondents also described the good living in Yugoslavia as illusory (it only appeared as such to people who did not know any better) or specified that only the people who were apolitical or uninterested in public matters lived well. Nevertheless, the ideas supporting good lives in Yugoslavia were much more prevalent than these alternative accounts, making positive social

\footnotetext{
${ }^{30}$ Although, mention by about dozen respondents was actually a good showing for most other ideas describing negative political, economic and ethnic frames.
} 
evaluations of Yugoslavia unquestionably dominant among young Croats.

This holds true even when we look at more explicitly negative evaluations of social aspects of Yugoslavia described in the SOCIAL INJUSTICE meta-frame. About a fifth of respondents mentioned that Yugoslav society was a society in the capability was not rewarded due to the enforced equality and that this was a society in which some groups (ruling elite, army generals or politically suitable functionaries etc.) were more privileged over the majority. The similar numbers of respondents said that the Yugoslav life was characterized by restraints and forced collectivism and conformism. Also, some respondents mentioned that people in Yugoslav society were treated unfairly, as the state took their cattle or produce or exploited their work. Such accounts were rare in textbooks, although they were slightly more frequent in newspapers, where stories of the privileged groups and the enforced equality appeared in form of personal testimonies. Nevertheless, compared with other newspaper frames, this was a rare newspaper frame. Even in negative re-evaluations, then, the social perspective is missing from institutionalized presentations of Yugoslavia.

$\underline{\text { TITO }}$

Young Croats evaluated Tito both positively and negatively, but, above all, they mostly agreed that Tito was the KEY PERSON OF YUGOSLAVIA. In fact, the notion of the tremendous impact of Tito's death on the country and descriptions of his cult of personality were mentioned by about two-thirds of the sample. This is in frequency surpassed only by the idea of good lives in Yugoslavia. Therefore, these images certainly seem to be part of the "core memory” (Linde 2009) on Yugoslavia. Their absence from history textbooks, then, is a as certainly a "hearable silence” (Linde 2009; Irwin-Zarecka 1994).

Moreover, the respondents' descriptions of Tito's cult of personality included more than 
claims about its existence - as, for instance, those rare history textbooks that mentioned Tito were prone to do. The transitional generation also provided lived examples of a life in the country that adored Tito even after his death. For example, the respondents who were younger than two or not even born when Tito died testified to their childhood adoration of Tito, remembered sirens commemorating Tito’s death during their childhood or recounted Tito’s legend from the Yugoslav textbooks (e.g. anecdotes about Tito’s childhood or stories of his war heroism). While such stories never found their place in the Croatian textbooks, they were occasionally reported by newspapers in the later post-Yugoslav period - also in the form of personal testimonies.

...throughout my childhood...there was a cult of personality and Tito this and Tito that...I don't know, I remember very well those sirens, like, [commemorating] when Tito died.

(Picard, male, transitional generation, college)

And we all somehow lost out for not meeting this Tito and for never being the children of flowers and things like that. This, um, when we were children, we all found it real awful that we couldn't cheer Tito with little flags and...wave to him.

(Maris, female, transitional generation, college)

Furthermore, in describing the impact of Tito’s death in 1980, the respondents often invoked similar images such as the image of everybody crying or the idea that the whole country stopped. Neither of these images appeared in textbooks, though some newspapers reported a few testimonies similar to the respondents' accounts. The striking similarity of these stories suggests that the Yugoslav narratives of Tito’s death survived the regime change in 1991 and that these images became part of the Croatian popular memory on Tito. Therefore, it is likely that Tito’s death was such a tremendous event in the lifetime of the Yugoslav populations that it created a “flashbulb memory” (Brown and Kulik, quoted in Pennebaker and Banasik 1997; Conway 1997) - a highly salient and vivid memory for all people alive at that moment (comparable, for example, to John F. Kennedy’s assassination in the USA). 
Indeed, more than a third of the sample believed that Tito kept Yugoslavia together and that his death was a turning point in Yugoslav history, which was also frequently mentioned in both textbooks and newspapers. Therefore, I believe that salience and dramatic character of Tito's death, as well as its perceived long-term impact on lives of the Yugoslav people (cf. characteristics of the most impressionable political events in Pennebaker and Banasik 1997) allowed these images to survive in popular culture and to be transmitted to younger generations. Admittedly, a couple of respondents also claimed that mourning for Tito was enforced by the state and one transitional respondent mentioned that some people secretly celebrated Tito's death, but the overwhelming majority presented Tito's death solely as the period of great grief and shock for the Yugoslav people.

For instance, I found it fascinating, I wasn't told this by my Mom, but by some acquaintance, a woman with whom I chatted about some things in general, and I found it fascinating. Like, she told me she remembered the day Tito died, she went to work and she cried all the way, and everybody she met on the streets was crying. (Bruno, male, transitional generation, vocational)

Other accounts of Tito usually reflected division between positive and negative evaluations that was available from newspapers. Slightly more than a dozen respondents thus focused on presentations of Tito as a dictator or on his responsibility for repression and retributions in Yugoslavia or they called him a criminal. About a dozen respondents also qualified their statements: they characterized Tito as good leader who had poor advisors or who poorly implemented good ideas which then turned into dictatorship or repression.

...Tito was the greatest politician in this region ever, but he was at the same time the greatest war criminal in the region...He was, uhm, masterful politician, which isn't necessarily a positive trait, he was a master in politics, in real politics, but he also knew for many crimes and he was responsible for deaths of perhaps tens of thousands people...

(Puki, male, post-communist generation, vocational)

...but you don't think so much about that, for example, he kills several people because they opposed him, but we celebrate him because that isn't-, he is our Tito. So that, one should, one 
should say that he was a criminal and that he persecuted people, but then again, Yugoslavia was created on a great idea, it's just that it all failed along the way, in dictatorship.

(Rina, female, post-communist generation, college)

More respondents, however, presented clearly positive portrayals of Tito. For example, about a half of the sample talked about Tito being man of the people and being truly loved. Similarly, Tito’s international connections and respect were also often mentioned, where many respondents repeated the same story of Tito’s funeral which was visited by numerous world statesman and dignitaries. Some also claimed that he made Yugoslavia a significant force at the world political scene. Slightly less than a third of the sample claimed that Tito was great or historically significant man. About a dozen respondents also talked about celebrities with whom he associated or glamour that surrounded him in Yugoslav public life.

[Tito was] our man, worker, soldier, war comrade and peasant, that is, like all in one, so this is why people loved him. Because he was from the people, for the people, let's say it like that. So, this is why people loved him.

(Ivana, female, post-communist generation, college)

Tito's funeral, it occurred me that many people came to Tito's funeral. It's a fact that everybody cried. And all the statesmen that came, there was many of them. The fact that these people respected him, that's fascinating.

(Draven, female, post-communist generation, college)

... I can't say that I have a clear opinion on Tito because, uhm-. But I think he was probably the most significant, uhm, the most significant politician who ever was, who ever lived in this region and never, uhm, these people never had such an influential and powerful, uhm, leader as him. (Karlitos, male, transitional generation, college)

Therefore, negative frames on Tito generally took a second place in accounts of two postYugoslav generations compared with more positive frames. Such a situation differs from impression left by institutionalized memories on Tito, where, on the one hand, the textbooks mostly avoided talking about Tito, and, on the other hand, the newspapers played much more on the Tito controversy. 


\subsubsection{Generational and Educational Differences in (Aggregate) Individual Frames}

Individual frames examined in the present study were dominated by social perspective, which was noticeably absent from textbook and newspaper presentations of Yugoslavia. Respondents differed little in this respect. Positive social evaluations were pervasive in all accounts of the Yugoslav past, independently of respondents' differences, including class differences. At the same time, influence of negative political, economic and ethnic re-evaluations of Yugoslavia, dominantly institutionalized in history textbooks and newspapers, was limited. Although such accounts were available from many respondents, they were not so widely shared as the positive social evaluations and they were often simplified.

A limited success of institutionalized frames on Yugoslavia also resulted in a greater variety of their reception (acceptance or rejection) among various segments of young Croats than that was the case with positive social perspective. Indeed, an uneven reception of negative reevaluations of Yugoslavia was evident even from minor negative social evaluations, which followed the same pattern as the institutionally dominant negative political, economic and ethnic re-evaluations. In most cases, the greatest difference that emerges in reception of negative institutionalized political, economic and ethnic frames of Yugoslavia is not the generational, but the educational difference.

In fact, education fragments reception of institutionalized frames within generations and it also trumps differences across generations. First, within each generation, the college-educated ${ }^{31}$ respondents used the frames presenting negative re-evaluations of Yugoslavia more than their vocationally educated counterparts. Second, this educational difference transcended any generational differences - the college-educated respondents in post-communist generation were more similar to the college-educated members of transitional generation than they were to the

\footnotetext{
${ }^{31}$ For sake of simplicity, this term includes both those with finished college-track high school or college.
} 
vocationally educated members of their own generation.

Thus, college-educated respondents of both generations used negative non-democratic and anti-capitalist evaluations of Yugoslavia or referred to centralization in Belgrade more than their vocationally educated counterparts. Similarly, many descriptions of Yugoslav

REPRESSIVENESS (e.g. persecutions of the opposition or religious discrimination) were used more by better-educated respondents. Likewise, the CROATIAN VICTIMIZATION frame was also invoked more by the college groups than by their vocational counterparts.

Considering that historical education of the vocational pupils is neglected in the Croatian educational system (see Chapter Three), a likely explanation of this difference is the lower exposure of the vocational individuals to negative political, economic and ethnic frames of Yugoslavia and, as a result, their poorer "mastery" of such historical information (Wertsch 2002).

This claim is further supported by the greatest gap in the use of negative frames between the post-communist college and the vocational group. The college-educated post-communist group used the negative frames more than any other group, and the vocationally educated postcommunist respondents used them less than any other group. Since the post-communist college and vocational individuals were, at moment of interviews, still close enough to their school years not to start forgetting school information (Jennings 1996), the more-than-average use of negative textbook frames by the post-communist college respondents likely resulted from their greater mastery over the school presentations. In contrast, the vocational respondents' link to schoollearning was less tangible as their high school education focused mainly on their practical rather than academic skills.

However, “cognitive sophistication” (Schuman and Corning 2000) also partly explains the 
educational differences trumping the generational differences, as can be seen from two points. One is the greater questioning of dominant negative frames among better-educated respondents, and the other is that, among all groups of respondents, the post-communist vocational group used the institutionalized textbook frames least.

First, although all college-educated individuals used negative institutionalized frames more, they also questioned or relativized them more. Only the college group, for instance, brought up capitalist developments in Yugoslavia. Admittedly, they did it rarely, but these capitalist developments were not mentioned by any of the vocational respondents. Similarly, the college group mentioned successful elements of Yugoslav economy more often than the vocational group. The better-educated respondents were likewise more aware of elements relativizing some repressive Yugoslav elements and more often suggested, for instance, that the Yugoslav system was better than other socialist regimes. Further, although there is little educational difference in the claims that Croatia was the most developed and the most thwarted Yugoslav economy, the better-educated respondents more often questioned this by saying that Croatia was in better economic position than other republics. Finally, some rare positive frames on Yugoslavia, such as modernizing developments and Yugoslav oppositional position to the USSR and Stalin, were mentioned solely by better-educated respondents. The college group also used more the social advancements frame describing Yugoslav social policies.

All these frames required respondents to evaluate Yugoslavia in more abstract terms, necessitating more detailed information or more complex understandings than this was, for instance, the case when describing more pervasive ideas of Croatian exploitation or good lives in Yugoslavia. Therefore, better proficiency of the college-educated respondents in using lesscommonly-known information on the Yugoslav past or in providing multifaceted perspectives on 
various elements of the Yugoslav regime was likely the result of their better education. In this way, education as an instrument of political socialization may have counterbalanced its influence by simultaneously providing critical skills and additional information which allowed young people not to be "dupes".

This also means that greater knowledge of institutionalized frames, which characterized the college-educated respondents, and the post-communist college group in particular, cannot be equated with their greater acceptance of such frames. While there is truth to this statement ${ }^{32}$, the greater questioning and relativizations of these frames coupled with equal use of positive social evaluations suggest that the better-educated individuals "mastered" (Wertsch 2002) a greater variety of the stories on Yugoslavia, both positive and negative. In contrast, the lower educated respondents, particularly the post-communist group, adopted mainly the social perspective and they were less aware of negative political, economic and ethnic aspects of Yugoslavia.

Second, influence of "cognitive sophistication" can also be seen from the less-than-average use of negative textbook and newspaper frames by the post-communist vocational individuals. For example, the REPRESSIVENESS and CROATIAN VICTIMIZATION frames, which were typically used more widely by all other respondents, were used sparingly by the vocationally educated post-communist generation. Even the idea that Croatia was exploited in Yugoslavia by Serbs, which was one of the most pervasive negative claims about Yugoslavia, was noticeably missing from many of the accounts of the post-communist lower-educated respondents. In fact, when asked explicitly about the political or economic position of Croatia in Yugoslavia, a number of these respondents expressed uncertainty about this issue.

This very rarely happened with other groups of respondents, including the vocationally

\footnotetext{
${ }^{32}$ The post-communist college group, for example, most frequently attributed the blame for the national inequality to the Serbian dominance, which was one of the clearest Croatian textbook messages in the post-Yugoslav period.
} 
educated transitional respondents who were equally poorly exposed to the textbook presentations of Yugoslavia. However, the transitional vocational respondents were older and they spent the last decade of their lives out of school and in labor market, which likely expanded their personal networks and sources of historical information. Therefore, in this case, maturity and life experience (cf. Schuman et al. 1998; Schuman and Corning 2000) possibly increased "cognitive sophistication" of the transitional vocationally educated respondents and compensated partly for their neglected historical education.

All interpretations above suggest importance of education for remembering the Yugoslav past. However, one problem of such interpretations is the impossibility of disentangling educational from class effects, since in my sample most vocationally educated respondents were located among the working classes and most college-educated respondents were from salariat (see the Methods section). Nevertheless, in my interpretation I assume that, since education's main function is access to information, it is more likely that education allowed individuals to adopt alternative perspectives to those obtained in their, say, working class backgrounds and that this should privilege education over class background as a more crucial factor in forming distinct interpretive communities of memory of the Yugoslav past.

Finally, although the generational differences did not emerge as critically separating young Croats as the educational differences did, different generational experiences of these two groups were evident from small differences in their accounts. For instance, the transitional generation's accounts of many aspects of the Yugoslav past were more personal as they drew on their own childhood experiences, such as Tito's cult of personality and life in consumerist scarcity in the 1980s, including shopping for groceries in the neighboring capitalist countries or getting fine chocolate and toys from relatives living abroad. Moreover, these childhood memories of 
Yugoslavia were not unpleasant memories - the great majority of the transitional generation saw their childhood in Yugoslavia as a good memory.

In contrast, it seems that for the post-communist generation the past of the Homeland War, happening during the earliest years of their lives, was more often seen as more important than the Yugoslav past, despite the transitional generation being truly a war generation. ${ }^{33}$ For example, with one exception, the members of post-communist generation were the only ones attributing current unsatisfactory socio-economic situation in Croatia to the consequences of the Homeland War. In addition, although both generations denied any kind of nostalgia, the transitional generation more often claimed that Yugoslavia was something that should stay in the past and that they would not go back despite better social conditions, whereas more members of the postcommunist generation placed greater emphasis of not wanting to go back because now the Croats had their own independent state. Finally, for some members of post-communist generation, the Homeland War was also their first association to Yugoslavia.

However, the Homeland War was not a topic I explored in interviews, so these suggestions above should be considered with caution. Nevertheless, I find it interesting that some small generational differences emerge in the statements described above, when none emerge related to regional backgrounds, a sampling criterion which was supposed to capture respondents’ different war experiences. I have not noted any meaningful regional difference in acceptance of negative political, economic or ethnic frames. Small regional differences that existed were for most part inconsistent with expectations of greater acceptance of negative re-evaluations in regions more affected by the war. In addition, these slight differences might also be a function of a small and non-representative sample. Therefore, I cautiously conclude that regional backgrounds did not

\footnotetext{
${ }^{33}$ For instance, several members of the transitional generation claimed their lives and childhoods were marked by the war. In contrast, most post-communist individuals were too young to remember the war with any sort of clarity.
} 
create meaningful interpretive communities of memory on the Yugoslav past.

In conclusion, the transitional and post-communist generation's different experiences of Yugoslav period, or the transitional generation's early experience of Yugoslav educational system, did not visibly affect their interpretive frameworks on Yugoslavia. Even though mostly positive memories of the transitional generation's early childhood in Yugoslavia make this period seem less distant to them than to the post-communist generation, neither these childhood memories nor their greater familiarity with the Yugoslav ideology make the transitional generation more or less accepting of negative institutionalized frames of Yugoslavia than the post-communist generation.

In fact, these particular experiences also do not make the transitional generation more aware of some alternative perspectives on Yugoslavia as both generations find positive social perspective on Yugoslavia, which was missing from institutionalized accounts, a considerably more salient interpretive framework of Yugoslavia than negative political, economic and ethnic re-evaluations. Indeed, salience of positive social perspective persists despite all other sociocultural differences among respondents, including class differences. In contrast, acceptance of institutionalized negative frames on Yugoslavia shows more variation. This variation, however, is not generational, but educational, as better-educated individuals across generations were generally more aware of negative political, economic and ethnic frames on Yugoslavia. Nevertheless, pairing this educational difference with pervasive use of positive social perspective suggests that better-educated respondents in general were more knowledgeable about both positive and negative aspects of the Yugoslav past. The lower educated respondents, in contrast, seemed to be mostly aware solely of the positive social perspective. 


\subsection{CONCLUSION}

Findings from individual interviews with members of two Croatian young generations suggest that "core memory” (Linde 2009) on the Yugoslav past consisted of positive social perspectives on the Yugoslav society, particularly of the idea of good lives in the former regime, and of images of the tremendous impact of Tito's death on Yugoslavia and Tito's cult of personality. Negative political, economic and ethnic frames that were central to institutionalized memory on Yugoslavia were available to young Croats, but they played a smaller role compared with social lens of Yugoslavia, particularly among the least educated, and thus most socially vulnerable, subsection of the sample.

Therefore, the individual approach to collective memories focusing on their reception, adopted by the present chapter, complemented the structural approach of the previous two chapters and brought to light two main qualifiers to collective memories of Yugoslavia as produced and institutionalized in Croatian textbooks and newspapers. First, success of institutionalized memories on Yugoslavia was limited as negative political, economic and ethnic frames were mostly available, in simplified forms, among only one segment of young Croats those better educated. The respondents with vocational education did not often use these dominant institutionalized frames as their interpretive frameworks of the Yugoslav past, and some did not use these frames at all. In contrast, positive social frames, which were "hearable silence” (Linde 2009; Irwin-Zarecka 1994) in institutionalized memories on Yugoslavia, were the most salient perspectives on the Yugoslav past among all young Croats, independent of their socio-cultural locations and education.

Further, education both fragmented reception of institutionalized presentations of the Yugoslav past within each generation, and it diminished the generational differences as better- 
educated respondents of both generations used negative institutionalized frames similarly and they used these frames more than their vocational counterparts. Therefore, first, education functioned as a source of information on the Yugoslav past by exposing the college-educated respondents in greater measure to institutionalized presentations of the Yugoslav past (cf. Schuman and Corning 2000, 2006). And second, education trumped generational differences by equipping better-educated individuals with "cognitive sophistication” (Schuman and Corning 2000, 2006). As a result, the college-educated respondents of both generations not only knew more about the Yugoslav past in general (unlike many of the vocational respondents, they were not aware solely of non-institutionalized social perspective on Yugoslavia), but they were also more likely to question or relativize some of the frames they used. This suggests that the bettereducated individuals' relationship towards institutionalized frames was somewhat critical and that they also had access to alternative sources of information.

Despite providing some answers, these findings also raise several questions. First, why did institutionalized memories fail, at least in comparison with non-institutionalized social frames on Yugoslavia, and why did they fail in particular among the least educated young people? Was different exposure to historical information and different cognitive sophistication all that mattered, or were other factors at work? Second, if they were not institutionalized, where did social frames on Yugoslavia come from, and why were they resonant for all young Croats, including those better-educated who were more knowledgeable about the Yugoslav past? The analysis presented in this chapter can only speculate on possible answers. In the next chapter, therefore, I will examine sources of various frames on Yugoslavia and how young people used, evaluated and negotiated these various perspectives that were available to them. The analysis of the next chapter, then, will be more able to provide answers to the questions posed above. 


\section{Chapter 5: Repertoires of Collective Memories and Making Sense of the Yugoslav Past}

\subsection{INTRODUCTION}

In the present chapter, I continue to explore individual approach to collective memories. The previous chapter focused on reception of institutionalized memories of Yugoslavia among young Croats. It demonstrated salience of positive social frames on Yugoslavia, which was a perspective missing from textbook and newspaper accounts. Compared with the widespread use of non-institutionalized social frames, the success of dominant institutionalized political, economic and ethnic frames was limited. In fact, they were predominantly used by collegeeducated respondents, and they were mostly absent from the accounts of the least educated individuals. In the present chapter, I attempt to explain this pattern by examining how individuals negotiated various available presentations of the communist Yugoslavia and how they used them to make sense of their lives.

Individuals’ collective remembering occurs within social frameworks (Halbwachs 1992 [1952]; Zerubavel 1997). This means that collective memories are formed through social interaction (Fine and Beim 2007) or through everyday “doing history” (Tschuggnall and Welzer 2002; Fine and Beim 2007). Individuals make sense of the past in interaction within their social groups (such a family or religious community) and in interaction with institutions of their everyday lives through which they encounter institutionalized memories (such as school or the public discourse) (Beim 2007). Nevertheless, studies of how collective memories are formed through social interaction are rare, and the field could benefit from a more in-depth investigation of how individuals evaluate and use various available perspectives of the past.

Insights from the emerging psychologists’ interest in collaborational or conversational remembering might prove useful for examining this issue further (Harris, Paterson, and Kemp 
12008; Hirst and Echterhoff 2008; Hirst and Manier 2008; Rajaram and Pereira-Pasarin 2010; Hirst and Echterhoff 2012), especially if taken beyond the experimental setting psychologists favor into the everyday world of "doing history”. Some valuable avenues of this research examine what makes some memories more "efficiently" disseminated, while others are forgotten. This work is still not well connected with the mainstream sociological analyses, but some rare researchers have examined how individuals negotiate memories from diverse sources in non-experimental settings. For example, German scholars have examined inter-generational transmission of family narratives of the Nazi past and the competition between these stories and institutionalized presentations of Nazism (Welzer 2008, 2010, 2011). Likewise, Linde (2009) analyzed how an insurance company's employees formed perspectives on the company's past interacting with each other and with the company's official material.

The present study seeks to contribute further to this area of examination. Although my analysis is still a far distance away from full-fledged research on collective memories in social interaction, in the present chapter I move beyond a typical study of reception, presented in Chapter Four, and I examine which presentations of the Yugoslav past young Croats acquired from diverse sources (e.g. family, school, the media), how they appropriated or questioned these presentations and how they used them to make sense of their lives in post-Yugoslav Croatia.

\subsection{REPERTOIRES OF COLLECTIVE MEMORIES AND MNEMONIC COMMUNITIES}

\subsubsection{Repertoires of Collective Memories}

Most individuals today live in heterogeneous societies in which they encounter multiple cultural symbols and acquire diverse cultural skills, which they variously use in making sense of the world around them. For example, Swidler $(1986,2000)$ described how white middle-class Americans selectively used diverse understandings of love acquired from cultural resources 
around them (such as tradition, popular culture, religion...). All these understandings formed their cultural "toolkits” or repertoires of love, but which concept of love a particular individual utilized depended on the best fit for her "problem” at the moment. For instance, when explaining how they fell in love, Swidler's respondents described love as a bond beyond their volition, but in explaining why they stayed together they saw love as a voluntary choice. Lahire (2010) similarly argues for “plural actors” who, in their multiple socializations, acquire plural dispositions to think or to act. These dispositions are neither necessarily coherent nor homogenous but they co-exist together in individuals' repertoires. Which disposition will be “activated” in a particular situation depends on “triggers” and on individuals’ interpretations of that situation.

In the field of collective memories, Wertsch (2002) made similar points. In his analysis of the Soviets' reception of presentations of the past in the totalitarian USSR regime, he used the concept of "mastery” to refer to availability of resources about the past such as knowledge of historical facts or access to particular information. Mastery does not imply any commitment (acceptance or rejection) to the available representations of the past, but only an ability to recall or to use them in various ways. This, then, would be equivalent to Swidler’s (2000) concept of “cultural toolkit” or repertoire of available cultural schemas.

Individuals acquire presentations of the past that form their repertoires through mnemonic communities. ${ }^{34}$ These are groups which provide individuals with social frameworks for remembering, from family and ethnic or religious groups to the state (Halbwachs 1992 [1952];

\footnotetext{
34 "Mnemonic communities" are inseparable from "interpretive communities" discussed in Chapter Four. Still, this is a useful analytic distinction. Interpretive communities are characterized by shared interpretations of the past resulting from shared social locations. Mnemonic communities are communities within which mnemonic socialization or acquisition of collective memories occurs (Halbwachs 1992 [1952]; Zerubavel 1997). Although the mnemonic socialization and the interpretive process occur simultaneously and often within the same groups, I find it helpful to talk about the interpretive communities when talking about social patterns of individuals' memories, and about the mnemonic communities when discussing acquiring and attributing different legitimacy to multiple presentations of the past.
} 
Zerubavel 1997). As individuals simultaneously belong to various mnemonic communities, their repertoires may consist of various stories of the past. Some stories may be complementary though focusing on different dimensions of the same past (for example, teachers describing dictatorship or a religious community sharing their stories of persecutions), but they may also be conflicting. Further, not all elements of repertoires carry equal weight. Some are "appropriated" - accepted and incorporated as relevant elements of individual's life and experiences (Wertsch 2002; Swidler 2000). Such appropriations may also include the hegemonic acceptance of dominant meanings (Hall, quoted in Alasuutari 1999). For example, in Wertsch's study (2002), older Soviet generations, unlike the young ones, reproduced official USSR narratives in their essays on World War Two. However, some elements of repertoires may be "resisted" as individuals have knowledge of them but do not accept them or question them (Wertsch 2002). For example, in the USSR, people were aware of the state's heavy-handed attempts at control of the official history, so they doubted it, although this doubt could not be expressed publicly (Wertsch 2002). But, doubt is not limited to totalitarian societies. Even Swidler's (2000) middleclass Americans were critical of the dominant Hollywood myth of romantic love.

How, then, individuals assess various elements of their repertoires and appropriate some and reject others? In Wertsch’s study (2002), the state’s narratives and public discourse were distrusted because they were seen as ideological, whereas family or the "kitchen talk" was the space for honest discussions. In Swidler's study (2000), the myth of romantic love did not fit respondents' experiences, so they were disillusioned and then skeptic towards it. The postYugoslav Croatian society can been seen as somewhere in-between these two cases - it was transitioning from a totalitarian context via a semi-authoritarian regime and going towards more a pluralistic society, but perhaps not quite there yet. Therefore, the present chapter examines 
how, in this context, young Croats evaluated and appropriated or resisted presentations of the past transmitted through various mnemonic communities.

\subsubsection{Competing Sources of Repertoires of Collective Memories}

The previous chapter has shown how education affected collective memories, both by exposing individuals to institutionalized presentations of the past and by equipping them with cognitive sophistication in evaluating these presentations. However, the previous chapter has also suggested that some alternative mnemonic sources successfully competed with school in transmitting non-institutionalized accounts of the Yugoslav past. The foremost candidate for this is family (Halbwachs 1992 [1952]; Zerubavel 1997). Indeed, as Halbwachs suggested and later research confirmed, even our early childhood autobiographical memories are co-created within family, and similar process is at work in early adolescence when individuals start integrating family history with larger social world (Reese and Fivush 2008). In addition, research on the collaborational remembering suggests that mnemonic influences are more successful if audiences believe they share the same reality with speakers (Hirst and Echterhoff 2008), which certainly holds for families more than for any other mnemonic community.

Further, research on inter-generational transmission of narratives of the German Nazi past has demonstrated family's privileged position as a source of representations of the past. Young generations, thus, reinterpreted their grandparents' stories by ignoring all "problematic” elements and even re-inventing their grandparents’ behavior in ways that fit with young people’s values based on their internalized negative evaluations of the Holocaust and the German Nazi past (Tschuggnall and Welzer 2002; Welzer 2008, 2010, 2011). Therefore, this research highlighted that family talk is an important and trusted source not only in the cases where it provides alternative narratives to those dis-trusted state ones, as in Wertsch's example above, but also in 
cases where official narratives are accepted and internalized. When competing with the family narratives with their attached emotional relevance, the official narratives, lacking such emotional impact, were pushed aside and the family Nazi past was not acknowledged.

Research on remembering the more controversial past of the communist German Democratic Republic (GDR) has reached similar conclusions. Deutz-Schroeder and Schroeder in 2008 found that young Germans whose parents grew up in the GDR drew on their parents’ stories and compared social aspects of the former regime favorably to contemporary Germany, despite negative re-evaluations of the GDR in German history education and in public discourse (Clarke and Wölfel 2011). Clarke and Wölfel disagree with original authors that the success of social memories on the GDR among young East Germans is due to generally stronger influence of their parents than school. Rather, they argue, such memories also fulfill an identity function for these young people. I will come back to this in the next section, but at this juncture the takeaway point from these findings is that non-institutionalized alternative presentations of the past survived among new generations through everyday communication (for this reason, Assman (1995) calls such memories the “communicative” memories). Hence, both German cases suggest that non-institutionalized or communicative sources, family in particular, may be influential sources of presentations of the past.

In fact, I would suggest that a possible reason why the family stories are particularly credible to young people is because they are stories of personal experience, transmitted by emotionally trusted sources. Personal experiences influence both interpretations of cultural objects (Griswold 1987a; Shively 1992; Liebes and Katz 1993) and the remembering of the past (Schuman and Scott 1989; Scott and Zac 1993; Schuman et al. 1997; Jennings 1996; Schuman and Rodgers 2004). In addition, several studies examining how people make sense of competing 
cultural resources demonstrated relevance of personal experience for plausibility and legitimacy of various cultural narratives. For example, both Gamson (1992) and Perrin (2006) have found that, in focus group settings, anecdotes and personal examples were powerful conversational resources, which were not easily dismissed by other group members, unless opposing personal experiences could be offered. Personal links also most easily evoked emotional responses (Gamson 1992), and they were often more credible than the media stories (Perrin 2006).

Conversely, absence of personal experience makes “other” stories more believable. For example, Irwin-Zarecka (1994) argues that individuals use their experience as a check against plausibility of "official” memory. Cramer Walsh (2004) also suggests that the elite frames on various issues are more successful when aligned with individuals' experiences, but that they are also more easily accepted when individuals have no personal experiences to "interfere" with plausibility of the elite frames or when individuals are insecure or ambivalent about particular issues. This mechanism is further corroborated by evidence from research on collaborational remembering which suggests that presentations of the past are more easily accepted if audience accepts authority of speaker(s) or if they do not have pre-existing experiences, opinions or knowledge of these presentations (Hirst and Echterhoff 2008).

Therefore, if family members present young people with stories of personal experiences in the periods these young people had not lived through (e.g. World War Two or the communist period), then this is a credible and not easily challenged form. In addition, credibility of parents or other family members is further strengthened by a family emotional bond (cf. importance of emotional bonds in Welzer 2008, 2010, 2011). Other members of “communicative” networks such as friends, close acquaintances or work colleagues may not benefit from the same level of emotional credibility as the family members, but their stories of personal experiences still present 
the past in a plausible form.

Further, credibility of personal experiences is strengthened even more if other cultural resources back them up. For example, resonance of personal experiences can be expanded if they can be linked to wider cultural expectations ${ }^{35}$ contained in “collective wisdom” - these are stories that "everyone knows”, such as proverbs, maxims, familiar life situations, etc. (Gamson 1992). Next, the link with the media stories is even more important as it gives personal experiences a wider reach - it allows for the generalization beyond particular personal examples, which then affirms credibility of personal experience (Gamson 1992). However, this link also affirms credibility of the media narratives which are often met with doubt and expectation of bias (Perrin 2006). If there is a misfit between various cultural resources, then this is a battle that the “outside” sources or authorities typically lose (Perrin 2006). For example, if the media discourse does not fit the personal experiences, than the media stories are questioned or transformed, whereas experiences get the benefit of the doubt (Cramer Walsh 2004).

Therefore, in the present study I examine how non-institutionalized or communicative sources of memory, such as family members, competed with institutionalized sources such as school or the media. Both education and the media are supposed to be strong influences on mediated presentations of the past - education due to its authoritative and wide reach (Apple 2000, 2003) and the media due to its supposedly pervasive influence on the public (Gamson 1992; Cramer Walsh 2004). Nevertheless, communicative sources, family in particular, present their images of the past in form of personal experiences, which not only makes such presentations credible (Gamson 1992; Perrin 2006), but it is also bolstered by an emotional

\footnotetext{
${ }^{35}$ In the field of collective memories, wider cultural expectations could be linked to "narrative templates" that are used interpret all stories of the past, despite changes in content and details (Wertsch 2012). For example, the Russian narrative template of "Expulsion of Foreign Enemies" was used both in Stalinist and post-communist textbooks - it is only that different enemies were expelled in various periods (Wertsch 2012).
} 
attachment extended to family members $(2008,2011)$. Therefore, in evaluation and appropriation of available presentations of the past, it matters who presents the past and in what form the past is presented (Griswold 1994). But, it also matters how individuals use these presentations of the past to make sense of their lives.

\subsubsection{What are Appropriated Collective Memories Used For?}

According to Swidler (2000), individuals use culture to solve their problems. In her study, individuals shift between various available cultural understandings of love and use those that best make sense of their lives and relationships. The "problems" that Swidler's respondents are trying to solve are loosely tied to their identities - they use their repertoires of love to guide their actions, but which concept of love will be selected for this purpose depends on "who they already think they are” (Swidler 2000:87). Clarke and Wölfel (2011) find a similar link between individuals' needs to make sense of their lives and appropriation of images of the past. In their interpretation, young East Germans appropriated their family's stories of positive social aspects of the GDR, rather than institutionalized negative accounts of the GDR, because the family narratives on the GDR solved two problems for these young people: they protected their perceptions of self and they gave them tools to deal with their socio-economic concerns.

First, young East Germans used positive re-evaluations of the GDR to protect their selfesteem or positive evaluations of self (Cast and Burke 2002), which were de-valued in the wholesale condemnation of communist East German experiences and culture (Clarke and Wölfel 2011). The use of the GDR past as a "protection” is also seen from another research with East Germans born in the 1970s where Hyland (2011) found that they identified with unified Germany, but at the same time they also celebrated private and the de-politicized memories of their childhood in the GDR, which they saw as valid and non-problematic parts of their German 
identity. In addition, in the studies on young Germans who dismissed the family Nazi past, such re-imaginations of the past served to reconcile young Germans' perceptions of selves as people critical and condemning of the Nazi regime with their need to preserve the family cohesion and justify their emotional attachments to the family members involved in the Nazi crimes (Tschuggnall and Welzer 2002; Welzer 2010).

Second, young East Germans’ use of the GDR images was also a reaction against living in new capitalist insecurities of unified Germany (Clarke and Wölfel 2011). Therefore, the presentations of the past were used here as Schwartz's (1996b) model of society - they expressed individuals' present concerns and helped them think through them. In fact, several other studies have shown how individuals used cultural objects to think through concerns stemming from their socio-cultural positions. For example, members of a small group Cramer Walsh (2004) observed used the media frames to think through concerns stemming from their shared experiences and shared social identities (which were "activated" in their interaction). Likewise, various audiences of "Dallas" used this TV show to think through issues relevant to their own lives (Liebes and Katz 1993). Therefore, young East Germans as well used the past of the GDR to think through socio-economic insecurities of their own lives.

Finally, collective memories are typically also linked to national identities since the nationbuilding elites use narratives of the shared past to develop a sense of we-ness among their constituencies (Cerulo 1997; Olick and Robbins 1998). For example, Bodnar's study (1992) of public memory in the 19th and 20th century America can just as easily be described as a study about the increasing use of the past in the development of the American national identity. Hence, individuals will likely use presentations of the past in construction of their national identities. However, examining how the link between the construction of national identities and the 
appropriated collective memories works is a more complex matter.

On the one hand, an already existing strong national identification will likely serve as an orienting interpretive framework (Griswold 1994; Zerubavel 1997) pushing such individuals towards appropriation of presentations of the past affirming their national identity. On the other hand, the already appropriated ${ }^{36}$ presentations of the past may be used to consolidate or to weaken individual national identifications. For example, Hyland (2011) has found that young East Germans simultaneously identified with the unified German national identity and maintained a seemingly incongruent nostalgic attitude towards their childhood in East Germany. However, her respondents separated these childhood memories from the concept of the East German state. Rather, they used them to further affirm their - more inclusively defined German identity.

In conclusion, whether memories from individuals' repertoires will be appropriated or rejected depends on various factors. First, it depends on sources of these memories. The institutionalized sources such as education and the media may be particularly influential due to their systematic or wide availability (Assmann 1995; Schudson 1989a), but some other noninstitutionalized or communicative sources may prove as relevant competitors, especially if there is a family emotional bond involved. Further, form in which the past is presented matters as well. The educational narratives are backed-up by authority of education as an institution imparting knowledge, and the various media research has confirmed efficacy of the media frames (see in Cramer Walsh 2004). But, on the other hand, stories of personal experience are among the most credible forms of cultural resources (Gamson 1992; Perrin 2006). Finally, if presentations of the past fulfill individuals' needs they will more likely be appropriated. For example, some memories may sustain individuals’ positive self-perceptions (Clarke and Wölfel 2011;

\footnotetext{
${ }^{36}$ Because they may serve some other function such as the preservation of self-esteem.
} 
Tschuggnall and Welzer 2002), they may provide individuals with tools to make sense of their current concerns (Clarke and Wölfel 2011), or they may be incorporated as elements of individuals’ salient national identifications (Hyland 2011).

In the present study I examine repertoires of the Yugoslav past among young Croats and I analyze how these young people evaluated and appropriated or rejected stories available from institutionalized sources such as school or the media and communicative sources such as family. In addition, I also explore how young Croats used appropriated images of the Yugoslav past to make sense of own lives. Therefore, I focus on the following questions:

1) What were main sources of the frames of the Yugoslav past among young Croats, and how did these different sources differently present Yugoslavia?

2) Whose frames of the Yugoslav past did these young people appropriate and whose representations of the past did they question or reject?

3) How did young Croats use appropriated presentations of the Yugoslav past?

\subsection{METHODS}

The present chapter is based on further analysis of 72 in-depth interviews with Croatian transitional (born 1978-81) and post-communist generation (born 1989-91). The analysis in this chapter is focused on particular combinations of various frames (repertoires of frames) for each individual respondent and on respondents' identifications of sources of images of the Yugoslav past they presented in interviews (such as family, school, the media). This strategy is limited by a requirement that respondents correctly identify their sources. This is not always possible, either because respondents are uncertain about their sources, or because they might misremember how they acquired particular information. Nevertheless, such a strategy still allows a deeper insight into interpretive work young Croats employ when assessing various elements of the past, and it 
is therefore useful for examining mnemonic struggles between various available perspectives in one's repertoire of the past.

The present analysis uses repertoires of frames on Yugoslavia as units of analysis. The repertoire for each individual is defined by combination of all frames used by that individual and by a simple or a complex way of presenting these frames. The simple way of presenting frames refers to using only one or a limited number of simple idea elements for a particular frame. The complex way of presenting frames refers to using several idea elements, including those that are more abstract or rarely used or which present various viewpoints within a particular frame. For example, if the frame Anti-capitalist System Proper is represented only by one simple idea such as "it was a socialist system", this is a simple way of presenting this frame. However, if this frame is presented by a more abstract idea such as "Yugoslav system created an artificial economic stability” or if the respondent provided various viewpoints (e.g. both positive and negative aspects of Yugoslav economy), this is a complex way of presenting this frame.

Individuals whose repertoires combined almost all available frames of Yugoslavia and who used complex presentations were defined as individuals with complex repertoires. Individuals whose repertoires mostly used only one or two frames, which were mainly presented in simple ways, were defined as individuals with limited repertoires. The repertoires of all other individuals were in between these two types. In the following analysis, I examine repertoires of frames of Yugoslavia among young Croats, the main sources of these frames and their evaluations and, finally, how the young people used these frames.

\subsection{REPERTOIRES, THEIR SOURCES AND THE USES OF THE YUGOSLAV PAST}

\subsubsection{Repertoires of Frames on the Communist Yugoslavia}

Limited and complex repertoires stand out among individual accounts of the Yugoslav 
past. The limited repertoires, found among about 20 respondents, predominantly focused on simple presentations of positive SOCIAL ADVANCES and TITO, (almost) to exclusion of all other frames. For example, the respondents with limited repertoires talked mostly of good lives and better social relations, described Tito as a historically significant figure, loved by people and internationally respected, and mentioned his cult of personality. Only a few such respondents also described some simple social injustices in Yugoslavia, problematized or ignored Tito and much more strongly invoked negative ethnic frames of Yugoslavia, with an emphasis on negative Serbian role. Nevertheless, the majority of respondents with limited repertoires provided only a positive social perspective on Yugoslavia and a positive evaluation of Tito.

The complex repertoires were rarer as they were used only by about a dozen respondents. These respondents used various social, economic, political and ethnic frames, often presented in complex ways. Thus, they talked about SOCIAL ADVANCES, but they may also have questioned some of its central positive ideas or may have mentioned unfair social relations. Their portrayals of Tito included both positive and negative frames and they may have brought up some rarer Tito's descriptions. They mentioned ANTI-CAPITALIST and NON-DEMOCRATIC SYSTEM, but they may also have relativized some negative aspects or described such systems in terms that are more abstract. The descriptions of REPRESSIVE SYSTEM were chiefly negative, but some also relativized repression. Finally, the respondents with complex repertoires used all four or at least three ethnic meta-frames (FALSE FEDERAL ORGANIZATION, YUGOSLAV UNITY VIOLATED NATIONAL RIGHTS, NATIONAL INEQUALITY, CROATIAN VICTIMIZATION), but they may also have questioned some of them.

A closer examination of individuals with limited and complex repertoires reveals two patterns. The first pattern confirms the finding about educational differences from Chapter Four, 
as respondents with limited repertoires were vocationally educated. In contrast, respondents whose repertoires were most complex and diverse belonged to the college group. The second pattern anticipates one of the findings of the present chapter. The vocationally educated respondents with limited repertoires relied mainly on the communicative sources, mostly their parents, for their images of Yugoslavia. In contrast, the college-educated respondents with complex repertoires used both communicative and institutionalized sources such as school and the media. In the next section, I examine in more detail main presentations of Yugoslavia available from various sources.

\subsubsection{Competing Sources of Memories on the Communist Yugoslavia}

Non-institutionalized or communicative sources, parents foremost among them, were the main sources of presentations of the Yugoslav past among most young Croats examined in the present study. Such sources mainly presented their own experiences of life in Yugoslavia, which reflected a preoccupation with a social perspective and led to a relatively positive evaluation of Yugoslavia as a period of good or better lives. As a result, such a focus on social perspective and good lives in Yugoslavia was also visible in the accounts of most young Croats. This is consistent with a similar finding about young (East) Germans’ memories of the GDR. They also mostly remembered the GDR through their parents' social lens, rather than through negative perspective of school and public discourse (Clarke and Wölfel 2011). Young Croats, likewise, referred to school and the media less than to the communicative sources. When such institutionalized sources were identified, the media images were mostly those of the Yugoslav repression, and school was primarily attributed the frame of Croatian victimization, with a particular focus on the Croatian exploitation by Serbia.

Other frames of the communist Yugoslavia were rarely, if ever, attributed to particular 
sources and I will not discuss them here. I will mention only that Non-Democratic system, for example, was mostly reduced to ideological system, which was the image mainly attributed to old Yugoslav movies that, from today’s perspective, were interpreted as propaganda. The AntiCapitalist frame was most often attributed to parents who shared with their children both their experiences of a corrupt Yugoslav economic system and their opinion that this system still functioned better than other socialist systems or even better than the Croatian system today.

In general, however, young Croats relied more on the communicative sources that presented mostly positive social perspective on the Yugoslav past and positive evaluations of Tito for their images of Yugoslavia. Their use of the institutionalized sources and their dominant negative political, economic and ethnic re-evaluations was limited, and more likely located among better-educated respondents. In the rest of the section, I present a more detailed analysis of these findings.

\section{COMMUNICATIVE SOURCES}

Young Croats overwhelmingly framed Yugoslavia in terms of its positive social characteristics. Such positive frames most often contained images of a society that functioned better socially. These images were most often attributed to their parents, who talked to their children about various aspects of their everyday lives in Yugoslavia and particularly about their better lives, the affordable amenities and social securities of the Yugoslav period. For example, a college-educated member of the transitional generation, Djuro, described sense of security that the “ordinary people” like his parents had in Yugoslavia, and Ivana, a member of the postcommunist generation, referred to her mother’s story of better social relations in Yugoslavia.

...what I am being told today by my folks, lives were better. Lives were better in the sense-.... my impression, it wasn't so much about affluence, it was about my folks not thinking, that is what my old man says, I wasn't thinking about having for bread tomorrow, will I have enough to buy bread, will I have enough to pay utilities or not. He wasn't thinking if he would be able to go to 
the seaside vacation next year...You got an apartment from your firm, sometimes that was not difficult, sometimes more so, sometimes less. My parents got an apartment because they worked for INA [oil company] and... INA had money and built the apartments.

(Djuro, male, transitional generation, vocational)

My mother told me that everybody was equal, there were no rich people, there were no poor people, it wasn't like today where some people have to go through garbage in order to live. (Ivana, female, post-communist generation, college)

Parents were undoubtedly the dominant sources of positive social perspective on Yugoslavia, but stories of other older people, including their grandparents, were similar. Older generations talked about their everyday lives and experiences and described social aspects of Yugoslavia that made it better than contemporary Croatia.

My relatives in particular, there is this saying "it was good in Tito's time". This means that, I guess they believe, because they have lived for a longer time and they saw, they lived in that period and now in this one...That life was better... (Djurdjica, female, post-communist generation, vocational)

My granny says that those times were beautiful because everybody was equal. She never says it was perfect because nothing is ever perfect, but she says it was nice. That people loved each other, that there were no differences. That they all did the jobs for the same money. (Ela, female, post-communist generation, college)

In addition, for the transitional generation, these stories of better lives and other positive social aspects of Yugoslavia were often intertwined with memories from their childhood. These childhood stories in particular focused on the affordable amenities of that period (seaside vacations, consumerist products, etc.), although some other positive social elements were presented as well. Bubo and Sana recollected their early childhood in the following way: I remember, from this period, everything was great, with jeans and jobs so my parents had a lot of vacations and I was, for example, five weeks at the seaside...we could afford much more. I don't know, I got Diesel jeans, for example, my dad bought things for me all the time, every month I could have something new. This is the only thing I remember. (Bubo, female, transitional generation, college)

My parents worked in Borovo [footwear factory], they had great salaries and they built a house, everything with no credits, we never lacked in anything. We went to the seaside for vacation. Today people are always looking if there is somebody who can host them so the vacation is 
cheaper, we never did that before, for example. I don't know, you make your reservations, you go to hotel and you are there for I don't know how long. It's different today.

(Sana, female, transitional generation, vocational)

Positive social perspectives on Yugoslavia were the most prominent frames among parents and older people. However, the parents and older people were also the most frequent sources of the images about social injustices or problematic social elements. To be clear, such negative social perspectives were rare in general and considerably less present than positive social perspectives. However, when they did appear, they were most often attributed to parents, grandparents and older people who, again, talked to younger generations about experiences of their lives. This, for example, included specifying the good lives only for those who were apolitical or talking about the unfair treatment of people in Yugoslavia.

...those who had different opinions from what was the politics, um, they certainly didn't have it good. But those who lived simply, specifically my family who didn't deal with the politics at all or with anything similar, they just worked in some firm, I think it was ok for them.

(Frederica, female, transitional generation, college)

Grandpa and grandma, they shout that it wasn't anything special, that they would take everything from you, that they would just come and take what they needed.

(Ivan, male, post-communist generation, vocational)

In addition to social frames, positive images of Tito and his descriptions as the key person of Yugoslavia were the second most invoked memory of Yugoslavia among young Croats. Negative portrayals existed as well, but these were very rare and even more rarely attributed to particular sources. Therefore, portrayals of Tito that can be attributed to particular sources were generally positive or implied Tito’s relevance in Yugoslavia. The sources of these images were again predominantly the communicative sources such as parents who were, in this case, in greater measure joined by grandparents and other older people. The parents’ stories mostly focused on the lived examples of Tito’s cult of personality and on descriptions Tito's death, which was a tremendous and shattering event both for the country and for the story-telling 
parent.

Even my Mom told me she cried. My Mom is not really that type, she said, um, she had to control herself because she was pregnant with me so this is what the doctors said, but she said it definitely was a shock, I don't know how many days of mourning.

(Hana, female, transitional generation, vocational)

I remember, my Mom told me this often, that when he died, the whole country mourned, that it really was, um, catastrophe, the whole system collapsed. Nobody worked for three days, nobody went to school. But, what's fascinating to me, the way she described it, these people really felt sad, they really cried for him.

(Alan, male, post-communist generation, college)

The parents, grandparents and other older people also often recounted stories implying Tito’s importance in Yugoslavia. However, these stories had a slightly different focus when shared between grandparents and grandchildren, than when shared between parents and their children. Specifically, the grandparents more often expressed their own adoration or closer identification with Tito (as in Puki's and Cvilim's examples below). The parents, on the other hand, even when presenting positive frames on Tito, remained more restrained in expression of their affections. Indeed, as can be seen from Mirko’s account below, a couple of parental accounts of Tito’s lived cult of personality in Yugoslavia suggested an existence of certain counter-discourse to the official Tito adoration among the parents' generation that was never present among the grandparents' generation who more closely identified with Tito.

...my granny as well, she is still alive, she lived by Tito all her life...when Tito was gone, they all thought the world would end.

(Puki, male, post-communist generation, vocational)

For example, my granny, my granny adores Tito, she would never admit Tito had his faults. (Cvilim, male, transitional generation, college)

My Mom told me, um, that they had to learn by heart poems to honor Tito, there were those relay races [in honor of Tito] where everything was determined in advance. They say there were even some mocking songs, um, that the children invented among themselves...

(Mirko, male, post-communist generation, college)

For some respondents the examples of Tito's cult of personality came from other people, 
but for many of the transitional generation these images were more salient as part of their own early childhood experience of living in the country that adored Tito even after his death. Cvilim provided a particularly vivid account of such childhood adoration of Tito. For the postcommunist generation, naturally, these types of memories were not part of their childhood experiences, so their sources were again mostly parents, grandparents and other older people.

So we all so strongly had Tito, we the children, we so strongly had this star, we didn't know the meaning, nor its relationship, we just accepted it... there was a picture, it was a classroom picture...behind it was written in big letters “Follow Tito's path into the future”...we just watched, this was Tito, we love Tito, he is Tito, he is good, he is really good...he loved children. Even I once wanted...on TV, at celebrations children came to Tito and gave him flowers so he kissed them... and I wanted also to give flowers to Tito. Even, because I always liked diving as a kid, I imagined I would take to Tito...I saw under water a red five-pointed-star, so I would dive it out that for him and I would bring it.

(Cvilim, male, transitional generation, college)

Negative political, economic and ethnic perspectives were less often attributed to communicative sources than to school or the media, but some such descriptions were available from the communicative sources as well. For example, parents often provided stories of Yugoslavia’s repressiveness from their own experiences. Many of these stories were the stories of religious repression or of limitations of free speech. Grandparents and other older people provided similar stories, although they were less often mentioned as sources than parents. In addition, for some members of the transitional generation, the stories of religious oppression were intertwined with their childhood experiences.

My parents told me, like, you weren't allowed to get married in the church, nobody could know about that or you would lose your job. I was also, for example, baptized in secret, we were all in secret, we were all in secret because you couldn't do that either. (Zlatka, female, post-communist generation, college)

Some negative sides are, of course, um, those parts that are already communist-like...you weren't allowed to speak, to express your opinion...you would immediately end up in jail, this also happened to my grandpa. And for nothing, he was joking around with boys and right away, when the police heard...he ended up in a dungeon...So, they were talking, in general, I think they mentioned Tito about something, this-and-that and, of course, the police was passing by, he was 
arrested right away and put to dungeon, and then the remained in a dungeon for a couple of months getting beaten up, of course, regularly, every day...

(Lax, male, post-communist generation, vocational)

However, parents and older people, recounting their own experiences, were also the most frequent sources of rare relativizations or questioning the repressiveness frame. For example, some rare parents or older people denied lack of freedoms in Yugoslavia, they downplayed the Communist Party pressures on people to join it and, in particular, they downplayed religious oppression in Yugoslavia. The last was also sometimes intertwined with personal memories of some members of the transitional generation.

My Mom is also a big fan of that period. So she always says that it certainly, certainly was better than today. Lovely, beautiful. And she says...happier and freer. She emphasizes freer. Because today you really...you have to think what you will say, in front of whom, almost what you are thinking in your head.

(Ela, female, post-communist generation, college)

Those who wanted could get married in church with no problems...that was individual matter. So, they could get married and nothing would happen...My father was some kind of a functionary in those times...almost everybody was in the Party then and so, and some didn't get married, but he, for example, normally got married and baptized me and my sister and everything was normal. So the stories about what you couldn't do, these are just stories...So, my father was also some kind of functionary... he did everything normally because he wanted to, we went to church as a child... he was also an altar boy, I was an altar boy, you know, and things like that.

(Zoran, male, transitional generation, vocational)

In addition, the stories of suppression of the Croatian national expression, which belonged to the Croatian victimization frame, were also most often learned from the communicative sources. These stories were also sometimes joined by the stories of the Croatian exploitation by the Serbs, although these particular stories were more often attributed to school.

There were always those stories, 'of course, we spent two nights in prison because we sang The Fairy of Velebit [19 ${ }^{\text {th }}$ century Croatian patriotic song]' and so on, but, um, only after Croatia was formed that we heard those songs so my Dad would tell me then that, for example, you couldn't sing things like that, right, that was like forbidden...Croatness in general was forbidden.

(Tomislav, male, post-communist generation, college) 


\section{INSTITUTIONALIZED SOURCES}

School and the media featured most strongly as sources of the repressiveness and Croatian victimization frames. The media, in particular, was a strong source of the repressiveness frame, competing well with parental stories of experience of repression in this respect. In addition to the stories of the Partisans' war crimes, the respondents most often mentioned various persecutions of the Yugoslav regime as images they acquired from the media. The media descriptions of these persecutions, however, focused more on general aspects rather than on stories of ordinary people's experiences, as was the case with parents and older people.

I: What they [media] say [about Yugoslavia]?...

$R$ : Well, a lot of negative things... more about crimes committed, um, after World War Two. (Stjepan, male, transitional generation, vocational)

I: How media, newspapers, TV, anything, present Yugoslavia today?

$R$ : Well, today in Croatia, it's presented as bad, as something bad, as, for example, Goli otok [notorious island prison], persecutions of opponents, um, lying to the people, dictatorship, censorship...

(Rina, female, post-communist generation, college)

Nevertheless, when reflecting on Yugoslav rather than on Croatian media, a couple of respondents also mentioned some popular Yugoslav TV shows as examples of less-thanrepressive system based on today's interpretations of these shows' subversive elements.

...those series that were filmed, they were mostly anti-state to some-, as much as they could be in those circumstances, but I never understood it, how Miljenko Smoje wasn't imprisoned 20 times for the Little Place or the Big Town [TV shows airing, respectively, in 1969-71and 1978-81, both based on books and script by Smoje]. Fine, the Big Town was less, it was more pro-Communist, than the Little Place, but there were still a lot of anti-state elements in his shows... That's why I said the media were-, to some point they could mock the state a little.

(Ante, male, transitional generation, college)

The media were less frequently sources of the stories on Croatian ethnic victimization, although particular stories of the victimization of certain Croatian individuals (Catholic Archbishop Alojzije Stepinac and political emigrant Bruno Bušić) were attributed only to the 
media and not to any other source.

School or the textbooks, on the other hand, were the strongest source of the Croatian victimization frame. Indeed, the stories of exploitation and the Croatian subordination to Serbia were the ideas most frequently attributed to school in the Croatian period.

Well, we learned something in school, that all money went to Belgrade, from Zagreb to Belgrade, right? Um, and then this money was in Belgrade re-distributed where needed, but most remained in Serbia...

(Dorian, male, post-communist generation, vocational)

I think it [Croatia] was in some subordinated position. But that is again what we probably learned in high school and later, I think that was tr-, I think I was influenced by this as well. (Merkur, female, transitional generation, college)

Teachers were slightly more often mentioned as sources of the repressive frame than of the other frames. But, when this happened, teachers often functioned as older people recounting their own experiences, rather than as representatives of school authority. Nevertheless, some teachers stood out as individuals who took extra effort to convey to their students the stories about the Partisans' war crimes against the Croats. In addition, teachers were sometimes, though not often, attributed positive social descriptions of Yugoslavia. However, in this case as well, teachers talking about their life in Yugoslavia were assessed under a different “discursive frame” (Middleton and Edwards 1990) - they were defined as witnesses, rather than as experts.

School or textbooks, on the other hand, were never identified as sources of positive social frames. The media, unlike school, was sometimes identified as providing positive social frames, though not nearly as much as parents or older people. Most often, it provided images of good lives and social securities, greater solidarity and more relaxed lives. In many cases, these images were based on the old Yugoslav TV shows or movies and, as such, they carried an awareness of then-idealized presentation of life in Yugoslavia. Such an example is provided by Bruno: I think that life...life was presented as very...nice, rose-colored, we are all one lovely state...of 
people, and everything is nice and lovely. Because, um, all those shows airing, I don't know if you, if you remember "Better life" [late 1980s Yugoslav TV soap opera], it showed everything-. It showed one well-to-do Belgrade family in one nice and lovely apartment and...this kind of life problems. Everything was very nice, very funny, very amusing... Brena [one of the most popular Yugoslav pop-folk singer in the 1980s] who united all those people was also some kind of a big pop icon...Yes, I think everything was carefree...everything was brotherhood and unity. "Train in the Snow" [1976 classic children's movie], everybody is working together on removing snow, "The Fellowship of Pero Kvrzica" [1970 classic children's movie], everybody doing something together. That was all very...idyllic.

(Bruno, male, transitional generation, vocational)

Both school and the media were very rarely sources of frames on Tito. In fact, the transitional generation drew most of their school images of Tito from their early years in the Yugoslav educational system, where they were taught the stories of the Tito legend, as exemplified by Bruno and Ante below. For the post-communist generation these types of stories were not part of their school experience, so their attributions of the Tito images to school were much rarer. When this happened, the post-communist generations mostly only briefly mentioned that Tito was leader or ruler of Yugoslavia or, even more rarely, they often vaguely described his historic significance or the international relevance.

We learned, you know, how this period was like, that everything was most lovely, most beautiful. Tito, of course, was some kind of a demigod... (Bruno, male, transitional generation, vocational)

The greatest son of all nations and nationalities. Marshall Tito, the victor over the Germans... (Ante, male, transitional generation, college)

You know what, we didn't do much [in school] that I remember, we only mentioned the NonAligned Movement and that he was the President. (Zlatka, female, post-communist generation, college)

I: Was there any stories about Tito in the textbooks? R: No, only his personal biography. Only his personal biography. His war contributions... (Puki, male, post-communist generation, vocational)

The media were the least often identified source of Tito's representations. When this happened, the media (primarily TV) were mostly attributed positive stories of Tito. These were 
mostly the descriptions of Tito's mourning or even some celebrity-reminiscent features of Tito's life, such as his success with women and the glamour surrounding him.

...that people cried very much, that children cried...I was only a year old, but I remember, I do know about that, crying...I saw that on TV.

(Elizabeta, female, transitional generation, vocational)

You know, like some glam this-and-that, Tito, Sophia Loren and such stories.

(Humito, male, transitional generation, college)

\subsubsection{Credibility of Sources and Appropriation of Frames on Yugoslavia}

The previous section established that communicative sources mainly presented positive social frames as their portrayals of the Yugoslav past. Since more than a third of respondents identified (almost) exclusively the communicative sources (mostly parents) as sources of their frames of Yugoslavia, these individuals were also mostly limited to positive social perspectives. Admittedly, some respondents with limited repertoires also mentioned repression and Croatian ethnic victimization, but in general, most repertoires of respondents who relied solely on communicative sources overwhelmingly focused on descriptions of better lives and better social relations in Yugoslavia. Therefore, these are the frames of Yugoslavia that individuals relying primarily on the communicative sources likely appropriated.

Further, since these individuals with limited repertoires mostly mentioned only the communicative sources and their presentations of the Yugoslav past, it is difficult to talk about any kind of competition between communicative and institutionalized sources in this group. Considering that most such individuals were vocationally educated, it is likely that school as a source of the institutionalized frames was just less available than the communicative sources. The media discourse on this topic likely did not register in light of many respondents explicitly expressing lack of opinion or interest in Yugoslavia. Therefore, the communicative sources were the only ones truly available. In addition, the communicative sources were mostly parents who 
recounted their experiences, which added to their credibility. This argument is further supported by a marginal group of respondents who relied solely on the communicative sources, but who, unlike most their peers, were more negative than positive in their evaluations of Yugoslavia. This was due to their greater focus on repression and ethnic victimization, but this information was, again, imparted mostly by their parents and older people.

In addition, school and teachers were generally not considered as relevant sources of frames of Yugoslavia. Some respondents thought that school or teachers were mostly silent about Yugoslavia. About half of the transitional respondents explicitly talked about a discourse change on Yugoslavia while they were in school. The post-communist generation was, naturally, less attuned to the discourse change, although a couple of respondents noticed a change from silence to talking more (mostly negatively) on Yugoslavia. However, some post-communist respondents also thought that school's treatment of Yugoslavia was neutral. Teachers, on the other hand, were most often dismissed as authorities on Yugoslavia, as a number of respondents believed that their teachers were expressing their own political alignments when talking about Yugoslavia. The media were also sometimes dismissed in a similar manner.

Mnemonic struggles between different sources on the Yugoslav past were, however, more easily seen from some better-educated respondents with complex repertoires incorporating both the communicative and the institutionalized sources. For example, several respondents with complex repertoires also expressed some kind of a critical or a questioning position to some of their sources. In a couple of cases, this critical position was explicitly directed towards their parents’ presumably biased perspective, whether this perspective was overly positive, as with Rina’s parents, or overly negative, as with Humito’s father.

...I learn one thing in history [class], I learn that it's bad, and then I come home and Mom and Dad say we lived better...they [teachers] are mostly fairly critical to it [Yugoslavia], at least 
those more educated ones are, because here you do have more educated [people] who knew what was going on, while, for example, my parents and other parents, who have only secondary education, they didn't have a clue what was really happening.

(Rina, female, post-communist generation, college)

Well, father is fairly negative...he is much more restrictive, much more, much more negative in his views...from my father there is a lot, for example, he has some kind of story, like, Yugoslavia is shit, blah-blah-blah...you know, some kind of a rejection, denial, like...you need to cut all links with the past. That was always ridiculous to me because I know...I saw the photographs and everything, and I saw, you know, you just hear from stories and everything. But, this kind of, that you can't admit, in case somebody is listening, that you were talking something positive about Yugoslavia... in my case, something that differentiated me is that I maybe did accept a bit, I wouldn't say Yugoslavia, but this kind of greater openness toward otherness, differentness. (Humito, male, transitional generation, college)

Some of these respondents also proposed more complex or rare interpretations of the Yugoslav system by which they opposed some common conceptions on Yugoslavia. Humito, for example, identified perspective of the Serbs, who were commonly the villains of the Croatian stories, in the break-up of Yugoslavia, where “...the Croats claim the Serbs were dominant, the Serbs claim that Croats tried to created ethnically clean areas...”. In another example of a rare interpretation on Yugoslavia, Cvilim (male, transitional generation, college) described the Yugoslav socialist regime as atypical in the context of consumerist branding, which he learned in college. Similarly, Zlatka (female, post-communist generation, college) situated the story of better lives into the wider context of unsustainable economic policies, which is an interpretation requiring a more subtle understanding of historical developments in Yugoslavia, and thus likely obtained by better historical education.

Some rare or more complex interpretations of various aspects of the Yugoslav past (e.g. urbanizing and modernizing developments or comparison of the centralization in the Yugoslav and Serbian capital Belgrade to today’s central role of the Croatian capital Zagreb) were also found among respondents who did not have the most complex repertoires. In such cases, however, these interpretations were mentioned by the college-educated respondents or by the 
respondents who professed a particular interest in the Yugoslav history. Such elements were conspicuously absent from the accounts of the vocationally educated respondents with the most limited repertoires. Therefore, such interpretations again seem to result from a better historical education, whether obtained in school or by pursuing personal interests.

By use of critical or the more nuanced interpretations of the Yugoslav past, including both its positive and negative aspects, the better-educated respondents differentiated themselves from most others, and particularly from the vocationally educated respondents with limited repertoires, who mostly appropriated only the perspectives of their parents and other communicative sources. This adoption of the perspectives of the emotionally close communicative sources mostly happened implicitly, as these were the images of Yugoslavia put forward by respondents as trustful images of life in Yugoslavia. In one case, however, such placement of trust was expressed explicitly. Marijana, a respondent with limited repertoire, identified her grandmother's positive perspective as her influence. The grandmother's stories were congruent with her memory of good childhood in Yugoslavia and Marijana therefore distrusted negative stories of other people.

Honestly, I think that today, that people are very rotten and that they are talking about the things they never tried, they never experienced, never saw. Um, so, um, we can talk whatever we want...but those who ....lived in that something, and when they compare things, they see it for untruth because...it's easy to say something bad...but until you've tried it yourself...you can't judge. Personally, I have only nice experiences, nice memories and everything my granny said I also think, I believe things were like that because I partly experienced it myself. (Marijana, female, transitional generation, vocational)

The role of the emotionally close communicative sources is further demonstrated by accounts of few respondents with complex repertoires who, unlike most of their peers, were explicitly negative in their evaluations of Yugoslavia. Some of these respondents clearly identified trusted communicative sources as the reasons for their negative opinion on 
Yugoslavia, which was often linked to the Partisans’ crimes at the end of World War Two.

Tihomir, for example, identified a history teacher who was very negative about Yugoslavia and who greatly influenced his own views. Furthermore, by acknowledging his influence, Tihomir gave this teacher greater legitimacy than to other people, including parents, who mostly talked only of the positive social aspects. For Puki, the negative perspective was caused by negative family experience of Yugoslavia. These stories of the family past at the end of World War Two, mostly attributed to his grandparents, carried greater weight for Puki than the images of good living described by his parents and some other older people around him.

In high school I had a teacher who, um, he was very emotional about the Croatian history and everything and he, although these things were not so much present in textbooks, he completely, um, in a very detailed manner described what happened and this is where I heard for the first time, um, about proportions of what happened at the Bleiburg field, and not only about these crimes, but about those crimes which are not mentioned here...this is still rarely mentioned, I think you don't learn about that even now, the only thing that is mentioned now is Bleiburg... he talked to us a lot about bad things in Yugoslavia...and his opinion influenced mine a lot. So far this is concerned, I say only what it is when I hear other people talking it was good for them, then, well, ok, they didn't have it so bad.

(Tihomir, male, post-communist generation, college)

My grandpa told me this...After that I found out about my granny, that two of her brothers had gone missing in Bleiburg. Of course, this confirmed my, my negative opinion. Then I found out about my grandpa as well, that two of his brothers were killed, he showed me the photographs...for my family Yugoslavia was never good, well, four members of family were lost...and for me Yugoslavia is something most hated in the whole Croatian history. (Puki, male, post-communist generation, vocational)

Therefore, an access to information about Yugoslavia seems to be an important factor influencing how young Croats asses various elements of the Yugoslav past. Those individuals whose access to information was greater, likely due to their higher education, were more likely to suggest both positive or negative interpretations of the Yugoslav past, to use more diverse sources (both communicative and institutionalized), and to be more critical towards some of their sources. In contrast, the respondents with limited repertoires, mostly vocationally educated, were 
more likely to appropriate evaluations of their communicative sources, primarily those of their parents who shared with their children their specific experiences of life in Yugoslavia. As a result, general evaluations of Yugoslavia among such respondents tended to be more positive, or at least, less aware of complexity of available interpretations and perspectives.

In the next section I examine how these appropriated frames of Yugoslavia were used by young Croats. In particular, I examine how Yugoslavia was used in the construction of the Croatian national identity and how it was used as a tool for thinking through current concerns.

\subsubsection{Uses of Appropriated Frames on Yugoslavia}

In Chapters One and Three I claimed that the 1990s nation-building elites sought to affirm legitimacy of the new Croatian regime in opposition to the communist Yugoslavia, which was condemned in political, economic and ethnic terms. Hence, the new Croatian national identity had little space for accommodating the Yugoslav past. In fact, some examined textbooks and newspaper articles suggested that Yugoslavia was one of obstacles on Croatian path to statehood. Further, rather than in the Yugoslav period, the main controversy in constructing the Croatian identity was located in the debates about the Second World War. As reflected in numerous newspaper reports from various World-War-Two anniversaries, on one end were the far right actors who attempted to establish the continuity of the Croatian statehood with the short-lived Croatian Nazi puppet-state NDH in the World War Two, and on the other end of the debate were the actors claiming that Croatia's statehood was based on the antifascist struggle that gave rise to Yugoslavia, and the Socialist Republic of Croatia, after the war.

In interviews with two young Croatian generations, I did not discuss the Second World War, so I am unable to contribute their perspectives to this debate. However, my discussions of Yugoslavia suggest that this period indeed played a smaller role for construction of the Croatian 
national identity. Although the majority of respondents accepted positive social frames on Yugoslavia described by communicative sources and the transitional generation even fondly remembered their childhood in Yugoslavia, there is a disassociation between these evaluations and their national identifications. In fact, this disassociation echoes the findings of Claire Hyland (2011) who found a similar duality in young East Germans’ accounts of the GDR. On one hand, these young people celebrated private de-politicized memories of their childhood in the GDR, but, on the other hand, they explicitly identified with unified Germany. Similarly, the explicit identification of young Croats in the present study was with the current independent Croatia, and not with Yugoslavia, which was relegated to the past.

Well, when I look at it now, maybe it [Yugoslavia] was good in some respects, but I think we're better off now. Because now we're making our own decisions.

(Lidija, female, post-communist generation, vocational)

It was great, all this with Yuga [nickname for Yugoslavia]. But, um, if somebody asked me now if I wanted to go back, I wouldn't say I want to. I don't know why, maybe because I'm used to, now...Croatia is alone and I'd like us to succeed, as any other European country, I wouldn't want to go back to the old or some such Yugo-talk.

(Bubo, female, transitional generation, college)

Indeed, when asked what they would say about Croatia to foreigners, the majority of respondents, and the post-communist generation in particular, mainly emphasized struggle for independence in the 1990s and the creation of the Croatian state. They rarely explicitly incorporated the Yugoslav past into the presented Croatian history, unless this was part of the wider trend of Croatia always being under the foreign rule. Therefore, the Yugoslav past did not seem to be explicitly incorporated into the narrative of the Croatian national identity.

Nevertheless, some Yugoslav frames were incorporated implicitly in ways in which they were used to legitimize new social order in which young Croats lived. Specifically, the frame of Croatian victimization legitimized the collapse of the Yugoslav state and the creation of the 
independent Croatia, and the frame of Yugoslav repressiveness legitimated establishment of the new nation-state as a non-socialist (democratic) and a non-communist (capitalist) order. Admittedly, compared with the widespread use of positive social frames on Yugoslavia among respondents, independently of their generational, regional, educational and class ${ }^{37}$ differences, these frames were less successful. Nevertheless, the Croatian victimization (mainly attributed to school and older people) and the Yugoslav repressiveness (mainly attributed to the media and to parents) were two frames that were, in their simplified forms, more successful among young Croats than other negative political, economic and ethnic frames.

The use of the repressiveness frame for justification of the new order is particularly evident the responses to the explicit question about bad elements of the Yugoslav communism/socialism. In discussion of this topic, the majority of respondents almost regularly switched to discussion of repression and lack of freedoms in Yugoslavia, which were then compared to their current lives in non-repressive Croatia.

Further, the Croatian victimization frame might have particularly sustained a positive selfevaluation of the Croatian identity since for young Croats the break from Yugoslavia meant a new valuation and celebration of the Croatian identity, which was by many considered to have been suppressed in Yugoslavia. In this respect, then, the Croatian case contrasts the East German case as young Croats did not need to use the officially unrecognized social frames to add value to the part of their heritage devalued in public discourse (Clarke and Wölfel 2011). The official discourse already celebrated their Croatian identity and legitimated the break from Yugoslavia.

\footnotetext{
${ }^{37}$ Since the class was intertwined with education in this research, I also looked more closely at 13 respondents who explicitly said that their family lost standard or was worse off today than in Yugoslavia. These respondents were evenly distributed between those with college and vocational education. They were also evenly distributed between salariat, intermediate and working class, but majority of those with higher-class parent in salariat or intermediate class had the other parent in the working-class occupation. All these respondents predominantly framed Yugoslavia in terms of its positive social aspects. Some aspects of Croatian victimization and repressive system were also available, but these were again more concentrated among better-educated respondents. Therefore, it seems that expression of social frames was not a function of particular social or class interests.
} 
This, therefore, may be one ${ }^{38}$ of the factors why many respondents in the present study found Croatian victimization one of the more resonant institutionalized frames.

In addition, another factor contributing to greater resonance of the Croatian victimization and repressiveness frames might be that the main claims of these two frames were also supported by experiences of the communicative sources. Therefore, their credibility might have been increased not by adoption of these frames from school and the media sources, but by their confirmation by the emotionally believable sources such as parents and family members recounting lives in Yugoslavia. As mentioned in the previous section, these emotionally close sources recounting their experiences seemed to be trusted sources of the most widely appropriated images of the Yugoslav past, those of its positive social aspects.

However, another reason why young Croats might have so easily appropriated positive social frames on Yugoslavia was that these individuals used social frames for expression of their socio-economic frustrations or dissatisfactions with the social insecurities of their everyday lives. Therefore, similar to young East Germans (Clarke and Wölfel 2011), young Croats seemed to use the Yugoslav past as a thinking tool about their present concerns. Since these present concerns were situated in the context of Croatian post-communist society struggling with socioeconomic reforms and the capitalist market insecurities - but which was no longer a society of repression or Croatian ethnic victimization - the comparison with social aspects of Yugoslavia was more relevant to these young people’s lives than comparison with its other political, economic or ethnic aspects.

\footnotetext{
${ }^{38}$ Another factor contributing to the greater resonance of the Croatian victimization frame might also be its fit with the wider cultural expectations in the form of the dominant "narrative templates" or the generalized schematic structures predominantly used to describe the Croatian history in various periods (Wertsch 2012). Several authors suggested that the template of the Croatian victimization was used to present the Croatian history in earlier periods as well, including the Yugoslav period (Höpken 1997; Koren, personal communication, June 19, 2012). It is only that in earlier periods different groups were presented as the perpetrators of the victimization.
} 
As a result, all young people were more receptive to incorporating social frames on Yugoslavia into their collective memories than to incorporating political, economic and ethnic frames that, for them, described a period which was no longer their concern. This delegation of Yugoslavia into the irrelevant past is perhaps most obviously seen in reflections of many respondents who claimed they did not discuss Yugoslavia with their generation or their friends. For example, Sana (female, transitional generation, vocational) claimed that she and her friends "mostly look at now and at the future. The things that happened before, well, we would sometimes talk about what was before...but more often we leave it behind us”. In contrast, discussing the social past of Yugoslavia was part of discussing their problematic present.

\subsection{CONCLUSION}

The findings of the present study confirm Swidler's insights (2000) about uses of culture for solving problems individuals encounter in making sense of their lives. Thus, young Croats predominantly used memories of the Yugoslav past to make sense of their lives in a newly capitalist society which struggled with its socio-economic reforms and their effects on the standards and everyday lives of people. Social frames on Yugoslavia, obtained through noninstitutionalized or communicative sources, provided thinking tools which were more relevant to these young people's lives than the frames detailing political, economic and ethnic aspects of Yugoslavia. That the images of the past were indeed mostly used as a thinking tool for solving present concerns is further supported by uses of the Croatian victimization and repressiveness frames. These frames were used much less than social frames, but their uses also served a particular purpose - they legitimated the Croatian social order which these young people accepted as preferable to the old Yugoslav social order.

In addition, the social frames on Yugoslavia were easily accepted by young people partly 
because of communities transmitting these frames and because of form in which these frames were presented to them. Specifically, the social frames were mainly transmitted by communicative sources, especially parents and other family members, who recounted their experiences of life in Yugoslavia. Therefore, the emotional attachment to the family members combined with the credible form of personal experience in which these images of the past were transmitted further contributed to greater resonance of social frames among young Croats. Such a conclusion is further supported by the finding that the most successful institutionalized frames, the Croatian victimization and Yugoslav repressiveness frames, were also supported by the claims of the communicative sources.

Finally, the findings of the present study also suggest relevance of the varying access to information, which was most often the function of educational differences. Specifically, for most respondents with vocational education, there seemed to have been little competition between the communicative and the institutionalized sources of memory on Yugoslavia. First, the images provided by the emotionally close communicative sources were credible as the accounts of personal experiences. Second, these images were also relevant for these young people's present concerns. Finally, these images were the only images that were actually available to them.

Vocational education in the Croatian system neglects history education of their students, providing them with much less information than the college-track high schools, and this information is often presented in more simple or sometimes even more ideological ways. As a result of this lack of information on Yugoslavia in schools, the respondents with the vocational education, or at least those who were not interested enough to do their own research, were rarely able to use school as a source of their images on Yugoslavia. Rather, perspectives from school, if remembered at all, were generally overshadowed by images communicated by parents and other 
older people. The communicative sources, then, were the only sources that were really available and, at that, they were available in the circumstances that made them credible.

However, for those respondents who were more widely exposed to historical information in school, education mattered as provider of "cognitive sophistication" (Schuman and Corning 2000, 2006). Although they also found social frames transmitted by communicative sources salient and resonant images of the Yugoslav past, better-educated respondents relied on the communicative sources less. Instead, they were more likely to use diverse sources of the past or to be more critical of the sources they used. Therefore, there was a greater competition between the communicative and the institutionalized sources for the better-educated respondents who had more diverse images of Yugoslavia at their grasp.

In the context in which the consensus on the Yugoslav past has not been established, yet textbooks present mostly negative re-evaluations, the communicative sources for these respondents may have served not only as sources of alternative images, but also as reminders of discourse that was in the process of being constructed. Young better-educated respondents seemed to have accepted good social aspects of Yugoslavia, communicated to them by their parents and other older people, alongside the existence of negative aspects of Yugoslavia about which they learned in school. In addition, such an additional perspective provided by the communicative sources, although not necessarily fully appropriated and sometimes even explicitly questioned, nevertheless seemed to provide a space for a critical position towards those school narratives that seemed too one-dimensional.

Therefore, the findings of the present chapter suggest that the main power of the communicative sources (such as parents) lies in their emotional availability and in their presentations of the past through stories of personal experience. Such stories were not only a 
credible form of transmitted cultural narratives (cf. Gamson 1992; Perrin 2006), but in this particular case their influence was further strengthened by the fact that they addressed issues that were of personal concern to young people. Thus, they provided these individuals with tools to make sense of their lives.

In addition, the present chapter also demonstrates that communicative sources have a particular power to influence collective memories of the vocationally educated population since their lower exposure to historical facts or to more nuanced historical perspectives makes this population vulnerable to an uncritical appropriation of the only available images of the past. In the case of better-educated or better informed respondents, the communicative sources do not have such power to displace the images of the past acquired through the institutionalized sources (such as school), but they may provide alternative perspectives that nevertheless may prove crucial for a more critical position and for resistance to the top-down narratives of the past. Therefore, in cases where availability of the credible alternative perspectives leads to the questioned legitimacy of some of the narratives of historical education or where historical education was simply unsuccessful with some segment of the population, the top-down narratives of the past will likely fail to compete successfully with the communicative sources. 


\section{Chapter 6: Conclusion}

The present dissertation examined the intersections between institutionalized and individual memories on the Yugoslav past of two young generations coming to age or growing up in post-communist Croatia in the 1990s and the 2000s. This case allowed examining an emergent institutionalization of a difficult past in a country that, in relatively quick succession, experienced transition from a communist totalitarian regime through a nation-building authoritarian regime to a nascent democratic society. The two examined generations were distinct in their early childhood and formative years' experiences of Yugoslavia and the postYugoslav Croatia, but both depended on the secondary sources such as parents, school and the media for their evaluations of the Yugoslav period. Examining how different beliefs on Yugoslavia, appropriated from different sources, gained standing among different segments of these generations and how these young people used the Yugoslav past to make sense of their lives allowed me to explore several issues in both the collective memories field and in the wider area of the sociology of culture.

In this Conclusion, I will first present the findings of this dissertation. Then I will show how these findings inform the Interactional Model of Collective Memories Formation. Next, I will examine how the findings address some specific issues in the collective memories research introduced in Chapter One. Finally, I will discuss how the findings of the present study contribute to the sociology of culture.

\subsection{THE MAIN FINDINGS AND INTERACTIONAL MODEL OF COLLECTIVE MEMORIES FORMATION}

Chapter Two examined the presentations of the Yugoslav past institutionalized in the Croatian history textbooks and newspapers in the 1990s and in the 2000s. This analysis demonstrated that the emergent public memory on Yugoslavia was characterized by a uniform 
interpretive framework negatively re-evaluating Yugoslavia in political and economic terms. This framework focused on the Yugoslav repressiveness and it particularly emphasized the Croatian ethnic victimization. In fact, the latter was the main viewpoint of the most textbooks and of the mainstream journalist discourse. All Yugoslav problems were chiefly discussed under the supposition that Yugoslavia was an obstacle to the Croatian statehood and that the collapse of the Yugoslav regime represented, above all, Croatian national emancipation.

The above paragraph describes the product of mnemonic struggles among various memory entrepreneurs. These struggles occurred in the public arena and resulted in publicly available or institutionalized memories on Yugoslavia. Specifically, this research examined the struggles happening in education and in the media space, and two of their products: the history textbooks and the journalistic discourse, where the latter also serves as an indicator of the public discourse. In Chapter Three, I showed these specific mnemonic struggles were dominated by the memory entrepreneurs close to the 1990s ruling elites who, in the authoritarian context of the 1990s, misused their privileged access to the state institutions and state resources in order to impose their own perspectives on the educational and the mainstream journalistic discourse on Yugoslavia.

As a result, there was little space for the oppositional or minority perspectives, such as the discussions of Yugoslav flaws from a non-nationalist viewpoint or the presentations of social perspectives on Yugoslavia. Whereas the regime change in 2000 to a degree normalized the journalistic uses of the Yugoslav past and democratized the educational institutions, changes in the dominant presentations of Yugoslavia were limited, particularly in the educational system where institutional inertia allowed continued use of the ideological textbooks.

Further, once these perceptions of the past were institutionalized, they also became the 
macro-level of influences on the individual beliefs on the past. This would suggest that the history textbooks and the journalistic/public discourse provided young Croats mainly with negative political and economic re-evaluations of Yugoslavia, focusing on repression and particularly emphasizing the Croatian ethnic victimization. This finding was further supported by the examination of the reported sources of presentations of Yugoslavia among the young Croats in Chapter Five. School was the main reported source of the accounts of Croatian ethnic victimization, and the media were most often identified as providing images of repression.

Moreover, I also identified the exposure to institutionalized memories on Yugoslavia in school as the most important factor affecting whether negative political, economic and ethnic reevaluations of Yugoslavia were elements of individuals’ repertoires on the Yugoslav past. The vocationally educated young Croats, who were least exposed to the institutionalized memories during their schooling, rarely used school or the media as sources of their images of Yugoslavia. As a result, the political, economic and ethnic presentations of Yugoslavia were often not elements of their repertoires. On the other hand, the better-educated individuals, or those who professed interest in history, reported the institutionalized presentations of Yugoslavia as elements of their repertoires.

These educational differences in the availability of the institutionalized presentations of Yugoslavia among young Croats indicate that their influence on the individual beliefs on Yugoslav past was in fact limited. Those individuals who, due to their vocational education, were less exposed to the school presentations of Yugoslavia, used the political, economic and ethnic evaluations of Yugoslavia less often, or they did not use them at all. At the same time, as shown in Chapter Four, all young Croats in the present study, independently of their generational, educational, class or regional differences, dominantly evaluated Yugoslavia in 
positive social terms, which was a perspective missing from the institutionalized presentations of Yugoslavia. Therefore, all young Croats emphasized the idea of good or better lives in the former regime, and paid smaller attention to the political, economic or ethnic perspectives dominating the history textbooks and the newspapers.

The analysis of Chapter Five demonstrates that the main reason why young Croats dominantly presented Yugoslavia in positive social terms, rather than in negative political, economic and ethnic terms, was that the main sources of their presentations of Yugoslavia were communicative sources such as parents and other older people, rather than school or the media. Therefore, the non-institutionalized social perspectives on Yugoslavia were obtained in social interaction within family and other groups to which individuals belonged - at the interactional level of mnemonic communities. In fact, for the young people with vocational education, parents and older people were the only sources of presentations of the past. As a result, these young people's repertoires were limited to the social perspective. The repertoires of the better-educated respondents, on the other hand, were often more complex: they included both the institutionalized and the memories communicated by their parents.

Finally, individual beliefs were also influenced by personal experiences functioning at the micro level. Personal experiences influence individuals' repertoires of collective memories in two ways. One is by providing idiosyncratic experiences of the Yugoslav past as elements of the repertoires. In this research, personal experiences of Yugoslavia were possible only for the transitional generation who spent its early childhood in the Yugoslav period in the 1980s. As shown in Chapter Four, some aspects of the Yugoslav life in this period were certainly vivid parts of their repertoires - for example, members of the transitional generation provided personal experiences of Tito's cult of personality and of the life of consumerist scarcity characteristic of 
the 1980s Yugoslavia. But, there were little other specific generational differences in the accounts of the Yugoslav past between the transitional and the post-communist generation, so it seems that the childhood experiences of Yugoslavia were not a major influence on the young Croats' repertoires of the Yugoslav past.

Furthermore, different experiences of the formative years also did not seem to matter for the individual beliefs on Yugoslavia. During their formative period in the 1990s, the transitional generation experienced both the war for independence from Yugoslavia and the nation-building negative discourse on Yugoslavia at its heyday, but this experience made them neither less nor more accepting of the dominant negative re-evaluations of Yugoslavia than the post-communist generation coming of age in the democratizing period of the 2000s. Therefore, in this case, educational differences, which led to differential exposure to the institutionalized memories, trumped specific generational experiences.

The second way in which personal experiences influence individuals’ repertoires of collective memories is by shaping individuals' interpretive frameworks -their "horizon of expectations” (Griswold 1994) or their “cognitive orientations” (Zerubavel 1997). In this manner, the personal experiences and concerns, which stem from individuals' socio-cultural locations, affect the resonance and salience of various presentations of the past available from individuals' repertoires. In this research, the effect of specific concerns is most evidently demonstrated in the salience of the social presentations of Yugoslavia for all young Croats, independently of their generational, educational, class or regional differences. Despite being noninstitutionalized, these positive social presentations were for all examined individuals the more frequently invoked images of Yugoslavia than the negative political, economic and ethnic presentations institutionalized in textbooks and newspapers. 
As noted earlier, the social presentations of Yugoslavia were mostly provided by parents and older people, but the reason they were so widely accepted despite being non-institutionalized may be traced to the young people's current social insecurities being more resonant for their lives than the more abstract issues of the non-democratic, anti-capitalist and ethnically-unequal Yugoslav society. Therefore, the young people's shared experience of being a socially vulnerable group in a socially troubled Croatian society directed their cognitive orientations towards the social presentations of Yugoslavia, which they could then compare to their own lives in the postYugoslav Croatia, rather than towards the perspectives of institutionalized memories that were no longer relevant for their everyday lives. Figure 6.1 presents these findings within the Interactional Model of Collective Memories Formation.

Figure 6.1: Application of Interactional Model of Collective Memories Formation

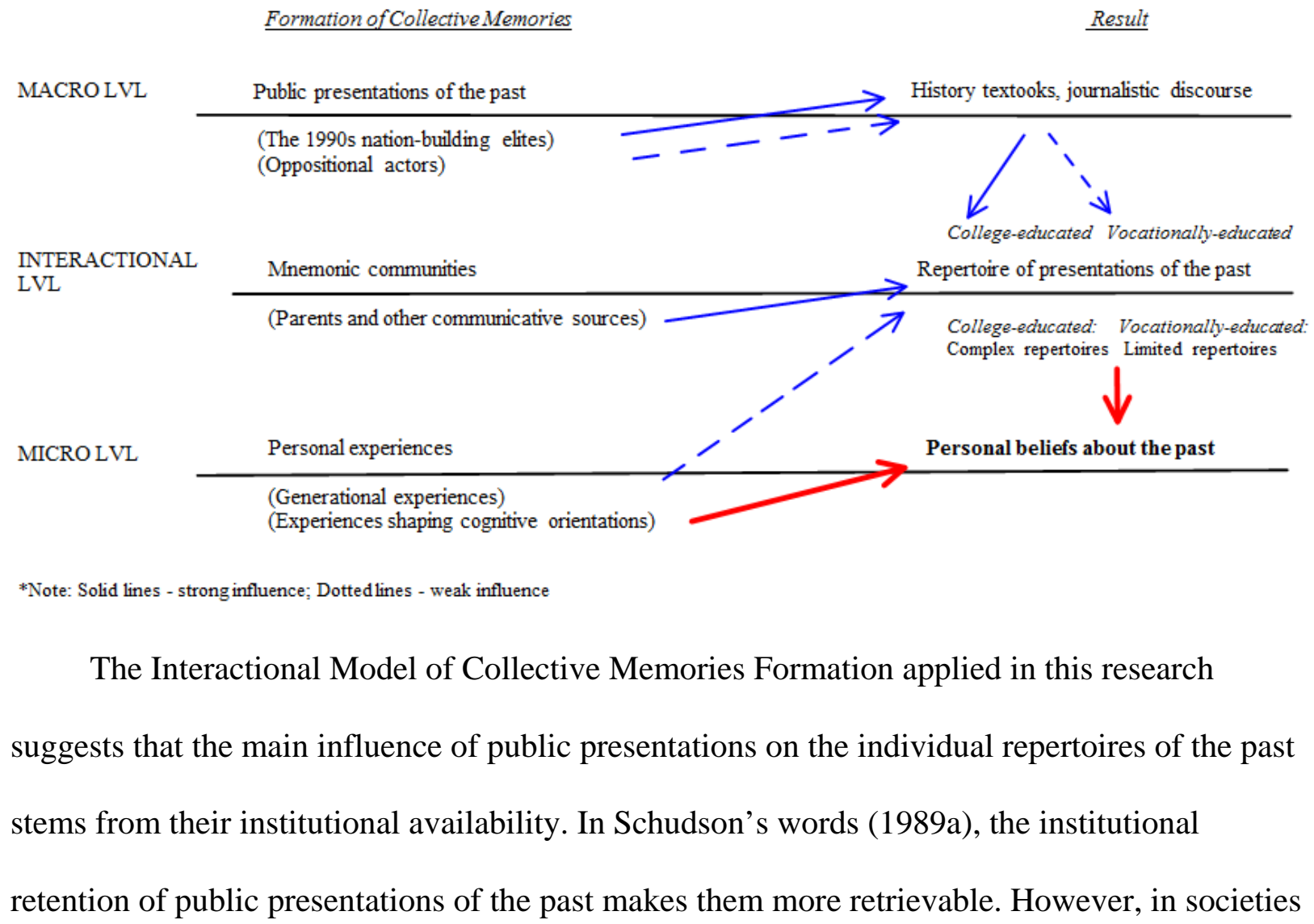


with a divided educational system, such as the Croatian society, this also means that the institutional memories transmitted through the educational system will be less available to the lower educated respondents. Therefore, in cases where a segment of population has limited access or limited exposure to certain channels of transmission of the institutionalized memories, they will rely more on the communicatively available presentations of the past (Assmann 1995) that are transmitted through social interaction. Further, the influence of personal experiences was primarily reflected not in informing the repertoires, but in affecting the resonance (Schudson 1989a) of presentations of the past, obtained through exposure to the institutionalized memories and through social interaction.

The main strength of the Interactional Model of Collective Memories Formation stems from suggesting the main tracks of influences on the repertoires of collective memories. It is weaker, however, in explaining the mechanisms which affect how individuals evaluate various elements of their repertoires and appropriate some and reject the others. One mechanism that is incorporated in the Model is the mechanism of experiences stemming from individuals' sociocultural locations which act as cognitive orientations. These experiences make some presentations more resonant and thus more credible, which increases their likelihood of being appropriated. However, this is not the only mechanism through which individuals evaluate the credibility of presentations of the past forming their repertoires. Specifically, the observations from this research suggest two other mechanisms that are not incorporated in the Model, but which contribute to the understanding how individuals appropriate some available presentations of the past as their own beliefs, while they question or reject others.

The first mechanism is related to the form in which the past is presented to individuals. Specifically, in my interpretation, the credibility of the social presentations of the Yugoslav past 
was further strengthened by them being presented in the form of personal experiences by parents and older people. Several researchers (see, for example, Gamson 1992; Perrin 2006) have found that the form of personal experiences is one of the most credible forms of stories. Further, the form of personal experiences preserves its influence even when it does not involve the experiences of a speaker, but the experiences of the speaker's family and friends. Therefore, in this case as well, experiences of their families and older people were a credible form of presentations of the past (more credible than, for example, the media, which were sometimes accused of bias) and, as such, they influenced the individual beliefs about the Yugoslav past.

The second mechanism is related to education not only giving greater exposure to the more varied historical information, but also by education equipping individuals with cognitive sophistication (Schuman and Corning 2000, 2006). This sometimes resulted in a greater critical stance of the better-educated individuals towards both their parents as sources of the images of the past and towards the publicly available presentations of the Yugoslav past. Their beliefs on the Yugoslav past, therefore, were often more varied and more aware of both positive and negative aspects of the Yugoslav past.

The main contribution of the Interactional Model of Collective Memories Formation to the field of collective memories is the incorporation of the reception and the explicit examination of intersections between institutionalized and individual memories. By incorporating reception, this Model shows that "ordinary people” are indeed active meaning-makers who receive and reinterpret the available cultural material in ways not intended by their creators or producers, and who add their own meanings to the interpretations of the past (Confino 1997; Kansteiner 2002; Wertsch 2002). Thus, this Model confirms the criticisms of the "invention of tradition" or the instrumentalist presentist approach as it shows that individuals are more than just the "dopes” of 
the from-above strategic revisions of the past (Misztal 2003b).

Further, by explicitly examining the intersections of the institutionalized and the (noninstitutionalized) individual memories, the Model can reveal some mechanisms of "resistance” or reinterpretations of the “official” memories (Popular Memory Group 2011 [1982]). Specifically, in this research it demonstrated the importance of the interactional level of mnemonic communities (such as family) as alternative sources of presentations of the past (Beim 2007; Fine and Beim 2007; Tschuggnall and Welzer 2002; Welzer 2010; Clarke and Wölfel 2011), as well as the relevance of socio-cultural experiences which filter the salience and resonance of all available presentations of the past (Griswold 1987b; Zerubavel 1997; Radway 1984; Zelizer 1993). Finally, this Model can also be used as a starting point of more in-depth explorations of other mechanisms which affect the credibility and differential use of available presentations of the past, such as the educational effect or credibility of the form in which the past is presented.

\subsection{ISSUES IN THE COLLECTIVE MEMORIES RESEARCH RE-VISITED}

In addition to the reception of collective memories, which is the key issue of the present dissertation, in Chapter One I introduced some other issues in the field of collective memories that bear relevance to this research. This included how societies deal with a difficult past, the uses of the past for the nation-building, the role of the state and the journalists for the production of collective memories and the related issue of the challenges to the "official” memories and the malleability and the persistence of memories. In this section, I examine these issues as they apply to the case of the Yugoslav past in Croatia.

\section{Difficult Past and Nation-Building}

For post-communist Croatia, the totalitarian Yugoslav regime was a difficult past. Many other post-communist countries dealt with a similar difficult past legally, by de-communization 
laws and demands for transitional justice, or by commemorating the sufferings of this period and the communist victims. However, in Croatia, the de-communization was limited (Milardović 2007). Also, as demonstrated by the analysis of journalistic reports on the Yugoslavia-related commemorations presented in Chapter Two and Three, commemorations of specific sufferings and of the victims of communism (such as commemorations of the 1960s/1970s movements or commemorations of the Croatian Archbishop Stepinac) were unsuccessful. Instead, the battle about the difficult past was led about the past of the Second World War. In this battle, Yugoslavia was mentioned only incidentally and in a very different manner by two opposite sides. On the one side were stakeholders of the commemorations of the communist Partisans' crimes at the end of World War Two, mostly of the far-right persuasion, who questioned the legitimacy of the Yugoslav state since it was established by communist Partisans. On the other side were stakeholders of the commemorations of antifascism who acknowledged the antifascist contributions of the communist Partisans.

In their fragmented nature, these commemorations of the difficult World-War-Two past seem similar to the commemorations of Yitzhak Rabin described by Vinitzky-Seroussi (2002) the difficult past was commemorated in different places, at different times and these separate commemorations targeted disparate audiences. The context of these commemorations also seems to fit Vinitzky-Seroussi's (2002) conditions for fragmented commemorations. First, based on the multiple divisions on the Croatian political scene ${ }^{39}$, I believe that the Croatian political culture could be best described as conflictual, rather than consensual. Next, the issue of World War Two continued to be politically relevant (Milardović 2007). Finally, the stakeholders of both types of World-War-Two commemorations were divided groups with access to resources -leftist political

\footnotetext{
${ }^{39}$ For example, in 2011 Croatia had 116 registered political parties (Hina 2011) at population of 4,407,000 people (World Bank 2012).
} 
elites sponsored the antifascist commemorations, and rightist political elites sponsored the Partisans’ crimes commemorations.

Commemorations of Yugoslavia, on the other hand, were more problematic. For example, as described in Chapter Three, the stakeholders of the 1960s/1970s movements lacked institutional access and were politically marginalized by the ruling elites in the 1990s. In addition, many members of these ruling elites were former members of the communist political structures (Milardović 2007). In this context, the formal de-communization or dissection of the crimes of the established communist regime were not in their interest. Instead, the Yugoslav debate in Croatia was centered on the issues of the Croatian national suppression and ethnic victimization in Yugoslavia, rather than on the violations of human rights, as in many other postcommunist countries. The main project of the 1990s ruling elites was nation-building, and not dealing with the Yugoslav totalitarian past.

This is also evident from the main textbook and journalistic presentations of Yugoslavia in the 1990s. As shown in Chapter Three, the authoritarian political structure of the 1990s allowed the actors close to the ruling elites to attempt to create a top-down consensus (cf. Teeger and Vinitzky-Seroussi 2007) on the Yugoslav past by imposing the Croatian Ethnic Victimization Viewpoint as the main discourse of both the history textbooks and the mainstream newspapers in this period. This viewpoint predominantly discussed Yugoslavia as an obstacle to Croatian statehood and the collapse of the Yugoslav regime as Croatian national emancipation. The alternative Flawed Yugoslav System Viewpoint, which presented the Yugoslav system in a less nationalist framework and emphasized, instead, its problems mainly as problems of a nondemocratic and poorly-functioning anti-capitalist regime, was not at all available from the 1990s textbooks and was available only from the 1990s oppositional newspapers whose circulation and 
reach were limited. Therefore, the analysis of the 1990s Croatia suggests that the ruling elites (mis-)used the Yugoslav past for their nation-building purposes.

\section{Role of State, Mnemonic Struggles and the Malleability and Persistence of Memories}

The analysis above actually fits well the type of analysis conducted by the "invention of tradition” or the instrumental presentist approach to collective memories, which emphasizes how the elites can use the state resources to control the content of the publicly available memories. In fact, this confirms Misztal's claim (2003b) that this approach today is best used for analysis of authoritarian societies. Nevertheless, even in this type of analysis, some criticized flaws of this approach are apparent. First, as demonstrated by the present study’s examination of the reception of collective memories among young Croats, the recipients of these from-above messages about the past are not “dopes”, but they actively reinterpret and construct their meanings. For example, social perspectives on Yugoslavia survived as salient and relevant presentations of the Yugoslav past, despite not being institutionalized.

Further, individuals may be more open to accepting some from-above presentations of the past when these are resonant with their experiences (Irwin-Zarecka 1994). Therefore, the malleability of the Yugoslav past in the Croatian public discourse cannot be explained solely by strategic interests of the ruling elites, even in the authoritarian context. This is part of the story, but such reinterpretations of the past were also part of the non-strategic or meaning-based adaptations to the present needs and concerns (Schwartz 1991; Coser 1992; Olick and Robbins 1998). Specifically, negative re-evaluations of the Yugoslav past were part of the "recovery" of the past silenced in the totalitarian Yugoslav regime, and they also resulted from changed social conditions where post-communist population evaluated previous social order from a perspective of new dominant societal values of democracy and capitalism. 
Finally, this dissertation's findings about the re-emergence of "old” images of Yugoslav President Tito in the public discourse in late 1990s confirm another of the criticisms of "invention of tradition" or instrumental presentist approach - that there are limits to the malleability of the past (Schwartz 1982; Coser 1992; Schudson 1992; Olick 2003a). In fact, the case of Tito presented in Chapter Three illustrates well the conditions for persistence of memory. This case suggests that the past will be more persistent under the following conditions. First, if memory entrepreneurs sponsoring the persistence of some presentation of the past have access to the state resources (Fine 1996; Bromberg and Fine 2002) or if they have access to alternative organizational resources (Armstrong and Crage 2006; Vinitzky-Seroussi 2002). Second, if the memory entrepreneurs are acting in historically opportune moments (Armstrong and Crage 2006) or if they can rely on the salience of the already institutionalized past (Schudson 1989a).

And third, if the cultural object or presentation of the past is highly commemorable because, for example, it can be variously interpreted and appropriated by diverse audiences (Griswold 1987a; Spillman 2003) or it is dramatic in character (Pennebaker and Banasik 1997). All these conditions were satisfied in the case of Tito, thus allowing for his successful commemorations and for the persistence of his positive images in the journalistic discourse since late 1990s despite a general momentum towards negative re-evaluations of the Yugoslav past in Croatian public discourse.

\section{Journalists and Collective Memories}

The final issue that bears relevance to this research is the role of journalists for the production of collective memories. The importance of mass and electronic media as mediators and sources of presentations of the past is an established fact in the memory studies (see, for example, Neiger et al. 2011). Nevertheless, the role of journalists and the news-making in 
presenting the past was not so extensively examined (for exceptions, see Schudson 1992; Zelizer 1992; Edy 2006). Typically, it was assumed that journalists are primarily invested in the hereand-now and not in the past (Zelizer 2008; Kitch 2008). Therefore, journalists were seen to be more involved in the presentations of the past only in two specific cases. One is the commemorative journalism, which is the form in which journalists legitimately and explicitly write about the past (Edy 2006). The second case is journalism in authoritarian and totalitarian regimes where the journalists are forced to promote state propaganda.

In the latter case, journalistic (mis-)use of the past is explicit - and the journalistic bias might be recognized by the "ordinary people" living in such societies. The findings presented in Chapter Three present some such instrumentalist journalistic uses of the past in Croatian newspapers, most notably evident from widely used detailed and explicitly evaluative presentations of the Yugoslav past through the so-called historical contexts in mainstream newspapers in the 1990s. However, in this case the instrumental journalistic use of past was obscured by delegation of authorship of such articles to "authoritative sources" such as academics or protagonists of events in question. This likely raised the credibility of such articles, while hiding the editorial role of journalists who selected only those "authoritative sources" who expressed the perspectives of the 1990s ruling elites.

However, for better understanding of the journalistic role in influencing collective memories, findings of more "normalized" journalistic uses of the past in the 2000s may be more relevant. Specifically, the increasing media freedoms in the 2000s decreased the use of the historical contexts and increased the use of the commemorative articles. However, following conventions of commemorative journalism, journalists privileged the "official sources" and the already highly institutionalized markers (site and dates) of the past. This meant that newspapers 
reproduced the perspectives of the groups which already had better access to the "official channels" or to the resources of institutionalization.

In addition, the democratizing changes also increased the journalists' implicit uses of the past in texts which were overtly not about the past. Thus, journalists often embedded their interpretations of present "newsworthy" events in analogues drawing on certain presentations and perspectives on Yugoslav past or they fed the popular imagery on Tito by asides about his life and rule (cf. Edy 2006; Zelizer 2008). Therefore, in this way as well, journalists influenced the collective memories on Yugoslavia without their memory-work being recognized as such.

\subsection{RESEARCH OF COLLECTIVE MEMORIES AS PART OF SOCIOLOGY OF CULTURE}

In my approach to collective memories, I attempted to overcome the dichotomy between the collectivistic and the individualistic conceptualizations by conceptualizing collective memories as intersubjective memory schemata, formed at the supra-individual level, manifested in individual beliefs about the past and embodied in cultural symbols or publicly available memories. Such an approach also reflects an underlying understanding of culture as intersubjective and supra-individual, encompassing symbolic aspects of both cultural practices and cultural products, and thus existing both at the collective level and in people's heads (DiMaggio 1997; Swidler 1986; Olick 1999).

Therefore, some insights from the study of collective memories can also contribute to some questions raised in the sociology of culture. At this place, I will briefly examine three such questions: how culture works, how individuals use culture and how new generations adapt to social and cultural changes.

\section{How Culture Works}

In his 1989 article How Culture Works, Michael Schudson presents two opposed and, in 
his opinion, unsatisfactory positions on the efficiency of cultural symbols. One of these views sees culture-as-ideology shaping people's actions and the other sees culture-as-toolkit from which people choose the meanings they need for actions. For Schudson (1989a), the first view is overly deterministic and the second one is overly voluntaristic. Instead, he emphasizes that "(1) human beings make their own history and (2) they do not make it according to circumstance of their own choosing” (1989a:156). In my opinion, Schudson overemphasizes the voluntaristic aspect of the culture-as-toolkit position. Looking at culture as a set of resources does not exclude the notion that all forms of perceiving, interpreting and using the culturally available resources are socio-historically shaped (see, for example, recent developments in cognitive sociology: DiMaggio 1997; Cerulo 2002; Brekhus 2007). Nevertheless, Schudson offers a compelling account of the characteristics of cultural objects which affect whether they will efficiently influence actions and beliefs. In his analysis, the most efficient cultural objects or symbols are (1) retrievable (available to their audiences), (2) rhetorically forceful (e.g. memorable or credible), (3) resonant to their audiences, (4) institutionally retained and (5) offer resolution or direct guidance for action.

In the present study, I did not examine how the textbook and newspaper presentations of the past (the symbols of collective memories - the cultural object of the present study) influenced action, but I did examine how they influenced beliefs about the past. My findings support Schudson's analysis, but they also offer some suggestions about the inter-working of the first four characteristics of cultural objects and their interaction with other "points” of Griswold's (1994) cultural diamond (producers/creators, recipients and social context).

First, as Schudson himself notes, the institutionalization of cultural objects makes them more retrievable. This is why in the study of collective memories Assmann (1995) privileges 
"cultural" to "communicative" memories and many other researchers primarily examine the structural or institutionalized memories (Schwartz and Schuman 2005). My study has also shown the importance of institutionalization for retrievability of memory. For example, the heritage of institutionalization of the Tito commemorations in the Yugoslav regime was one of the factors enabling the revival of these commemorations in Croatia in late 1990s.

However, whether a cultural object becomes institutionalized depends primarily on the work of producers/creators and the social context in which they work. For example, the present study demonstrated that the memory entrepreneurs close to the ruling elites of the 1990s successfully institutionalized their perceptions on the Yugoslav past in history textbooks and newspapers because they had access to state resources in the authoritarian political structures. However, the politically marginalized stakeholders of positive Tito's reputation also institutionalized their perceptions of the past in successful commemorations and journalistic discourse in the late 1990s and 2000s. They did not have access to the state resources, but as former Yugoslav officials they had other resources and organizational skills inherited from their previous positions, and they also acted in a historically opportune moment of the more forceful democratic changes in the Croatian society (cf. Armstrong and Crage 2006).

Nonetheless, although institutionalization may increase retrievability, it does not guarantee it. In fact, some other factors may be more important for retrievability of cultural objects than institutionalization. In the present study, this is best exemplified by the differential influence of institutionalized presentations of Yugoslavia on the college-educated and the vocationally educated individuals, where the latter group demonstrated little knowledge of perspectives on the Yugoslav past institutionalized in Croatian textbooks and journalistic discourse. Instead, the lower educated respondents - who, in this study, were also more likely to come from working- 
class families - relied solely on the presentations of the Yugoslav past available to them through everyday social interaction within families and their communities. This would suggest that the institutionalization of cultural objects might have different effects on recipients in different social locations.

Further, the non-institutionalized presentations of the past were available from all individuals in the present study, independently of their educational or other differences. Their retrievability, therefore, did not stem from institutionalization, but from other factors. In this particular case, these were the rhetorical effectiveness and resonance of the non-institutionalized presentations of the past. First, the non-institutionalized presentations of the past were resonant to young Croats because they echoed the concerns that young people in a socially troubled Croatian society found salient for their everyday lives (cf. Griswold 1987b; Zerubavel 1997). Therefore, here, again, the efficacy of cultural symbols depends on the interaction between the characteristics of a cultural object and the social context in which the recipients are embedded.

Second, the non-institutionalized presentations were rhetorically effective because both the speakers and the forms in which they presented the past were credible (cf. Schudson 1989a). The credibility of speakers stemmed from the emotional links between them and their audiences - the speakers were mostly the recipients' parents or family members (cf. Tschuggnall and Welzer 2002; Welzer 2008, 2010). The form in which they presented the past was the form of personal experience, which, in this case, was most often considered more credible than the school and media messages (cf. Gamson 1992; Perrin 2006).

Therefore, the findings of the present study on collective memories also shed light on the conditions "that are likely to make the culture or cultural object work more or less" (Schudson 1989a:160). The characteristics of cultural objects (presentations of the past) that increased their 
efficiency (their influence on the individual beliefs on the past) were four Schudson's dimensions: retrievability, rhetorical force, resonance and institutional retention. However, these four dimensions are interlinked, and their effect also depends on the work of producers/creators within particular social contexts and on the social characteristics and experiences of their recipients.

\section{How Individuals Use Culture}

In her 2000 book Talk of Love: How Culture Matters, Ann Swidler claims that individuals possess repertoires or toolkits of various and not necessarily coherent or unified cultural resources. Further, individuals use these resources to make sense of their lives and to solve their problems within frameworks that are meaningful to them at particular points in their lives and which are congruent with the ideas they have about themselves.

Brown-Saracino and Ghaziani (2009) take issue with some of the work that followed these Swidler's insights. In particular, they claim that researchers have been trying to show how culture is used both to deal with (1) the problems of identity and emotional, political or financial needs stemming from individuals' social positions and with the (2) the organizational problems, mostly in the collective action research (Brown-Saracino and Ghaziani 2009:54). In their own study on the organization of the Chicago Dyke Marches, they show how the second strand of these studies is problematic and how culture, rather than solving organizational problems, can also create and sustain them. Specifically, the organizers of the Chicago Dyke Marches were unable to fulfill their explicit ideological goal of inclusion because they used their organization to affirm their own specific white-young-educated-urban-dyke identity. While in this study Brown-Saracino and Ghaziani have indeed demonstrated how culture is not always useful for solving organizational problems, they also confirmed that culture is indeed used for fulfilling 
individuals’ needs to make sense of their own lives and identities.

The findings of the present study further support Swidler's proposition that individuals use culture to solve their (loosely identity-related) problems. Thus, young Croats variously used their repertoires on the Yugoslav past, but these uses were still mainly in service of making sense of their lives and in supporting their identities. For example, the appropriated institutionalized images of Croatian ethnic victimization in Yugoslavia and the former regimes’ repressiveness implicitly supported the Croatian national identity and legitimized the new democratic and capitalist social order of independent Croatia. However, young Croats predominantly used social, rather than political, economic and ethnic perspectives on Yugoslavia. While the Yugoslav repression and ethnic victimization were no longer relevant for their lives, the Yugoslav social system - and its comparison with the failing Croatian social system - was still very much part of these young people's everyday concerns. Therefore, young Croats used the social perspective on Yugoslavia primarily in an attempt to make sense of their lives in the context of the social insecurities of the contemporary Croatian society.

\section{Generations and Cultural Change}

Finally, this study also offers a glance into the generational mechanisms of social and cultural changes. For many theorists, starting from Mannheim (1952), the exchange of generations in society is one of the main sources of cultural change. For example, Inglehart (2000) claims that societal values shift only when the generations socialized with new values replace the old generations, and Sztompka (1996) attributes many of the problems of postcommunist societies to cultural lag and unsuccessful cultural adaptations of the old communist generations to the new institutional demands.

Swidler's interpretation (2000) of the uses of culture during “unsettled times” is consistent 
with such expectations. During times of upheaval and social change, individuals may continue to use the "strategies of action" that were successful before, but now these strategies no longer solve their problems and, in fact, may lead to cultural maladaptation to the demands of the new social order. Therefore, the new generations, unburdened with old cultural expectations, are more likely to efficiently use culture in solving their problems and in making sense of their lives in the new institutional system.

This indeed, has been demonstrated in this research. Although young Croats repeated their parents' evaluations of Yugoslavia as a system that functioned better socially, and although they used such evaluations to criticize the Croatian social system, these young people were at the same time very much aware that the institutional demands they were facing in the Croatian system were different from those their parents had faced in Yugoslavia. They might have been dissatisfied with that - and because of that, the surveys of values might find that they shared many of their parents' values - but they still knew what they needed to do (and that this was different from what their parents did in Yugoslavia) in order to successfully meet the challenges of a capitalist society. In Swidler's words (1986, 2000), their actions were oriented not by their values, but by their cultural competencies. These new Croatian generations, coming of age or growing up in a new capitalist social order, were competent users of the available cultural resources. Therefore, this dissertation provides additional support to the claims that cultural change requires that generations with new cultural competencies enter the societal stage - and that individuals use culture in diverse and adept ways. 


\section{Methodological Appendix}

This dissertation is based on the textual analysis of Croatian history textbooks and four newspapers published in 1991-2007 and on 72 in-depth interviews conducted with two young Croatian generations between October 2008 and November 2009. In this Methodological Appendix I discuss my connections to the topic, the data collection process and the ethical issues and the concerns of research rigor related to the present study. Following this discussion, I provide list of the history textbooks used in the analysis (Appendix A), list of the newspaper sampling periods (Appendix B), the coding scheme (Appendix C), list of the interview respondents and their characteristics (Appendix D), and the interview guide (Appendix E). Positioning the Researcher

This project on collective memories of communist Yugoslavia among two Croatian postYugoslav generations holds both personal and academic significance for me. In many ways it stems from my own experience of coming to terms with Yugoslav past in the contemporary Croatia as a member of transitional generation. This experience is deeply ambiguous due to my generation's in-between position. On the one hand, we spent our childhoods surrounded with the

ideals (and ideology) of the Yugoslav state, with little awareness of political and ethnic turmoil that was boiling underneath surface. On the other hand, we then experienced those ideals (and ideology) falling apart and others taking their place. This experience shaped many of my academic interests as well, in particular interest in nature of social change and role of culture in societal transformations, as well as interest in mechanisms of social consensus. This project allowed me to pursue these interests. Although it overtly deals with the formation of collective memories on Yugoslavia, this project's underlying questions are the questions about how culture works during times of social change and how individuals use culture. 


\section{Entering the Field and Data Collection}

In recruiting respondents, I primarily used my personal networks, which referred me to candidates fitting the appropriate selection criteria, and I also used the snowball technique to obtain referrals to potential candidates from already interviewed respondents. In addition, in my field year, post-communist generation attended the first year of college, so I introduced the project at several large freshmen classes at the University of Zagreb (in the departments of sociology, social work, physics and electrical engineering) and invited students to participate. In recruiting respondents I encountered difficulties in reaching post-communist generation of the vocational education, as this group was part of neither my personal networks nor of the networks of the college-educated post-communist respondents. However, I contacted the Croatian Chamber of Trades and Crafts and they referred me to their regional and local offices through which I was able to reach former pupils of vocational high schools.

All interviews were conducted in the Croatian language and they typically lasted 60-90 minutes with the transitional respondents, and 30-60 minutes with the post-communist respondents. In majority of cases, interviews were conducted in coffee shops of respondents' choosing. All interviews were audio-taped and transcribed in full, either by myself or by the paid transcribers. The transcripts were entered and coded in Atlas.ti software for the analysis of qualitative data. The history textbooks and the newspapers were available through the Croatian National and University Library (NSK), and the late 2000s issues of the newspapers were available online. Scans of relevant pages and articles were entered and coded in Atlas.ti.

\section{Ethical Issues}

The analysis of history textbooks and newspapers is the analysis of publicly available material so it does not involve ethical concerns. The interviews collected reflections that some 
respondents may construe as political issues, but they cannot be interpreted as harmful. All respondents were over 18 and their names were not recorded. Before the interviews, the respondents were provided with a Study Information Sheet. I told them they were not obliged to participate in the study and that they can withdraw at any moment and, before I started taping the interview, the respondents were asked to give an oral consent to participating in the research and to the taping. The respondents were not compensated for their participation, although I did typically pay for their beverages in coffee shops where interviews were conducted.

The final issue is the power relations between myself as a researcher and respondents. In the interviews with the college-educated members of the transitional generation, to which I also belong, I was generally treated as an equal. However, in the interviews with members of the younger post-communist generation, many respondents tended to use the polite form of address and they would revert to it automatically during the interview, even though I told them to use the informal form. One reason for that is obvious: I am older and in position of some authority, so it was natural for them to use the polite address, even if this seemed awkward to me. However, this also happened with some members of the transitional generation of vocational education. Therefore, despite similarity in age, they seemed to evaluate my education and background as indicators of difference in status and preferred to keep a distance by using the polite form of address.

This research project was approved by two ethics committees: by the Indiana University Institutional Board Review (Study \#08- 12835) and by the Ethical Committee of the Sociology Department at the University of Zagreb, Croatia. It was also co-funded by the Doctoral Dissertation Improvement Grant (\#0825225) of the US National Science Foundation (NSF) and by the Grant for Doctoral Students of the Croatian National Science Foundation (NZZ). 


\section{Issues of Research Rigor: Generalizability, Validity and Reliability}

\section{Generalizability of Interviews}

As typical for qualitative research, interview sample in this research is not based on random sampling. Therefore, this study's limitation is that its findings are not generalizable within framework of probability-based generalizability. Nevertheless, qualitative researchers shift emphasis to framework of theoretically-based generalizability, and, instead, discuss how the study's findings can contribute to sociological knowledge through use and understanding of carefully and purposively selected cases or samples (Glaser and Strauss 1967; Flyvbjerg 2004; Hammersley and Atkinson 2007; Gobo 2008b).

In the present study, interview respondents were sampled through the maximum variation sampling (Lindlof and Taylor 2002), with a goal of collecting diverse accounts of the Yugoslav past. For this purpose, the respondents were selected based on their generation (year of birth), education and regional background. In the initial research design I planned for total of 60 respondents (five respondents per each cell defined by generation-education-region), but during the course of interviews I expanded the sample to include 72 respondents. This was done in order to make sure that the category of the post-communist vocational respondents with little knowledge and interest in the Yugoslav past was indeed an emerging theoretical category, rather than just failed interviews.

In the end, the sample consisted of a diverse group of young people with various educational and professional profiles and coming from various parts of Croatia. Therefore, I feel confident that I collected a diverse set of accounts on the Yugoslav past, particularly as the sample of 72 respondents is a relatively big sample for an interview project. However, one concern that remains is the issue of self-selection. It is possible that only those young people who 
were particularly interested in Yugoslavia or who were more inclined to discuss it in positive terms were more likely to agree to participate in the research. Nevertheless, as already mentioned, some respondents were very clearly uninterested or not knowledgeable about Yugoslavia. Many of these young people agreed to participate in the research as a favor to myself or to the people who recruited them because they fit the selection criteria. Therefore, I believe that I succeeded in collecting diverse perspectives on Yugoslavia among young Croats and that a perspective not mentioned by any of my respondents is rare in population of these two generations. Hence, the observed patterns of similarities and differences between the respondents' accounts of Yugoslavia can be used as a springboard for further theoretical considerations, especially as these patterns would be difficult to observe from other research designs.

\section{Generalizability of History Textbooks and Newspapers}

Generalizability of history textbooks and newspapers is less of a concern. The textbooks included the whole population of textbooks published in Croatia in the examined period (all first editions and later editions if the first edition was modified). Newspapers were represented by four newspapers about which there is a general consensus that they were main mainstream and oppositional newspapers in the 1990s. I sampled newspaper articles by examining all articles published during the critical discourse moments, that is, in all periods more likely to feature public debate on Yugoslavia (see Methods section in Chapter Two and Appendix B for details). However, I also checked validity of the chosen critical discourse moments by examining all issues of one of the examined dailies (Vjesnik) in the 1990s for potentially missed periods of press debate on Yugoslavia. 


\section{Validity of Choice of Generations}

As explained in more detail in Chapter One, choice of ž birth cohorts 1978-1981 and 19891991 as two separate generations is based on their very distinct period and cohort experiences. Specifically, the transitional and the post-communist generation are separated by experience of Yugoslavia (childhood experience of Yugoslavia plus early formal schooling in the Yugoslav educational system vs. no experience and the post-Yugoslav schooling), by experience of the Homeland War (experience of adolescence vs. experience of toddler years, if any), and by experience of post-Yugoslav discourse (the formative years during the authoritarian 1990s period vs. the formative years in the democratizing 2000s period). These differences justify the assumption that these two groups form distinct generations, rather than just two different birth cohorts (Mannheim 1952) Validity of History Textbooks as Indicators of Official Discourse on Yugoslavia

As explained in more detail in Chapter Two, history textbooks are good indicators of official discourse on the past because they, more than any other institution, fall into domain of the state regulation. In the Croatian case in particular, history textbooks were a valid indicator of official discourse on Yugoslavia due to specific social and institutional context of the 1990s, which resulted in a strictly centralized educational system amenable to political interventions into the content of history curriculum and the approval of the history textbooks (see Chapter Three for detailed analysis).

Validity of Newspapers as Indicators of Public Discourse

Choice of newspapers, rather than other type of media, is guided by both pragmatic and theoretical considerations. First, relative unavailability of other media resources problematizes systematic analysis of other media material. But, even more importantly, the monopolist position 
of the state-owned media outlets throughout the 1990s decreases likelihood that other media perspectives differ from those already presented in history textbooks. Therefore, in Croatian context, newspaper discourse presents the best available indicator of public claims and counterclaims about Yugoslavia.

Reliability of Data Analysis

Reliability is related to the degree of consistency in observation or categorizations of the examined patterns (Hammersley 1992; Lindlof and Taylor 2002). This typically refers to consistency of the measuring instrument or replicability of results (Silverman 2006; Gobo 2008a). It is, therefore, less relevant in qualitative studies where researcher is instrument and studies are usually based on non-repeatable events (such as interviews) (Lindlof and Taylor 2002). Nevertheless, some researchers believe that reliability of qualitative studies is enhanced by rigorous procedure that is made transparent to readers and academic community (Silverman 2006; Gobo 2008a). This, among other things, includes documentation of the data-analysis process.

Coding of textbooks, newspapers and interviews was described in detail in Chapter Two, so I will not repeat this here, but I will briefly sketch the data-analysis procedure. After each interview, I wrote a detailed personal memo on the interview and on my reactions during the interview. The personal memos consisted of field notes and of the summary of the interview. They also included my personal notes and, where applicable, the methodological and theoretical notes prompted by the interview. This was intended to help me monitor personal biases and to provide accurate and complete descriptions of respondents and contexts of their interviews. I also kept a research log, documenting stages in my research, as well as the audit trail memo, in which I noted methodological and analytic decisions during the fieldwork and in the data analysis. 
Further, many methods textbooks suggest that stability of coding categories could be checked by other coder/s to ensure inter-coder agreement or reliability (see, for example, Creswell 2007). However, not everybody agrees that this is useful or practical, or even desirable in qualitative research (Lindlof and Taylor 2002). For example, Rizzo, Corsaro, and Bates (1992:111/112) claim that "inter-rater reliability - especially when it involves comparing judgement of less-informed individuals with those of informed investigators - is of dubious value since agreements do not provide any meaningful corroboration of, nor do disagreements constitute any serious affront to the informed judgments.”

Nevertheless, some kind of check on the coding categories can be useful for their improvement, and in this manner I approached the issue of inter-coder reliability in the present research. I hired an undergraduate student who coded a randomly selected subset of textbooks (11 out of 34 textbooks), newspaper articles (54 out of 313Yugoslavia-related articles) and interviews (10 out of 72 interviews) using my previously established coding categories. She received a coding scheme with descriptions of idea elements (the most concrete coding category), frame attributes, frames and meta-frames (the most abstract coding category). She was further instructed that for each piece of text she codes she should first identify the appropriate meta-frame, and then she should attach each code to one of the idea elements forming the frame attributes.

For the purpose of inter-coder reliability, a requirement that two coders should agree at the level of idea elements and even frame attributes, which are still very concrete statements from material (see Appendix C for examples), is very strict, particularly as the second coder was not familiar with research questions. Consequently, the overall agreement at level of frame attributes (which were aggregated from the idea elements) and idea elements contradicting particular frame 
attributes ${ }^{40}$ was very low: $54 \% .{ }^{41}$ Such a low agreement ${ }^{42}$ also partially resulted from the fact that many of compared frame attributes and the contradicting idea elements were very rare in the examined subset of the material. For example, the conflicting idea element "Croatia was Powerful in Yugoslavia or as Powerful as Other Republics” appeared only once in my codes, but the second coder did not notice such a code, so our agreement in this and many similar cases was $0 \%$.

However, the reason why I required the other coder to use such very specific codes is because I wanted to compare our disagreements on particular codes and to identify if I needed and how I needed to modify them based on our different interpretations. Therefore, after this check by another coder, I went over the frame attributes and the idea elements for which the agreement between myself and the other coder was below $70 \%$ and I noted if the reason of our disagreement was a different interpretation of a code or my own or the second coder's coding mistake. As a result of this examination, I identified several ambiguous or problematic idea elements and frame attributes which were then modified. Therefore, although I did not conduct another inter-coder reliability check after these modifications, the final coding scheme used in the analyses was improved based on the problems highlighted by another coder.

\footnotetext{
${ }^{40}$ The frame attributes were aggregated from the idea elements because, due to great numbers of the idea elements, manually comparing the overlapping codes between two coders at this level was not a manageable task (see idea elements in Appendix C). The idea elements contradicting particular frame attributes, however, were much rarer and therefore I did not aggregate them (in Appendix C these are presented in square brackets with notation “contradicts").

${ }^{41}$ This was calculated using Holsti's method of percent agreement (Neuendorf 2001): 2 x agreement between two coders / (number of units coded by coder $1+$ number of units coded by coder 2).

${ }^{42}$ Aggregating codes at more abstract level of frames would likely improve agreement, but this is not an optimal solution in this case since the coding scheme was later modified in light of the inter-coder disagreements (see next paragraph) and since it would be more appropriate for the second coder to directly code material at the level of frames.
} 


\section{Appendix A: History Textbooks Used in the Analysis}

\section{Primary School (8th grade)}

Perić, Ivo (1992, 1st Ed). Povijest za VIII. razred osnovne škole. Zagreb: Školska knjiga

- $\quad$ The 1993 edition modified, but very slightly in part about Yugoslavia.

- $\quad$ Used by the transitional generation.

Perić, Ivo (1996, 1st Ed). Povijest za VIII. razred osnovne škole. Zagreb: Alfa

- $\quad$ The 1998 edition of this textbook still in use in the early 2000s.

Brkljačić, Maja, Ponos, Tihomir, Samaržija, Zdenko \& Dario Špelić. (2000, 1st Ed). Povijest 8: udžbenik za osmi razred osnovne škole. Zagreb: Školska knjiga

- $\quad$ Used by the post-communist generation.

- $\quad$ Approved for use in period 2000/01-2005/06.

Đurić, Vesna (2002, 3rd Ed*). Povijest 8: udžbenik povijesti za osmi razred osnovne škole, Zagreb: Profil

*The 2000 edition is the 1st edition, but the 2002 edition should be identical.

- $\quad$ Used by the post-communist generation.

- $\quad$ Approved for use in period 2000/01-2006/07.

Koren, Snježana (2000, 1st Ed). Povijest 8: udžbenik povijesti za 8. razred osnovne škole, Zagreb: Profil

- $\quad$ Used by the post-communist generation.

- $\quad$ Approved for use in period 2000/01-2006/07.

Matković, Hrvoje (2000, 1st Ed). Povijest 8 : udžbenik za VIII. razred osnovne škole. Zagreb: Školska knjiga

- Used by the post-communist generation.

- $\quad$ Approved for use in period 2000/01-2005/06.

Kolar-Dimitrijević, Mira, Petrić, Hrvoje \& Raguž, Jakša (2003, 1st Ed). Povijest 8: udžbenik iz povijesti za osmi razred osnovne škole, Samobor: Meridijani

- Used by the post-communist generation.

- $\quad$ Approved for use in period 2003/04-2005/06.

Jurčević, Josip \& Raic, Marija (2004, 1st Ed). Povijest VIII: udžbenik za 8. razred osnovne škole, Zagreb: Alfa

- $\quad$ Used by the post-communist generation.

- $\quad$ Approved for use in period 2004/05-2005/06.

Brkljačić, Maja, Ponos, Tihomir, Samaržija, Zdenko \& Špelić, Dario (2006, 6th modified and extended Ed). Povijest 8: udžbenik za osmi razred osnovne škole. Zagreb: Školska knjiga

- $\quad$ Approved for use in 2005/06 only. 
Bekavac, Stjepan, Bradvica, Marija \& Miočić, Marinko (2007, 1st Ed.). Povijest 8: udžbenik za osmi razred osnovne škole. Zagreb: Alfa

- $\quad$ Approved for use in 2007.

Đurić, Vesna (2007, 1st Ed.). Povijest 8: udžbenik povijesti za osmi razred osnovne škole. Zagreb: Profil

- $\quad$ Approved for use in 2007.

Erdelja, Krešimir \& Stojaković, Igor (2007, 1st Ed.). Tragom prošlosti 8: udžbenik povijesti s CD-om za 8. razred osnovne škole. Zagreb: Školska knjiga

- $\quad$ Approved for use in 2007.

Kolar-Dimitrijević, Mira, Petrić, Hrvoje \& Raguž, Jakša (2007). Povijest 8: udžbenik iz povijesti za osmi razred osnovne škole. Samobor: Meridijani

- $\quad$ Approved for use in 2007.

Koren, Snježana (2007, 1st Ed.). Povijest 8: udžbenik povijesti za osmi razred osnovne škole. Zagreb: Profil

- $\quad$ Approved for use in 2007.

\section{Vocational Three-year High School (1st grade)}

Vujčić, Ivan (1996, 1st Ed). Hrvatska povijest. Zagreb: Birotehnika

- $\quad$ Approved for use in 1996/97-N/A (on the list of approved textbooks in 2001/02).

Đurić, Vesna \& Peklić, Ivan (1998, 1st Ed). Hrvatska povijest od doseljenja Hrvata do naših dana. Zagreb: Profil

- $\quad$ Approved for use in 1998/99-2001/02.

Đurić, Vesna \& Peklić, Ivan (2002, 5th Ed*). Hrvatska povijest od doseljenja Hrvata do naših dana. Zagreb: Profil

*The 2000 edition is the 1st modified edition, but the 2002 edition should be identical.

- $\quad$ Used by the post-communist generation.

- $\quad$ Approved for use in 2002/03-2007/08.

Bekavac, Stjepan \& Štambak, Nikola (2003, 1st Ed). Hrvatska povijest: udžbenik povijesti za prvi razred trogodišnjih strukovnih škola. Zagreb: Školska knjiga

- $\quad$ Used by the post-communist generation.

- $\quad$ Approved for use in 2003/04-2005/06.

Čokonaj, Emil, Petrić, Hrvoje, Raguž, Jakša \& Škiljan, Davor (2003, 1st Ed). Povijest od doseljenja Hrvata do danas. Zagreb: Meridijani

- $\quad$ Used by the post-communist generation.

- $\quad$ Approved for use in 2003/04-2006/07. 
Dukić, Ivan, Erdelja, Krešimir \& Stojaković, Igor (2003, 1st Ed). Hrvatska povijest. Zagreb: Školska knjiga

- $\quad$ Used by the post-communist generation.

- $\quad$ Approved for use in 2003/04-2007/08.

Petrić, Hrvoje (2007, 1st Ed). Povijest (Pregled hrvatske povijesti) - udžbenik za I. razred trogodišnjih srednjih strukovnih škola. Samobor: Meridijani

- $\quad$ Approved for use in 2007.

Vocational Four-year High School (2nd grade)

Vujčić, Ivan (1996, 1st Ed). Povijest (Hrvatska i svijet 2). Zagreb: Birotehnika

- $\quad$ Used by the transitional generation.

- $\quad$ Approved for use in 1996/97-N/A (on the list of approved textbooks in 2001/02)

Mirošević, Franko, Šanjek, Franjo, Macan, Trpimir \& Mijatović, Anđelko (1997, 1st Ed).

Povijest. Zagreb: Školska knjiga

- $\quad$ Used by the transitional generation.

- $\quad$ Approved for use in 1997/98-N/A (on the list of approved textbooks in 2001/02)

Đurić, Vesna \& Peklić, Ivan (1999, 1st Ed). Hrvatska i svijet od sredine XVIII. do kraja XX. st. Zagreb: Profil

- $\quad$ Approved for use in 1997/98-2001/02

Đurić, Vesna \& Peklić, Ivan (2002, 3rd Edition*). Hrvatska i svijet od sredine XVIII. stoljeća do naših dana : udžbenik povijesti za drugi razred srednjih škola. Zagreb: Profil

*The 2000 edition is the 1st modified edition, but the 2002 edition should be identical.

- $\quad$ Used by the post-communist generation.

- $\quad$ Approved for use in 2002/03-2007/08

Čokonaj, Emil, Petrić, Hrvoje, Raguž, Jakša \& Škiljan, Davor (2003 , 1st Ed). Povijest 2:

Hrvatska i svijet od kraja 18. do potkraj 20. st. Zagreb: Meridijani

- $\quad$ Used by the post-communist generation.

- $\quad$ Approved for use in 2003/04-2006/07.

Samaržija, Zdenko (2003, 1st Ed). Hrvatska i svijet 2. Zagreb: Školska knjiga

- $\quad$ Used by the post-communist generation.

- $\quad$ Approved for use in 2003/04-2007/08.

Čokonaj, Emil, Petrić, Hrvoje, Raguž, Jakša \& Škiljan, Davor (2007). Povijest 2: Hrvatska i svijet od kraja 18. do potkraj 20. st. Zagreb: Meridijani

- $\quad$ Approved for use in 2007.

\section{College-track High School (4th grade)}

Perić, Ivo (1993, 1st Ed). Hrvatska i svijet u XX. st. Zagreb: Školska knjiga

- $\quad$ Used by the transitional generation. 
Perić, Ivo (1997, 1st Ed): Povijest: za 4. razred gimnazije. Zagreb: Alfa

- $\quad$ Used by the transitional generation.

- $\quad$ Approved for use in period 1997/98-2005/06.

Vujčić, Ivan (1998, 1st Ed). Povijest: Hrvatska i svijet u XX. stoljeću: udžbenik za četvrti razred gimnazije. Zagreb: Birotehnika

- $\quad$ Used by the transitional generation.

- $\quad$ Approved for use in period 1998/99-N/A (not on the list of the approved textbooks in 2005)

Leček Suzana, Agičić, Damir, Najbar-Agičić, Magdalena \& Jakovina, Tvrtko (2002, 4th Ed*). Povijest 4. Zagreb: Profil

*The 1999 edition is the 1 st ed, but the 2002 edition should be identical.

- $\quad$ Used by the post-communist generation.

- $\quad$ Approved for use in period 1999/00-2007/08.

Matković, Hrvoje \& Mirošević, Franko (2001, 1st Ed): Povijest 4. Zagreb: Školska knjiga

- $\quad$ Used by the post-communist generation.

- $\quad$ Approved for use in period 2001/02-2007/08.

Kolar-Dimitrijević, Mira, Petrić, Hrvoje \& Raguž, Jakša (2004, 1st Ed). Povijest 4. Samobor: Meridijani

- $\quad$ Used by the post-communist generation.

- $\quad$ Approved for use in period 2004/05-2007/08.

Bubanj Valentić, Davorka (2007, 1st Ed). Povijest 4: udžbenik za IV. razred gimnazije. Zagreb: Birotehnika

- $\quad$ Approved for use in 2007.

\section{4th grade Primary School Textbooks for the subject Nature and Society used by the Transitional and the Post-communist Generation}

Mažuran, Ive, Dorofejev, Velimir \& De Zan, Ivan (1988, 4th Modified Ed). Moja domovina: udžbenik prirode i društva u četvrtom razredu osnovne škole. Zagreb: Školska knjiga

Matas, Mate, Jukić, Stanko \& Medovka, Franjo (1998, 1st Ed). Naša domovina Hrvatska: udžbenik za IV. razred osnovne škole. Zagreb: Profil

De Zan, Ivan, Jelić, Tomislav, Klarić, Zoran \& Vranješ-Šoljan, Božena (1998, 1st Ed). Moja domovina Hrvatska: udžbenik prirode i društva za četvrti razred osnovne škole. Zagreb: Školska knjiga

Vrgoč, Danice \& Žugec, Vesna (2001, 1st Ed). To je moj svijet 4: udžbenik za prirodu i društvo za četvrti razred osnovne škole. Zagreb: Alfa 


\section{Sources of the data on the approved textbooks:}

Barunčić, Julija and Križe, Željka (2006). "Domovinski rat u udžbenicima povijesti”. Časopis za suvremenu povijest 38(2):625-651

MZOŠ (2007). Katalog odobrenih udžbenika za osnovnu školu, gimnazije i srednje strukovne škole u školskoj godini 2006/2007. Zagreb: Ministarstvo znanosti, obrazovanja i športa. Retrieved from www.ffst.hr/ irenavz/sadrzaji\%20predavanja_files/METODIKA\%201teorijske\%20osnove/9.\%20PREDAVANJE-

SREDSTVA\%20I\%20POMAGALA/katalog_06_07.pdf (1 October 2008)

MZOŠ (2007). “Katalog odobrenih udžbenika za osnovnu školu 2007-2008”. Ministry of Education, Science and Sport Website. Retrieved from http://public.mzos.hr/fgs.axd?id=12835 (February 1, 2009)

MZOŠ (2007). “Katalog odobrenih udžbenika za strukovne škole 2007-2008”. Ministry of Education, Science and Sport Website. Retrieved from http://public.mzos.hr/fgs.axd?id=12836 (February 1, 2009)

MZOŠ (2007). “Katalog odobrenih udžbenika za gimnazije 2007-2008”. Ministry of Education, Science and Sport Website. Retrieved from http://public.mzos.hr/fgs.axd?id=12837 (February 1, 2009)

Najbar-Agičić, Magdalena (N/A). "Popis obaveznih udzbenika u Republici Hrvatskoj u skolskoj godini 2001./2002. za predmete: Hrvatski jezik, Povijest, Zemljopis”. South-East Europe Textbook Network. Retrieved from www.ffzg.unizg.hr/seetn/states/croatia/udzbenici1.htm (October 1, 2008) 


\section{Appendix B: Critical Discourse Moments in 1991-2007}

\begin{tabular}{lll}
\hline \multicolumn{2}{l}{ Observed periods* in 1991-2007: } & \\
\hline January: & 10th - 21st & (starting from 1992) \\
March: & 16th - 20th & (starting from 1992) \\
April: & 9th - 25th & (starting from 1992) \\
May: & the whole month & (starting from 1992) \\
June: & 22th - 28th & (in 1991: June 25th - July 25th) \\
July: & 26th - 31th & (starting from 1992) \\
August: & 1st - 2nd & \\
September: & 17th - 21st & (in 1999: the whole month) \\
October: & 17th -21 žst & (in 2000: October 23th - 26th) \\
November: & 8th - 12th; 29th - 30th & \\
December: & 1st - 5th; 10th - 14th; 22th & \\
\hline
\end{tabular}

*In the dailies the Večernji list, the Vjesnik and the Novi list the issues for each specified date examined; in the weekly Feral Tribune the issues for the weeks that incorporate specified dates examined.

Yugoslavia and World-War-Two related topics that were used as criteria for the selection of the critical discourse moments:

World War Two, the Partisans, antifascism, the NDH

April 10th Anniversary of Establishment of the NDH

April 22nd

1991-2001: May 5th

May 15h

2000: June 22nd

November 9th
Anniversary of the Jasenovac concentration camp prisoner break-out

Annual demonstrations demanding the return of the name "The Square of the Antifascist Victims" to one of the main capital squares.

Anniversary of surrender of the NDH armed forces: commemoration of victims of Bleiburg and the Way of the Cross

Official Croatian holiday: Day of the Antifascist Struggle

Successful vote on the decision to return the name "The Square of the Antifascist Victims" to one of the main capital squares.

International Day of the Struggle against Fascism and Anti-Semitism

Archbishop Alojzije Stepinac

September 18th Anniversary of arrest of Alojzije Stepinac

October 18th Anniversary of the court ruling in the case of Alojzije Stepinac

Bruno Bušić

September $1991 \quad$ Various events related with the retrieval of Bušić's bodily remains from France to Croatia

Josip Broz Tito

\begin{tabular}{ll}
\hline May 4th & Anniversary of Tito’s death \\
May 25th & Anniversary of Tito’s birthday: former Yugoslav holiday Day of Youth
\end{tabular}

The 1960s/1970s Movements

January 11th Anniversary of arrest of some of the most well-known activists of

Matica hrvatska, country-wide arrests of Matica hrvatska employees 
January 15th-17th

March 17th

April 16th

July 30th

December 1st-2nd

December 11th
Anniversary of the 10th Session of the Communist Party Central Committee of Croatia, followed by a wave of liberalization in Croatia Anniversary of Declaration on the Title and Position of the Croatian Language

Anniversary of breaking of the Novi Sad Agreement and the publication of the first issue of the Hrvatski tjednik

Anniversary of the Supreme Court Decision to ban the distribution of the Hrvatski tjednik

Anniversary of the 21st Session of the Communist Party Central Committee of Croatia, usually interpreted as the end of the Croatian Spring

Anniversary of the collective resignation of the members of the Executive Committee of Matica hrvatska

Proclamation of Independence from Yugoslavia

1991: June 25th - $\quad$ First month after the proclamation of independence from the Socialist July 25th Federal Republic of Yugoslavia

June 25st Anniversary of proclamation of Croatian independnce

Anniversaries of important Yugoslav holidays

May 1st

July 27th

November 29th

December 22nd
The First of May/Labour Day

The Day of the Antifascist Uprising

The Day of the Republic

The Day of the Yugoslav National Army (JNA)

Notes:

1) Period of observation: one day before and three days after the relevant date (five days total). Exceptions are the anniversaries of the Yugoslav holidays where only the relevant date is observed.

2) For series-of-articles featured on the selected dates, the whole series is examined, independently from the dates on which particular issues were published.

\section{Acknowledgements:}

In the choice of the important dates used as the criteria for the critical discourse moments I consulted Prof. Dr. Ivo Goldstein and Dr. Zdenko Radelić. Prof. Dr. Goldstein is a full professor at the History Department at the Faculty of Humanities and Social Sciences at the University of Zagreb, and the author of the book Croatia 1918-2008 (2008). Dr. Radelić is a scientific advisor at the Croatian Institute for History, and the author of the book Croatia in Yugoslavia 19451991: From Togetherness to the Break up (2006). Their advice is gratefully appreciated. 


\section{Appendix C: Meta-frames and Frames on Yugoslavia in History Textbooks, Newspapers and Interviews}

POLITICAL AND ECONOMIC PERSPECTIVES ON YUGOSLAVIA

Meta-frame: Yugoslavia is a Non-Democratic System

- Frame 1 (major, negative evaluation): Non-Democratic System Proper

Frame Attributes:

Explicit Definition of the Regime as Non-Democratic

- Idea Elements: One-party system, totalitarian/dictatorship, military

system (no textbooks), ideological system

Non-Democratic Characteristics of the Regime

- Idea Elements: Limitations of rights and freedoms, dissatisfaction with

non-democratic elements (textbooks only), broken promises about democracy (no interviews), false democratic practices (no newspapers), misuse of power, 1960s/70s movements for democratizing changes (no interviews)

Yugoslav Democratizing Changes Stopped or Failed (no interviews)

- Idea Elements: Democratizing changes stopped or failed, Croatian Spring as failure of democratic transformation, JNA as conservative force, denying democratizing changes of the Constitution 1974

Democratic Individuals and Groups as Positive and v.v. (no interviews)

- Idea Elements: Croats are democratic, Hebrang positive because

democratic, Croatian Spring communist democratic, Tito negative because non-democratic

The 1945 Elections were Non-Democratic

- Idea Elements: Coercion/fear, fraud (no interviews), non-democratic means (no interviews), no choice (textbooks only), communist dominance (no interviews)

[contradicts: Relativization of 1945 Elections (textbooks only)]

- Frame 2 (minor, positive evaluation): Democratizing Changes

- Frame Attributes:

Democratizing Changes Proper (no interviews)

- Idea Elements: After break with the USSR, in the 1950s (textbooks

only), democratic consequences of Self-management, in the 1960s, democratic consequences of the Constitution 1974 (newspapers only)

Meta-frame: Yugoslavia is an Anti-Capitalist System

[contradicts: Self-management/Socialism Better than Capitalism (no textbooks)]

- Frame 1 (major, negative evaluation): Anti-Capitalist System Proper

Frame Attributes:

Non-Capitalistic Characteristics

- Idea Elements: Socialist/Communist order and features, dissatisfaction

with non-capitalistic aspects (no newspapers), denying capitalist

developments (newspapers only), destroying capitalist relations after WW2

(no interviews) capitalists are ideological enemies (textbooks only),

1960s/1970s movements for market changes (no interviews)

[contradicts: Support for post-WW2 changes (newspapers only)] 
Socialist Economy is Inefficient

[contradicts: Some Successful Elements of Yugoslav Economy]

- Idea Elements: Planned economy thwarted development, harmful consequences of socialist economy (no interviews), failed economic reforms because not market enough (newspapers only), inefficient/bureaucratic management, economic emigration due to economic problems, 1980s crisis linked to economic problems, 1980s crisis linked to dissolution (no interviews), 1980s crisis linked to social problems (no interviews), other crises linked to economic problems, consumerist scarcity (no textbooks)

Socialist Economy is Ruled by Party Politics

- Idea Elements: Proclaimed principle different from party practice, political criteria for managers/positions, nepotism/corruption (textbooks only), failed economic reforms due to continued political control over market (no interviews

[contradicts: More accountability/Less corruption or nepotism than today]

Socialist Economy is not Sustainable

- Idea Elements: Economic development linked to credits from the West, market reform necessary because of economic problems (no interviews), artificial economic stability (interviews only), shared problems with other socialist countries in the 1980s (no newspapers)

- Frame 2 (minor, positive evaluation): Capitalist Developments

Frame Attributes:

Capitalist Developments in Yugoslavia Proper

- Idea Elements: Market changes at certain periods (no interviews), freer economic developments after the break with the USSR (no interviews), atypical socialism/development of consumerist or capitalist elements

\section{REPRESSIVENES OF THE SYSTEM}

\section{Meta-frame: Yugoslavia is a Repressive System}

[contradicts: Testimonies of Personal Freedoms in Yugoslavia]

- Frame 1 (major, negative evaluation): Repressive System Proper

Frame Attributes:

Opposition is Not Allowed

- Idea Elements: Opposition/criticism persecuted, opposition into political emigration, cruelty to imprisoned opposition, Goli Otok, labels against opposition (no interviews)

Persecutions and Retributions

- Idea Elements: Executions and camps after WW2, persecutions of groups defeated in WW2 and their families, persecutions of political emigrants, persecutions of the 1960s/1970s movements, persecutions of families of political prisoners (no interviews)

[contradicts: Questioning the degree of persecutions (interviews only)] Repressive Characteristics

- Idea Elements: Police state, atmosphere of fear and surveillance, pressures to join Communist Party (no textbooks), removals in all republics, forced work actions, fraud on West (newspapers only) 
[contradicts: Relativization of Forced Party Membership (interviews only)]

[contradicts: Positive Evaluations of Work Actions (no newspapers)]

Anti-Religious Repression

- Idea Elements: Repression against Catholic Church, repression against

religious communities (no interviews), discrimination of believers, sanctions

against religious functions, propagation of atheism, anti-religious propaganda

and school teaching, goal of destruction of religion and church (textbooks

only)

Legal System Controlled (no interviews)

- Idea Elements: No rule of law, political trials

Censorship

- Idea Elements: Media censored, silence on partisans’ crimes,

autocensure out of fear (no interviews), verbal delict (no interviews)

Internal Disciplining and Purging

- Idea Elements: Internal purges (no interviews), disciplining Informbiro

and Stalin supporters, Informbiro crisis used for dealing with opponents (no

interviews), confusion among Croatian communist during Informbiro crisis

(textbooks only)

- Frame 2 (minor, positive evaluation): Relativization of Repressive Elements

Frame Attributes:

Easing of Oppression in Certain Areas and Periods

- $\quad$ Idea Elements: In media, of religious repression, after break with the

USSR (textbooks only)

Yugoslav System Better in Comparison with Others Such

- Idea Elements: Better than other communist countries, more human

socialism (no textbooks)

ETHNIC PERSPECTIVES ON YUGOSLAVIA

Meta-frame: False Federal Organization

- Frame 1 (major, negative evaluation): Formal Federalism and Centralization

- Frame Attributes:

Explicit Statements of Formal Federalism or Centralization

- Idea Elements: Centralization (no newspapers), by Communist Party, by

capital/Belgrade, broken promise about federal organization (no interviews),

only appearance of autonomy in Croatia (no interviews)

[contradicts: Relativization of Centralization (interviews only)]

Formal Federalism is Unsatisfactory

- Idea Elements: 1960s/1970s movements against centralization/for federal reforms, dissatisfaction with centralist policies (no interviews), necessity of federal changes (no interviews)

Tensions Caused by Formal Federalism

- $\quad$ Idea Elements: Conflicts between federalists and centralists (no

interviews), power struggles between republics, tensions between federal and

republic levels (no interviews)

Opposition to Federal Reforms (no interviews)

- Idea Elements: Opposition to federal reforms, opposition linked to Serbs, 
defeat or denial of federal changes

- Frame 2 (minor, positive evaluation): Federal Reforms (no interviews)

- Frame Attributes:

Federal Changes

- Idea Elements: After break with the USSR (newspapers only), in 1960s, in 1970s, with the 1974 Constitution

Support for Federal Changes

- Idea Elements: Croats (and Slovenes) and non-centralists (textbooks

only), non-Serbian republics supporting federal changes

Meta-frame: Yugoslav Unity Violates National Rights

- Frame 1 (major, negative evaluation): Dominant Politics Violates National Rights

[contradicts: National Rights Better than Before (no interviews)]

Frame Attributes:

National Rights are Suppressed

- Idea Elements: Politics of unitarism/suppression of national identities and rights, dissatisfaction with unitarism (no interviews), national expression is

punished, artificial merger of cultures, 1960s/1970s movements against

unitarism/for national rights

[contradicts: Relativization of Ethnic Oppression (interviews only)]

Dominant Ideology is Anti-National

- $\quad$ Idea Elements: Institutional resistance to national movements (textbooks

only), linked to Serbs (textbooks only), ideology of supranational Yugoslavia,

unitarist labels (no interviews), Serbs using unitarist labels (textbooks only)

- Frame 2 (minor, negative evaluation): National Question is Unsolved

- $\quad$ Frame Attributes:

National Question is Unsolved

- Idea Elements: National question is a problem (no interviews), existence

of ethnic tensions

[contradicts: Relativizating or Questioning Ethnic Tensions (interviews only)]

Meta-frame: National Inequality

- Frame 1 (major, negative evaluation): National Inequality Proper

Frame Attributes:

Existence of National Inequality

- Idea Elements: Existence of national inequality proper, dissatisfaction

with national inequality (no interviews)

1960s/1970s Movements against National Inequality

- Idea Elements: For equality of Croatian language and culture, for more

economic independence, questioning Croatian position, for equality of nations

(no newspapers), for greater republic independence

Unequal Regional Development

- Idea Elements: Unequal regional development proper, Croatian (and

Slovenian) development most developed and thwarted

[contradicts: Developmental Re-Distribution as Good Policy (interviews only)]

[contradicts: Croatian Economy Equal or Better than Others (interviews only)] 
- Frame 2 (major, negative evaluation): National Inequality as Politics of Serbian

Dominance

[contradicts: Questioning Serbian Hegemony (interviews only)]

Frame Attributes:

Unitarism is Politics of Cultural Serbization

- Idea Elements: 1960s/1970s movements against dominance of Serbian

language (no interviews), unitarism is associated with Serbian politics (no interviews), particular suppression of non-Serbian identities, Serbian language is dominant variant, Serbian culture as foundation for Yugoslav culture (no interviews)

Serbian Political and Economic Dominance

- $\quad$ Idea Elements: Serbian hegemony, Serbs in privileged positions, Serbia controls finances and exploits others, Serbian interests served by centralist politics (textbooks only)

- Frame 2 (minor, positive evaluation): National Equality Measures

- $\quad$ Frame Attributes:

Contributions of the 1974 Constitution (no interviews)

Meta-frame: Croatian Victimization

- Frame 1 (major, negative evaluation): Croatian Victimization on National Level

Frame Attributes:

Victimization of Croats as Ethnic Group

- Idea Elements: Croatian identity denied, oppression and retributions against Croatian people, unfair blame for ustasha and denial of antifascism, Yugoslavia was harmful for Croatia, Serbs blamed for Croatian ethnic vicitimization

[contradicts: Relativization of Croatian Oppression in Yugoslavia (interviews only)]

Discrimination against Croats

- Idea Elements: Croats discriminated, Croats discriminated in favor of Serbs (textbooks only), Croats discriminated even if Communist Party members (textbooks only), Croats particularly discriminated if not Communist Party members (no newspapers), Croats gets positions only if identified as Yugoslavs (textbooks only), victimization of Croatian emigrants (no interviews)

Damaging Croatian Republic

- Idea Elements: Croatia exploited, Croatia kept in subordinated position (no textbooks), biological endangerment of Croatia (no interviews), Croatia damaged with Yugoslav economic policy (no interviews), Croatia's interests not represented (textbooks only), Croatia damaged with Yugoslav borders (no interviews)

[contradicts: Questioning Croatian Exploitation (interviews only)]

[contradicts: Croatia as Powerful in Yugoslavia as Other Republics (interviews only)]

- Frame 2 (major, negative evaluation): Croatian Victimization on Individual Level

- $\quad$ Frame Attributes: 
Croatian Communist Hebrang as Victim (no interviews)

- Idea Elements: Fought for Croatian interests, fought against Serbian nationalism, major antifascist contribution

[contradicts: Alternative Perspectives on Hebrang (no interviews)]

Catholic Archbishop Stepinac as Victim

- Idea Elements: Victimized, falsely accused (no interviews), symbol for

Croats (no interviews)

[contradicts: Controversy about Stepinac (no interviews)]

Croatian Emigrant Bušić as Victim (no interviews)

- Idea Elements: Martyr for Croatia, great significance in patriotic

emigrant community

[contradicts: Overemphasizing Bušić’s Significance (newspapers only)]

Meta-frame: Serbian Nationalism as Expansionism

- Frame 1 (negative evaluation): Serbian Nationalism as Expansionism

Frame Attributes:

Serbian Nationalism

- Idea Elements: Associated with Great Serbian nationalism, using "Great

Serbian” casually (no interviews), stems from territorial concerns (no interviews), linked to Yugoslav break-up, growth of Serbian nationalism, aggressive instances of Serbian nationalism (no interviews)

\section{SOCIAL PERSPECTIVE ON YUGOSLAVIA}

\section{Meta-frame: Social Conditions and Advances in Yugoslavia}

- Frame 1 (major, positive evaluation): Good or Better Lives

- $\quad$ Frame Attributes:

Good or Better Lives in Yugoslavia (no textbooks)

- Idea Elements: Good/Better lives proper, affordable amenities, needs

were satisfied, workers'/social rights high/er, more relaxed lives (interviews only)

[contradicts: Problematic Aspects of Good Lives]

[contradicts: Questioning Better Lives or Better Standards Today]

Better Social Relations (no textbooks)

- Idea Elements: Equality among people, greater solidarity/community, more socially just society, better for vulnerable groups

Advancements in Social Measures

- Idea Elements: Advancements in social measures, optimism/faith in

future after WW2

[contradicts: Problematizing Yugoslav Social Measures]

Meta-frame (minor): Social Injustice

- Frame 1 (major, ambiguous /negative evaluation): Land Re-Distribution

Frame Attributes:

Land Re-Distribution Proper

- Idea Elements: Land redistributed, land taken away

- Frame 2 (major, negative evaluation): Unfair Social Relations 


\section{- Frame Attributes:}

Unfair Social Relations

- Idea Elements: Capability unrewarded (no textbooks), unfair treatment of people and their work, privileged groups, life of restraints and collectivism (interviews only)

\section{OTHER MINOR META-FRAMES}

Meta-frame: International Political Independence

- Frame 1 (major, positive evaluation): International Political Independence Proper

[contradicts: Yugoslavia's Negative International Presence (no interviews)]

- $\quad$ Frame Attributes:

Yugoslavia's Oppositional Position to Stalin/USSR

- Idea Elements: Opposition to Stalin, Stalin's attempts at control,

Stalin/Informbiro attack (no interviews), break with the socialist bloc (no

textbooks), turning Yugoslavia to West

Yugoslavia as International Political Player

- Idea Elements: Strong Yugoslav international presence, Yugoslavia as

bridge between West and East, role in non-aligned movement, positive image

abroad, international strength of Yugoslav Communist Party (no interviews)

- Frame 2 (minor, negative evaluation): Anti-Independent Developments

Frame Attributes:

Anti-Independent Developments (no interviews)

- Idea Elements: Close alliance with the USSR after WW2, modeling Yugoslavia on USSR after WW2, Yugoslavia early in conflict tries to prove loyalty to USSR (textbooks only), international opposition to instability in Yugoslavia, negative economic consequences after break with the USSR, help from West sustains opposition to Stalin, West uses Yugoslavia as propaganda tool (newspapers only), later following USSR

\section{Meta-frame: Modernization}

- Frame 1 (positive evaluation): Modernizing Developments

- $\quad$ Frame Attributes:

Modernizing Developments Proper

- Idea Elements: Modernization, industrialization, urbanization (no

newspapers), development of transport infrastructure (no newspapers), tourism, country building (no newspapers), increases in living standards (no newspapers)

[contradicts: Problematic Modernization (no newspapers)]

\section{Meta-frame: Cultural Developments}

- Frame 1 (positive evaluation): Positive Cultural Developments

\section{- Frame Attributes:}

Advances in Culture, Arts, Science (textbooks only)

Link with Western Culture (no newspapers)

- Frame 2 (negative evaluation): Civilizational Lapse Away from Europe

- Frame Attributes: 
Communist Regimes Separates Croatia from European Circle (no interviews)

Civilizational Divide between Western and Eastern Yugoslav Republics (only

newspapers)

Meta-frame: Anti-Communist Resistance

- Frame 1 (negative evaluation): Catholic Church as Site of Resistance

Frame Attributes:

Catholic Church Persecuted as Anti-Communist (no interviews)

- Idea Elements: Persecuted because of its independence (textbooks only), because of its criticism/opposition, because of its influence (textbooks only), because more uncontrollable than other religious communities (textbooks only)

Stepinac Persecuted as Anti-Communist

- Idea Elements: Stepinac is anti-communist (no interviews), persecuted

because refuses to be controlled by communists, because he stands up against communist crimes (no interviews), because respected Catholic leader (no interviews)

- Frame 2 (negative evaluation): Militant Anti-Yugoslav Groups as Sites of Resistance Frame Attributes:

Remnants of Defeated World-War-II Forces (textbooks only)

Failed Yugoslav Insurrections (no interviews)

Militant Emigrant Groups (no interviews)

- Frame 3 (negative evaluation): Non-Acceptance of Yugoslavia

Frame Attributes:

Non-Acceptance of Yugoslavia Proper

- Idea Elements: Majority of Croats dissatisfied (no interviews), peasants' rebellions (textbooks only), Matica hrvatska as opposition (no interviews), emigrants as opposition

Meta-frame: Croatian Catholicism

- Frame 1 (negative evaluation): Weak Form

- Frame Attributes:

Link between Catholicism and Croatian Identity

- Idea Elements: Catholicism as Croatian civilizational heritage, Croatian Catholic saints (textbooks only), Catholic Church influential among Croats (textbooks only) Croats helping Church in Yugoslavia (textbooks only) details on Catholic Church administration and press (textbooks only), missionaries among Croatian emigrants (textbooks only)

- Frame 2 (negative evaluation): Strong Form

- $\quad$ Frame Attributes:

Persecution of Catholic Church because of Link with Croatness

- Idea Elements: Particular persecution of Catholic Church to which all Croats belong (no newspapers), persecution of Catholic Church in order to damage Croats 
TITO

\section{Negative Frames}

- Frame 1: Failings as a Leader

- Idea Elements: Dictator, criminal/responsibility for repression and retributions, hesitant/weak leader (no interviews), political hypocrisy (newspapers only), failed to create Yugoslavia that would survive him (interviews only), insensitivity to some social issues (interviews only), leader with poor advisors or poor implementation (no textbooks)

[contradicts: Bleiburg's non-killing Depeche (newspapers only)]

- Frame 2: Failings as a Man

- $\quad$ Idea Elements: Hedonist, irresponsible womanizer (no textbooks), negative personality traits, creates court (no textbooks)

- Frame 3: Failings as a Croat

- Idea Elements: Acts against Croatian interests, crimes against Croats (no textbooks), negative role in Croatian Spring, supported unitarism

\section{Positive Frames}

- Frame 1: Positive as a Leader

- Idea Elements: Historic significance, masterful politician, man of people and loved by people (no textbooks), contributed to development of country (no textbooks), contributed to self-management (no interviews), contributed to more egalitarian society (no textbooks), contributed to de-centralization (no interviews), contributed to national equality, positive involvement with Croatian Spring , contribution to Non-Aligned Movement, contribution to Croatian state (no newspapers), antifascist contribution (no textbooks)

[contradicts: Counterdiscourse to Tito being loved or man of people (no newspapers] [contradicts: Denial of Tito’s antifascist contribution (no textbooks)]

- Frame 2: Successful Statesman

- Idea Elements: Influential world statesman (no textbooks), makes Yugoslavia relevant political player (no newspapers), internationally respected, independent leader resisting Stalin

- Frame 3: Positive as a Man

- Idea Elements: Positive personality traits, never nepotist/taking from people

(no textbooks), implied brass in letter to Stalin (no newspapers)

- Frame 4: Star/Celebrity (no textbooks)

- $\quad$ Idea Elements: Showman/glamorous life, loved women, romantic figure (newspapers only)

\section{Ambiguous Frames}

- Key Person of Yugoslavia

Idea Elements: Ruler of Yugoslavia, Tito's death stopped the country/mourned (no textbooks), Tito's death as turning point, cult of personality [contradicts: Tito's counter discourse in Yugoslavia (interviews only)] [contradicts: Tito’s death not a turning point (textbooks only)] 
Appendix D: List of Respondents and Their Characteristics

\begin{tabular}{|c|c|c|c|c|c|}
\hline Pseudonym & Generation & Education & Gender & Region & Class \\
\hline Ante & transitional & college & male & S Croatia & intermediate \\
\hline Anton & transitional & vocational & male & S Croatia & salariat \\
\hline Antun & transitional & vocational & male & S Croatia & working \\
\hline Blizanka & transitional & vocational & female & NW Croatia \& N Coast & working \\
\hline Bruno & transitional & vocational & male & NW Croatia \& N Coast & intermediate \\
\hline Bubo & transitional & college & female & NW Croatia \& N Coast & salariat \\
\hline Cvilim & transitional & college & male & CE and E Croatia & intermediate \\
\hline Darko & transitional & vocational & male & NW Croatia \& N Coast & working \\
\hline Djuro & transitional & college & male & NW Croatia \& N Coast & intermediate \\
\hline Dzeri & transitional & college & male & S Croatia & intermediate \\
\hline Elizabeta & transitional & vocational & female & CE and E Croatia & intermediate \\
\hline Frederica & transitional & college & female & NW Croatia \& N Coast & salariat \\
\hline Hana & transitional & vocational & female & NW Croatia \& N Coast & intermediate \\
\hline Humito & transitional & college & male & CE and E Croatia & salariat \\
\hline Iva & transitional & vocational & female & CE and E Croatia & working \\
\hline Jana & transitional & college & female & S Croatia & working \\
\hline Karlitos & transitional & college & male & CE and E Croatia & salariat \\
\hline Lovro & transitional & vocational & male & S Croatia & working \\
\hline Marija & transitional & college & female & CE and E Croatia & intermediate \\
\hline Marijana & transitional & vocational & female & CE and E Croatia & intermediate \\
\hline Maris & transitional & college & female & CE and E Croatia & salariat \\
\hline Markos & transitional & vocational & male & S Croatia & salariat \\
\hline Max & transitional & college & male & S Croatia & salariat \\
\hline Melita & transitional & vocational & female & CE and E Croatia & intermediate \\
\hline Merkur & transitional & college & female & S Croatia & intermediate \\
\hline Perica & transitional & vocational & male & NW Croatia \& N Coast & working \\
\hline Pero & transitional & college & male & NW Croatia \& N Coast & working \\
\hline Petar & transitional & vocational & male & NW Croatia \& N Coast & working \\
\hline Picard & transitional & college & male & NW Croatia \& N Coast & salariat \\
\hline Sana & transitional & vocational & female & $\mathrm{CE}$ and E Croatia & working \\
\hline Sanja & transitional & college & female & NW Croatia \& N Coast & salariat \\
\hline Stjepan & transitional & vocational & male & S Croatia & intermediate \\
\hline Tea & transitional & vocational & female & CE and E Croatia & intermediate \\
\hline Tena & transitional & college & female & S Croatia & working \\
\hline Zoran & transitional & vocational & male & S Croatia & intermediate \\
\hline Zvijezda & transitional & college & female & CE and E Croatia & working \\
\hline Alan & post-communist & college & male & NW Croatia \& N Coast & salariat \\
\hline Amanda & post-communist & vocational & female & NW Croatia \& N Coast & salariat \\
\hline Aparat & post-communist & college & male & NW Croatia \& N Coast & working \\
\hline Barbara & post-communist & vocational & female & S Croatia & working \\
\hline
\end{tabular}




\begin{tabular}{|c|c|c|c|c|c|}
\hline Danko & post-communist & vocational & male & S Croatia & intermediate \\
\hline Djurdjica & post-communist & vocational & female & NW Croatia \& N Coast & working \\
\hline Dorian & post-communist & vocational & male & NW Croatia \& N Coast & working \\
\hline Draven & post-communist & college & female & S Croatia & salariat \\
\hline Ela & post-communist & college & female & CE and E Croatia & salariat \\
\hline Emerika & post-communist & vocational & female & CE and E Croatia & salariat \\
\hline Fumarole & post-communist & college & male & NW Croatia \& N Coast & intermediate \\
\hline Ivan & post-communist & vocational & male & CE and E Croatia & intermediate \\
\hline Ivana & post-communist & college & female & S Croatia & working \\
\hline Ivica & post-communist & vocational & male & NW Croatia \& N Coast & salariat \\
\hline Janko & post-communist & vocational & male & CE and E Croatia & salariat \\
\hline Joshua & post-communist & college & male & S Croatia & intermediate \\
\hline Josip & post-communist & vocational & male & CE and E Croatia & working \\
\hline Lax & post-communist & vocational & male & NW Croatia \& N Coast & working \\
\hline Lidija & post-communist & vocational & female & CE and E Croatia & intermediate \\
\hline Lili & post-communist & college & female & S Croatia & salariat \\
\hline Luka & post-communist & college & male & $\mathrm{CE}$ and $\mathrm{E} \mathrm{Cr}$ & salariat \\
\hline Mala & ommunist & vocational & female & S Croatia & working \\
\hline Mario & post-communist & vocational & male & S Croatia & working \\
\hline Marko & post-communist & vocational & male & CE and E Croatia & salariat \\
\hline Mirko & post-communist & college & male & CE and E Croatia & working \\
\hline Puki & post-communist & vocational & male & S Croatia & working \\
\hline Rina & post-communist & college & female & S Croatia & salariat \\
\hline Samuel & post-communist & college & male & NW Croatia \& N Coast & intermediate \\
\hline Srecko & post-communist & vocational & male & S Croatia & salariat \\
\hline Tihomir & post-communist & college & male & CE and E Croatia & intermediate \\
\hline Tina & post-communist & vocational & female & NW Croatia \& N Coast & salariat \\
\hline Tomislav & post-communist & college & male & NW Croatia \& N Coast & salariat \\
\hline Vanesa & post-communist & college & female & CE and E Croatia & salariat \\
\hline Vjesalica & post-communist & college & female & NW Croatia \& N Coast & salariat \\
\hline Zadranin & post-communist & college & male & S Croatia & salariat \\
\hline Zlatka & post-communist & college & female & CE and E Croatia & salariat \\
\hline
\end{tabular}




\section{Appendix E: Interview Guide}

Questionnaire (filled in before the interview):

Code: Pseudonym:

1. Birth Year:

2. Education:

3. Occupation:

4. County in which most of the childhood \& adolescence was spent:

5. During the war, have you or your family experienced displacement? _ yes _ _ no

6. If yes and if different from 4), what is the county where you lived before displacement?

7. Father's occupation:

8. Mother's occupation:

Interview Guide:

Presentation to Foreigners

Have you ever had a chance to take a foreigner around Croatia?

- Where did you take him/her? How come?

What did you tell him/her about Croatian history or culture? What did you tell him/her about Yugoslavia?

if neither of above: Let's say you have an acquaintance from Island, who knows nothing about Croatia, coming to visit you. Where would you take him/her? (matching gender with

interviewee's gender)

What would you show to him/her?

What would you tell him/her about Croatia?

What would you tell him/her about Croatian history or culture? How come?

What did you tell him/her about Yugoslavia?

Or: Say, this person did not know anything about Yugoslavia, what would you tell him/her, what kind of state was Yugoslavia?

What things come to your mind when you are thinking about the aspects of Croatian culture or history that make you proud? How come?

What things come to your mind when you are thinking about the aspects of Croatian culture or history that make you ashamed? How come?

"Croatness"

Which groups come to your mind when you are thinking about groups similar to Croats? How come?

Some say Croatia is a Balkan country. What do you think about it? How come?

What "Balkan" means to you?

What do you think, how important is Catholicism for Croatian culture? How come?

Life in Yugoslavia (*questions not applicable to the post-communist generation)

When you are thinking about your early childhood, what are your best or fondest memories?* And what are your worse memories?*

Is there a memory from your early childhood that you think is typical for your generation, that children born after the break-up of Yugoslavia could not have experienced?*

Could you describe to me how you have become a pioneer?*

Do you remember any of the Yugoslav celebrations?* Could you describe them for me?

Have you ever gone shopping outside Yugoslavia? Could you describe one of these trips to me? 
Did you, as a child, role-play partisans?* Can you describe these games to me?

Before the war, were there any pupils of different nationalities or religions in your class?*

- $\quad$ Were you aware of the difference? How come?

- $\quad$ If not: Do you remember when you became aware of the difference?

Do you remember what you learned about Yugoslavia in school?

Which textbook stories of Tito do you remember? Do you remember stories about Tito from some other sources (TV, older people..)? Can you tell me these stories?

Have you ever gone to visit Tito's birthplace, Tito's mausoleum, Brioni or something similar?

Can you describe this visit to me?

What do you think about Tito?

Have your parents or family members ever told you what it was like living in Yugoslavia for them? Could you tell me their stories?

What about the teachers? No matter what they taught, have they ever spoke how it was like living in Yugoslavia for them? Could you tell me their stories?

Do you remember any old Yugoslav movies or TV shows?* Could you describe to me what you remember from these movies or shows?*

- What do you think, what was the impression of Yugoslavia you got form these movies or shows?*

Have you watched any newer Croatian movies or TV shows about Yugoslav period? Could you describe to me what you remember from these movies or shows?

What do you think, how is Yugoslavia differently presented today?

What do you think, how media today are portraying Yugoslavia?

What it comes to your mind about "brotherhood and unity"?

What do you think, what Croatia's political or economic position in Yugoslavia was like? What images or things come to your mind?

- Where did you got these stories or images? Did you learn about it, read about it, heard about it?

What do you think, what does your generation or your peers think about Yugoslavia? How come?

Do you think there is such a thing as Yugo-nostalgia? What would that be? Who are people who are yugo-nostalgic?

Are there some specific groups of people who lived better in Yugoslavia than they are living today? How come?

Croatia today: communism VS capitalism

What was good in Yugoslav communism or socialism? How come?

What was bad in Yugoslav communism or socialism? How come?

How about Croatian capitalism? What is good about it? What is bad about it? How come?

What do you think, do the remnants of the old system in any way influence how the Croatian society functions today?

Do you think about leaving Croatia and living elsewhere? How come?

Images - Lexicon of Yu Mythology

List of images: 1) Yugoslav hymn; 2) Death to Fascism, Freedom to People; 3) May Parade; 4)

Work Actions; 5) Pioneer; 6) Flower for Tito; 7) Tito’s Death

Could you, please, browse through these photographs and just think aloud about them? Just tell me anything that comes to you mind.

- $\quad$ Have any of your family members, parents, teacher ever talked about that? 
Topics that were introduced earlier in the interview if appropriate or at the end of the interview, if not mentioned before

Could you describe to me the differences in life of your family in Yugoslavia and after the transition? Have their standards changed and how?

Could you describe to me your earliest memories about the war? (transitional generation) Do you have any memories about the war? Could you describe them to me? (post-communist generation)

Could you describe to me what happened with your family during the war?

Concluding question

We've been talking about this the whole time. So, now in the end, what would you say, what's your opinion about Yugoslavia? 


\section{REFERENCES}

Alasuutari, Pertti. (1999). “Introduction. Three Phases of Reception Studies.” Pp. 1-21 in Rethinking the Media Audience: the New Agenda, edited by P. Alasuutari. London: Sage.

Apple, Michael W. (2000). Official Knowledge: Democratic Education in a Conservative Age. New York/London: Routledge.

- (2003). The State and the Politics of Knowledge. New York/London: Routledge.

Armstrong, Elizabeth A. and Suzanna M. Crage. (2006). "Movements and Memory: The Making of the Stonewall Myth.” American Sociological Review 71:724-751.

Armstrong, Elizabeth A. and Martin S. Weinberg. (2006). "Identity and Competence: The Use of Culture in The Interpretation of Sexual Images.” Sociological Perspectives 49:411-432.

Assmann, Jan. (1995). “Collective Memory and Cultural Identity.” New German Critique:125133.

World Bank. (2012). “World Development Indicators Online (WDI) Database.” Retrieved October 15, 2012 (http://data.worldbank.org/data-catalog/world-development-indicators).

Beamish, Thomas D., Harvey Molotch, and Richard Flacks. (1995). "Who Supports the Troops? Vietnam, the Gulf War, and the Making of Collective Memory.” Social Problems 42:344-360.

Beattie, Andrew H. (2011). "The Politics of Remembering the GDR: Official and StateMandated Memory since 1990.” Pp. 23-34 in Remembering the German Democratic Republic: Divided Memory in a United Germany, edited by D. Clarke and U. Wölfel. Basingstoke: Palgrave Macmillan.

Beim, Aaron. (2007). “The Cognitive Aspects of Collective Memory.” Symbolic Interaction 30:7-26.

Bellamy, Alex J. (2003). The Formation of Croatian National identity: A Centuries-Old Dream. Manchester: Manchester University Press.

Bodnar, John. (1992). Remaking America: Public Memory, Commemoration, and Patriotism in the Twentieth Century. Princeton, NJ: Princeton University Press.

Bratich, Jack. (2008). “Activating the Multitude: Audience Power and Cultural Studies.” Pp. 3356 in New Directions in American Reception Study, edited by P. Goldstein and J. L. Machor. Oxford: Oxford University Press.

Brekhus, Wayne. (2007). “The Rutgers School. A Zerubavelian Culturalist Cognitive Sociology.” European Journal of Social Theory 10:448-464.

Bromberg, Minna and Gary Alan Fine. (2002). "Resurrecting the Red: Pete Seeger and the Purification of Difficult Reputations.” Social Forces 80:1135-1155.

Brown-Saracino, Japonica and Armin Ghaziani. (2009). "The Constraints of Culture: Evidence from the Chicago Dyke March.” Cultural Sociology 3:51-75.

Cast, Alicia D. and Peter J. Burke. (2002). “A Theory of Self-Esteem.” Social Forces 80:10411068.

Cerulo, Karen A. (1997). “Identity Construction: New Issues, New Directions.” Annual Review of Sociology 23:385-409.

-. (2002). "Establishing a Sociology of Culture and Cognition." Pp. 1-12 in Culture in Mind: Toward a Sociology of Culture and Cognition, edited by K. A. Cerulo. New York: Routledge.

Chilton, Paul. (1987). "Metaphor, Euphemism and the Militarization of Language.” Current Research on Peace and Violence 10:7-19. 
Clarke, David and Ute Wölfel. (2011). "Remembering the German Democratic Republic in a United Germany." Pp. 3-22 in Remembering the German Democratic Republic: Divided Memory in a United Germany, edited by D. Clarke and U. Wölfel. Basingstoke: Palgrave Macmillan.

Confino, Alon. (1997). "Collective Memory and Cultural History: Problems of Method.” The American Historical Review 102:1386-1403.

Conway, Martin A. (1997). “The Inventory of Experience: Memory and Identity.” Pp. 21-46 in Collective Memory of Political Events: Social Psychological Perspectives, edited by J. W. Pennebaker, D. Páez, and B. Rimé. Mahwah, NJ: Erlbaum Associates.

Coser, Lewis A. (1992). "The Revival of the Sociology of Culture: The Case of Collective Memory.” Sociological Forum 7:365-373.

Cramer Walsh, Katherine. (2004). Talking about Politics: Informal Groups and Social Identity in American Life. Chicago: University of Chicago Press.

Crane, Susan A. (1997). "Writing the Individual Back into Collective Memory.” American Historical Review 102:1372.

Creswell, John W. (2007). Qualitative Inquiry and Research Design: Choosing Among Five Approaches (2nd Edition). London \& Thousands Oaks, CA: Sage.

Cunningham, David, Colleen Nugent, and Caitlin Slodden. (2010). "The Durability of Collective Memory: Reconciling the "Greensboro Massacre”." Social Forces 88:1517-1542.

Dierkes, Julian. (2010). Postwar History Education in Japan and the Germanys: Guilty Lessons. New York: Routledge.

DiMaggio, Paul. (1997). “Culture and Cognition.” Annual Review of Sociology 23:263-287.

Ducharme, Lori J. and Gary Alan Fine. (1995). "The Construction of Nonpersonhood and Demonization: Commemorating the Traitorous Reputation of Benedict Arnold.” Social Forces 73:1309-1331.

Edy, Jill A. (1999). “Journalistic Uses of Collective Memory.” Journal of Communication 49:7185.

-. (2006). Troubled Pasts: News and the Collective Memory of Social Unrest. Philadelphia: Temple University Press.

Entman, Robert M. (1993). “Framing: Toward Clarification of a Fractured Paradigm.” Journal of Communication 43.

Erll, Astrid. (2008). "Cultural Memory Studies: An Introduction.” Pp. 1-15 in Cultural Memory Studies: An International and Interdisciplinary Handbook, edited by A. Erll, A. Nünning, and S. B. Young. Berlin/New York: de Gruyter.

Evans, Richard J. (2003). “Redesigning the Past: History in Political Transitions.” Journal of Contemporary History 38:5-12.

Fentress, James and Chris Wickham. (1992). Social Memory. Cambridge: Blackwell

Ferree, Myra M., William A. Gamson, Jürgen Gerhards, and Dieter Rucht. (2002). Shaping Abortion Discourse: Democracy and the Public Sphere in Germany and the United States. Cambridge, MA: Cambridge University Press.

Fine, Gary Alan. (1996). "Reputational Entrepreneurs and the Memory of Incompetence: Melting Supporters, Partisan Warriors, and Images of President Harding.” American Journal of Sociology 101:1159-1193.

Fine, Gary Alan and Aaron Beim. (2007). "Introduction: Interactionist Approaches to Collective Memory.” Symbolic Interaction 30:1-5. 
Flyvbjerg, Bent. (2004). “Five Misunderstandings about Case-Study Research.” Pp. 420-434 in Qualitative Research Practice, edited by C. Seale, G. Gobo, J. Gubrium, and D. Silverman. London: Sage.

Fukuoka, Kazuya. (2011). "School History Textbooks and Historical Memories in Japan: A Study of Reception.” International Journal of Politics, Culture, and Society:1-21.

Gamson, William A. (1992). Talking Politics. Cambridge, MA: Cambridge University Press.

Gamson, William A. and Andre Modigliani. (1989). "Media Discourse and Public Opinion on Nuclear Power: A Constructionist Approach.” The American Journal of Sociology 95:137.

Gamson, William A. and David Stuart. (1992). “Media Discourse as a Symbolic Contest: The Bomb in Political Cartoons.” Sociological Forum 7:55-86.

Garfinkel, Harold. (1964). "Studies of the Routine Grounds of Everyday Activities." Social Problems 11:225-250.

Gillis, John R. (1994). “Memory and Identity: The History of a Relationship.” Pp. 3-24 in Commemorations: The Politics of National Identity. Princeton: Princeton University Press.

Glaser, Barney G. and Anselm L. Strauss. (1967). The Discovery of Grounded Theory: Strategies for Qualitative Research. Chicago: Aldine.

Gobo, Giampietro. (2008a). Doing Ethnography. London: Sage.

—. (2008b). "Re-Conceptualizing Generalization: Old issues in a New Frame.” Pp. 193-213 in The SAGE Handbook of Social Research Methods, edited by P. Alasuutari, L. Bickman, and J. Brannen. London: Sage.

Goldstein, Ivo. (2001). "O udžbenicima povijesti u Hrvatskoj [On History Textbooks in Croatia].” Pp. 15-28 in Dijalog povjesničara-istoričara, vol. 3, edited by H.-G. Fleck and I. Graovac. Zagreb: Zaklada Friedrich Ebert i Zajednica izdavača Dijalog.

—. (2008). Hrvatska 1918-2008 [Croatia 1918-2008]. Zagreb: EPH-Novi Liber.

Goldstein, Philip and James L. Machor. (2008). "Introduction: Reception Study: Achievements and New Directions.” Pp. xi-xxviii in New Directions in American Reception Study, edited by P. Goldstein and J. L. Machor. Oxford: Oxford University Press.

Gray, Ann. (1999). "Audience and Reception Research in Retrospect: The Trouble with Audiences.” Pp. 22-37 in Rethinking the Media Audience: the New Agenda, edited by P. Alasuutari. London: Sage.

Griffin, Larry J. (2004). “"Generations and Collective Memory" Revisited: Race, Region, and Memory of Civil Rights.” American Sociological Review 69:544-557.

Griswold, Wendy. (1987a). "The Fabrication of Meaning: Literary Interpretation in the United States, Great Britain, and the West Indies.” American Journal of Sociology 92:1077.

—. (1987b). “A Methodological Framework for the Sociology of Culture.” Sociological Methodology 17:1-35.

—. (1993). "Recent Moves in the Sociology of Literature.” Annual Review of Sociology:455-467.

- (1994). "Culture and the Cultural Diamond." in Cultures and Society in a Changing World: Thousand Oaks: Pine Forge Press.

Griswold, Wendy, Elizabeth Lenaghan, and Michelle Naffziger. (2011). "Readers as Audiences.” Pp. 17-40 in The Handbook of Media Audiences, edited by V. Nightingale: WilleyBlackwell.

Halbwachs, Maurice. (1992 [1952]). On Collective Memory. Translated by L. A. Coser. Chicago: University of Chicago Press. 
Hamilton, Paula and Linda Shopes. (2008). "Introduction: Building Partnerships between Oral History and Memory Studies.” Pp. vii-xvii in Oral History and Public Memories, edited by P. Hamilton and L. Shopes. Philadelphia: Temple University Press.

Hammersley, Martyn. (1992). What's Wrong with Ethnography?: Methodological Explorations. London/New York: Routledge.

Hammersley, Martyn and Paul Atkinson. (2007). Ethnography: Principles in Practice (3rd Edition). London: Taylor \& Francis.

Hina. (2011). "Mala zemlja sa 116 političkih stranaka [Small Country with 116 Political Parties].” Nacional,November 01, 2011, Retrieved October 15, 2012 (http://www.nacional.hr/clanak/118974/mala-zemlja-sa-116-politickih-stranaka).

Hirst, William and Gerald Echterhoff. (2008). "Creating Shared Memories in Conversation: Toward a Psychology of Collective Memory.” Social Research 75:183-216.

Hobsbawm, Eric J. and Terence O. Ranger. (1992). The Invention of Tradition. Cambridge: Cambridge University Press.

Höpken, Wolfgang. (1997). "History Education and Yugoslav (Dis-)Integration.” Pp. 79-104 in State-Society Relations in Yugoslavia, 1945-1992, edited by M. Bokovoy, J. Irvine, and C. Lilly: Palgrave Macmillan.

- (2007). "Between Civic Identity and Nationalism. History Textbooks in East-Central and Southeastern Europe.” Pp. 163-192 in Democratic Transition in Croatia: Value Transformation, Education \& Media, edited by S. P. Ramet and D. Matić. TAMU, College Station Texas: Texas A\&M University Press.

Freedom House. (2002). “Freedom of the Press 2002 - Croatia.” Retrieved March 15, 2010 (http://www.freedomhouse.org/template.cfm?page $=251 \&$ year=2002).

Freedom House. (2004). “Freedom of the Press 2004 - Croatia.” Retrieved March 15, 2010 (http://www.freedomhouse.org/template.cfm?page $=251$ \&year=2004).

Hyland, Claire. (2011). “The Era Has Passed, But It’s Nice to Remember”: Eastern Identifications with the GDR Past and Unified Germany.” Pp. 144-156 in Remembering the German Democratic Republic: Divided Memory in a United Germany, edited by D. Clarke and U. Wölfel. Basingstoke: Palgrave Macmillan.

Inglehart, Ronald. (2000). “Globalization and Postmodern Values.” Washington Quarterly 23:215-228.

Irwin-Zarecka, Iwona. (1994). Frames of Remembrance: The Dynamics of Collective Memory. New Brunswick, NJ: Transaction Publishers.

Jennings, M. Kent. (1996). "Political Knowledge Over Time and Across Generations.” The Public Opinion Quarterly 60:228-252.

Jurišin, Pero. (2002). "Media Ownership Structure in Croatia: Huge Power of the Media.” Southeast European Media Journal. Retrieved April 01, 2010 (http://www.mediaonline.ba/en/?ID=210).

Kansteiner, Wulf. (2002). "Finding Meaning in Memory: A Methodological Critique of Collective Memory Studies.” History and Theory 41:179.

Kim, Mikyoung and Barry Schwartz. (2010). "Introduction: Northeast Asia's Memory Problem." Pp. 1-27 in Northeast Asia's Difficult Past: Essays in Collective Memory, edited by M. Kim and B. Schwartz. New York: Palgrave Macmillan.

Kitch, Carolyn. (2008). "Placing Journalism Inside Memory - and Memory Studies.” Memory Studies 1:311-320. 
Klein, Kerwin L. (2000). “On the Emergence of Memory in Historical Discourse.” Representations:127-150.

Koren, Snježana. (2003). "Promjene u nastavnom planu i programu za osnovne škole u Republici Hrvatskoj tijekom posljednjeg desetljeća [Changes in the Primary Schools Curriculum in the Republic of Croatia in the Last Decade].” Povijest u nastavi 1:155-163.

—. (2005). "Jugoslavija: pogled u razbijeno ogledalo: tko je "onaj drugi"? [Yugoslavia: a Look in the Broken Mirror. Who is the "Other"?]." Pp. 79-89 in Klio na Balkanu : usmjerenja i pristupi u nastavi povijesti, edited by C. Koulouri. Zagreb: Srednja Europa.

—. (2007). "Slike nacionalne povijesti u hrvatskim udzbenicima uoci i nakon raspada Jugoslavije [Images of the National History in the Croatian History Textbooks on the Eve and after the Yugoslav Break-Up].” Historijski zbornik 60:247-296.

Koren, Snježana and Branislava Baranović. (2009). "What Kind of History Education Do We Have after Eighteen Years of Democracy in Croatia? Transition, Intervention, and History Education Politics (1990-2008).” Pp. 91-140 in "Transition" and the Politics of History Education in Southeast Europe edited by A. Dimou. Gottingen: V\&E unipress.

Lahire, Bernard. (2010). The Plural Actor. Cambridge: Polity.

Lang, Kurt and Gladys Engel Lang. (1989). "Collective Memory and the News.” Communication 11:123-139.

Lang, Kurt, Gladys Engel Lang, Hans-Mathias Kepplinger, and Simone Ehmig. (1993). "Collective Memory and Political Generations: A Survey of German Journalists." Political Communication 10:211-229.

Larson, Jeff A. and Omar Lizardo. (2007). "Generations, Identities, and the Collective Memory of Che Guevara.” Sociological Forum 22:425-451.

Lehmann, René. (2011). “Generation and Transition: East German Memory Cultures.” Pp. 102115 in Remembering the German Democratic Republic: Divided Memory in a United Germany, edited by D. Clarke and U. Wölfel. Basingstoke: Palgrave Macmillan.

Liebes, Tamar and Elihu Katz. (1993). The Export of Meaning: Cross-Cultural Readings of Dallas. Cambridge: Polity Press.

Linde, Charlotte. (2009). Working the Past: Narrative and Institutional Memory. New York: Oxford University Press.

Lindlof, Thomas R. and Bryan C. Taylor. (2002). Qualitative Communication Research Methods. London: Sage.

Malović, Stjepan. (2004). “Croatia.” Pp. 119-140 in Media Ownership and Its Impact on Media Independence and Pluralism., edited by B. Petković. Ljubljana: Peace Institute and Institute for Contemporary Social and Political Studies.

Malović, Stjepan and Gary W Selnow. (2001). The People, Press, and Politics of Croatia. London: Praeger Publishers.

Mannheim, Karl. (1952). “The Problem of Generations.” Pp. 276-320 in Essays on the Sociology of Knowledge. New York: Oxford University Press.

McCombs, Maxwell and Salma I. Ghanem. (2001). "The Convergence of Agenda Setting and Framing.” Pp. 67-81 in Framing Public Life: Perspectives on Media and Our Understanding of the Social World, edited by S. D. Reese, O. H. Gandy Jr., and A. E. Grant. Mahwah, NJ/London: Lawrence Erlbaum Associates.

Mead, George H. (1934). Mind, Self, and Society. Chicago University of Chicago Press.

Middleton, David and Derek Edwards. (1990). "Conversational Remembering.” Pp. 23-45 in Collective Remembering, edited by D. Middleton and D. Edwards. London: Sage. 
Milardović, Anđelko. (2007). “Elite Groups in the Wave of Democratization and Lustration.” Pp. 85-110 in Lustration and Consolidation of Democracy and the Rule of Law in Central and Eastern Europe, vol. 5, edited by A. Milardović. Zagreb: Political Research Science Centre Zagreb.

Misztal, Barbara A. (2003a). "Durkheim on Collective Memory.” Journal of Classical Sociology 3:123-143.

- (2003b). Theories of Social Remembering. Philadelphia, PA: Open University Press.

Najbar-Agičić, Magdalena. (2006). "Od kulta ličnosti do detitoizacije [From Cult of Personality to De-Titoization].” Pp. 377-398 in O Titu kao Mitu. Proslava Dana Mladosti u Kumrovcu., edited by N. Š. Alempijević and K. M. Hjemdahl. Zagreb: FF Press \& Srednja Europa.

Najbar-Agičić, Magdalena and Damir Agičić. (2007). “The Use and Misuse of History Teaching in 1990s Croatia.” Pp. 193-223 in Democratic Transition in Croatia. Value Transformation, Education and Media., edited by S. P. Ramet and D. Matić. TAMU, College Station Texas: Texas A\&M University Press.

Neiger, Motti, Oren Meyers, and Eyal Zandberg. (2011). “On Media Memory: Editors' Introduction.” Pp. 1-24 in On Media Memory: Collective Memory in a New Media age, edited by M. Neiger, O. Meyers, and E. Zandberg.

Neuendorf, Kimberly A. (2001). The Content Analysis Guidebook. Thousand Oaks, CA: Sage. Nora, Pierre. (1989). “Between Memory and History: Les lieux de mémoire.” Representations:724.

—. (1992). "The Era of Commemoration.” Pp. 609-637 in Realms of Memory: Symbols, vol. 3, edited by P. Nora and L. D. Kritzman. New York: Columbia University Press.

—. (1996a). "General Introduction: Between Memory and History.” Pp. 1-20 in Realms of Memory: Rethinking the French Past, vol. 1, edited by P. Nora. New York: Columbia University Pess.

—. (1996b). "Realms of Memory.” Pp. 1-20. New York: Columbia University Press.

Olick, Jeffrey K. (1999). “Collective Memory: The Two Cultures.” Sociological Theory 17:333348.

—. (2003a). “Introduction.” Pp. 1-16 in States of Memory: Continuities, Conflicts, and Transformations in National Retrospection, edited by J. K. Olick. Durham/London: Duke University Press.

- (2003b). "What Does it Mean to Normalize the Past?: Official Memory in German Politics since 1989.” Pp. 259-288 in States of Memory: Continuities, Conflicts, and Transformations in National Retrospection, edited by J. K. Olick. Durham/London: Duke University Press.

—. (2007). "Collective Memory and Nonpublic Opinion: A Historical Note on a Methodological Controversy about a Political Problem.” Symbolic Interaction 30:41-55.

- (2008). "From Collective Memory to the Sociology of Mnemonic Practices and Products." Pp. 151-162 in Cultural Memory Studies: An International and Interdisciplinary Handbook, edited by A. Erll, A. Nünning, and S. B. Young. Berlin/New York: de Gruyter.

Olick, Jeffrey K. and Daniel Levy. (1997). “Collective Memory and Cultural Constraint: Holocaust Myth and Rationality in German Politics.” American Sociological Review 62:921-936. 
Olick, Jeffrey K. and Joyce Robbins. (1998). "Social Memory Studies: From" Collective Memory" to the Historical Sociology of Mnemonic Practices." Annual Review of Sociology 24:105-140.

Olick, Jeffrey K., Vered Vinitzky-Seroussi, and Daniel Levy. (2011). “Introduction.” Pp. 3-62 in The Collective Memory Reader, edited by J. K. Olick, V. Vinitzky-Seroussi, and D. Levy. Oxford: Oxford University.

Ottaway, Marina. (2003). Democracy Challenged: The Rise of Semi-Authoritarianism. Washington: Carnegie Endowment for International Peace.

Croatian Parliament. (2006). "Izvješće o stanju u društvima Vjesnik d.d. i Vjesnik-Naklada [Report on Situation in Vjesnik d.d. and Vjesnik-Naklada].” Retrieved April 29, 2010 (www.sabor.hr/fgs.axd?id=4195).

Pennebaker, James W. and Becky L. Banasik. (1997). "On the Creation and Maintenance of Collective Memories: History as Social Psychology.” Pp. 3-20 in Collective Memory of Political Events. Social Psychological Perspectives, edited by J. W. Pennebaker, D. Páez, and B. Rimé. Mahwah, NJ: Erlbaum Associates.

Perrin, Andrew J. (2006). Citizen Speak: The Democratic Imagination in American life. Chicago: University of Chicago Press.

Pilcher, Jane. (1994). "Mannheim's Sociology of Generations: An Undervalued Legacy.” British Journal of Sociology 45:481-495.

Podeh, Elie. (2000). "History and Memory in the Israeli Educational System: The Portrayal of the Arab-Israeli Conflict in History Textbooks (1948-2000).” History \& Memory 12:65100.

Polletta, Francesca. (2003). "Legacies and Liabilities of an Insurgent Past: Remembering Martin Luther King Jr. on the House and Senate Floor.” Pp. 193-226 in States of Memory: Continuities, Conflicts, and Transformations in National Retrospection, edited by J. K. Olick. Durham/London: Duke University Press.

Popular Memory Group. (2011 [1982]). “Popular Memory: Theory, Politics, Method.” Pp. 254260 in The Collective Memory Reader, edited by J. K. Olick, V. Vinitzky-Seroussi, and D. Levy. Oxford: Oxford University Press.

Press, Andrea L. (1994). "The Sociology of Cultural Reception: Notes Toward an Emerging Paradigm.” Pp. 221-245 in The Sociology of Culture: Emerging Theoretical Perspectives., edited by D. Crane. Oxford: Blackwell.

Radway, Janice A. (1984). "Interpretive Communities and Variable Literacies: The Functions of Romance Reading.” Daedalus 113:49-73.

—. (2008). "What's the Matter with Reception Study? Some Thoughts on the Disciplinary Origins, Conceptual Constraints, and Persistent Viability of a Paradigm.” Pp. 327-352 in New Directions in American Reception Study, edited by P. Goldstein and J. L. Machor. New York: Oxford University Press.

Rajković, Marijeta. (2006). "Uspon i pad jednog političkog mjesta iz perspektive lokalnog stanovništva [Rise and Fall of a Political Site from the Perspective of the Local Inhabitants].” in O Tito kao Mitu, edited by N. Škrbić Alempijević and K. Mathiesen Hjemdahl. Zagreb: FF Press.

Ramet, Sabrina P. (2006). The Three Yugoslavias: State-building and Legitimation, 1918-2005: Indiana University Press; Woodrow Wilson Center Press.

Razsa, M. and N. Lindstrom. (2004). "Balkan Is Beautiful: Balkanism in the Political Discourse of Tudjman's Croatia.” East European Politics and Societies 18:628-650. 
Reese, Elaine and Robyn Fivush. (2008). "The Development of Collective Remembering.” Memory 16:201-212.

Rizzo, Thomas A., William A. Corsaro, and John E. Bates. (1992). "Ethnographic Methods and Interpretive Analysis: Expanding the Methodological Options of Psychologists." Developmental Review 12:101-123.

Rose, David and Eric Harrison. (2007). "The European Socio-Economic Classification: A New Social Class Schema for Comparative European Research.” European Societies 9:459490.

Schudson, Michael. (1989a). "How Culture Works. Perspectives From Media Studies On the Efficacy of Symbols." Theory and Society 18:153-180.

—. (1989b). "The Sociology of News Production." Media, Culture \& Society 11:263.

-. (1992). Watergate in American Memory: How We Remember, Forget, and Reconstruct the Past. New York: Basic Books.

Schuman, Howard, Hiroko Akiyama, and Bärbel Knäuper. (1998). "Collective Memories of Germans and Japanese about the Past Half-Century.” Memory 6:427-454.

Schuman, Howard, Robert F. Belli, and Katherine Bischoping. (1997). "The Generational Basis of Historical Knowledge.” Pp. 47-78 in Collective Memory of Political Events: Social Psychological Perspectives, edited by J. W. Pennebaker, D. Páez, and B. Rimé. Mahwah, NJ: Erlbaum Associates.

Schuman, Howard and Amy D. Corning. (2000). "Collective Knowledge of Public Events: The Soviet Era from the Great Purge to Glasnost.” American Journal of Sociology 105:913956.

-. (2006). "Comparing Iraq to Vietnam - Recognition, Recall, and the Nature of Cohort Effects.” Public Opinion Quarterly 70:78-87.

Schuman, Howard and Cheryl Rieger. (1992). "Historical Analogies, Generational Effects, and Attitudes Toward War.” American Sociological Review 57:315-326.

Schuman, Howard, Cheryl Rieger, and Vladas Gaidys. (1994). "Collective Memories in the United States and Lithuania.” Pp. 313-333 in Autobiographical Memory and the Validity of Retrospective Reports, edited by N. Schwartz and S. Sudman: Springer-Verlag.

Schuman, Howard and Willard L. Rodgers. (2004). "Cohorts, Chronology, and Collective Memories.” Public Opinion Quarterly 68:217-254.

Schuman, Howard, Barry Schwartz, and Hannah D’Arcy. (2005). "Elite Revisionists and Popular Beliefs: Christopher Columbus, Hero or Villain?” Public Opinion Quarterly 69:2-29.

Schuman, Howard and Jacqueline Scott. (1989). "Generations and Collective Memories.” American Sociological Review 54:359-381.

Schuman, Howard, Vered Vinitzky-Seroussi, and Amiram D. Vinokur. (2003). "Keeping the Past Alive: Memories of Israeli Jews at the Turn of the Millennium.” Sociological Forum 18:103-136.

Schwartz, Barry. (1982). “The Social Context of Commemoration: A Study in Collective Memory.” Social Forces 61:374-402.

—. (1991). "Social Change and Collective Memory: The Democratization of George Washington.” American Sociological Review 56:221-236.

—. (1996a). "Introduction: The Expanding Past." Qualitative Sociology 19:275-282.

—. (1996b). "Memory as a Cultural System: Abraham Lincoln in World War II." American Sociological Review 61:908-927. 
—. (1998). "Postmodernity and Historical Reputation: Abraham Lincoln in Late TwentiethCentury American Memory.” Social Forces 77:63-103.

-. (2011). "From Abraham Lincoln and the Forge of American Memory." Pp. 242-248 in The Collective Memory Reader, edited by J. K. Olick, V. Vinitzky-Seroussi, and D. Levy. Oxford: Oxford University.

Schwartz, Barry and Howard Schuman. (2005). "History, Commemoration, and Belief: Abraham Lincoln in American Memory, 1945-2001.” American Sociological Review 70:183-203.

Scott, Jacqueline and Lilian Zac. (1993). "Collective memories in Britain and the United States." Public Opinion Quarterly 57:315.

Sekulić, Duško. (2004). "Civic and Ethnic Identity: The Case of Croatia.” Ethnic and Racial Studies 27:455.

Sekulić, Duško and Željka Šporer. (2007). "Vrijednosne i socijalne odrednice u ocjenjivanju povijesnih ličnosti [Value Determinants and Social Determinants in the Evaluation of Political Leaders].” Revija za sociologiju 38:3-23.

Shively, JoEllen. (1992). "Cowboys and Indians: Perceptions of Western Films Among American Indians and Anglos.” American Sociological Review 57:725-734.

Silverman, David. (2006). Interpreting Qualitative Data: Methods for Analyzing Talk, Text, and Interaction. London: Sage.

Somers, Margaret R. (1994). "The Narrative Constitution of Identity: A Relational and Network Approach.” Theory and Society 23:605-649.

Spillman, Lyn. (2003). "When Do Collective Memories Last?: Founding Moments in the United States and Australia.” Pp. 161-192 in States of Memory: Continuities, Conflicts, and Transformations in National Retrospection, edited by J. K. Olick. Durham/London: Duke University Press.

Steinmetz, George. (1992). "Reflections on the Role of Social Narratives in Working-Class Formation: Narrative Theory in the Social Sciences.” Social Science History 16:489-516.

Stets, Jan E. and Peter J. Burke. (2000). "Identity Theory and Social Identity Theory.” Social Psychology Quarterly 63:224-237.

Stryker, Sheldon and Peter J. Burke. (2000). "The Past, Present, and Future of an Identity Theory.” Social Psychology Quarterly 63:284-297.

Swidler, Ann. (1986). "Culture in Action: Symbols and Strategies.” American Sociological Review 51:273-286.

—. (2000). Talk of Love: How Culture Matters. Chicago: University of Chicago Press.

Sztompka, Piotr. (1996). "Looking Back: The Year 1989 as a Cultural and Civilizational Break." Communist \& Post-Communist Studies 29:115-129.

Teeger, Chana and Vered Vinitzky-Seroussi. (2007). "Controlling for Consensus: Commemorating Apartheid in South Africa." Symbolic Interaction 30:57-78.

Tschuggnall, Karoline and Harald Welzer. (2002). "Rewriting Memories: Family Recollections of the National Socialist Past in Germany.” Culture \& Psychology 8:130-145.

Vinitzky-Seroussi, Vered. (2002). "Commemorating a Difficult Past: Yitzhak Rabin's Memorials.” American Sociological Review:30-51.

Volkmer, Ingrid. (2006). "News in Public Memory: An International Study of Media Memories across Generations.” New York: Peter Lang Publishing.

Wagner-Pacifici, Robin and Barry Schwartz. (1991). "The Vietnam Veterans Memorial: Commemorating a Difficult Past.” American Journal of Sociology 97:376. 
Welzer, Harald. (2008). “Collateral Damage of History Education: National Socialism and the Holocaust in German Family Memory.” Social Research 75:287-314.

—. (2010). "Re-narrations: How Pasts Change in Conversational Remembering.” Memory Studies 3:5.

—. (2011). "Family Memories of World War II and the Holocaust in Europe, or Is There a European Memory?” Cultural Memories 4:171-188.

Wertsch, James V. (2002). Voices of Collective Remembering. Cambridge: Cambridge University Press.

—. (2012). "Deep Memory and Narrative Templates: Conservative Forces in Collective Memory.” Pp. 173-185 in Memory and Political Change, edited by A. Assmann and L. Shortt: Palgrave Macmillan.

Zelizer, Barbara. (1992). Covering the Body: The Kennedy Assassination, the Media, and the Shaping of Collective Memory. Chicago: University of Chicago Press.

- (1993). "Journalists as Interpretive Communities." Critical Studies in Mass Communication 10:219-237.

—. (2008). "Why Memory's Work on Journalism Does Not Reflect Journalism's Work on Memory." Memory Studies 1:79.

Zerubavel, Eviatar. (1996). “Social Memories: Steps to a Sociology of the Past.” Qualitative Sociology 19:283-299.

- (1997). Social Mindscapes. Cambridge, MA: Harvard University Press.

- (2004). Time Maps: Collective Memory and the Social Shape of the Past. Chicago: University of Chicago Press.

Zhang, Tong and Barry Schwartz. (2003). "Confucius and the Cultural Revolution: A Study in Collective Memory.” Pp. 101-127 in States of Memory: Continuities, Conflicts, and Transformations in National Retrospection, edited by J. K. Olick. Durham/London: Duke University Press. 


\section{CURRICULUM VITAE}

\section{Tanja Vuckovic Juros}

Work Address:

Dept. of Social Policy

Social Work Study Centre

University of Zagreb

Nazorova 51, Zagreb, Croatia $\quad$ E-mail: tvuckovi@indiana.edu

\section{Education}

2012 (exp.) PhD, Sociology, Indiana University at Bloomington

Dissertation: "Social Changes and the Generational Differences in the Formation of Collective Memories”

Committee: Brian Steensland (chair), Elizabeth Armstrong, Tom Gieryn, Ognjen

Čaldarović

PhD Minor: Research Methods

Qualifying Exam: Sociology of Culture (defended in June 2008)

2007 MA, Sociology, Indiana University at Bloomington

Thesis: "Old Ways in New Times. Distributive Justice Ideologies of Transitional Cohort in Four Post-communist Countries"

Committee: Brian Powell (chair), Clem Brooks

2005 BA, Sociology, English Language and Literature, University of Zagreb, Croatia

Thesis: "Tabletop Role-playing Gamers as a Subculture"

Committee: Vjekoslav Afrić (chair), Benjamin Čulig

\section{Areas of Interest}

Sociology of Culture and Subcultures, Collective Memories, Political Sociology, Sociology of Youth, Sociology of Generations, Identity Theory, Qualitative Methodology

\section{Honors and Awards}

2008 Fellowship for Doctoral Students of the National Foundation for Science, Higher Education and Technological Development of the Republic of Croatia (NZZ)

2008 Doctoral Dissertation Research Improvement Grant of the National Science Foundation (NSF), Social Behavioral and Economic Sciences (SBE) Division, Sociology Program

2008 Indiana University College of Arts \& Sciences Travel Award

2007 Doctoral Award for the Study Abroad of the Croatian Ministry for Science, Education and Sport

2005-08 Indiana University College of Arts and Science Fellowship

2005-08 Indiana University Sociology Dept. Fee Scholarship

2007-08 Indiana University Teaching Assistantship

2005-07 Indiana University Graduate Assistantship

2003 Merit Scholarship of the University of Zagreb 


\section{Publications}

Vučković Juroš, T. (2012) "Cohort and Welfare Regime Differences in Attitudes on State: Multilevel Analysis of 29 Countries”, Revija za socijalnu politiku [Social Policy Review], 19(2), available at http://hrcak.srce.hr/file/126497 [in English]

Vučković Juroš, T. (2011) "Reporting on the Issues of Research Rigour and Ethics: The Case of Publications Using Qualitative Methods in the Croatian Social Science Journals”, Revija za sociologiju [Sociological Review], 41(2), available at http://hrcak.srce.hr/file/106258 [in English]

Vučković Juroš, T. (2010) “Kako nastaju kolektivna sjećanja: Promišljanja o interakcionističkom modelu kolektivnih sjećanja" (How Collective Memories are Formed: Considering an Interactionist Model of Collective Memories), Revija za sociologiju [Sociological Review]: 40(1), available at http://hrcak.srce.hr/file/79216 [in Croatian]

Student Publications:

Vučković, T. (2003) "Role-playing Games (RPG) Subkultura” (Role-playing Games Subculture), Studentski časopis za društveno-humanističke znanosti Diskrepancija (Students' Journal for the Humanities Diskrepancija), 4(7/8)

\section{Teaching Experience}

2009-12 Teaching Assistant, Dept. of Social Policy, Social Work Study Center, University of Zagreb, Croatia Seminar Class: "Marginal Groups"

Seminar Class: "European Social Policies”

2008/09 Instructor, Dept. of Cultural Studies, Faculty of Humanities and Social Sciences, University of Rijeka, Croatia

Course: "Culture of Protest and Upheaval"

Course "Generational and Intergenerational Culture"

2007/08 Instructor, Sociology Dept., Indiana University Bloomington Course: "Subcultures and Countercultures (S101)"

2005-07 Teaching assistant, Sociology Dept., Indiana University Bloomington

TA for Brian Steensland: "Moral Controversy in American Politics (S101)"

TA for Bernice Pescosolido: "Medical Sociology (S101)"

TA for Melissa Wilde: "Introduction to Sociology (S100)"

TA for Martin Weinberg: "Constructing Sexuality (S422/S522)”

\section{Research Experience}

2008-12

Dissertation research: "Social Changes and the Generational Differences in the Formation of Collective Memories"

Full responsibility for the fieldwork consisting of 72 in-depth interviews and of the textual analysis of history textbooks and newspapers 
2006 Transcribed interviews for the research project "Constructing the Family II", project director: Brian Powell, Indiana University at Bloomington

2004-05 Participated in construction of questionnaire, co-implemented questionnaire testing for the research project "AIDS and the Young”, project director: Aleksandar Štulhofer, University of Zagreb, Croatia

2003-05 Designed and implemented online survey, conducted in-depth interviews for research for BA thesis: "Role-playing Games Subculture"

\section{Conference Presentations}

Aug. 2012 "Remembering a Failed Utopia: Reception and Interpretive Communities of Memory"

American Sociological Association Annual Meeting (Collective Memories Regular Session), Denver, USA

July 2012 "Negotiating the Mediated Past: How the Young Croatian Generations Evaluate and Appropriate the Images of the Yugoslav Past"

European Sociological Association PhD Summer School 2012 "Doing Research in the Midst of Social Change: Developing a publishing strategy”, Lisbon, Portugal

May 2012 "Intertwining of the Research Decisions and the Theoretical Foundations:

Example of a Collective Memories Study” [in Croatian]

Croatian Sociological Association Conference, Zagreb, Croatia

April 2011 "The Communist Past in the Capitalist Present. The Experiences of Two Croatian post-Yugoslav Generations"

6th InASEA Conference "Southeast European (Post) Modernities", organized by

University of Regensburg, Regensburg, Germany

April 2011 "Between Europe and the Balkans: The Croatian Cultural Identity through the Eyes of Two Young Croatian Generations" [in Croatian]

National Congress of the Croatian Sociological Society (HSD), Zagreb, Croatia

Dec. 2010 "Constructing an Interactional Model of Collective Memories Formation: The Case of Collective Memories of Yugoslavia in Post-communist Croatia"

Conference "Forms and Functions of Social Memories", organized by University of Erlangen in December 2010, Erlangen, Germany

Nov. 2010 "Reporting on Ethnographic Research in Croatian Social Sciences: Issues of Ethics and Research Rigor"

Conference "Qualitative Transitions: Issues of Methodology in Central and SouthEast European Sociologies”, organized by Croatian Sociological Society (HSD), Rijeka, Croatia

Oct. 2010 “The 'Difficult' Yugoslav Past in History Textbooks and Newspapers and the Shaping of Collective Memories"

The 2nd Young Scientists Forum on Central and South East Europe, organized by Institute for Danube Region and Central Europe (IDM), Vienna, Austria

Sept. 2010 "Social Changes and the Generational Differences in the Formation of Collective Memories"

Sociological PhD Conference, University of Zagreb, Croatia 
June 2010 "Remembering Yugoslavia in Public: The Formation of Institutionalized Collective Memories in Authoritarian and Liberal Regimes”

Joint PhD Symposium on South East Europe, organized by the London School of Economics and Political Science (LSE), University College London (UCL) i Goldsmiths University of London, London, UK.

June 2009 "Perceptions of Distributive Justice in the Postcommunist Context" Conference "Europeanization, development of Croatian social model and social cohesion”, organized by Dept. of Social Politics with Friedrich Ebert Stiftung, Zagreb, Croatia

Dec. 2008 "Persistence of Communist Ideologies in the Distributive Justice Beliefs of the Transitional Cohort in Four Post-communist Countries"

The $1^{\text {st }}$ Young Scientists Forum on Central and South East Europe, organized by Institute for Danube Region and Central Europe (IDM), Vienna, Austria

Aug. 2008 "Distributive Justice Ideologies of Transitional and Communist Cohort in Four Post-communist Countries"

ASA (American Sociological Association) Annual Meeting, Boston, MA, USA

April 2007 "Is It Fair Or Just Square? Birth Cohort Differences in the Perception of Social Justice in Post-communist Countries"

MSS/NCSA Joint Annual Meeting, Chicago, IL, USA

June 2002 "Social Perception of Justice"

Conference "Social Structures and Institutions: The Quest for Social Justice", Inter-University Centre, Dubrovnik, Croatia

\section{Workshops}

June 2010

May 2010

Oct. 2008 2nd European Values Study Workshop, Faculty of Law, University of Zagreb

"Communication in Science - Writing and Speaking about Your Research", University of Zagreb, Croatia

"Introduction to Atlas.ti” (qualitative data analysis software), SdG Associates, London, UK

\section{Service}

2011-current Member of the Presidency of the Croatian Sociological Society (HSD)

2011-current Co-initiator and the secretary of the Section for Qualitative Research Methods at the Croatian Sociological Society

2009 Reviewer for Revija za socijalnu politiku (Social Politics Review), Zagreb, Croatia

Oct. 2009 Invited lecture “The Tabletop Role-Playing Gamers as a Subculture” at the Science Fiction, Fantasy \& Horror Convention Rikon, Rijeka, Croatia

March 2007 Moderator at Undergraduate Research Fair organized by Hutton Honors College, Indiana University at Bloomington

2006, 2007 Panelist at the Undergraduate Orientation for Teaching Abroad organized by the School of Education, Indiana University at Bloomington

2003-05 Member of the editorial board of the Students' Journal for the Humanities Diskrepancija, University of Zagreb, Croatia

2004 Editor of the 2005 Croatian edition of Runaway World by A. Giddens, published by Jesenski i Turk

2003/04 Vice-president, Sociology Students' Club “Diskrepancija”, University of Zagreb 


\section{Professional Memberships}

2012 European Sociological Association (ESA)

2007-12 American Sociological Association (ASA)

2008-12 Croatian Sociological Society (HSD)

\section{REFERENCES PROVIDED AT REQUEST.}

